REMINGTON KELLLOGG LIBRARY OF

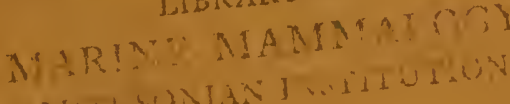

\title{
The
}

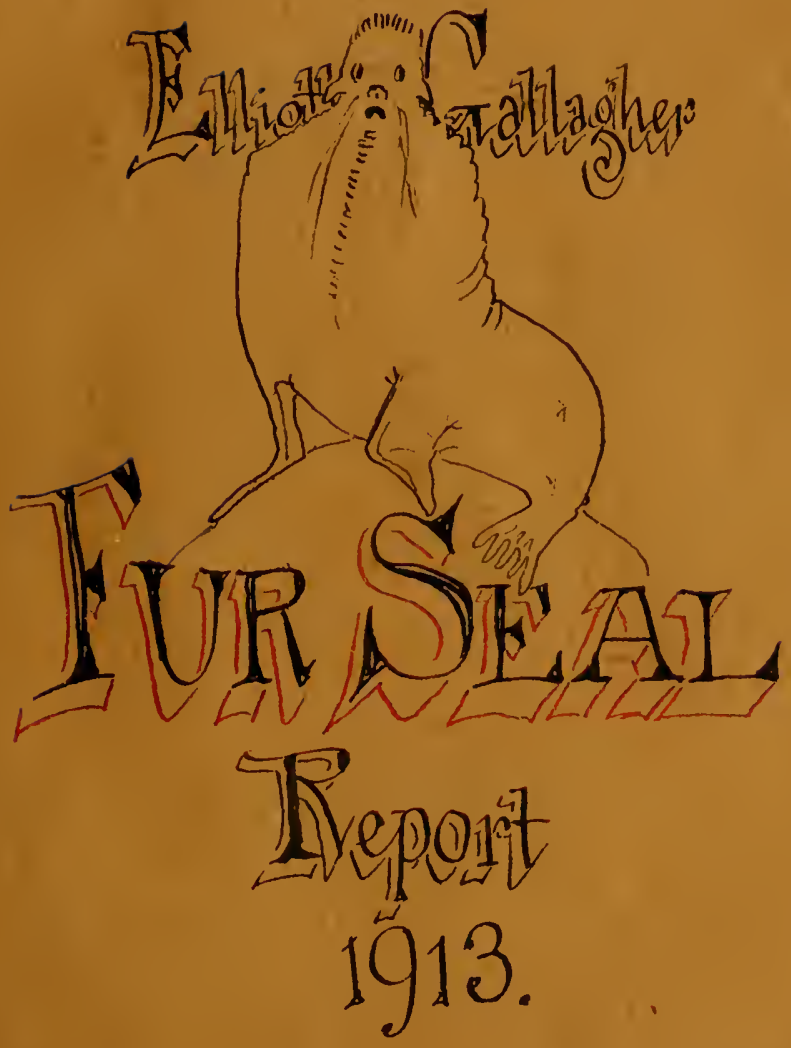

is.

Mitu Jordan-Alejiceser foldenda 



\section{THE REPORT}

OF THE SPECIAL AGENTS OF THE HOUSE COMMITTEE ON EXPENDITURES IN THE DEPARTMENT

OF COMMERCE

UPON THE

\section{CONDITION OF THE FUR-SEAL HERD}

\section{OF ALASKA AND THE CONDUCT}

OF THE PUBLIC BUSINESS ON

\section{THE PRIBILOF ISLANDS}

AS ORDERED BY THE COMMITTEE. JUNE. 20, 1913

AND MADE BY THE SAID AGENTS, AUGUST 31, 1913

$S \mid 1$

301

TO THE CHAIRMAN

HON. J. H. ROTHERMEL

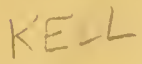

By

HENRY W. ELLIOTT

AND

ANDREW F. GALLAGHER

Agents of Committee

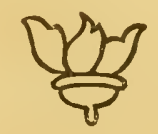




\section{EXHIBIT F.}

[See pp. 61, 62 of the Fur Trade Review, New Iork, issue of Feb., 1911; received at the Congressional Library Feb. $7,1911$.

Here is the official return made to the Secretary of Commerce and Labor December 17, 1910 , of the sale of 12,920 fur-seal skins taken on the Pribilof Islands during June and July, 1910, out of which 8,000 skins are the skins of yearling fur seals, all deliberately and knowingly taken in gross violation of the Hitchcock rules of May 1, 1904, and all of which skins are again falsely certified to the department as legally taken and "not under 2 years of age"; this done by United States Fish Commissioner Bowers and his subordinate agents on the seal islands of Alaska.

[Memorandum.]

FLAYS UNITED STATES SEAL POLICY-ZOOLOGIST TELLS SENATE COMMITTEE METHODS IN VOGUE PRODUCE ONLY WEAKLINGS.

iT Ashington, February 4, 1910.-An attack upon the Government's policy in caring for fur seals upon the Pribilof Islands in Alaska was made to-day by Dr. William T. Hornaday, of the New York Zoological Gardens, and Prof. H. IV. Elliott. They spoke for the Campfire Club of America before the Senate Committee on Conservation of National Resources.

The speakers declared that under the act of last year, which eanceled the lease theretofore held by the North American Commercial Co. and gave control of the killing of fur seals to the Secretary of Commerce and Labor, there had been no cessation of wanton killing.

Dr. Hornaday condemned the policy of weeding out the males when they are babies, leaving only such number as was needed for breeding purposes. He declared that the system left weaklings. (Cleveland (Ohio) Plain Dealer, Feb. 5, 1911.)

[A memorandum for Senator Heyburn in re i]legal and injurious killing of fur seals on the Pribilof Islands, and falsely certified to the Government as proper and legal by its own sworn agents thereon.]

Saturday, February 4, before the Committee on Conservation of National Resources, Secretary Nagel appeared, and his agent in charge of the seal islands, W. I. Lembkey, made a statement to justify the killing of seals on those islands, as ordered by the Secretary last season and prior to that.

Mr. Lembkey's statement, stripped of verbiage, was in effect that-

I. He killed no seals under 2 years of age.

II. He killed no females.

III. He saved 5 per cent of the male 2 and 3 year olds; killed 95 per cent.

Each and every one of those statements is absolutely untrue, for-

I. He did kill more than 10,000 seals (out of the 12,920 which he took) which were under 2 years of age, and the London records of the sale, December 16 last, if produced, will declare it.

II. He did kill females, therefore, since at least one-third, if not quite one-half of the 10,000 "long yearlings" and "short 2-year-olds," which he killed last season, were females-since the yearlings haul out in equal numbers, males and females together, and are absolutely alike to all out ward form, size, and color. (Lembkey admitted that. He also admitted that he could not tell the skins apart when removed from the bodies as to sex. He also admitted that there was no penalty ever inflicted for killing female seals.)

Mr. Lembkey was confronted with the proof that he did not even spare the 5 per cent "saved" 2 and 3 year old male seals, but so managed this job that aiter "sparing" them in June and July he killed them in October and November following, for "the natives' food!" He did not attempt to deny this proof; he could not; it was officially made.

Henry W. Elliott. 


\section{FUR-SEAL HERD OF ALASKA.}

\section{Committee on Expenditures ix the}

Departilent of Commerce,

House of Representatives,

Washington, D. C., June 20, 1913.

The committee met at 10.30 a $\mathrm{m}$., Hon. John H. Rothermel, chaiman, presiding.

Present: Hon. John H. Stevens, Hon. John T. Watkins, and Hon. Charles E. Patton.

The Chammax. The meeting this morning is called for the purpose of organizing the committee and for the purpose of submitting the proposition of engaging certain persons to visit the Pribilof Islands.

On motion of Hon. John H. Stevens, the chairman was authorized to select a clerk of the committee.

On motion of Hon. John T. Watkins, the following resolution was adopted:

Ordered, That Henry W. Elliott is hereby appointerl as a duly qualified expert to gather certain information touching the conduct of public affairs on the seal islands of Alaska as the chairman of the committee shall require, and that Andrew F. Gallagher is hereby appointed as a duly qualified expert stenographer and notary to accompany Mr. Elliott and record the details of that information as it shall be developed under the instructions of the chairman.

On the adoption of the resolution the vote was as follows:

Ayes, Hon. John H. Stevens and Hon. John T. Watkins; noes, Hon. Charles E. Patton.

There was no further business to transact, consequently the committee adjourned at $11.10 \mathrm{a} . \mathrm{m}$. to reconvene at the call of the chairman.

\section{REPORT OF THE SPECIAL AGENTS.}

Hon. John H. Rothermei,

$$
\text { Washington, D. C., August 31, } 1913 .
$$

\section{Chairman House Committee on}

Expenditures in Department of Commerce,

House of Representatives, Washington, D. C.

SiR: On the 21st of last June we received from your hands our appointment as special agents of your committee duly authorized by its action on that day. Your letter of notice ordered us to proceed without delay to the seal islands of Alaska by the most direct 
route and make a thorough examination into the condition of the fur-seal herd thereon as we should find it and into all details of the conduct of the public business thereon since May 1, 1890, up to date.

We therefore proceeded direct to Seattle, Wash., and took passage on the Nome steamer Victoria, which sailed July 1, $3.40 \mathrm{p}$. m. As this vessel never stops at the seal islands, through the kindness of the Secretary of the Treasury we were met in Onimak Pass on July 7 last and taken on board the United States revenue cutter Tahoma, Capt. Chiswell, who landed us at St. Paul Island on July S last.

Agrecably to our instructions, we at once look up and finished the following subjects of direct personal study and investigation:

I. July 10 to 20 - A personal survey was made of every one of the 17 breeding grounds or "rookeries" of the fur seals on St. George and St. Paul Islands. We looked into erery harem, and made as reasonable and accurate a count of the bulls and cows thorein as men of common selise can make. The found this herd to-day is so far depleted from its form of 1872 , and then of 1890 , thit the same mothods of enumeration, which must be used as they were used then, by Mr. Elliott, when there were 4,700,000 and then later 1,000,000 seals, conld not be employed; so, a careful estimate and counting of the adult breeding seals in cach harem, when they were not "massed," was made by us, and it gives the following figures and

(a) Has ileveloped the fact that only a minute fraction of the promer number of young bulls were seen on the brecding grounds, and that the old buils thereon wore so few and far between that they often had harems of 10()$_{10}$ 120 females; that the arepage harem was at least 55 cows, ${ }^{2}$ instead of heing 2() , which is the normal number when the herel is in its best form.

(b) This situation un there, as above stated, makes the (ase fairly desperate, and it would speedily result in the complete extemination of the nuale lreeding life of these Pribilof preserves and "rookeries" if it were not for the rlose time now ordered by law of August 24, 1912, which forees a total suspension of all killing of young male seals on the islands, exeret for the food of natives, cluring the next five years.

(c) There are some 56,000 cows on the St. Paul breeding grounds and about 16,000 on St. (reorge, or 72,000 juy)ping rows this season of 1913. 'To this number we may sifely add some 7.000 nubiles, making in all about 80,000 cows for this year of 1913 . The 72,000 pups of 1913 (less about 2 per cent cleath rate for natural causes), or 70,000 pups in round numbers, and some 1,400 old bulls, with less

1 We gave the subject of the "counting" of "live pups" with a view to getting a fair idea of its sense and accuracy in determining the numbers of breeding seals on these Pribilof rookeries very close attention. A careful study of the work as it has been dome on St. George aud St. Paul Islands, beginning in 1901 and ending in 1912, warrants our statement that it is not an accurate census when said to be so made. It is an estimate only, and one that is arrived at by making a highly injurious disturbance on the breeding grounds; it should be prohiluited as jdle and positively detrimental. The umanimous objection of the natives to this job of "counting" live pups as one of the chief causes of injury to the herd is expressed in detail. (See Exhibit E postea.)

'That the inen who have oflicially done this work of "counting live' pups for an "accurate" census since 1901 to date do not believe in it, and think it is inaccurate and should be stopped, is well exhibited by copies of their entries made officially in the journals of St. George and St. Paul. Some of these we submit in proof of the above, as Exhibit $\mathrm{F}$ yostea.

( 2 This average is misleading, in fact, though it is the only figure which can le used, unless it is qualified as follows: For instance, take a series of harems on the reef, between stations $F$ and $\mathrm{E}$; here there are 25; 1 bull has 200 cow s, 6 bulls have each niore than 100,3 bulls have each 50,10 bulls have from 12 to 25 cows each, 3 bulls only 2 cows, and 2 bulls have none; this 25 bulls, 1,136 cows, or average of 45 cows to a bull. That is, in truth, not so. There are 10 luuls with 1,050 cows, or 100 cows each, while the other 15 bulls have but 186 cows between them. As they lo not meddle with any cows except as liauled out in their respective harens, the average distribution of service, at 45 cows to the bull, is wholly misleading. 
than 150 young bulls make up the following sum total of the breeding strength of the fur-seal herd for this season of 1913, to wit:

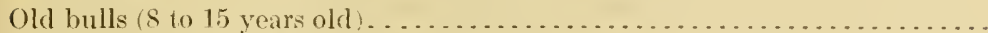

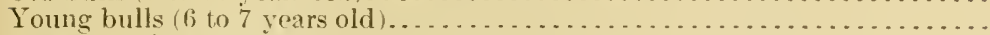

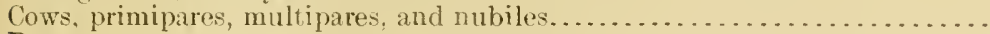

Pups, . . . . . . . . . . . . . . . . . . . . . . . . . . . . . . . . .

Total $\left(\delta^{x}, q\right.$, and

Then add (a vague estimate):

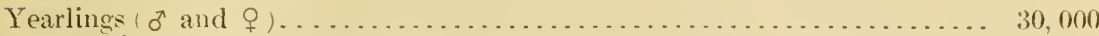

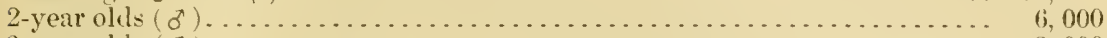

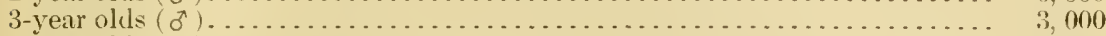

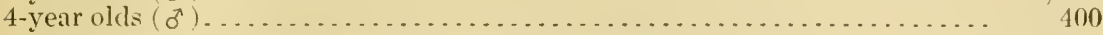

Frand total seals $(\delta, f$, and $o$, season of 1913$) \ldots \ldots \ldots \ldots \ldots \ldots . \overline{190,950}$

Table showing the relative size of the fur-seal herd of 1913 when contrasted with its form in 1874 and $1890 .{ }^{1}$

\begin{tabular}{|c|c|c|c|c|c|c|}
\hline Years. & $\begin{array}{l}\text { Old } \\
\text { bulls. }\end{array}$ & $\begin{array}{l}\text { Young } \\
\text { billis. }\end{array}$ & $\begin{array}{c}\text { Cows- } \\
\text { nubiles, pri- } \\
\text { nuipares, } \\
\text { and multi- } \\
\text { pares. }\end{array}$ & Pups. & $\begin{array}{l}\text { Grand } \\
\text { total. }\end{array}$ & Remarks. \\
\hline 1874 & 90,000 & 30,000 & $1,60 \mathrm{~s}, 040$ & $1,300,000$ & $3,028,040$ & \\
\hline 1890 & 11,000 & 500 & $4 \checkmark 0,000$ & $+60,000$ & 951,500 & $\begin{array}{l}\text { Or only one-third of the } 1874 \text { herd of } \\
\text { breeding seals and yoltng. }\end{array}$ \\
\hline 1913 & 1,400 & 150 & 80,000 & 70,000 & 151,550 & $\begin{array}{l}\text { Or only one-twentieth of the } 1874 \text { herd of } \\
\text { breeding seals and young. }\end{array}$ \\
\hline
\end{tabular}

1 The nonbreeding yearlings and 2,3,4, and 5 year old males are not included in this table, since they can not be reasonably estimated for (during the last 20 years); they had practically disappeared from the island grounds when looked for in 1913.

NotE.-These figures declare the fact that the decrease from 1874 to 1890 was a loss of two-thirds of this herd's breeding strength.

Then, they declare the fact that that decrease from 1890 to 1913 shows clearly that the herd has suffered a loss of five-sixtli of its breeding strength during this interval and is close to the verge of complete destruction of its virile male life- nuless it is fully shielded from killing on the islands and the sea for a term of years ahead.

(See detailed discussion and figures, in Exhibit $\Lambda$, postea.)

II. July $21-\Lambda$ careful examination was made of the official seal island agent's journals, or "'log books," as kept in the oflice of the United States agents on St. Paul Island, from 1890 to date.

1 That serious matter of the lack of breeding bulls, or of the utter absence of surplus or young virile mitle life on the rookeries, during this season of 1913, makes the following statement, given to IIon. E. WW. Townsend by George A. Clark, under date of Feb. 28, 1913, significant, since he has declared that "the coudition of the herd to-day is an ideal one."

"Stanford Uiniversity, California, February 281913.

"DEAR SiR: * * * I was on the Pribilof Islands dıring the season of 1496-97, under Dr. Jordal1, and participated actively in the work of investigation, in addition to having the benefit of all the training and experience of the other members of the commission. I did the actual work of counting, and know that there were three idle and young bulls for every bull in active service on the rookeries in those seasons. * * * I was again on the islands in 1909 , and again counted the bulls-one idle or reserve bull for each two in service. $* * *$ I visited the islands again last stummer (1912) and found conditions as they were in 1909. These are facts, not conjectures and opinions. ****

Every bull engaged this summer (1913) was earefully located and counted by us. We found just 1,450 so engaged with 80,000 cows. We found less than 150 "reserve" or "idle" bulls.

Now, if George A. Clark is telling the truth to Hon. E. W. Townsend, this "reserve of one bull idle for every two in service" during 1912 has suddenly disappeared. There is to-day actually less than one idle or reserve bull for every nine in service.

This is a sudden and a dangerous collapse of the virile breeting male life on the rookeries since 1912 if Clark is telling the truth. 
(a) This work discloses the fact that in this official journal (p. 14) under date of June 17, 1896, is a certified copy of the order of the Secretary of the Treasury, dated "May 14, 1896," which prohibits "the killing of yearlings, and seals having skins weighing less than 6 pounds." "This order which was published then to the agents of the government and the lessees, was actually violated and ignored that very season of 1896 ; and also carefully suppressed from the notice of the House Committee on Expenditures in the Department of Commerce and Labor by the officials of the Bureau of Fisheries when interrogated May 31-July 30, 1911, and February 29-July 31, 1912, as to what rules and regulations had been ordered by the departments in charge of the seal herd prior to and since $1890 .^{1}$ It also appears from a careful examination of this official journal above cited, that no order of change to those "Carlisle rules" of May 14, 1896, has ever been made by any Secretary of the Treasury or Commerce and Labor, until Secretary Metealf, in 1906, was persuaded to make a "5-pound" minimum limit, and thus make it easier for the lessees to nullify the "Hitcheock rules" of May 1, 1904, which pre-

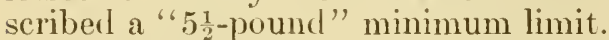

(For full details and proof of this violation by the lessees of the regulations of 1896 , up to (late of 1906 , see Exhibit B, postea.)

(b) It also further discloses the fact that the sealing schooner Fate and Anna, which C. H. Townsend, of, and "expert" of, the United States Bureau of Fisheries, and H. H. D. Pierce, as the Third Assistant Secretary of State, rouched for as a proper claimant for damages agrainst Russia, in 1902, at the Hague, was, in fact, a pirate, and busy in raiding our Pribilof herd during the summer of 1890 . (For full details see Exhibit C, postea.)

III. July 22. A careful survey was made of the natives' houses on St. Paul and St. George and the condition of the same, as well as other inquiries touching the same. They were found to be in fairly good condition, requiring minor repairs only, many of them without any need of attention. The natives, 302 of them, all told, are fairly well provicled for. (For full details see Exhibit D, postea.)

IV. July 23 to 25.-A careful examination was made of the Seal Island natives who hare killed the seals for the lessees during the last 20 years under orders of the United States agents - the drives, how made, the ages or classes of seals killed, etc. Their answers were taken down, then translated to them as taken down, and approved by them in writing after they had been read by the interpreter to them in Aleut, which is their own language and used by them among themselves. (For full details see Exhibit E, postea.)

V. July 29. 1913.-The salt-cured skins of 400 seals killed under direction of United States Special Agent Lembkey, July 7, 1913, were all carefully measured and then weighed by us July 29 following, as they were salted and bundled for shipment to London. These skins were all tagged and numbered by Mr. Lembkey on July 7,1913 ,

1 The following sworn statement of untruth is made by the Bureau of Fisheries, to wit:

Dr. EVERMANN. * * * In answer to this charge it should be sufficient to say that the law has never made it illegal to kill yearling male seals; nor has it ever been contrary to the regulations to kill yearling male seals, exeept in the seasons of 1904 and 1905 , as is shown by the regulations for the various years to whieh 1 have called your attention. Therefore, even if 129,478 jearling male seals have been killed since 1899 (whieh is not admitted) they could not have been killed illegally, beeause there was no law against killing yearling male seals, and there has been no regulations against killing yearling male seals, except in 1904 to 1909. (Hearing No. 10, p. 493, Apr. 19, 1912, House Committee on Expenditures in the Department of Comnierce and Labor.) 
and their "green" weights recorded then by him before salting on that day.

We took this list of tagged skins and numbers, and measured them for their sizes, and then reweighed them in the salt. It became clear, as this work progressed, that the small 31-34 inch skins were so "loaded" with blubber that they actually weighed as much as the large 40-43 inch skins, which were not loaded-never loaded; so that without these measurement checks upon them, those little yearling skins (30-34 inch skins) - appeared in this list of "green" weights as well as or as heary as the large, or 40-43 inch skins.

This aecounts for the fierce insistence of the officials of the Burean of Fisheries that their 6-pound and 7-pound skin weights were proof of the fact that they were not "yearlings"-were "2-year-o]d" seals. This insistence they kept up until it was at last extorted from them that the measurement of the skin alone declared its real size or age. On page 446, Hearing No. 9, April 13, 1912, House Committee on Expenditures in the Department of Commerce and Labor, the following sworn statement is made by Mr. Lembkey, who is the same man that ordered and directed the killing and skinning of these 400 seals on July 7 last, which we handled July 29 following:

Mr. Elliott. Mr. Lembkey. you say you never have weighed these skins aiter you have salted them? You have never weighed them?

Mr. LEMBKEY. I have never weighed them after the salting on the islands; no, sir.

Mr. Elliotr. Have you ever issued any orders or heard any orders issued to have more or less blubber taken?

Mr. LembKeY. Never.

Mr. Elliotr. Is it not true that a native can skin a $4 \frac{1}{2}$-pound skin off and add blukber to it so as to make it weight 5 pounds?

Mr. LEMB KEY. It certainly is. ${ }^{1}$

Mr. Elliott. Would it destroy the value of that skin if he did?

Mr. Lembiey. Not in the least, except that it would require longer to salt.

Mr. ElLiotT. And it would absorb more salt, would it not?

Mr. LEMBKEY. I think so: yes.

Mr. Et.Liott. And that would add very much to the weight of the $1 \frac{1}{2}$-pound skin?

Mr. LEMBKEy. Yes: the blubber would.

Mr. Ellotot. All that can be done, can it not?

Ir. LEMBKEY. I might state here, while you are on that point, that it would not alter, except in perhaps a very slight degree, the classification of that skin when it. was received in London by the factors.

Mr. Elliott' Certainly.

Mr. LEMBKEY. You might make a rearling skin weigh 9 pounds by the adding of blubber. ${ }^{2}$ yet when it got to London it would be only so long and so wide.

Mr. ElciotT. That is it.

Mr. LEMBkey. And of course it would develop in the classification when the skins would be exposed for sale.

Here Mr. Lembkey (who has directed all of the island killing of seals for the lessees since 1899 , and up to date of July 7,1913 ) tells the committee that he has never issued any orders to have more or less blubber taken, yet here are 400 skins under our eyes which were all taken under his personal direction, July 7 last (1913), and nearly every small skin is "loaded" with blubber so hearily that it weighs as much as the larger skins, which, in turn, are all "clean skinned," and so weigh near to their real size. ${ }^{2}$

\footnotetext{
(1 See native sealers' statements that they were told to leave blubber on these "small" skins. (Exhibit E, ) postea.)

$\left\{\begin{array}{l}2 \text { See native sealers' statements, who say they were ordered to leave this extra blubber on "small" skins } \\ \text { in 1896, and have done so up to date. (Exhibit E, postea.) }\end{array}\right.$
} 
This orderly "loading" of every smal! skin and "unloading" of every large skin, so as to make them weigh all as large skins, is a mere accident, is it? No. ${ }^{1}$ (The details of this exposure of that "loading" of the "eyeplaster" 30-34 inch skins, so as to make them weigh into the real weights of the 2 and 3 year old or "prime " skins, are furnished in full by the Exhibit F, which follows:)

This public measurement and weighing of those salted skins also shows clearly and indisputably that the British and American contention that "salting increases the weight of the 'green' or freshtaken skins" "is right; that it does not send them lighter, when so salted, to London than when "green" and first put into salt; and still further, this record as put out in Exhibit F, postea, fully bears out the following testimony as given in hearing No. 1, page 14, House Committee on Expenditures in the Department of Commerce and Labor, May 31, 1911:

Mr. ElLiotr. I will go further and submit, as Exhibit J, this paper. I won't read all of this in regard to the British authority on Alaskan fur-seal classification and what he says as compared with our tables, but I will read one word from a chief British authority in an official letter written December 21, 1892, by Sir Curtis Lampson's sons to the British commissioners, Sir George Baden-Powell and Dr. George M. Dawson. Sir Curtis Lampson says:

We are unable to answer your inquiry as to in what class in the sales catalogue would be placed a skin classified on the islands as, say, a 7-pound skin, as we do not know whether the classification you mention refers to the skins as taken from the animals, or after they have been cured and salted ready for shipment. The process of curing and salting must of necessity add to the weight. (See p. 916; Proceedings of the Tribumal of Arbitration, vol. 8, Paris, 1893.)

Now, let me tell you that the salt addled in curing a $4 \frac{1}{2}$-pound "green" yearling skin will increase its weight to 5 pounds, or even to $5 \frac{1}{2}$ pounds, according to the amount of salt used.

Now, you will understand why a "5-pound" skin can not be taken on the islands and honestly, truthfully certified to Mr. Nagel's books as a skin "not under 2 years of age," because a 2-year-old skin weighs, with the same treatment that this skin has received, a minimum of 6 pounds. A small "runt" 2 years old may weigh $5 \frac{1}{2}$ pounds. I have seen "runts" that would not weigh 5 pounds; but we are not dealing with exceptions. We are dealing with broad, square averages. I am willing to admit that a few exceptions can be found. I am willing to admit that a man might knock down a "long" yearling here and there; but when he deliberately says to Mr. Nagel that a 5 -pound skin is a 2-year-old seal, I will take him to the seals themselves, and they will confound him; and you gentlemen can easily go with me. I would like to submit this as an exhibit.

Mr. McGilicuodr. Professor, these classifications here are before they are salted?

Mr. Elliott. Yes, sir; they are "green" skins.

Mr. MCGILlicudDr. Just as they are taken from the body:"

Mr. Ellotot. Yes: and the London classifications are of salted skins.

1 The sworn statements of United States Commissioner of Fisheries Bowers and Chief Special Agent Lembkey, as below, that these "loaded" skins are classified and sold by weight (which are and were made
to deceive the committee), to wit:

Mr. LEMBKEY. These skins which were sent to London during the years 1909 and 1910 were weighed by the factors after their arrival in London and the weights found to correspond with those taken on the island. As this factor, Lampson \& Co., is essentially a disinterested person, being concern ed not the least with the question of weights or regulations, but wholly with the salc of the skins and the payments therefor, their verification of these weights may be taken as conclusive of their accuracy.

So far, therefore, as concerns compliance with the regulations and the law in the killing of male seals, no malfeasanc e can be proven, because not only the records of the department but the weights of the same skins in $\mathrm{L}$ ondon, taken by an independent and responsible body of experts, prove that the limits of weight laid down by the instructions of the department have been complied with as closely as it is possible for human ag ency to do so. The weights of skins taken on the islands show this, and furthermore these weights have been verified in London by an independent and responsible body of men. (Hearing No. 9 ,

pp. $37.4-375$, A pr. 13, 1912, House Committee on Expenditures in the Department of Commerce and Labor.

Mr. PA TTON. You mean it is a report that is sworn to by the people who do the selling in London?

Mr. BO WERS. No, sir; it is the classification of the London merchants who sell the skins for the United States Government.

Mr. PA TTON. And they pay on that weight?

Mr. E LLIOTT. Right there l want tointer. Their classification is made on those weights.

Mr. E LLIOTT. Right there 1 want to interpose the statement that they do not weigh those skins to classify
them. They measure them. the Department of Commerce and Labor.) 
VI. July 30-31.-The subject of the best and most economic plan or system of purchasing and distributing supplies for the seal islands, the patrol fleet. which guards them, together with the wireless stations of the Navy established on them, as well as for all the lighthouses of the Department of Commerce, in Alaska, for the Alaska teachers and schools of the Department of the Interior, and general mail service outside of the limited lines of contract on Bering Seathis important subject was carefully studied by us. We find that an annual saving of about $\$ 100,000$ will result if the following plan is adopted:

(a) There should be a single United States transport ship, capable of carrying 1,000 to 1,500 tons of freight, which could and would bring up all the coal, food supplies, oil, gasoline, hardware, etc., and every article required by these Government stations to one common depot in Bering Sea for distribution therefrom to the various sealisland stations, the lighthouse points, the Fisheries Bureau, the Bureau of Education, and the United States Revenue-Cutter Service in the waters of Bering Sea, the Arctic Ocean, and the North Pacific, and that depot should be located at the Dutch Harbor, Unalaska Island, as the most central and best fitted port.

(b) This owning and use of such a Government transport ship would enable the Gorernment to purchase coal in the best markets at wholesale rates and then put it in a large "bulk pile" at Dutch Harbor at just half the cost per ton which it is now compelled to pay for coaling the several Alaskan stations of the wireless, of the lighthouses, of the seal islands, and the United States RevenueCutter Service on patrol duty in those waters.

(c) This depot of supplies could and should be placed entirely under the control of the United States Revenuc-Cutter Service, which could and would distribute all of those supplies by that transport ship aforesaid without adding a single man to the public pay roll. It would do that work promptly and most efficiently on the several requisitions of the Nary, Treasury, Commerce, Interior, Post Office, and Department of Justice authorities.

(d) This Government transport ship aforesaid could and would bring in bulk all of those stores and supplies such as coal, live cattle, sheep, foodstuffs, clothing, etc., and discharge them in bulk at this central depot; then in turn could distribute them from her declis to those several Govermment stations aforesaid, and also receive and transport such persons as may be designated. As it is now done, it is in a most irregular manner to a vastly greater cost and extreme disadvantage to the Government under the present system, due to lack of united or full concert of action by the several departments above cited.

(e) The United States Navy has large supply stations at Bremerton, Wash., and Mare Island, Cal. They purchase their supplies in large quantities at wholesale rates, and which supplies are stored there, and these are precisely such supplies as are needed and used to-day in the scveral Alaskan Government stations as stated above.

Then should any additional supplies be needed for the Alaskan service, they could and would be easily purchased by those naval buyers at the same reduced rates which they obtain for their other stores. 
The single item of coal, if a coal pile at Dutch Harbor were established as above described, would result in an annual saving to the Government of more than $\$ 70,000$ per annum.

This saving on all items of Alaskan Government supplies annually would not be less than $\$ 100,000$ per annum over the present chaotic system of purchase and distribution.

We submit the foregoing statements of fact, with the several exhibits of specific detail, as itemized above, to you, as our report made in obedience to your letter of instruction, dated June 21 last. Tery respectfully,

Henry W. Elliotto. A. F. Gallagher. 


\section{EXHIBIT A.}

Part 1.

Specific details of the fur-seal census of 1913, made by Henly W. Elliott and A. F. Gallagher, special agents of the House Committee on Expenditures in the Department of Commerce, July 10-20, 1913, on the Pribilof rookelies of the seal islands of Alaska, giving the facts and figures in detail, with charts of the 17 breeding grounds or rookeries on St. Paul and St. George Islands, with a résumé of the fur-seal census of $1872-1874,1890$, as to details of their making, in contrast with the work of the Jordan Commission of 1896-1S98, and the census work of the Bureau of Fisheries up to date of 1912 .

THE FUR-SEAL CENSUS, 1890 TO DATE, 1913, SEAL ISLANDS OF ALASKA.

Our survey of the fur-seal herd this season (July 10-20, 1913) has clearly proved the error of the Jordan-Thompson Commission's census of 1S96-97. That census in Dr. Jordan's final report (p. 79 et seq., Fur-Seal Investigations, 1S96-97, Part I) gave only 376,000 seals of all classes to this herd as existing then (season of 1896-97) upon the rookeries and hauling grounds of the Pribilof Islands.

Upon the basis of that erroneous sum total, all of the statements annually issued by the Bureau of Fisheries since then, up to 1912, have been made. The steady killing by the pelagic sealer and the lessees annually had made no greater imroad upon that "scientific" herd of 376,000 seals of 1897 than to leave by August 1, 1912, the sum total of " 215,000 seals of all classes." "This is Jordan's last census, i. e., 165,352, breeding seals and young, and some 40,000 non breeding seals.)

The manifest error of this census of the Jordan commission for $1897^{1}$ is at once apparent when a careful review of the killing on land and in the sea is made from 1897 to date of 1912 , as above. The manifest truth of the Elliott survey of that herd in 1890 is also fully declared by this House committee's survey of 1913, in which 190,950 seals of all classes are found to be in existence on the Pribilof rookeries and hauling grounds. Elliott, in 1890, summed up the total of the brecding Pribilof seals and young at 959,393, or a "scant million," as against 3,193,420 such seals in 1874 (p. 57, H. Doc. No. 175, 54 th Cong., 1st sess), and against some 1,250,000 nonbreeding seals in 1874 he found in 1890 some 80,000 only. (See H. Doc. No. 175, 54 th Cong., 1st sess., pp. 57, 58.)

I The following extract from a report upon the condition of the fur-seal herd in 1909, made by Chief Special Agent Lembkey, shows that he was unable to agree with Dr. Jordan's census work, which latter had published as the "first accurate count ever made."

Yet, in spite of this full understanding of its error, as given below by Lembkey, that erroneous census of Jordan was used as the foundation of all succeeding work b5 Lembkey from 1904 to 1911:

in 1897 the investigation made by the commission of which Dr. David Starr Jordan was chief disclosed a ratio of bachelors to the whole herd of 1 to 20 . That ratio was used by him in his criticisms of the accuracy of H. W. Elliott's censuses based on acreage measurements in 1874 and 1890 . Subsequently, as stated in Mr. E. W. Sims's report on the seal islands, in 1906, the relation of bachelors to the whole herd in 1904 and 1905, according to the censuses made by the agent in charge of seal fisheries for those years, was found to be, respectively, 1 to 16 and 1 to 14 .

In 1909 , by such methods of computation as are available, the whole herd of seals numbered approximately 133,000 , while the catch of bachelors was 14,331. Idded to the latter, to form an idea of the total bachelor yield of the herd, should be 2,000 bachelors marked and released, making a total possible catch of bachelors for 1909 of 16,331 . When we contrast this yield of bachelors for 1909 with the number of the whole herd in 
This survey of 1890 , which declared at least $1,000,000$ seals to be in existence then on the Pribilof Island rookeries, was approved by the Joint Anglo-American Commission of 1891, and not disputed by it. But, when Dr. Jordan came upon the ground in 1896-97, he, and his associates, declared Elliott's work of 1890 to be "even worse in its error than his survey of 1874"; Dr. Jordan then published an "accurate census of this herd"-.." the first," ever, at which he left it in 1897, being less in sum total than 380,000 seals of all classes.

When Elliott closed his survey of 1890, August 1, only 16,000 seals had been killed on the Pribilof Islands, and the pelagic hunters had taken from this herd during the entire season of 1890 only 25,746 seals. Then in 1S91, 1S92, and 1893 following the modus vivendi operated, which reduced the killing on the islands to less than 30,000 seals during that period and entirely eliminated the killing in Bering Sea around those islands by the Canadian and American pelagic fleet, which crossed over and fell upon the Russian herd.

In 1894 the lessees were permitted to kill 15,000 seals; and again in 1895 the same; while this pelagic fleet resumed its work in Bering Sea, getting at least during 1894-1896 the equivalent of some 200,000 seals from our herd. So, when Dir. Jordan came upon this ground in 1596, there must have been fully as many seals in existence then as when Elliott riewed them in 1890 . 'These animals had been spared from harsh killing on land and in the sea, from 1890 to 1894, so that they had at least held their own, while the killing of 1894 and 1895 had not cut them down much more than 100,000 below the figures of 1890 , which were about 1,000,000 males, females, and young, in round numbers.

that year, we have a relation of bachelors to the whole herd of 1 to 9 . The following table will show the various ratios for the years mentioned:

Ratio of bachelors in certain years.

\begin{tabular}{|c|c|c|c|c|}
\hline Year. & $\begin{array}{c}\text { Bachclors } \\
\text { killod. }\end{array}$ & $\begin{array}{l}\text { Whole } \\
\text { herd. }\end{array}$ & $\begin{array}{l}\text { Bachelors } \\
\text { released. }\end{array}$ & $\begin{array}{l}\text { Ratio of } \\
\text { cateh to } \\
\text { whole herd. }\end{array}$ \\
\hline 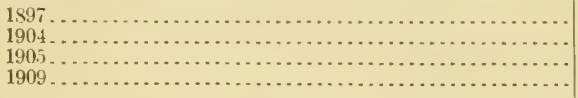 & $\begin{array}{l}20,766 \\
13,128 \\
14,368 \\
14,331\end{array}$ & $\begin{array}{l}402,850 \\
243,103 \\
223,009 \\
133,000\end{array}$ & $\begin{array}{l}2,054 \\
2,171 \\
2,000\end{array}$ & $\begin{array}{l}1 \text { to } 20 . \\
1 \text { to } 16 \\
1 \text { to } 14 \\
1 \text { to } 9 .\end{array}$ \\
\hline
\end{tabular}

This would show that the ratio whieh the catch of bachelors bears to the whole herd has clianged from 1 to 20 in 1897 to 1 to 9 in 1909.

The percentage of bachelors dismissed from the killing field in 1897 was 41 per cent; in 1904,44 per cent; in 1905, 40 per cent: and in 1909, 32 per cent. This shows that killing in 1909 was 9 per cent of these males; the reserve has fallen steadily to 4,000 rejcetions in 1909 , ineluding those among the marked bachelors. Its steady diminution during this period apparently indieates that to maintain the quota at a stable figure this reserve had to be drawn upon more heavily every succeeding year; or, conversely, the rejertions each year became fewer in order to secure the quota. It certainly is irue that a steady but gradual reduction occurred in the number of bachelors rejected, and had such reduction not been made the quota would have suffered.

The reduction of this reserve will make it a matter of difficulty to secure a quota in 1910 approaching in size that of 1909 . With fewer of the older animals to draw upon, dependence will be had mainly upon the young or 2-year-olds. With the chance that there will be fewer of these than in 1909, it would appear problematical whether enough can be found to equal or approach the catch of 1909.

The proportion which the pelagic eatch bears to the whole herd has changed also. In 1897 the pelagie catch, 24,321 , bore the same rolation to the whole herd, 402,850 , as I to 16 . In 1908 it was as 1 to 8 $(18,151: 146,636)$. From this it would seem that the pleagic scalers are killing twice as many seals in proportion as they did 11 years ago. This is another singular fact in connection with the subject, showing that conditions at the present time diferentirely from previous years.

It may be that by the methods of estimation used, the number in the whole herd in recent years nas been placed too low, or, rather, that there are more seals in the herd than are given in the estimates or censuses. It is either in this possibility or the one already mentioned - that tho mortality among pups is less than hithorto - that the cause of this change of relation of bachelor cateh to the whole herd must be sought. (Appendix A, pp. 763-764, June 24, 1911, House Conmittee on Expenditures in the Department of Commerce and Labor.) 
This Elliott figure of about $1,000,000$ seals for 1897 , as against 376,000 which Jordan declared to be the "first accurate census," was really the correct total for that year; there must have been at least as many seals alive then, or it would have been utterly impossible to find 190,950 of them alive in 1913, as were found by Elliott and Gallagher during their survey made July 10-20, 1913.

Those Jordan commission census figures, which hare been annually published officially since $1896^{\circ} \mathrm{by}$ the Departments of the Treasury and of Commerce and Labor, have all been precicated on these erroneous figures of 1897 , which Dr. Jordan and his associates have steadily insisted were accurate and not misleading.

There is another salient fact brought out by this 1913 census of Elliott and Gallagher. There is an entire absence of idle or surplus breeding bulls; they hare been completely eliminated by this close killing and illegal taking of them on the islands.

Even that callous officialism of the Bureau of Fisheries was frank to make the following statement to the committee February 29, 1912, when questioned closely about the killing of young male seals under its direction:

[Hearing No. 9, Feb. 29, \{1913, pp. \{368, 369, House Committee on Expenditures in the Department of Commerce and Iabor.]

Mr. Lembrey. It might be claimed that the size of the herd of idle bulls is very small, and that therefore not enough male seals escape the killing grounds to maintain an ideally healthy relation between breeding males and females. It is true that the number of idle bulls is small.

In a highly polygamous species, such as the committee understands the fur seal to be, no injury can be wrought to the species from the killing of the young nonbreeders, unless that killing became so drastic as to prevent the survival of enough males to properly reproduce the race. Such surplus males as are not required for breeding purposes are as useless zoologically as if they did not exist. Unless, therefore, it can be proven that the killing on the Pribilofs has resulted in the culling of males so closely that not enough bulls were at all times present to properly fertilize the females, it assuredly can not be claimed that killing of these surplus young males does injure or ever has injured the species.

The absence of a sufficient number of males would become apparent through any one or both of the two following means, namely:

1. The absence of idle bulls on the breeding rookeries.

2 . The presence on the rookeries of adult females without young.

The presence or absence of idle bulls on the rookeries I regard as the most conclusive test to be applied in determining whether or not a sufficiency of adult males is present. Given a surplus of bulls, or more than enough to provide all the cows with consorts, we can be fully assured that there are enough bulls present for breeding purposes, or, as David Harum says, "A little too much is just right." On the other hand, if there are no idle bulls present, it is impossible to ascertain whether enough males are on hand to insure the impregnation of all the females. But we can be well assured of that fact in the face of a number of idle and active bulls. It is a significant fact that, in the whole mass of evidence presented to this committee to prove injury to the herd through land killing, nothing has been laid before it to show any scarcity of bulls, nor, so far as I know, has the subject been mentioned. No allegation of that character has been made, for the very sufficient reason that no evidence of that nature exists. At all times in the history of the seals have idle bulls been present, sometimes more than at others, but always a surplus. Until the critics can successfully allege an absence of surplus male life, their strictures upon land killing must lack value. Under present regulations, which require the exemption from killing of many choice males each year, an elimination of the idle bull class can not occur.

That the "idle bulls" had completely disappeared from many of the breeding grounds by July 10-20, last, was freely admitted by the agents of the United States Bureau of Fisheries who accompanied 
Messrs. Elliott and Gallagher. At rare intervals on the other rookeries a bull without place or location near the overcrowded harems would be seen - a fair and fit indication that something defective in its organization caused its indifference and vagrancy.

This complete disappearance of the "idle" or surplus "breeding bulls," as above stated, which should be hovering around the outer lines of the harems, the complete disappearance also of the "polseecatchie" or 5-year old bulls, too, makes the following statement of record, timely now, for it again tells the story truly of how and why this surplus male life laas been thus wholly eliminated as a factor on these Pribilof rookeries by 1913.

In making his argument for the need of checking up the close killing of all the young male seals as done by the lessees since 1596 , to date of 1903 , Mr. Elliott made the following statement of conditions then, which holds good to-day. It clearly shows how, and why this excessive and illegal killing of "yearlings and seals having skins weighing less than 6 pounds" has brought this herd to the very verge of complete physical destruction under the Russian régime of 1817-34, and under ours, has done so again, to-day. In a letter dated January 8, 1904, addressed to the Secretary of Commerce and Labor, Mr. Elliott said:

JANUARY $8,190.1$

The Secretary of CoMnerce And Labor,

Washington, D.C.

Sin: I respectfully submit the following siatements of fact, without adding any opinions of my own, as the hasis of a proper request for prompt artion on your part in orler that the fur-seal species of Alaska shall not be completely destroyed, root and branch, on the Pribilof Islands during the coming season, under existing rules and regulations.

The commercial ruin of our fur-seal herd was effected at Paris, Angust 16, 1893. I will not advert to the errors of our own agents in charge of our case which led to this humiliating result. I should say at this point that 1 did all in my power in 1890 and 1891 to prevent the course mapped out and followed to defeat by these agents. Mv protests in November, 1890, and in Jannary, 1891, to Mr. Blaine were in vain and I had nothing to saly or do with the maganement of that case after the fith day of Jamuary, 1891; my knowledge and mderstanding of the subject were ignored, and save the tardy ancl forced adoption of the modus vivendi of 1891-1893, which I urged in November, 1890, 110 argument or wish of mine prevailed in the preparation of this case. I am in no way responsible for the wretched conduct of that case of our Goverument before the Paris tribunal and its resultant shame and misery, to say nothing of the immense lose of public property also following.

The figures and facts which I herewith present for your information and use declare that the bitter sequel of commercial ruin for our interests on the seal islands of Alaska is right at hand; that sequel is the immediate extermination of this anomalous, valuable, and wonderful marine life which must exist on the Pribilof group, but it can not and will not exist by its own law of life anywhere else.

By way of introduction to the following tabulated statements showing the rapid decline of the fur-seal herd since 1872 permit me to say that I am, fortunately, in possession of the complete and indisputable proof of my statement that 4,500,000 fur seals - cows, bulls, and pups-were in existence on the rookeries and hauling grounds of St. Paul and St. George Islands, in fine form and condition, during the seasons of 1872-1874, inclusive. I am fortunate in holding all of this indisputable and self-asserting evidence just as it was secured and recorded in 1872, 1873, and 1874; the original records, surveys in detail, and notes are mine. That point of departure in 1872-1874 enables me to authoritatively and clearly express to you the real loss of life which the Government has sustained in this ruin of its industry on the seal islands of Alaska; without it no adequate expression of the trith could be made by myself or anyone else which would be credible and accepted by the judicial mind. The first point to which I desire to draw your attention is the following official record of the loss of life on the seal islands of Alaska from 1872 down to 1903, inclusive: 
Number of fur seals-males. females, and young.

1872-1874. The surveys of Elliott and Maynard; act approved Apr. 22, 1874 . 4, 500, 000

1890. The survey of Elliott; act approved A pr. $5,1890 \ldots \ldots \ldots \ldots \ldots \ldots . . . \ldots 59,000$

1891. The Canadian-American Joint Commission survey, "about"...... 1, 000,000

1896. The Jordan-Thompson Joint Commission survey' (p. 222 of Jordan's preliminary report, Treasury Department Doc. No. 1913).........

1897. The Jordan-Thompson Joint Commission survey declares that "the rookeries on which the pups were counted show a reduction of 14.4 per cent" (i. e., 14.4 per cent fewer seals than in 1896).........

1898. Report Secretary of the Treasury, page xxxiv, Dec. 6, 1898: "The conditions of the rookeries show a most apparent decrease in the numbers of seals frequenting the islands." No estimate of percentage of loss is made, but it can not be "most apparent" unless that loss of life is at least 12 per cent of the figures agreed upon in 1897 , or......

1899. Report Secretary of the Treasury, page xxxi, Dec. 5, 1899: "The condition on the rookeries shows a continued decline in the herd." ("The agent in charge reports a decline of 20 per cent" from the figures of 1598.--Report Secretary of the Treasury, p. xxxii, Dec. 4, 1900). This gives us.

1900. Report Secretary of the Treasury, page xxxii, Dec. 4, 1900: "The agent in charge reports that the seal life on the islands in 1899 was 20 per cent less than in 1898." "The rookeries were examined during the past season by an agent of the Fish Commission." "He reports a decrease in the seal life on the rookeries as compared with former years." "Smaller seals were taken this year than ever before." Report United States Fish Commission, 1900, page 165: "The seals have been diminishing upon the breeding grounds for many years, the annual decrease during the past few years amounting to about 20 per cent." This testimony reduces the herd in 1900 to

1901. Report Secretary of the Treasury, page 38, Dec. 2, 1901: "The enumeration of live pups shows a marked falling off from the previous years." A "marked falling off" in the number of pups would not be noticed as such unless the percentage of loss was at least 12 per cent, or.

1902. Report Secretary of the Treasury, page 30 , Dec. 3 , 1902: No mention or hint of any decrease in the herd in this report; but a set of erroneous figures is given for the pelagic catch of the year; only onethird of this catch is announced. Upon this false return of that catch is based an allegation that the pelagic hunter is retiring from business, and this retirement puts the "herd in a more stable condition," and that "it is not decreasing now as rapidly as heretofore." Also no reference whatever is made of the new "Japanese" sealing fleet which joined the Canadian fleet this season and has been busy all around the islands inside of the " 60 -mile zone"; no reference is made of this new power for destruction, although the department on Sept. 25, 1902, received an official report declaring that 16 of these vessels were thus engaged. Therefore, since the same forces of destruction which have been at work on the herd since 1896 have again been all actively employed with the addition of the " 16 Japanese" vessels, it is only reasonable to declare a reduction of at least 12 per cent from the number allowed for 1901, and this gives us at the close of the season of 1902 not to exceed

Also, in this report of the Treasury Department for 1902 is omitted the statement of the special agent in charge of the islands in his report for this year, that "a careful count of harems made this year shows a falling off of 25 per cent of breeding bulls." The reason why this important fact is omitted is evident to any intelligent reader; it would ntterly deny the Secretary's assertion that "the herd is in a more stable condition"; it is therefore suppressed. 1903. The Government agent declares that at the close of the season of 1903 the number of seals alive does not exceed.................

264,962

233,962

204,887

180,000

The season he refers to closes A ug. 1, 1903. 
A reeapitulation of the foregoing official record of the rate and progress of the decline of the fur-seal herd of Alaska shows, concisely, that there were in-

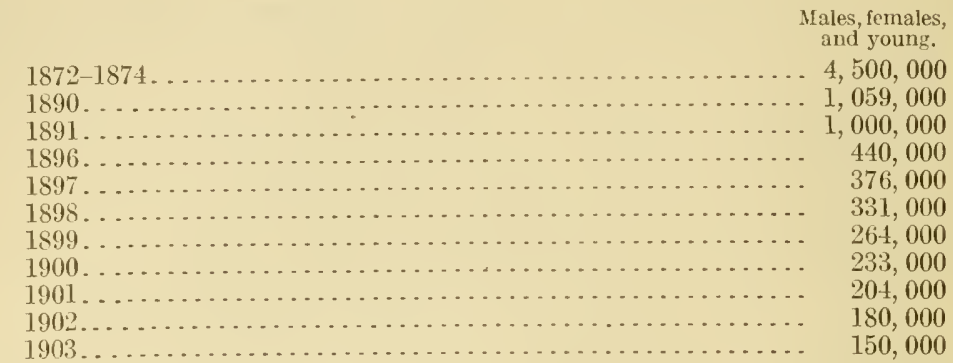

Also, a census of the fur-seal cows alone has been officially recorded since 1896, as follows:

1896 (Jordan's report) . . . . . . . . . . . . . . . . . . . . 157, 405

1897 (Jordan's report) . . . . . . . . . . . . . . . . . . . . . 134, 582

1900 (United States Fish ('ommissioner's report). . . . . . . . . 100,000

1901 (special agent, Treasury Department, report) .......... 9. 91, 236

1902 (special agent, Treasury Deprartment, report) ${ }^{1} \ldots \ldots \ldots \ldots . . .64,8 s 2$

Certainly true it is that these bulls are "falling off." They are dying of old age on these rookeries, and no new bloor has been permitted to reach these breeding grounds since 1896 so as to fill the vacancies thus created; and it is equally certain and true that the same annual loss of cows has taken place in $190: 3$ which has marked the preceding seasons, since there has been no cessation of the work of slaughter on land and in the sea in all of those vears, and there is none to-day.

The next point in order is the following analysis of the status of the male life on the rookeries or breeding grounds, which elearly sliows the total elimination of this life by 1907 under existing rules and management.

In 1872-1874 there were some 90,000 breeding bulls and 1,250,000 cows (primipares, multipares, and nubiles), showing a birth rate of $1,125,000$ pups.

In 1890 this herd was reduced to some 14,000 breeding bulls and about 420,000 cows (primipares, multipares, and nubiles), showing a birth rate of 380,000 pups.

In 1896 this herd was still further reduced to some 5,000 bulls and about 144,000 cows (primipares, multipares, and nubiles), showing a birth rate of 130,000 pups.

In 1903 this herd is reduced to some 2,200 bulls and about 75,000 cows (primipares, multipares, and nubiles), showing a birth rate of 68,000 pups.

These 2,200 breeding bulls of 1903 are the survivors of those young males which were spared in 1890 and by the modus virendi of 1891-1893, and thus allowed to grom up to the age of 6 years and then take their places in 1894, 1895, and 1896 on the rookeries as 6 and 7 year old "seeeatehie."

In 1894 and in 1895 a few limdred 4 -year-olds may have escaped the club on the killing grounds and thus eame in as 6-year-olds in 1896 and 1897.

But in 1896 no 3 -year-old seal was passed over the killing grounds which was not killed in 1897 as a 4 -year-old.

And in 1897 and 1898 no 3-year-old seal escaped the killer's club, except to die on the killing grounds as a 4-year-old in 1898 and 1899.

And in 1899 no 2-year-old seal was permitted to escape on these grounds unless to die as a 3 -rear-old in 1900 .

And in 1900 no well-grown yearling seal was spared on these slaugliter fields, except to perish as a 2-year-old in 1901.

And iu 1901 every yearling that came asliore was taken, and if a few escaped they met the club in 1902 sure, as 2 -year-olds.

And in 1902 every young male seal that landed was taken, so that out of 22,199 , 16,875 were "long" and average yearlings, or "5-pound" or "eyeplaster" skins.

In this clear light of the close killing of the young male life as given above, it will be observed that no young or fresh male blood has been permitted to mature and reach the breeding grounds since 1896 .

The average life of a breeding bull is from 15 to 18 years; he does not keep his place longer for good and obvious reasons. The youngest hulls to-day upon that breeding

1 This increase of some 5 per cent in cows over the figures of 1901 is a self-evident blunder, because its author in his report of 1902 says: "A careful count of harems maile this year shows a falling off of 25 per cent of breeding bulls." 
ground are not less than 12 years old-most of them older. They are now rapidly dying of old age-witness the following:

An official report in 1902 declares that these breeding bulls had decreased in number from 1901 to the end of 1902 at least 25 per cent.

An official report in 1903 again declares a decrease from 1902 to the end of this season (1903) of 17 per cent; 42 per cent since 1901.

The close of the season of 1904 will show at least 20 per cent reduction again; and in 1905 again 20 per cent at least, to entirely cease by 1907 unless steps are taken at once to stop the run on this life by land (and sea killing) clubbing in 1904 of the choice young male seals, yearlings and upward, to the end of the season of 1906-stop it entirely.

I now submit a tabulated statement, which is in the form of a prophecy, based upon the foregoing figures of fact, with the reasons guiding my forecast.

A table which shows the annual rate of progress in the extermination of the fur-seal herd of Alaska which will take effect under existing rules and regulations by 1907 unless checked in 1904:

Pribilof Island seals on the islands.

\begin{tabular}{|c|c|c|c|c|c|c|c|}
\hline Class. & 1903 & 1904 & 1905 & 1906 & 1907 & 1908 & 1909 \\
\hline 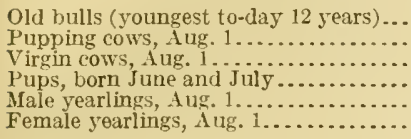 & $\begin{array}{r}2,200 \\
65,000 \\
10,000 \\
65,000 \\
1,000 \\
10,000\end{array}$ & $\begin{array}{r}1,650 \\
56,250 \\
5,000 \\
56,250 \\
500 \\
6,000\end{array}$ & $\begin{array}{r}1,165 \\
37,855 \\
3,000 \\
37,885 \\
300 \\
4,000\end{array}$ & $\begin{array}{r}400 \\
22,525 \\
2,800 \\
20,000 \\
300 \\
2,000\end{array}$ & $\begin{array}{r}150 \\
15,000 \\
500 \\
10,000 \\
(?) \\
500\end{array}$ & $\begin{array}{l}(?) \\
5,000 \\
\text { None. } \\
5,000 \\
\text { None. } \\
(?)\end{array}$ & $\begin{array}{r}\text { None. } \\
3,000 \\
\text { None. } \\
\text { None. } \\
\text { None. }\end{array}$ \\
\hline Total... & 153,200 & 125,650 & 84,235 & 48,625 & 26,250 & 10,000 & 3,000 \\
\hline $\begin{array}{l}\text { Land catch to } \mathrm{A} \text { ug. } 1 . \ldots \ldots \ldots \ldots \ldots \ldots \\
\text { Pelagic catch to Nov. } 1 \ldots \ldots \ldots \ldots \ldots \ldots\end{array}$ & $\begin{array}{l}19,252 \\
25,000\end{array}$ & $\begin{array}{l}16,000 \\
20,000\end{array}$ & $\begin{array}{r}8,000 \\
15,000\end{array}$ & $\begin{array}{c}(?) \\
12,000\end{array}$ & $\begin{array}{l}\text { None. } \\
10,000\end{array}$ & 6,000 & None. \\
\hline Total. . & 44,252 & 36,000 & 23,000 & 12,000 & 10,000 & 6,000 & (?) \\
\hline
\end{tabular}

Owing to the fact that the youngest of these old breeding bulls is at least 12 years old in 1903 and that the service imposed upon it, as a rule, ends in the sixteenth and eighteenth year of its age, this life is rapidly dying off and will entirely go by the end of the season of $1907 ; 42$ per cent of its form in 1901 disappeared by 1903 .

No young male seal above 2 years of age will appear next season (1904) on the hauling grounds, unless an order prohibiting the killing of all choice male seals above 10 months of age sliall be made for the seasons of 1904, 1905, 1906, and 1907 on the seal islands of Alaska; no fresh young male blood can mature quickly enough to come onto the breeding grounds and save the birth rate from total collapse in 1907. Even if this is done it will be a close call for that life anylow. To postpone such an order to 1905 would be too late, if the species itself is to be saved from complete extirpation. This result will ensue as sure as fate unless the killing is at once held up on the seal islands.

The full number of old bulls carried on this table from 1903 to 1907 represents all that will be seen in those years and alive on the breeding grounds; but this number is greater every season than the real number of virile or potent sires; for instance, in 1903 we count 2,200 old bulls, but a large number of them lay upon the rookery without cows. ${ }^{1}$ Why do they thus lay idle when the bulls in active service around them have more than twice as many cows in 1903 as they should have were the service normal on this field? These bulls were somnolent and idle in 1903 when the cows in the harems around them increased from a normal ratio of 22 females to 1 male sire to 44 cows to the bull.

They were thus idle because they had lost through age the vigor to attract and control a harem. I saw this state of affairs on these breeding grounds in 1890 and raised the note of alarm then for the first time; stopped the killing on July 20 , when only 19,000 of the 60,000 quota had been taken, and forced my modus vivendi througli, which took effect in 1891, 1892, and 1893.

1. The following official entry made in the journal of the United States special agent in charge of St. George Island, under date as given below, describes in detail what Mr. Elliott alludes to as "impotent bulls":

$$
\text { ST. GEORgE IsLAND, July 20, } 1906 .
$$

At a faroralble point on north rookery a cow in heat was teasing a bull, biting his neck and lifting np her hind parts, which the bull smelled. Shortly afterwards he endeavored to copulate, but soon gave up the at tempt, spread ont on the rock and went to sleep. The cow renewed her blandishments from time to time, but the bull had evidently reached his limit.

$$
118 f 54-13-2
$$


And these bulls which we see alive on the breeding grouncts now, and will continue to observe until 1907, are the survivors of the young male 2,3 , and 4 year olds which were saver in 1890, 1891, 1892, and 1893 , phlus a few 3 and 4 year olds which may have slipped through in 1894 and 1595 .

Since 1896 no fresh young male blood has been permitted to pass the club on the killing grounds of St. I'anl and St. George, and the effect of utterly shutting ofi the birth rate by 1906 and 1907 is plainly exhibited in the analysis tabluated above.

In the light of the foregoing statements of fact, am I not warranted in asking that you at once suspend all killing on the islands by the lessees for the seasons of 1904 , 1905, and 1906; and that only such young males as may be necessary for natives' food be killed thereon during those seasons, solely under the direetion of your agents, the skin. of which can be carefully preserved and sold by the Government-the proceeds thereof turned in th the Public: T'reasury?

You ean not divide the authority for killing on the islands in the present condition of affair between your agents and the agents of the lessees, withont scandal, confusion, and failure.

Fon have full and ample power to suspend all killing of seals by the lessces under the distinct terms of their lease. whenever the preservation of that life is at stake, and which you are especially charged hy Congress to preserve; the lessees have no recourse on the Government, under existing conditions, if you suspend their operations indefinitely, by the express terms of this lease, and which was drawn by Mr. Windom in March, i890. for the very purpose of meeting just such a contingency as now arises. I know it, beeause I was consulted by him when he was drafting it.

Igain, the lessees have no ground of complaint, legally or morally, if you entirely suspend their work: they have made an enormous profit annually since 1890 . even through the short-killing of the modus vivendi in 1891-1893. The entire amount of their capital invested in the plant on these islands is only $50,7,000$.

I have detailed figures which rleclare their antual profits since 1900 to lave been simply enormous from a commercial standpoint; the fur trade has recognized the fact that the end of supply from the seal islands is near at hand; and since 1897 a steady immense rise in price per skin, no matter how small, has taken place 1 p to rate, making the protits on the isfand catches and the pelagic eatches way beyond the figures of greatest values ever known to the business since 1900.

This step which I ask you to take is provided for by existing law; there are other steps which I think you onght to take, but which you can not take until Congress acts; of them and about them I desire very much to confer personally with you.

I am, very respectiully,

Your friend and servant,

HenRY W. ElLioter,
12,8 Fourteenth Strect NW. Washington, D. C.

This statement, as above, stirred Mr. F. H. Hitcheock, who, as chief clerk of the department, had the entire administrative details of this business in his hands. He issued those elnecks upon that work of the lessees which Mr. Elliott called for on May 1, 1904, and which are now so well and favorably known to the committec as the Hitcheock rules.

These were enforeed fairly well in 1904 and in 190.5, but after that the greedy lessees prevailed upon the acents so that the "sared" seals in June and July were all secured as "food seals" during the same season in October and November following. So thorough was this nullification of the IItcheock rules brousht about since 1906 that to-day the most careful survey between July 10 20 last failed to disclose the presence of a single "idle" able-borlind fur-seal bull on many of the 17 desolated breeding crrounds of the fur-seal herd on the Pribilof Islands.

The absolute necessity of letting this young male life rest from "scientific" disturbance, such as the driving of the pups to "count" them, and from the senseless slaughter of all the "yearlings" with the 2,3 , and 4 year old males during the next five years is way beyond any sensible objection or even argument to the contrary.

'The proof conclusive of that erroneous census of Dr. Jordan's commission in 1896 , when he declared that a "true count" such as he had made then showed the presence of only 440,000 seals on the 
Pribilof breeding and hauling grounds, is well brought out by the following testimony, giren to the House committee April 20, 1912. in hearing No. 10, pages 605, 606, House Committee on Expenditures in the Department of Commerce and Labor, to wit:

AS TO KILLING ON LAND AT THE HISCRETION OF DEPARTMENTAL AGENTS, IN RE FURSEAL HERD.

Mr. EllnotT. How can any "percentage of reservation" of "10 per cent" or "25 per cent," or "50 per cent," or "9.5 per cent" of young male life be "safely fixed" by man upon the basis of the following self-evident, worthless, and padded census of the fur-seal herd of Alaska?

Ever since 1900 the departmental reports to (ongress have annually declared an immense loss suffered by the lur-seal herd of Alaska imm the work of the pelagic hunters, yet never has this annual loss been subtracted from the sum totals of their ammal census tables officially sent to congress. Why?

Witness the following proof of it officially given:

The official census of the fur seal herd of Alaska as annually made and published since 1904 declares that there is not a fur seal in existence on the Pribilof Islands at the close of the season of 1910 , if the official statements of annual loss made from pelagic sealing are computed.

Official reports of Department of Commerce and Labor to Congress from 1904, annually, made to close of season of 1909 , declare that in-

$1904,243,103$ seals of all classes alive August 1,$1904 ; 1905.223,000$ seals of all classes alive August 1, 1905; 1906, 185,000 seals of all classes alive August 1, 1906; $1907,172.502$ seals oi all classes alive August 1,$1907 ; 1908$ (no figures), August 1, 190s; 1909, about 140.000 seals of all classes. August 1,$1909 ; 1910.137,000$ seals of all classes alive August 1, 1910; 1911, about 133.000 seals of all classes alive August 1, 1911.

These official figures of the Secretary of Commerce and Labor are quoted verbatim from those amnual reports as appended. They declare the fact that if the figures of 1904 are correct, then. by the figures of annual loss alone since that season, there is not a fur seal in existence on the seal islands of Alaska since 1908.

In these departmental tables the strange and inexcusable error is made of not subtracting the Ioss entailed anmually, aiter August 1 to Norember 30 , by the pelagic sealers' catch. If that loss is taken from this count, as it must be taken, then those departmental tables will show a finish in 1907 as follows:

At the close of the season of $190 t$ the pelagic catch irom this Alaskan herd was 22.670 seals. Taking the department's own estimate of this loss as about "three seals killed for each one taken," then there is a total of some 67.000 seals to subtract from 243,103 seals alive August 1. That would leave alive at the opening of season of 1905 only 177,000 seals in round numbers instead of 243,103 .

Seals, male and female.

when the season of 1905 opened there were $\ldots \ldots \ldots . . .177,103$

Then the lessees took therefrom up to Aug. 1..................... 14,000

Leaving thell. . . . . . . . . . . . . . . . . . . . .

Then the pelagic catch from August to November was 20,000 , or a loss of... 60,000

Thus leaving alive at the opening of 1906 only............. 103,103 Then the lessees took up to Aug. $1,1906 \ldots \ldots \ldots \ldots \ldots \ldots \ldots \ldots \ldots \ldots \ldots \ldots . . . . \quad 14,000$

Leaving then only. ............................ $\$ 99,103$ Then the pelagic catch, August to November, follows, of 20,000 , or loss of.. 60,000

Thus leaving alive at the opening of 1907 only: ............ 29,103

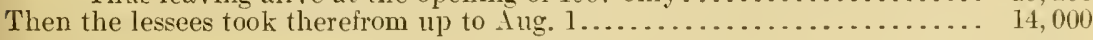

Leaving then only ........................... 15, 103

Then the pelagic catch, August to Norember, 22,000, or loss of . . . . . . . 66,000

Thus leaving not a single seal alive at the opening of the season of $190 \mathrm{~S}$.

In the light of the above reduction of those figures of seal life and its status from year to year, is it at all strange that those authors of these grotesque census tables should juggle my figures in vain, as given on page 99 . Hearing. House Committee on Foreign Iffairs, January 4, 1912? 
The estimates of loss ${ }^{1}$ which the Bureau of Fisheries put upon the killing of females by the pelagic hunters are excessire; true when the adult primipari (female) is killed heary with roung, but not when the nubile is slaughtered. That makes their charge of "three seals is lost to the herd for erery female taken," excessive. But, nerertheless, since ther have ammully repeated this charge against the killing of the pelagic sealer since 1890 to date of the sealing treaty now in effect, December 15, 1911, the effect of their making this heary loss so specific should have been enough to warrant a large deduction from their ammal "paper census" that "accurate and careful counting" of the herd which is set forth to the committee in the following dogmatic words:

[Hearing No. 9, p. 367, House Committee on Expenditures in the Department of Commerce and Labor.]

Mr. LembKey. Many erroneous statements have been made to this committee and to the Committee on Conservation of National Resources in the Senate as to the number of seals which now compose the herd.

In view of this confusion of data with which the committee has had to contend, it may be well to give to it at once a detailed statement of the census of seal life on the Pribilof Islands as taken at the close of the last season, 1911:

Bulls, active (with cows)........................ 1, 356

Bulls, adult, but idle (without cows).......................

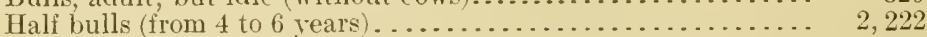

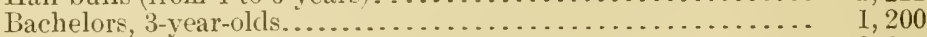

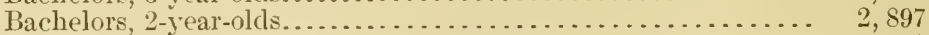

Bachelors, 1-year-olds............................. 15, 322

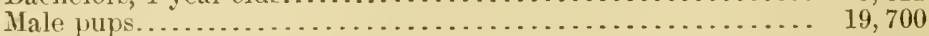

Breeding females. ................................. 39,400

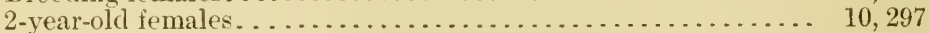

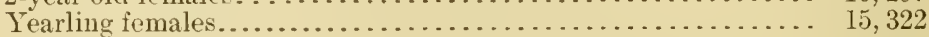

Female pups............................. 19,700

Total.................................... 127,745

1 This great loss annually, never noted or countcd by the scientific census takers of the Pribilof herd, from 1904 to 1912 .

Aside from the great loss in seals which are shot and not recoverable it must be remembered that nearly 80 per cent of all seals taken in Hering Sea are pregnant femafes having nursing pups ashore, which die of starvation after the foss of the mother. The death of each pregnant female, therefore, means the loss of three lives tn the herd, in addition to the great waste incident to the nonrecovery of seals shot in the water, which has just been referred to.

In view of the facts just mentioned, it may fairly be believed that the catch of 27,216 skins by the pelagic fleets in 1907 renresents a loss to the herd of upwara of 75,000 animals. They show that to secure 27,000 skins on land only that number of animals need be killed, and the surplus males which can be spared without injury, while to secure 27,000 skins in the water practically 75,000 animals must be slaughtered. Stronger proof of the destructireness of this practice and of the certainty and rapidity with which it reduces the herd can not be given. (Annual Report Seal Fisheries of Alaska, 1906. By W. I. Iemhkey, agent in charge of Alaskan seal fisheries. Department of Commerce and Labor, Division of Alaskan Fisheries, Washington, Dec. 14, 1906. P. 279, Appendix A, June 24, 1911, House Committee on Expenditures in the Department of Commerce and Labor.)

With regard to this matter of the number of fur seals in existence during 1872-1874, which Dr. Jordan has asserted never exceeded two and a hall milfions $(2,500,000)$, and about which he knew absolutely nothing (and after a few weeks of experience spent on the islands), it is interesting to note the opinion of WV. I Lembkey. who has passed every season on the rookeries of St. Paul Island since 1899 to the end of the season of 1913 , or 14 breeding summers (and three winters also of this period), to wit:

He testified before the Ways and Means Committee of the House of Representatives, Jan. 25, 1907, as follows (p. 66, MS. Notes of Ḧearing):

"Mr. LEMBKEY. In 1870 conservative estimates placed the number on the Pribilof Islands between four and five millions; to-day there are probably not over 180,000 seals in the entire herd.

"Mr. Williams. At the end of 18 or 19 years, if no killing at all, you think they would go back to between four and five millions?

"Mr. LEMBKEY. I have no doubt they would"

Contrast the above opinion of Lembkey (who indorses the Elliott figures) with that of Jordan below, who, in 189\%, after insisting that there were only 376,000 seals of all classes alive then in the Pribifof herd, had the following to say of the F.lliott figures of 4,700,000 seats in 1872-1874 and 1,020,000 in 1890:

12. "T'o sum up the whole matter, we are unable to aecept Mr. EHtiott's estimate as representing anything more than an individual opinion greatfy overdrawn by a too vivid imagination.

"In making the above eriticisus of Ir. Elliott's census, it has not been our purpose to tear down and condemn work which in many respects under the circumstances deserves commendation; but a disposition has of late been manifested to insist upon the absolute correctness of these figures, and in setting them aside it becomes necessary for us to give reasons for such action."

13. Elifiott's estimate of 1890 "is as bad, if not worse, than the first." "It is not possible to suggest any any explanation or justification for the vagaries which these estimates of Mr. Elliott show. 
Mr. MADDEx. Is that all on Pribilof Islands?

Mr. LEMBKEY. On both islands, that is the number constituting the present herd at the close of the season of 1911.

The above statement ${ }^{1}$ was made February 29, 1912, with the approval of the entire "scientific" advisory board on fur-seal service of the Bureau of Fisheries: and ret, a few months later, a census was made by these same officials who have been busy with it ever since Jume, 1S96, declaring that instead of there being only " $127,000 "$ seals of all classes alive on August 1, 1912, there were "215,000."

The authors of this last census were Messr's. Lembkey and George A. Clark, the latter being the same man who aided Dr. Jordan to make his "accurate census" of 1897 , when he ridiculed the idea that the figures given by Elliott in 1890 were sensible or fair.

But the common-sense surver male this season of 1913 by us declares the fact that at least $1,000.000$ seals must have been in existence on the Pribilof rookeries during the season of 1896 , and that Jordan's total of " 376,000 " for the season of 1897 is one that is evidently and self-confessedly wrong, by the rery logic of events.

The exposure of the 1911 census of the Bureau of Fisheries as a sham and without any foundation of fact, April 20, 1912, to the House Committee on Expenditures in the Department of Commerce and Labor (pp. 605-606, Hearing No. 10), stirred those scientists to try again and land in 1912, with some finding of sense.

AN ANALYSIS OF THE FIGURES OF THE CENSUS OF THE JORDAN COMMISSION, $1896-97$.

In 1597 Jordan declares "an accurate surver," based on "actual counts," shows that there are only 129,216 seal cows in existence on the Pribilof rookeries. (Treasury Doc. 1994, 1s9s, p. 15, Nov. 1, 1897.)

In 1912 Jordan's man of 1S97. G. A. Clark, declares an "actual count" shows that full $\$ 1,000$ seal cows are now in existence on the Pribilof rookeries. (Economic Circular No. 10, Dept. Com. and Labor, Dec., 1912.)

1 In spite of this sworn statement made by Lembker, Feb. 29,1912 , yet the fact that he knew that he did not give that committee a true figure is furnished by himself, as follows, in his report to the department for 1908, to wit:

"The difference between the counts of pups made in the two years is so slight as to indicate on their face that practically no change in the number of breeding cows has occurred. If these counts were taken as a criterion of the condition of all the rookeries on the two islands, we would have to believe that ther has been no decrease in breeding female seals during the past year. This conclusion, however, would be hard to accept.

"If the number of breeding seals has not decreased, as these figures would lead one to believe, where, then, could the catches of the pelagic fleets have been obtained? It is known that in 1907 some 17,000 sealskins were marketed by the two fleets-Canadians and Japanese-most of which were those of female seals. This, of course is in addition to the 15,000 young male skins taken in 1907 on the islands by the lessee. A total of 32,000 skins, therefore, was taken from the herd in 1907 , which, in that year, was composed approximately of 175,000 animals, of which only 65,000 were adult and virgin cows.

"In addition to this slaughter in 1907 , the catch of the pelagic fleets in $190 \mathrm{~s}$ has been as heavy as in the preceding year. The Canadian fleet, it is true, contains fewer vessels this rear than ever before, 8 in all. As against this, however, we have an increased Japanese fleet, composed approximately of 38 vessels. Those pelagic schooners that have been spoken this year by the patrolling vessels were found to have been quite successful. The 2 schooners captured last July by the U. S. S. Bear had over 700 skins between them.

"With all this activity, it is impossible to beliere that so many seals could have been taken ont of the Pribilof herd-now only a skeleton-without decreasing the size of the herd. With so many agencies consuming the life of the herd, there is only one factor to offset this decrease, namely, the anmual increment of virgin cows. If we are to accept the conclusion that no decrease occurred between 1907 and 1908 , We must believe that the increment of virgin cows during the period mentioned was as large as the catch of the schooners, added to the land killing, the loss from natural causes, and the waste from seals killed in the water and not recorered. Such a conclusion can not be justified by conditions." (Appendix A, pp. 602-603, June 24, 1911, House Committee on Expenditures in the Department of Commerce and Labor.)

With that distinct understanding, as above stated $\mathrm{by}$ himself, that this base of his census calculation (the Jordan figures of 1897) was wholly in error, yet he returns to it, and continues the sham census, by summing it up for 1908 , as follows:

"In 1907 the whole herd was estimated at 172,512. A deduction of 15 per cent from this number would leare 146,636 as the estimated number of animals in the Pribilof herd at the close of the season of 1893.", 
In 1913 Elliott and Gallaghel declare that an "accurate surrey" and close estimate show that $\$(0,000$ seal cows are now in existence on the Pribilofs.

The above records of $1912-13$, declare the fact that Dr. Jordan's census of 1897 (p. 15, Treasury Doc., 1994: Treasury Dept., 1S9S), as above cited, was wholly misleading and far short of the truth, for the loss to that herd of sial cows at the hands of the pelagic hunters since 1897 , ammully, has arcraged not less than 25,000 , or a sum total of 350,000 cows in 11 rear's up to 1913 .

That loss of 350,000 cows has caused a still greater loss to that herd; it has caused the loss of 350,000 newly bor'm pups on the islands, and at the same time the loss of that $3.50,000$ pups which would have been born had the mothers not been killed, in the rears following that slaughter. 'That loss of thee seals to the herds" sum total, when the cow seal is killed, declares that this held of 1597 has lost anmually since then at least 60,000 seals, or 840,000 , from pelagic sealing alome; therefore at least 1,000,000 scals, or at loast ,00,000 cows, must have been in existence when Dr. Jordan declared there were only 12, 216 of them on the Pribilof rookeries in 1897.

And, further, the census of 1913 , showing 80,000 cows, or $] 90,155$ seals of all classes, alive on the pookeries then, declares the fact that the census of 1590 , made by Elliott, in which he located 400,000 cows (a total of 959,000 seals of all classes), was fainly accurate and well founded.

THE FER-SEAL CENSES-CONCLLDIXG STMMARY, AND RECAPITLIATION OF TIE HOUSE CENSLS SURVEY OF TIE PRIBILOF FUR-SEAL HERD OF 191:3.

The sea rookery marein seals are all lying down into the surf wash to-day. All of these harems are fairly awash at this date (July 10-20, 1913), on the sea mareins of the rookeries of both islands. In $185+1$, and again in 1890 , these seals laid up above those smif-washed margins at least 7 to 10 fect higher than they do to-day. Why are they desconding into the danger of "surf nipping." which will destroy those newly bon pups during violent stoms? Why, when there is the wide open area now racant, (on which they rested in 15.4 , and 1890 , right behind them ? ${ }^{1}$ What has disturbed them! What has caused them

1 The following note officially entered in the journal of the Lnited states Treasury agent, st. Paul Island, under date of Oct. 11, 1594, gives a fair idea of what a "surf nip" is and what it meaus as a danger to thé newly-born pups:

"Thursday, Oct. 11, 1894.-In company with H. D. Chichester and Vicoli Krukoff, visited North East Point and counted the dead pups, resulting in the finding of 2,547 . Civing to the tremendous surf of the past few weeks the rookeries were well washel and thousands of dead pups carried out to sea. Neon Mandrigan, who is in charge of the watchmen. reported that at times the entire rookeries were submerged, and this statement is horne out by the fact that the point is almost separated from the mainland, the only passage being the sand beaches on either side, the intervening ground heing covered with water, and forming a huge lake.

"Thursday, Aug. 29, 1895.-1 howling southeaster 1,lowing all day. A large surf on all sides of the island.

Under dale of Sunday, "Sept. 29,1495 " (p. 4n3), as to the effect of surf nip on pups, oc "urs the following:

"Special Agent Adams, in company with Dr. Yoss and 1ppulon Bordofsisy, inade a count of dead pups on Lagoon Reef rookery. Only one dead pup was found adjapnt to the water's edge, owing to the recent southwest gales, during which the surf washed over the lower breesing grounds. The count was as follows: Dead pups, 300: pups in dying condition, 40.

On page 410 , under date of "IIonday, Nor. 11, 1s.5," sperial Igent Idams de lares that this rustling among the pups, cows, and bulls to count the dead pups is detrimental, in the following language:

"Examinations of the Reef, Lukamon, Polovina, Ketavie, and Tolstoi, demonstrate the far.t that the seals are mixed $u p$, pups and cows leing together and hauled well hack from the water, a condition which I am informed has never existed hefore to such an extent. It has, therefore, been imposible to make drives from the alore-named rookeries. I certain drive was ordered from 11 iddle II ill. The seals seemed restless, a condition noticealle ever since my return to the island, sept. 13 . Whether this is due to constant disturliance luring the summer and hreeding season, they lieing constantly subje ted to scientific investigation, can not say positively, hut am of that opinion. The (*unting of pups on the rookerias necessitates the driving off of all seals, and is detrimental. It shumld he stopped. 
to lie so much lower and closer to the danger of "surf nips," which they naturally and instinctively avoided heretofore, in 1574, and again in 1890 ?

There is an answer, and it is this: From 1896 to date they have been hunted from above at the margius, as the holluschickie began to haul in between the harems for shelter and relicf from the native driver's of the lessees.

The first work of this kind in 1890 was stopped on July 20 of that season, and was not resumed until 1s:94. When the modus vivendi of 1890-1893 ended, as it began in 1591, then this improper search for the holluschickie was renewed by the lessees ammually, up to the date of their last killing in 1969. Then in 1912 began the last and most imperper driving of these harems, as done by George $A$. Clark, for Dr. Jordan; he says that he drove atl the harems up between August 1-10, 1912, from their locations, to the high bands in the rear, so as to "count" the "bunched" small black and newly born pups left behind their parents in this mad seramble and smothering rush. That disturbance prior, and since, by this clriving has caused those "pocket harems" to get closer and closer to the water, so that now, to-day, no one can get in between them and the surf at any time, and so surprise and drive them.

This survey which we have just finished here on St. George Island of all of these Pribilof rookeries secms to confirm the opinion that this constant disturl,ance of the brecling seals, at the rery time that they should be left alone of all times, is wong; for it is done when they are still busy and nerrous with their reproductive burdens and instinets, as they lie seattered on the rookeries here between August 1 and 15 following. Not only do the proofs appear that this "scientific" disturbance drives the seals rown to the water's edge near the surf when they locate anew in the following rear, instearl of going higher above it, as they used to do, but the St. George's log shows clearly that it is impossible to "count" all of these pups," and that it is only an estimate after" all ; no better than the cow "count" or estimate, as we lave made it to-day. "Taking a cow "count" at the height of the scason this ycar with duc allowane for cows which, with pups, are absent, and locating the harems as we have on these charts accompanying this rescription, enables one next year to do as we have done, and to follow and relocate all harems as they may appear again on the same ground; and, as they shall increase, so that grouml will expand. If they derereas', that ground will be diminished in area. This shows at a glanes as well if not better than any attempt to get at exact numbers, which, in fact, never can be ascertained by any man. When they shall have increased so as to overflow these boundaries of 1890 , on the annexed charts, then it will be time to talk about killing "surplus" male life; ancl also when it does reach those boundaries of 1890 ), eventually to attain those of 1874 , then no living man can "count" the pups, or "count" these scals. If ho wants to know from that hour whether this helel is increasing or diminishing as they kill the seals annually, he will only know it as this ground orevipied by them expands or retracts from the lines it oceupies this year, as compared with those of last Tear.

1 See official entries in Exhibit $\mathrm{C}$, postea, showing the impossibility and the futility of at tempt to count all the live pups on any rookery. 
In 1874 Ifenry W. Elliott made the following analysis of a detailed description of the natural habit of fur seals on the brecding grounds in which he, after three suecessive summers spent in the study of this life, recognized the wonderful system and regular order of the wild life which these seals follow. It is found on page 67 of House Document Xo. 175, Fifty-fourth Congress, first session, to wit:

\section{REVIEW OF STATEMENTS CONCERNING LIFE IN ROOKERIES.}

To recapitulate and sum up the system and regular method of life and reproduction on these rookeries of St. Paul and St. George, as the seals seem to have arranged it, I shall say that-

First. The earliest bulls land in a negligent, indolent way, at the opening of the season, soon after the rocks at the water's edge are free from ice, frozen snow, etc. This is, as a rule, about the 1st to the 5th of every May. They land from the beginning to the end of the season in perfect confidence and withont fear; they are very fat, and will weigh on an average 500 pounds each. Some stay at the water's edge; some go to the tier back of them again, and so on until the whole rookery is mapped out by them weeks in advance of the arrival of the first female.

second. That by the 10 h or 12 th of Jume all the male stations on the rorkeries have been mapped out and fought for, and held in waiting by the "seecatrlie." These males are, as a rule. hulls larely ever nnder 6 years of age: most of them over that age, being sometimes three and ocrasionally rloubtless four times as old.

Third. That the corrs make their first appearance as a class on or after the $12 \mathrm{th}$ or 15 th of Jume, in very small numbers, hut rapidly after the 23 d and 25 th of this month every year they begin to flock up in such numbers as to fill the harems very per(eptably, and by the sth or 70 th of July they have all come, as a rule-a few stragglers excepted. The average weight of the lemalo now will not he murh more than 80 to 90 pounds each.

Fourth That the breeding season is at its leight from the 10 th to the 15 th of July every year. and that it subsides entirely at the end of this month and early in 1 ugust; also, that its methorl and system are confined entirely to the land-never efierted in the sea:-

Fith. That the females lear their first yomng when they are 3 years old, and that the period of gestation is nearly 12 montlis, lacking a few lays only of that lapse of time.

Sixilh. That the females bear a single pup earlh, and that this is born surn after landing. No exception to this rule has ever been witnossed or reeorled. 1

Seventh. That the "seeratchie," which have held the harems from the leginning to the end of the season, leave for the water in a desultory and straggling manner at its close, greatly emaciated, and do not return, if they do at all, until 6 or 7 weeks have elapsed. when the regular systematic distribution of the families over the rookeries is at an end for this seasron. I general medley of young males are now free, which come out of the water and wandorall over these rookerics, together with manyoli males which have not leen on seraglio duty, and great numbers of females. In immense majority over all others present are pups, since only about 25 per cent of the mother seals are ont of the water now at any one time.

Eighth. That the ronkeries lose their compactness and definite bounclaries of true breeding limit and expansion by the 25 th to the $28 t h$ of July every year. Then, after this date, the pups begin to haul back to the right and leit in small squarls at first, but as the season goes on, by the 18th of August, they depart without reference to their mothers, and when thus srattered the males, females, and young swarn over more than three and four times the area or' ${ }^{\prime} u$ pied by them when breeding and born on the rokeries. The system of iamily arangement and imiform rompactness of the breeding classes breaks up at this date.

Ninth. That by the 8th or 10th of August the pups born nearest the water first begin to learn to swim, and that by the 15 th or 20 th of September they are all familiar, more or less, with the exercise.

1 This question of whether or no the sex rate of pups born on the rookeries is equal was settled by EIliott in 1872 , who personally handled 1,670 pups just as they were driven up in Noveniber from the St. Paul rookeries, and saw the tally of the 7,333 others summed up in the total drive of 9,002 pups made during that month for natives' food.

Each pup was examined before killing. The males were taken and the females released. Out of this total of 9,002 pups thus driven 4,525 were males.

This experiment clearly declares the erjuality in sex as to numbers at birth on the rookeries.

The average weight of those 4,625 pups was 39 pounds 8 ounces, and their average age when killed (Nov. $10-24,1 \times 72$ ) was 4 months. Some of these pups were born early in July or late in June, but nine-tenths of then between July 10 and 20; average length from tip of nose to root of tail was 23 inehes. 
Tenth. That by the middle of September the rookeries are entirely broken up. Confused, straggling bands of females are seen among the bachelors, pups, and small squads of old males, crossing and recrossing the ground in an aimless, listless manner. The season now is over.

Eleventh. That many of the seals do not leave these grounds of St. Paul and St. George before the end of December, and some remain even as late as the 12th of January; but that by the end of October and the beginning of November every year all the male seals of mature age -5 and 6 years and upward-have left the island. The younger males go with the others. Many of the pups still range about the islands, but are not hauled to any great extent on the beaches or the flats. They seem to prefer the rocky shore margin and to lie as high up as they can get on such blufiy rookeries as Tolstoi and the Reet. By the end of this month (November) they are as a rule all gone.

With this analysis before us to-day, after looking into erery harem of the entire circuit of these rookeries, we are able to say that this is the order of their life, and that in living to-day they are following this same system as insistently as if it were never disturbed by that human agency which has brought the rast herd of 1874 to this pitiful remnant now surviving.

In 1874 every 100 feet of sea rookery margin carried on its line at least 10 bulls, and every 100 feet of depth from that margin would show a bull for every 7 feet of that. Before the cows eame, before a pup was born, these bulls fought desperately on that margin, and as they progressed backward, for those stations. Then with the first arrival of the breeding females along toward the end of June and the 4 th of July all this fighting ceased. Every bull seemed then to recognize the fact that from thence on until the end of the season he was the undisputed and unchallenged possessor of his station. The cows came out from the water as they do to-day, not in heat, not noticed or fought for, and they either lay as they landed or passerl on over those which had preceded them. filling up the stations between bull and bull to the outer limits of those breeding bulls that we have just mentioned. During all this progress of arrival, passing into "heat," after the birth of pups, and subsequent impregnation, no fighting whaterer took place between these males.

Each bull secmed to do exactly then as he does to-dar; that is, rest upon the point of vantage which he gained before the arrival of the females, unchallenged by his neighbor, though he be 100 feet array or only 6 or 7 feet. Ile may have 100 cows to-day aud be fairly lost in the medley surrounding him, as they often are under our eyes, yet the bull outside of that station perhaps $10,20,30$, or 40 feet away may not have more than 1 cow, or may have 2 or 3 . That bull nevel challenges the right of his more fortunate neighbor. He nerer steals cows. He never crosses from his station to torment or fight with the possessor of many cows, even though he has but 1, or none. We have been over this entire circuit; we have never seen a pair of bulls fighting over the possession of a cow, or in any way strugghing to tear one from the other or "trample their pups to ileath." Not an instance of that kind has occurred in this 10 days' study of that life, during the very height of the season, directly under our eyes. It never occurred in $15 \div 2$ when, on St. Paul Island, there were $\$ 5,000$ of these harems and when, on St. George Island, there were 4,000; or, in all, about 90,000 rousing, fighting bulls which, as compared with the small number found to-rlay, do not differ in the slightest in their behavior, from their coming to their going. 
The wide and scanty hauling of these bulls to-day on those breceling grounds for this season of 1913 , together with the strange massing of immens: harems around single bulls, while others inmediately around have no part in the sarviec, renders a tabulation on the basis of $1 S 72-1 S 74$, or even 1590 , entirely out of the question as a measure of just contrast. We will not attempt to do it. The figures for 1890 gave 11,70s bulls for St. Paul and Soo for St. George. We have against those figures 1,413 for St. Paul and 31 for St. George.

This declease of virile male life on the breeding grounds causes the normal ratio of 15 or 20 females to a male, narle in $1872-1874$, now to reach way beyond that ratio, to 50 or even 100 females. Many of the bulls are very old to-day. There is no appreciable number of young males left alive to take their places on these breecling grounds, nor are they in evidence, except as a shatow of what they ought to be, as we have indicated in our figures and life study description above. They eloquently testify by their absence to the disturbance of that normal ratio, which is imperative if this herel is to regain its fine form and number as recorted in 187: and 1874. We have lestrored by land and in the sea that equilibrium which nature had reestablished awa back in 18.57, after the Russians had destroyed it in 1834 , just as we have done since $18 s 9-90$ on these rookeries, and we must now restore it. It can only be restored by permitting those natural laws which gorern its best form and number to reassert themselves mchecked by us. We must let them alone until that year opens when they shall give us evidence that at least two or three millions of them are in existence of all classes as against the scant 200,000 living to-rlay.

The pelagie sealer kills all the males and all the fomales that come within his reach, from $1 s 90$ to 1912 , getting 10 per cent males and 90 per cent females.

The lessees kill all of the roung male seals, and none of the females save the yearlings which haul out on the islands from 1896 to 1910 , and that killing is continued by the department to 1912 .

Result: That (the males and females, being born equal in number) the males are all killed long before all of tho females are.

Proof: That only 1,500 breceling males are on the Pribilof rookeries to-day, while $\$ 0,000$ brecling females are there with then, and no young breeding bulls alive, to note, more than 3 years old, which do not breed until 6 rears old.

A SWORN STATEMENT OF TIE MANNER AND METHODS ADOPTED BY H. W. ELLIOTT IX MAKING A CENSTS OF THE PRIBILOF ROOKERIES, SE.ISONS OF 18:2-1874, AND 1890.

[11earing No. 4, pp. 1s4-193, Ju]y 11, 1911, House Committee on Expenditures in the Department of Commerce and Labor.]

[Cleveland Plain Dealer, Sept. 25, 1599.]

The ILASKa SEAL Question.

PROF. ELLIOTT DECLARES THAT THE CASE OF THE UNITED STATES HAS BEEN GIVEN AWAY BY THE JORWAN COMHSSION.

The final report of Dr. Jurdan wn the fur seals of the Pribilof Islands has been recently issued. The preliminary reports of this gentleman in 1896 and 1897 have been variously commented on in the press as they appeared during the last two years, and the public generally were led to believe that some practical good was to accrue from the investigation which he was conducting; but our people now know that 
Dr. Jorlan's "perfect agreement" with the British agents was a simple dlelusion which he so joyfully ammounced to the Lnited States Senite, through Senator Perkins, in these words: "England shows every indication of a desire to do the fair thing. This intention is especially clear in the fact that she has sent an honorable commission which is familiar with all the facts ascertained by us, the head of the commission having been with me every day throughout the smmmer, and he and I being in agreement on all questions of policy, as well as on all matters of fact. so far as was developed by our conversation during the expedition." (Congressinnal Record, Feb. 28, 1597, p. 2619.$)$

How badly Dr. Jordan failed to muderstand his British colleague was made plain by that gentleman's report to his Government, issued May 10, 1897, in which Dr. Jordan was taught the suber lesson that Prof. Thompson did not subscribe to him in any question of poliey respecting the management of the fur-seal herd and to no essential details of faet. (Report of Proi. D'Arey Thompson on his mission to Bering Sea in 1896, dated Mar. 4, 1S97; U. S., Nov. 3, 1897.

Now that Dr. Jordan has given public evidence of his utter inability to understand what his own field associate on the seal grounds in 1896 intended to say or do, I believe I have a good right to show that Dr. Jurdan has made an equally grave blunder in regard to what I dicl on the seal islands in $1872-1874$. and is equally incompetent to understand what I have said. In the final report of his investigation above mentioned he derotes a large space to the subject of my work on the census of the furseal herds in $1872-1874$, and in this space endeavors to show that I was "merely guessing," and making "Nr. Elliutt wholly devoid of mathematical sense, or else mist have failed to appreciate what his figures really meant."

In Dr. Jordan's preliminary report of 1896 (Treasury Department Doc. No. 1913) he alludes to this census work of mine in no such language, and mildly doubts the probability of my figures being right. He does not in this report give me the warrant to handle him without gloves which appears in this, his final report, and to handle him at once on this question is buth my pleasure and a public duty.

Let me describe my early mission and its auspices. I first set out in A pril. 1872, for the seal islands to gather information and collect for the smithsunian Institution. When I arrived on the islands April 2:2. I5:2, I landed there without the slightest pressure from anyone or instructions to work out a case for lawyers and diplomats to tiuker over and botch. I was to get the data as to the life history of the fur seal by observing that life on the ground, and to make as full a collection of the shins, skeletons, etc., as the circumstances of my living on the islands would permit.

I was received in the most cordial manier on the islands by both Government and lessee agents; every facility given me to work, and eversthing that I questioned or inquired into was answered and opened in perfect gond faith and to the best of the ability of those men. I quickly made myseif acquainted with enough of the Russian langriage so that I could freely get the personal ideas and iacts possessed by the Aleuts or natives bearing on the seals, thus checking my inquiries from one person to another. I never was misinformed by design, and by so doing never permitted myali to be deceived on that score. I devoted three consecutive seasons, 1872, 1873, and 1874, to close biological study of the fur-seal life, spending the winter of $1872-73$ on the islands so that I could see with my own eyes the entire routiue of arrival and departure of the seals from their haunts on the islands. The result of these studies was first briefly epitomized and published by the Treasury Department in 1874, and finally, when I found that I could not arwage my private affairs so as to permit of a two years' absence from home in order to study the Russian herd, I gave my elaborated work of $1872-187+$ to the late fen. Francis $\mathrm{A}$. Walker, at his solicitation, with the sanction of the Smithsonian Institution, for publication as rne of the initial monographs of the Tenth ('ensus. United States oi America.

In this monograpl it hecame imperative to omit much detail in the line of my record of daily observations on the rokeries, because it it were all incorporated the volume would be too bulkt, compared with the other monographs alsead, for the funds of the (ensus ()ffice to print; therefore my original colored rookery maps and hundreds of notes and illustrations, carefully drawn from life. were exclicled very reluctantly by the authorities, and only then because they believed that I had covered the ground fully, even in their abridged form. Whlen I suggested to Prof. Baird that all of the details of my chanter on the census of the seals-pietures, mans, and all-should be incorporated, he replied, sayir g that I had made it clear enough and easily understood in the abridged version.

Repeatedly, since the publication of that monograph in 1882, has this question of the population of the iur-seal rookeries on the Pribilof Islands been raised in my presence by naturalists of far greater ability than Dr. Jorlan, and I have never failed to satisiy them of the substantial soundiess of my riews and figures. Now that 
Dr. Jorkan at this late hour attempts to impeach their integrity I propose to impale his sophisms, assumptions, and misstatements on a few pointed facts.

Dr. Jordan says (p. 77): "The next attempt at enumeration was made in 1872-1874 by Henry W. Eiliott, special agent sent by the United States Treasury Department to investigate the condition of the herd. He followed the same general method inaugurated by Capt. Bryant, finding the shore extent and width of the rookeries and allotting a certain space to each individual animal. He, however, worked out the plans in much greater detail." This is a deliberate missatement of fact. Capt. Bryant made an estimate in 1570 of the area and extent of the breeding grounds of the Pribilof Islands, when, at the time, he had never laid his eyes on a single rookery on St. George Island and had seen but three of the seven breeding grounds on St. Paul, and these he saw through a telescope from the deck of a steamer. He then made the assertion that "there are at least 12 miles of shore line on the island of St. Paul, occupied by the seals as breeding grounds, with the average width of 15 rods. There being about 20 seals to the square rod, gives $1,152,000$ as the whole number of breeding males and females. Deducting one-tenth for males leares 1,037,800 breeling females." He then proceeded to estimate the St. George seals at "about one-half the number of St. Paul."

By the very nature of things this estimate was a mere guess. The author of it never saw one-hundredth part of the area he figured on, and he did not know enough of the animals, and, for that matter, nerer knew enough to understand that placing 20 of them on a square rod of superficial area was a ludicrous expansion of their real method of hamling on the breeding gromnds. It was the frank and good-natured personal admission of the old man. Bryant, to me. when I went up with him on the same steamer to the islands in April, 1872, that he did not know anything definite about the subject; that he was merely guessing, as any old whaler might calculate "clead reckoning" in a fog, that caused me to sei so promptly to work when I arrived, on a preliminary topographical survey of the area and position of each breeding ground on the islands, as well as making survers of the entire shore lines of both. But I had no idea as I began the work and completed it, in so far as the landed area went, of making a census of the seals upon the line of Capt. Bryant's speculation, because I early saw that there rere so many variations in the sizes of the seals, the irregular massing and unmassing of the harems, that the plan of locating just so many adult seals to a given area was impracticable.

But as I hung over these rookeries day aftel day I became impressed with the fact that no matter whether the mother seals were present on the ground or absent on their food excursions their pups, or young mes, never left the immediate area of their birthplace on the rookery up to a time in the season not later than the loth or 20th of each July; that if I counted them in a given area cluring that period I should then know just how many cows belonged to it, and only by taking the pups as my guide could I get at the real number of iemales. The males were steadiastly on the ground all the time, and then a general estimate for the number of virgin females could be made upon the ratio of this pup count, as it was a hasis of the birth rate of the entire herd.

While this subject grew upon me, I called the attention of my associates on the island (St. Paul, 1872-73) to it. One of these gentlemen. Mr. William Kapus, was an unusually well-educated man (the company's general manager), and a man of affairs as $\pi$ ell. He took deep interest in the solution of this seal-space problem as I presented it to him in the following form; also Dr. Kramer, the surgeon, another cultivated, scholarly man, aided me in the inquiry:

1. The seals haul out on these breeding grounds with great erenness of massingnever crowded unduly here, or scattered there-so evenly that if suddenly every mother were to appear at the height of the season there would be just room enough for all, without suffocating or inconveniencing their lives on the rocks.

2. That in estimating the number of seals in the breeding grounds we must make the number of pups present at the height of the season the unit of calculation, because their mothers are never all present at any one time. not half, and at many times not one-thirl of them are; that the height of the breeding season is between july 10 and 20 annually.

Upon these two fundamental propositions I stirred up a vigorous discussion and examination as to their truth or untruth among the white men then on the islands, or South Island especially, late in 1872, and until the close of the season of 1873 the settlement of this question was left open. Then each and every white man on the islands at that time (there were nine of them) sinscribed heartily to the truth of these, my assumptions, as a true working hypothesis.

Now, what cloes Jordan say about this particular law of even distribution on the rookeries which I formulated in 187?? Before I quote him I want to say that Jordan, 
when he landed on the Pribilof Islands for the first time in his life, July 8, 1896, saw nothing but a ghostly remnant of the life I was observing and studying in 1872-1874; the few seals that have in declining generations survived and were waudering about over the edges of those immense areas of cleserted hauling grounds of 1872 , and had ranged themselves in widely scattered and irregularly massed harems on fringes of the abandloned rookery slopes of 1872 , became to his inexperienced eve "a great many thousands" and "a strong nucleus." Never having seen what I saw, he became deeply impressed with the form of what only aroused my pity in 1890, as it had stimulated iny wonder and admiration in 1872-1874. With this wretched understanding and loaded to the gunwale with it, Jordan says in regard to my basic proportions as above cited:

"One who is familiar with the nature of the breeding grounds can not help feeling that in the foundation of this law Mr. Elliott did not have the picture of the rookeries before him. Had he traveled over the length and breadth of the rookeries, as was done in 1896 and 1897 , he never would have proposed such a law; that there should be as many seals to the square rod on the jagged and broken lava rocks of Kitovi or on the broken slopes of Gorbatch, where the animals are now, and must have then been separated by bowlders weighing tons, should be the same as on the smooth sand flat of Tolstoi or the level slope of Hutchinson Hill is, on the face of it, impossible."

Just because I had traveled over these rookeries day in and day out, when seals were there and when absent, was why I recognized this law of distribution, and I will safely venture to say that I have taken two steps to Jordan's one in this work on the rookery grounds; with every fissure and imbedded lava rock (these loose "bowlders weighing tons" on Kitovi and only few such "bowlders" on Gorbatch), I am familiar, and I found to $\mathrm{my}$ surprise, at first, that Kitovi was an ideal massing ground for the breeding seals, and Gorbatch also; that these jagged rocks nearly all deeply imbedded in the detritus of the cinder and lava slopes, carried more seats than if they were perfect plane surfaces. Wherever I found a miniature lava butte on these breeding grounds (they are all of volcanic superstructure) that the seals could not scale or otherwise occupy, the area of the same was deducted from the sum of square feet belonging to the ground, and I never made the "blunder of assuming the same distribution everywhere," by taking this precaution, and in the following way: First, I carefully located the herls as they lay on the several breeding grounds during the height of the season, i. e., between July 10 and 20 , which I liscovered to be the time in 1872 , this location Was rapidly and accurately made on a land chart of the rookery ground prepared early in the season and before the seals had hauled out. By having these charts all ready, with the stations from which my base lines and angles were taken, all plainly in my view when the seals hauled out, it was a simple thing to place the bearings of the massed herds on the chart; the reef and Gorbatch grounds made a busy day's work, and no more for me, because thus prepared; the same of Zapadnie. Tolstoi easily finished in half a day; same of Lukannon, same of Kitovi, Polavina a short day's work, while Novastoshals, or the large Northeast Point breeding ground, took the best part of two days. The St. George rookeries were handled in even shorter time by this method.

Not content with assuming that I had not traveled over the rookeries as he had, Jordan proceeds to ignore the written record of my work in regard to counting the pups. On page 79 of his report he makes the gratuitous assertion that I did not know that all the breeding seals were not present on the rookeries at any one time during the height of the season. Mark his language, which my published work in 1880 disproves every word of: "But of these things, Mr. Elliott was not aware. He was content to assume that all the cows were there.'

What do I say about these cows, published 16 years before Jordan ever saw a cow seal and then for the first time on the Pribilof rookeries? "The females appear to go and to come from the water to feed and bathe quite frequently after bearing their young, and usually return to the spot or its immediate neighborhood, where they leave their pups." * * * Again I say, "A mother comes up from the sea, whither she has been to wash and, perhaps, to feed for the last day or two." * * * (Mínograph, Seal Islands of Alaska, p. 39; Washington, 1880.) And still worse for Dr. Jordan, on pages 104 and 105 of the same monograph, Fish Commission edition, 1882, appear's the still more explicit proof of his deliberate inability to give credit to truth. What better impalement of Jordan can be devised than these words of mine: "The umbilicus of the pup rapidly sloughs off, and the little fellow grows apace, nursing to-day heartily, in order that he may perhaps go the next two, three, or four days without another drop from the maternal fount; for it is the habit of the mother seal to regularly and frequently leave her young on this, the spot of its birth, to repair for food in the sea. She is absent by these excursions, on account of the fish not coming in-shore within a radius of, at the least, 100 miles of the breeding grounds, through intervals varying, as I have said, from a single day to three or four, as the case may be." 
And with this published record of my thorough understanding of the truth that the cows are not present all the time, as early as $1572-1874$, in his hands, Dr. Jordan deliberately attempts to rob me of that credit which naturalists all orer this world have given to me and still gire for my accurate rork on these islands. I say. "he attempts," and I say it advisedly, for that is all it amounts to.

From this unjustifiable misrepresentation Dr. Jordan proceeds to make an analysis of my figures of the population of the seal rookeries, as published in $1872-1874$ and enlarged upon by me again in 1850 . Now he steps upon ground of legitimate criticism, and I am more than ready to meet $i t$. With reference to my figures (Nonograph, Seal Islands, p. 61), he says: "Waiving for the moment the method of obtaining these figures, we may remark that they are not easy to understand. Of this total 'of breeding seals and young,' Mr. Elliott in the same connection tells us that 1,000,000 'are youmg.' There must then be an equal of mothers, or 2,000,000 adult breeding females and their pups. To this must be added the young 2 -year-old cows that are included, though not present. Ir. Elliott has himself given us an estimate of these. Considering of the $1,000,000$ pups born 500,000 are females, he says, 'that at least 225,000 of them safely return in the second season after birth.' This, therefore, gives us a tatal of $2,225,000$ females and young in the complete estimate of $3,193,420$, leaving 868,425 animals which can only be accounted for as breeding bulls. This is imposible, and yet no other explanation of the discrepancy is at hand."

This is exactly quoted as it stands in Dr. Jordan's final report, page 79 , and if it were not for the deliberate misstatement that "IIr. Elliott in the same connection tells us that 1,000,000 "are young" " there might indeed be "no other explanation of the discrepancy" at hand. But "in the same comnection" I do not say anything of the kind about only 1,000,000 pups being born out of this grand total on the Pribilof Islands; on the contrary, on page 61 (Monograph, Seal Islands), I present a carefully tabulated statement of the exact ratio of seal life on the several breeding grounds of the Pribilof Islands, summing it up by the square feet of sea margin, multiplied by the arerage deptli as "grand sum total for the Pribilof Islands (season of 1873), breeding seals and young, $3,193,420$." saying as I do so, that these figures as above, show this total. Then I proposed to open another and distinctly separate enumeration of the nonbreeding, or bachelor seals, which I clearly declare entirely ontside of any basic calculation, having no initial point, like the breeding seals; and 1 close this summary of the seal life on the seal islands on the following page.

Then I take up under an entirely different caption an entirely different question. I take up then the question of "The increase or diminution of the seal life, past, present, and prospective." I enter upon a purely speculative theme, and do not attempt to speak except in broad, general terms. Taking up that subject in this connection, and not in conjunction with the statement of facts preceding it. I enter upon a hypothetical expression of what I believe the loss of life sustained by the young seals amounts to. I use the broad, general assertion that " $1,000,000$ pups, or young seals, in round numbers," are amnually born upon these islands of the Pribilof group every year." Naturally to point my speculation in figures of loss, which follows, it is better and easier to say " $1,000,000$ " than $1,296,710$, which would be the exact line of figures if the speculation was treated as a matter based upon fact. But I merely assume that half of the pups get back as yearlings next year, and that assumption is as well or better illustrated by a general figure than a specific one. The result is precisely the same anyway, and really has in either case of exact or general figures the same value. In my own mind at the time I was inclined to think that fully one-half of these pups did not get back, and so I preferred the general or indefinite figure rather than to strain an exact division of the pups into a vague theory. Jordan himself is guilty of this fusion of fact and theory repeatedly in this report. But I never have permitted it in my work.

Dr. Jordan proceeds to make himself still more emoneous in assumption. He says: "But if these figures were in themselves reasonable we must still take exception to the method by which they were obtained. * * * On his method of surveying the rookeries, Mr. Elliott has given us practically no data."

The stupidity, or else the effrontery, of this statement as to my giving him no data can be well understood by reference to the claborate charts of these breeding grounds which are published in my report of 1890 . (H. Doc. No. 175, 54th Cong., lst sess.) These surveys were so elaborate and so full of detail that Gen. Walker in 1950 was unable to publish them in the Census Monograph, owing to lack of funds for their preparation, and I rehetantly inserted a small series of indeterminate pen-and-ink sketch maps to ilhustrate the general idea, but in 1890 I took them up to the islands with me and placed my work of that season on them in turn, making in this way the very best contrast of the condition of $1872-1874$ with that of 1890 that could lave been devised. 
Unlike Dr. Jordan, I am not a barber's apprentice in topographical work. I served three summers under the best of topographers in the ficld, 1869-1871, inclusive, doing exactly such work as this on the seal islands; i. e., making original survers of unmapped districts in the Rocky Momntain region. Until I made my survers of the seal islands, in 1872-1874, there was nothing on the maps that faintly resembled the area, the contour, or the topography of the Pribilof group. The Rivsian charts of them were periect caricatures and the American copies no better.

So good were my charts of St. Panls Island that a surveying party of the United States Coast Survey, when it landed there in July, 1874, asked for and received from me copies of it, which they did not alter in the slightest noteworthy degree after spending a week on the ground, and it was shortly after published by the Coast Survey Office, with scant credit to me, its author. However, I care nothing for that, and I only mention it because Dr. Jordan calls in one of his subordinates to appear as a swift witness against me as a surveyor. Jordon says: "Ot these maps (apt. Moser, in his hydrographic report on the islands, made certain tests. Of Mr. Elliott's shore line he says: 'It was a bad misfit and rarely stood the test of an instrument angle.' He further says of the topography of the maps that 'it is so vague and indefinite that it is next to impossible to do anything with them. I should call them sketches.'

It will do Jordan good and take the conceit out of this (apt. Mosel to know that these charts of mine stood the test of instrument angles to the entire satisfaction of Capt. J. G. Baker, L'. S. R. M., and Lieut. (now (apt.) Washburn Maynard, U. S. X., in 1874, and (apt. Colson, U. S. R. M., in 1890. Each and every one of those trained hydrographers expressed their approval of these charts and their surprise at the aceuracy with which I had plotted the shore lines. Capt. Maynard, in 1S74, went all over the rookeries with my detailed charts of the same, made in $1872-73$, and between us, there, we verified and corrected every one of them, so that these records which I made in those years can not be whistled down the wind by any inexperienced or jealous man or men.

Following this attempt to destroy the sense of my chart work (on p. 80), Jordan raises a question, and then answers it, as usual, wrong. He says: "To each one of the 7 of the 10 rookeries of St. Paul Island Mr. Elliott ascribes an average width of 150 feet. Two of the remaining breeding grounds have an average wilth of 100 feet each and the third 40 feet. * * * Ti hatever the average width of each rookery may have been, it was certain it was not the same for all. Neither now nor at the past times Tolstoi, Polovina, Vostochin, the Reef, Kitovi, Lukannin, and Zapadin had the same average width. The 150 feet is a g'uess and that only.'

A guess, and that only! Indeed. The utter ignorance of the method of my work which Dr. Jordan assumes, or really is afflicted with, can be well understood when I take up, for instance, the case of Tolstoi, to show how easy it is for certain people, like Jordan, who, having ears, hear not; and eyes, see not. On page 38 of my 1890 report which was in Jordan's hands when he first started ior the seal islands, appears the following letailed explanation of each and every step taken by me in surveying each and every rookery as well as Tolstoi:

\section{Detailed analysis of the survey of Tolstoi rookery, July 10, 1910.}

[Sea margin beginning at $\mathrm{A}$ and ending at D.]

Square feel. 64,000 400 feet sea margin between $B$ and $C$, with 60 feet average depth, massed .... $\quad 24,000$ 1,600 feet sea margin between $C$ and $\mathrm{D}$, with 10 feet average depth, massed .. $\quad 16,000$
Jag E has 300 feet of depth, with 40 fect average width, massed.......... 12,000 Jag $F$ has 100 feet of depth, with 40 ieet average width, massed . . . . . . . . 4,000 Jag G has 120 feet of depth, with 40 feet of average width, massed . . . . . . . . 4,800

Total square feet................................... 80.

The annexed colored chart ${ }^{1}$ that this legrend illustrates earries all these stations and base line points in detail. Every topographical feature is faithfully indicated on it, and these specialized lines of average depth were drawn over these sections of the herd as it lay upon the ground on that day and date - the proper time of the season.

Now, in order that this detailed analysis of Tolstoi can be summed up in one compact sensible expression I take the entire length of its sea margin, 2,800 feet, and divide the entire sum of its square feet of massed area, 124,800 feet, by it; that 
enables me to say, "July 11, 1890 , Tolstoi has 2, 800 feet of sea margin with $44 \frac{1}{2}$ feet of average depth-124,800 square feet of superficial area, making ground for 62,400 breeding seals and voung."

Here is the result in detail of my survey of Tolstoi in 1572 , which was verified by myself and Capt. Mashburn Maynard, United States Navy, in 1874:

\section{Detailed analysis of the survey of Tolstoi rookery, July 15, $18 \% 2$.}

[Sea margin beginning at $\mathrm{A}$ and ending at D.]

Square feet.

1,000 feet sea margin between $A$ and $B$, with 350 feet average depth, massed. . 350,000 400 feet sea margin between $B$ and C, with 150 feet average depth, massed.. 60,000 1.600 feet sea margin between $C$ and D, with 30 feet arerage depth, massed... 48,000

Three thousand feet sea margin on Tolstoi breeding around and 458,000 square feet in it, making ground, in round numbers, for 225,000 seals.

It will be noted that in this Tolstoi summary for 1872 I ignore the real presence of 8,000 square feet, and deliberately reduce that estimate of seals from 229,500 to 225,000 , because I never ran the risk in my work of 1872 and 1890 of being a foot or two ahead of the real average. I carried this cautious reservation all through my surveys of each and every rookery, and this is the reason why Capt. Maynard, my associate in the work of 1874 , makes his estimate, based upon this survey, of the sum total of Pribilof seal life so much higher than mine. He declared that he was satisfied from close personal supervision of taking all our land angles in $187+$ that I was safely inside of the real limit of supervision and that the figures of the survey were couservative and right. He was then, as he is now, a skilled mathematician and hydrographer, and he had the right to his opinion based upon the figures of that careful work. Yet Jordan has the sublime impertinence in 1895 to sneer at this unbiased, careful survey of $1872-1874$, by saying "the 150 feet is a guess, and that only.". (P. S0, note.)

I used these figures of 1890 in detail for Tolstoi because I do not give the detailed analysis or figures of $1572-1874$ (only the summary) in my 1890 report of its sea margin and square feet, viz, "3,000 feet of sea margin, making ground for 225,000 breeding seals and their young," not deeming it necessary to produce so many detailed figures when my charts for both seasons were in full evidence in the published work of 1890 .

As with Tolstoi, so with every other rookery on the Pribilof Islands. But Jordan, holding all this incontestible proof of careful survey in his hands, can not "verify Mr. Elliott's surveys of the rookeries."

Jorclan also, in this connection, has been careful not to quote the reason why I made these elaborate charts in $1872-1874$. If he did, he would render lis mcthod of counting the seals, or rather guessing at the exact comt of individual bulls, cows, and pups, idle and abortive. I said in 1874, speaking of $\mathrm{my}$ law of uniform distribution of breeling seals on the rookeries: "This fact being determiner, it is evident that just in proportion as the breeding grounds of the fitr seal on these islands expand or contract in area from their present dimensions, the seals will increase or diminish in number." How well my charts of 1890 , laid upon those of 1872-1874, tell that story. How futile the rambling and self-contradicting seal-counting work of Jordan to express the truth. Listen to Jordan himself, on page 101. He unwittingly trips himself there on this very point: "The only reliable basis of enumeration has been found and determined. This is a count of live pups." (This is what I published in 157-1574.) Then on page 341. part 2, Jorclan hamstrings himself in the following language: "It is eviclently impossible to make an accurate census of the seals on St. Paul Island, because on the great rookeries, as the Reef Torbatch, Tolstoi, and Zapadin, no one can either estimate or count the cows (sic); nor ('an one do it at Polovina, because there is no one point of view where the whole rookery is visible; even the bulls can be only roughly estimated." Very true, Dr. Jordan; but why does Dr. Jordan, on page 3.3 , part 1, call in this remarkable witness to his own inability to reason on his own lines of argument? "In the same year (1879) Mr. Beaman recorls, under date of Jume 10, that 'there were a couple of thousand bulls' ou Polovina rookeries, when IIr. Elliot estimates fully 10,000 in 1874."

I never made the hlunder of attempting to comt all the bulls, all the cows, or all the pups on any rookery in 1872-1874. The utter stupidity of such a step ncver entered my head. It never did in 1890 , even when the ragged remnant of the great life of 1872 was before me. It has only remained for Jordan and his job lot of assistants to race $u p$ and down these desolated breeding areas, in their idle attempts to do so, and the record of the seli-contradiction of their own work bristles with the folly of it on a score of pages in his report.

I can not ask for space here to express the rapid succession of erroneous assumptions and studied misstatements which are strung on the wire of this report-that I 
shall gain later-but I will pick Dr. Jordan up on one more point, in conclusion. On page $80 \mathrm{Dr}$. Jordan says: "But aside Irom the question of accurar $\mathrm{Y}$ in the survers themselves, Mr. Elliott has assigned an impossible space to each individual scail. His unit of space is 2 square feet to each animal, young or old, or 4 srfuare feet for the cow, ignoring the pups. * * * In a standing position she (the cow) would need at least 3 square feet. but as the cows are constantly moving about and coming and going to and from the sea, it is impossible to limit one to such sprare."

At this point, and in this connection. Jordan may be pardoned for his inability to understand the massing of the breeding seals in $1872-187+$. when there were seven to ten times as many of them as contrasted with their number when he first saw them in 1896. In 1890, when I landerl on the seal islands after a rontinuous absence from them for 16 years, the sight of their abandoned and shrunken grounds impressed me instantly; not so were the newconiers, the Treasury agents who traveled up with me; they, like Jordan, only saw " thousands of seals-many thousands," and it was really hard to get them to appreciate the gravity of the condition of the herd. I told them on the 1st of Jume, 1890 , that they would not get the quota of 60,000 , and not a man. agent of company or Treasury. or a native. for that matter, then agreed with me on the islands. But by the end of the month they saw the truth as I had cleclared it.

Here is what I published in $1872-1874$. relative to the seal unit of space, and it is clear enough to men who have reasoned to the line with me on the ground itseli; to men like Capt. Maynard. Uniterl States Navy, 1874, and II illiam Kapus, general manager of the lessee in $1572-1873$, and all of their official associates who were with them at that time:

"Rooliery space oecupied by single seals. - When the adult males and females, 15 or 20 of the latter to every one of the former, have arrived upon the rookery, I think an area a little less than 2 feet square for each female may be considered as the superficial space required by each animal with regard to its size and in obedience to its habits; and this limit may safely be said to be over the mark. Now, every female or cow on this 2 feet square of space doubles herself by bringing forth her young, and in a few days, or a week, perhaps, after its birth the cow takes to the water to wash and feed and is not back on this allotted space one-half of the time again during the season. In this way is it not clear that the females almost double their number on the rookery grounds without causing the expansion of the same beyond the limits that would be actually required did they not bear any young at all? For every 100,000 breeding seals there will be found more than 85,000 females and less than 15,000 males; and in a few weeks after the landing of these females they will show for themselves-that is, for this 100,000 -fully 180,000 males, females, and young, instead, on the same area of ground occupied previously to the birth of the pups.

"It must be borne in mind that perhaps 10 or 12 per cent of the entire number of females were yearlings last season and come up onto these breeding grounds as nubiles for the first time during this season--as 2-year-old cows. They, of course, bear no young. The males, being treble and quadruple the physical bulk of the females, require about 4 feet square for their use of this same rookery ground; but as they are less than one-fifteenth the number of the females-much less, in fact-they therefore occupy only one-eighth of the space over the breeding ground, where we have located the supposed 100,000 . This surplus area of the males is also more than balanced and equalized by the 15,000 or 20,000 2-year-old females which come onto this ground for the first time to meet the males. They come, rest a few days or a week, and retire, leaving no young to show their presence on the ground.

"The breeding bulls average 10 feet apart by 7 feet on the rookery ground; have each a space, therefore, of about 70 square feet for an average family of 15 cows, 15 pups, and 5 virgin females, or 35 animals for the 70 feet-2 square feet for each seal, big or little. The virgin females do not lay out long, and the cows come and go at intervals, never all being on this ground at one time, so the bull has plenty of room in his space of 70 square feet for himself and harem.

"Taking all these points into consideration, and they are features of fact, I quite safely calculate upon an average of 2 square feet to every animal, big or little, on the breeding grounds at the initial point upon which to base an intelligent computation of the entire number of seals before us. Without following this system of enumeration a person may look over these swarming myriads between Southwest Point and Novastoshnah, guessing vaguely and wildly at any figure from 1,000,000 up to 10,000,000 or $12,000,000$, as has been done repeatedly. How few people know what a million really is. It is very ( asy to talk of a million, but it is a tedious task to count it off, and make\$ one's statement as to 'millions' decidedly more conservative after the labor has been. accomplished.

"I am satisfied to-day that the pups are the sure guide to the whole number of seals on the rookeries. The mother seals are constantly coming and going, while the pups

$11864-13-3$ 
never leave the spot upon which they are dropped more than a few feet in any direction until the rutting season ends; then they are allowed, with their mothers, by the old bulls to scatter over all the ground they want to. At this date the compact system of organization and massing on the breeding grounds is solidly maintained by the bulls; it is not relaxed in the least until on and after July 20." [Transcript from the author's field notes of 18\%4. Nah Speelkie, St. Panl Island, July 12.]

Now, with this life study before him, proportioned to the exact attitudes, sizes, and disposition of a harem of fur seals, what does Jordan say? Hear him: "It is true that $\mathrm{Mr}$. Elliott justifies in part his small unit of space by certain references to the coming and going of the animals. He asserts that after the pups are born the 'individual cows are' not on their allotted space one-fourth of the time, and that the females 'almost double their number on the rookery ground without expanding its original limits.' But Mr. Elliott failed to grasp what this really meant. He sees in it only justification for the unit of space, which he has assigned to the individual animals. It should have called his attention to the fact that the breeding seals which he saw before him, and which he was attempting to enumerate, were but a part and not the whole of the rookery population.'

It seems utterly incredible that any man with the least regard for the express command of writien directions like those which I have published, as above quoted, could make such a ridiculous and senseless reductiou of them. Dr. Jordan has, however, done so, and here we have the evidence of his weakness in cold type.

In closing I can fitly say that the shame and ruin which overtook our cause of the fur seals at Paris in 1893 was no sin of mine, and the continuance of that shame and mummery of shallow experts on the rookeries in the Treasury and in the State Department up to the close of Jordan's work in 1898 was also against my protest. Now that the curtain has rung down on this last seal commission farce of our Government, with its harlequin show of branding baby fur seals on the islands, "perfect agreement" with England, and searching the seal sacks of our returning women from Canada and Europe in New Tork, all to the utter indifference of the pelagic sealer, whom the business was to hurt, it is to be hoped that a further confession of this impotence of our people to meet the Canadians in open argument for some method of saving our fur-seal herd from indecent and cruel slaughter may be avoided.

The responsibility for the ruin of the Pribilof herds primarily belongs to Benjamin Harrison, James G. Blaine, and the two Fosters-"ex-Gov." Charles and the "Hon." John IV. We had an admirable case and abundant information at our command, but the two Fosters (par nobile fratrum!) ignored it, and put the whole question into the hands of vaporing lawyers and ridiculous experts. The gave us the absurd Paris "regulations" in 1893.

The steady contjnuation of this scandalous order on the seal islands since has been made by the indifference of Grover Cleveland and the wretched egotism of Richard Olney (had Gresham lived the tables would have been turned), ably supplemented by the present administration.

The whole business since 1890 has been a scaulal in our clepartments and an imposition upon the taxpayers of the Uuited States.

LAKEWOOD, OHIo, September 20, 1899.

HenRy IV. ElliotT.

Mr. Ellotot. It was this publication, as above, which opened the eyes of Secretary John Hay and caused him to agree with my proposal made to him April 2, 1900, per Hon. Theodore E. Burton (my Representative), aud which led to my engagement with him of A pril 30-May 3, 1900, by which the act of April 8, 1904, was secured by my initiation, and by which authority he reopened this fur-seal case with Great Britain April 16, 1904, with me as his adviser and expert in the premises.

In hearing No. 14, pages 1000-1001, July 30, 1912, House Committee on Expenditures in the Department of Commerce and Labor, appears the following relation with regard to the census of 1872-1874:

Mr. Elliotт. During the hearing of the Senate Committee on Territories on "General conditions in Alaska," February 23, 1912, I was called upon by the chairman, Senator William Alden Smith, to inform the committee low I made my enumeration of the fur-seal herd in 1872-1874, and the following statement and inquiries were made, to wit (pp. 17, 18, 19):

"Senator Hгтсноск. Are they unable to count the seals there?

"Mr. Wrisson. I could not really answer that question.

"Senator ChamberLain. I do not see how they could count them.

"Mr. Wruson. It is a difficult matter to count them ou the rookeries. 
"The Chatruan. I am going to ask Mr. Elliott if it is a difficult matter to count them; he is an expert on the subject.

"Mir. EliotT. They can not be counted.

"Senator NeLson. What is the amount of the herd now?

"Mr. Elliott. Nobody knows definitely. There may be 50,000, there may be 60,000 , there may be 100,000 . There is just a little thin line of life left.

"Seuator Nelson. What was the amount of the herd when the lessees took itthe first lease?

"Mr. ElliotT. Four million seven hundred and fifty thousand.

"Senator Shively. What year was that?

"Mr. ElLIOTT. 1872.

"Senator Shively. And now you say there may be 50,000 or 100,000 ?

"Mr. Elliott. Nobody knows.

"Senator Shrvely. Well, what is your estimate?

"Mr. Elliotr. My estimate is like theirs. I have not been up there since 1890.

"Senator Shively. Is it a mere guess, and is it possible that there has been no reduction?

"Mr. ElliotT. Since 1890?

"Senator Shively. Since 1872.

"Mr. ElliotT. Oh, no; no, indeed. We knew definitely-

"Senator Hrтchcock. You could count them, then, when you were up there, and found that there were $4,000,000$; why is it not possible that they can be counted now?

"Mr. ElliotT. I did not count them. I surveyed the area of the breeding grounds upon which they rested, that area being definitely ascertained by a plane table survey. Into that superficial area I multiplied a composite unit of calculation. These seals in lying upon this ground obeyed the natural law of distribution-so many to a given area, never more here nor there, but uniformly distributed over this area, whether it was large or small. That area being ascertained by a plane table surveya topographical survey-I multiplied into that superficial area a unit of space occupied by the composite seal, and that gave me 4,700,000.

"The Charruan. For whom were you acting then?

"Mr. Elliotr. The Smithsonian Institute-tle Government.

"The Chairman. Under whose anthority?

"Mr. ElliotT. The Secretary of the Treasury.

"Senator Hiтchсоск. Is that the only time you have ever estimated them?

"Mr. Elliott. The second time I took the subject up was nearly 20 years laterin 1890 .

"Senator Hгтchсоск. And what did you find?

"Mr. Elliott. I applied the same system, and I found 959,000 .

"Senator Shively. As against 4,000,000 on your first survey?

"Mr. ElliotT. Yes. And since then they have been shrinking and shrinking. and the London sales show in the last six or seven years that they have been killing nothing but the dregs: there is practically nothing else left.

"Senator NelsoN. What is your opinion about land killing?

"Mr. Elliott. The land killing is primarily responsible for the destruction of the herd. I brought the proof-overwhelming proof-before two committees of Congress.

"Senator NELSON. That is the conclusion of the subcommittee which went up there in 1903; we came to the conclusion that they not only ought to stop pelagic sealing, but all land killing, in order to restore the herd.

"Mr. Elliott. Yes, sir.

"Senator Nelson. Did not the Russians adopt that course?

"Mr. ElLrotT. Certainly. They were compelled to do it. When there was no pelagic killing of the herd, they destroyed the herd by the same methods we employ to-day.

"Senator Nelson. For how long did they prohibit killing?

"Mr. ElliotT. Ten years.

"Senator NELSON. And that restored the herd?

"Mr. Elliotr. Yes; although not to its full capacity.

"Senator NeLson. At that time, when the Russians took that course, there was no pelagic sealing?

"Mr. Ellotт. They had never heard of it.

"Senator NeLson. It was all land killing?

"Mr. Elliotr. It was all land killing.

"Senator Nelson. And yet the Russians found it necessary to stop that altogether to restore the herd?

"Mr. ElliotT. Exactly. They were killing the male seals, as we have been doing for 20 years. 
"Senator NELSON. What was the age of seals killed last year?

"Mr. ElLiott. They were mostly yearlings.

"Senator Nelson. What is the proper age to kill them?

"Mr. Elliotr. They should not be killed under 2 years of age.

"Senator NELSON. And most of those killed last year were yearlings?

"Mr. ElLiotт. Indisputahly so. It is all a matter of evidence.

"Senator Shrvely. And when the Russian Gorernment again allowed seal killing they put strict limitations on the land killing?

"Mr. Elliott. They had autocratic power, hut their experience taught them to put that limitation on them.

"Senator SHrvely. But they did-

"Mr. Ellotw. Yes. they dirl; and they so preserved the birth rate by allowing the necessary number of males to keep up the herd.

"The Charman. You may go ahead with your statement, Gov. Clark."

In closing this topic, it is in order to submit an exhibit of the facts which show us the cause of that commercial ruin of our fur-seal herd which we now observe on the Pribilof Islands.

If it were not for these records elaborately and systematically made on those desolate hauling grounds, which Elliott published in 1874 and 1890 , it would be fairly impossible to get an adequate idea of what an immense herd of fur seals was in existence when we took possession of Alaska in 1867 .

Then, when that idea is crasped, and it is made clear that ever sinee 1857, up to the hour of 1867 when the herd became ours, this wild life had remained at about a steady annual number of 4,700,000 seals of all classes, we ask: What have we done to reduce it, so by this year of 1913 all that we find surviving of it are only 190,555 seals of all classes?

Why did we lose this herd, when the Russians easily kept it from 1857 to 1867 in that fine form and number?

The answer is made easy in the light of the following facts:

$\bar{I}$. It is a fact of indisputable record that the Russians never killed or disturbed the female seals on the rookeries of St. Paul and St. George Islands from start to finish of their possession of them.

II. It is a fact of indisputable record that from $1786-87$ up to 1800 the Russians annually took from 120,000 to 60,000 young male and yearling seals from these hauling grounds, and during all that time never took any seals at sea nor were these seals taken at sea by any other people, save the few annually secured by the Northwest coast Indians.

III. It is a fact of indisputable record that the Russians, beginning in 1800 with an annual eatch of 40,000 young male seals and yearlings, by 1817 had the greatest diffieulty in getting that number then, and notes of protest against the killing on the islands were sent to Sitka by the earetaker, Kazean Shaishnikov, of St. Paul Island, urging the governor of the R.A. Co. to rest the seals from killing for a term of years. No pelagie sealing was known to the Russians during this period of any kind.

IV. It is a fact of indisputable record that while the protest of Shaishnikor was noticed favorably by the gorernor, yet the directors of the R. A. Co. at St. Petersburg did not consent; that they renewed their orders to kill, and sent one of their number, Gen. Yanovsky, out from St. Petersburg in 1818 to the seal islands, charged with the business of examining into the cause of this loss of surplus male life on the islands. 
$\mathrm{V}$. It is a fact of indisputable record that Yanovsky, in 1820, after spending the entire season of 1819 on the Pribilof hauling grounds and rookeries, made a confidential detailed report which declared that this immense decline in the life of the fur-seal herd was due entirely to the annual killing of all of the young male seals and yearlings which the drivers of the company could secure; he urged a complete cessation of it for a term of years.

VI. It is a fact of indisputable record that this request of Gen. Tanovsky was ignored by the directors, and the orders to get all of the young male seals and yearlings were annually renewed; 1 and

VII. It is a fact of indisputable record that at the end of the season of 1834 , instead of getting 20,000 holluschickie, they secured, with the "utmost exertion," only 12,000 "small" (yearling) seals; and that with the end of this season's work the herd was so reduced that the directors were obliged to order a 10 year's' rest to all commercial killing on the islands, which went into effect in the summer of 1834, and was faithfully enforced; so that by 1844 commercial killing was resumed of a relatively small number, beginning with 10,000 to 13,000 , increasing gradually annually up to 1857 , when this herd rielded that year 62,000 "choice young male" seals, and the herd itself had regained its natural and normal maximum number, viz, from 4,500,000 to $5,000,000$ seals of all classes.

VIII. It is a fact that during all this period of decline and restoration of the Russian herd from 1800 to 1857 there was nothing known of, or hinted at, which is now so well known as "pelagic sealing."

IX. It is a fact that when we took possession of the herd we leased them to a corporation with a permit to take annually 100,000 young male seals, or 40,000 more every year than had been the average number taken by the Russian management since 1857 .

$\mathrm{X}$. It is a fact of indisputable record that by 1883 our lessees had great difficulty in getting their quota this year of 100,000 "prime" 3 and 4 year old skins; that they began to scour the hauling grounds for them, and increased the rigor of that search and driving annually thereafter.

XI. It is a fact of indisputable record that up to this time of first difficulty since 1870 , of getting annually 100,000 fine young malc seals, no pelagie sealing of the slightest consequence was in operation; only six or seven small vessels, busy for a few weeks in the year, off the Straits of Fuca and west coast of Vancouver Island, had appeared in the saa up to the opening of the season of 1886.

(1) Therefore, in the light as above clearly and fairly thrown by these records of past experience, we now know that the Pribilof herd

1 As Yanovsky's report was a confidential paper, and as such seen only by the board of directors, we have no details beyond those given out, as below, and taken from the records of the administrative office at Sitka. It is, however, very clcarly stated that the excessive killing of young male scals is the sole cause of the impending ruin of the herd, to wit:

"In his report No. 41, of the 25 th February, 1820, Mr. Yanovsky, in giving an accotmt of his inspection of the operations on the islands of St. Paul and St. George, observes that every year the young bachelor seals are killed and that only the cows, 'sekatch' and half 'sekatch,' are left to propagate the species. It follows that only the old seals are left, while if any of the bachelors remain alive in the antumn they are sure to be killed the next spring. The consequence is that the number of seals obtained diminishes every year, and it is certain that the species will in time bccome extinct.

"This view is confirmed by experience. In order to prevent the extinction of the seals it would be well to stop the killing altogether for one season and to give orders that not more than 40,000 are ever to be killed in any one year on the island of St. Paul, or more than 10,000 in any one ycar on the island of St. George.

"Mr. Yanovsky considers that if these measures are adopted the number of seals will never diminish.

The board of administration, although they concur in Mr. Yanovsky's view, have deeided not to adopt the measures proposed by him unless it is found that there is no migration of seals to the two small islands which are believed to exist to the south and north of the chain of islands. * * *" [Letter of the secretary of board of directors R. A. Co., St. Petersburg, Mar. 15, 1821, to Gov. Muraivev, Sitka, Alaska.] 
was reduced to the very same commercial ruin by 1834 which we now find our herd reduced to in 1913.

(2) And that this ruin of 1834, and again in 1913, was caused by the very same close killing annually of all the young male seals, and yearlings that could be secured by the greedy Russian contractors, and in turn by our lessees.

(3) And that the Russians, to save and restore the herd, were compelled to stop this excessive and improper killing in 1834, and sispend any commercial killing on the islands for 10 years thereafter, or up to 1844-1846.

(4) And that the experiment of ammully taking 100,000 choice young male seals, since 1870 up to 1890 , by our lessees, as against the habit of taking 60,000 annually by the Rtssian lessecs, was a bad one; and that this number of 100,000 "surplus male seals" was an excessive and destructive killing, which has led to a complete elimination of the breeding male life of the herd, as we see it to-day, and which policy, if continued, will surely exterminate the specics itself.

DR. JORDAN'S RECENT ATTEMPT TO SIIELD THE ILLEGAL AND RUINOUS KILLING ON THE SEAL ISLANDS BY THE LESSEES AND GOVERNMENT AGENTS SINCE 1896 TO DATE OF DECEMBER, 1912.

This anxiety to shicld the lessecs from any criticism or punishment for this illegal work of killing young seals has been carried by Dr. Jordan to the extreme limit of issuing through the Department of Commerce and Labor, by the consent and approval of Secretary Charles Nagel, a statement, on December 20, 1912, entitled "Economic Circular No. 4," with this preface, as follows, by Mr. Nagel:

TRUTH ABOUT THE FUR SEALS OF THE PRIBILOF ISLANDS.

[Department of Commerce and Labor, Bureau of Fisheries. Economic Circular No. 4, issued Dec, 20, 1912.]

A treaty was entered into July 7, 1911, by the United States, Great Britain, Japan, and Russia, intended to prohibit pelagic sealing. In August, 1912, an act to give full effect to the treaty was passed by Congress.

In view of these facts and of recent discussion as to the best method of management of the fur-seal herd, the department determined to have a careful examination and study made during the season of 1912. Mr. George A. Clark, secretary of the Fur Seal Commissions of 1896 and 1897, and special investigator on the seal islands in 1909 , was sent to the islands for that purpose. The following statement, drawn up by him and Dr. David Starr Jordan, commissioner in charge of fur-seal investigations in 1896-97, is based primarily upon Mr. Clark's investigations of the past season. It presents the important and essential facts so clearly that the department publishes the statement for the information of all who are interested in the fur-seal question.

Instead of telling Congress and the people to whom it was sent under the frank of the department the "truth," it has told nothing but untruth, and a few examples of the most flagrant and brazen untruths will be submitted, as follows:

STATEMENT OF DR. DAVID STARR JORDAN AND MR. GEORGE A. CLARK.

*

The fur seal is a polygamous animal. Steller, its discoverer, found it in a state of nature in families numbering $8,15,50$, and even 120 females to 1 male (p. 1 ).

This quotation of Steller, as above made by Jordan, who only saw these animals during a few days in June, 1742, and then under cir- 
cumstances of great distress and anxiety for himself, is simply idle, for no study of that life was ever made by "its discoverer," or could be.

* * * An exact count of the full birth rate of pups in 1912 showed an average family of 60 cows to each bull, with idle bulls to spare (p. 2).

'The official proof is in evidence of the fact that an "exact count" of the "full birth rate of pups in 1912" was never made, since all the attempts to make such a "count" in the seasons of 1901, 1902, 1903, 1904, 1905, and 1906 by trained, trusted agents were and are all self-confessed failures, and are so recorded. (See Exhibit G, postea.)

* * * Female seals are protected by law and custom from killing, and the breeding seals are in no way disturbed. A definite breeding reserve of the young males is marked and set aside from the animals first arriving in the spring before commercial killing is begun. The 3-year-old males and the larger 2-year-olds are killed, the younger and older animals found on the hauling grounds are released and returned to the sea, the former to be the basis of the future quota, the latter to replenish the stock of breeding males (p. 2).

That this "breeding reserve" has not been made and that yearlings (not "larger 2 and 3 year old males") have been killed by thousands and tens of thousands since 1890, up to date of 1913, is absolutely proven in Exhibits A, B, E, and F, and self-confessed therein (antea postea).

* *

*

*

*

*

The processes of land sealing do not contravene that natural law which decrees that the fittest shall survive. The struggle for existence in the case of the seal occurs at sea, where it gets all its food and where it spends the winter. The harsh conditions of the northern winter constitute a sifting process by which the old, the weak, and the inefficient are ruthlessly weeded out. Each animal returning to the islands in the spring is physically and vitally the best of its kind (p. 2).

The "harsh conditions of the northern winter" are never met by the seals; they leave the Bering Sea and the North Pacific annually, long before any ice appears there; they are in the same water as for temperature and weather during December, January, February, and March as they were in during June, July, August, and September prior annually; they are off San Francisco, Cal., in December, of Washington in March, and then go back to Behring Sea by Jume and July. There is no "struggle for existence at sea," such as Jordan asserts. It is fiction, not "truth," which he publishes.

Man's selection for his own uses is not of the best, but of a given age or size, among animals otherwise alike equally fit ( $p, 2)$.

The lessees have taken every young male seal from 2 years old up to 4 years annually that they could find on the islands since 1S96. If that is not getting all of the "best," then nonsense is sense, and Jordan is right. (See proof of this in Exhibits A and B antea and postea, where the full detail is given.)

At the time of the transfer to the United States the herd numbered about 2,500,000 animals. In 1896-1897 it numbered about 400,000 animals. It numbers in the sea. son of 1912 about 215,000 animals (p. 3).

The fact that Jordan has not the slightest warrant for saying that this herd only numbered in 1867 "about 2,500,000 animals" and in 1896-97 only "400,000 animals" is set forth in detail by Exhibit A anter. The nonsense and bald assumption of his census of 1896-97 
is clearly shown up there by the fact that 190,555 seals were found alive in 1913 , when, during all that period between-16 years-it has suffered an annual average loss of 80,000 seals, there must have been at least $1,000,000$ seals alive in 1896-97.

The cause of the decline of the herd is found in the development of a rival form of sealing, now known as pelagic sealing, taking advantage of the migration journeys and distant feeding habits of the seals (p. 3).

The chief "cause of the decline" is due to the illegal and injurious killing of all the young male seals that the lessees could secure annually from 1883 to 1913 , inclusive, and continued during 1910 , to its merciful prohibition, August 24, 1912. (See Exhibits $A$ antea and B postea.)

The evil effects of pelagic sealing were early recognized and efforts made to stay the development of the industry. The United States sought through arbitration with Great Britain to establish jurisdictional rights in Bering Sea for the protection of the herd, and, failing in this, by joint regulations formulated by the Paris Tribunal of Arbitration in 1893 attempted to restrict and limit the pelagic hunting. The regnlations failed of their object because of the long period of gestation and the distant feeding and migration journeys of the animals. A joint commission of inquiry, including British as well as American scientists, after two seasons of thorough investigation, reached the agreement that the herd's decline was due solely to the killing of females involved in pelagic sealing and foreshadowed the abolition of pelagic sealing as the only remedy. Incidentally, this commission exonerated the operations of land sealing, which had been accused in 1890 of being concerned in the herd's misfortune, from responsibility for it (p. 4).

That "joint commission of inquiry, including British as well as American scientists," did not "reach the agreement that the herd's decline was due solely to the killing of females involved in pelagic sealing," and it did not even hint at an "agreement" which foreshadowed the abolition of pelagic sealing. This is a falsehood, and utterly inexcusable in its relation here, with its bald, self-confession as such, in that "joint agreement" signed up by Jordan with his British associates in the Department of State, November 16, 1897.

After long-continued effort. on July 7, 1911, the United States obtained the cooperation of Great Britain, Russia, and Japan in a treaty abolishing pelagic sealing for 15 years. In this treaty the United States and Russia, as owners of the principal fur-seal herds. agreed to pay to Great Britain and Japan 35 per cent each of the product of their land sealing operations. This treaty went into effect with the season of 1912 , and as a result of its beneficent action it is estimated that 35,000 breeding female fur seak reached the ronkeries of the Pribilof Islands and brought forth their young in security, which would, under the operation of pelagic sealing. have failed to reach the islands or would have been killed on later feeding excursions. This fact in itself demonstrates the canse of the herd's derline and its caparity to restore itself if protected from further loss (p. 4).

This is the Hay-Elliott treaty of mutual concession and joint control with Great Britain, which Henry W. Elliott drew up in 1904-1905, and which John Hay approved in March, 1905, and which his sickne is and death in July following prevented the ratification of in June, 1905, at Ottawa; the lessees then came into power at the State Department after Hay's death; and, with the help of Dr. Jordan and his "scientists," prevented any action on it, until it was forced out of the State Department by the Senate Committee on Conservation of National Resources, February 4, 1911, and into the Senate, February S, 1911, and then ratified there, February 15, 1911 ; its terms being kept secret until Japan and Russia united in them, July $7,1911$. 
The essential consideration in the treaty is that the United States shall turn over 15 per cent of its land catch to Great Britain and a like percentage to Japan. The original attempt to fix the period of suspension at the full life of the treaty was in effect a repudiation of the treaty, and if carried through would undoubtedly have led to its abrogation. With the treaty ont of the way. pelagic sealing would naturally be resumed. The Senate compromise at 10 years was little better. The final period still violates the spirit of the treaty. because the United states can not justify the suspension, even for this period, as necessary to any interest of the herd (p.5).

Th's idea of "a repudiation of the treaty" when that "close time" of 10 years was adopted by the Senate, is simply an unfounded and fairly stupid one, when it is known that this treaty when first ratified between Great Britain and the United States, carried a memorandum attached to it, which ordered a "close time" of 10 to 12 yoar's from date of its ratification. Great Britain in 1905, and again in 1908, and again in 1911, was willing to have a close tinie for 10 years. Why? Because it was a wise and, sell-evidently, a good measure to adopt.

In addition to the contingent danger arising from possible dissatisfaction and abrogation of the treaty, the suspension has a direct and vital relation to the herd. The removal of the surplus males of a herd of polygamous animals is not merely possible. but in the case of the fur seals it contributes to their well-being. The fur seal is intensely gregarions. The females are crowded together at the critical period of the birth of the pups in groups, or harems, each in charee of a pugnacious and dominating male. This male is an animal of 500 pounds weight. while the female is an animal of 80 pounds, and the young at birth a weak thing of 12 pounds. The bull, in the ordinary round of harem discipline, is constantly rushing about and among his cows. while in warding off the attacks of the surrounding idle bulls he is rough and reckless in the extreme. The rookeries were in the season of 1912 at a minimum condition as to crowding and fighting, and yet they suffered a considerable loss of mups suffocated at the moment of birth through the overlying of the mother, some neighbor cow, or the trampling of the bull. This cause of loss was in 1912 about 2 per cent of all born. It is heyond the power of man to eliminate this canse of loss. He can minimize it by keeping down the stock of fighting bulls. To canse an increase of fighting or other source of disturbance upon the rookeries will make this loss mount up in geometric ratio (p. 5).

This absurd, untruthful, and utterly unfounded description of loss and injury to the herd by fighting bulls is fully laid bare and exposed as such in Exhibits A, antea, and G, postea. It has been the faked story which Dr. Jordan first attempted to use during 1910 (in conjunction with this man (lark) as a shield for the injurious and illegal close killing of all the young males by the lessees since 1896 . "They ought to be killed, all they could find," because "they would only grow up and fight," "tear the cows to pieces," and "trample their helpless young to death." Here is his faked story:

Dr. Evermann (reading):

"Dr. David Starr Jordan, president of Stantord Lniversity, chairman of the furseal commissions of 1896 and 1897 , and who, in company with his associates, spent the seasons of those two years on our seal islands and on the Russian islands, visiting every rookery and every hauling ground and studying the fur seal from every important point of view. Besides spending several months actually on the islands, he spent many more months in collating and studying the data resulting from his own observations and those of his associates and in al suly" of the literature of the subject."

6 . If the surplus males are not killed, they not only become valueless for their skins, but they grow up into bulls not needed for hreediug purposes, but which nevertheless pass on to the rookeries, where they do great damage to the breeding herd by fighting among themselves for possession of the cows, oiten tearing the cows to pieces, so injuring them that many of their pups are stilltorn, trampling the helpless pups to death, exhausting their own vitality and virility, and rendering themselves less potent than they would be without such useless struggle in short. causing infinite trouble and injury to the rookeries without a single compensating adrantage. 
Mr. Mccitine. Does that involve the conclusion of anyone else? Are those conclusions of your own based-.

Dr. Everuann (interposing). No; those are the conclusions of these twenty-odd people, whose names I have read. Now, on the other side, against those 22, we will place Mr. Elliott and Mr. Elliott alone. [Hearing No. 10, pp. 519, 521, A pr. 20, 1913, House Committee on Expenditures in the Department
of Commerce and Labor.]

In 1913, therefore, at least 6,000 superfluous males must be left to grow up as bulls. This must go on for five years. and in the end there will be in the years immediately following 1917 a total of 30,000 adult bulls. In 1912 no more than 1,500 bulls were needed by the herd. It can by no possibility use more than 3,000 bulls in 1917 and not over 4,000 in 1920. In the period following 1917 there will be 9 idle bulls for 1 in service. The inevitable damage to the rookeries which this condition of fighting will entail can be but faintly realized even by those who in 1896-97 witnessed a somewhat similar state of the rookeries due to a shorter period of suspension, 1891-1893. In 1896-97 there were an adult idle bull and two young bulls for each active bull. The conditions which we are to face in 1917 and thereafter is a condition where the ratio will be 9 to 1 instead of 3 to 1 . These idle bulls once saved must live out their natural life (p. 6).

The nonsense and untruth of the abore, the positive untruth and abject nonsense of it, can be fully appreciated by reading the facts set forth in Exhibit A antea; concluding pages.

Each one of the 30,000 useless bulls will have earried, as a 3 -year-old, a skin worth sto to the Government. These skins will be lost - a sheer waste of $\$ 1,200,000$. And this is a minimum figure, as the proluct of the hauling grounds will increase steadily. lurthermore, the cutting off of the regular supjly of sealskins for five years will affect the market. Sealskins will be superseded by other furs. and when the Government is rearly to seek an outlet in its increased quotas of 1918 and 1919, the market will be found shugish and the prices low p. (j).

This is the argument of Simple Simon, who killed the goose which laid the golden egg. See Exhibit $\Lambda$, antea, for illustration of it fully, in concluding pages.

This remarkable circular of untruth fitly ends with the following "foxy" statement:

The amendment suspending land killing has provided for the human residents of the Pribilof Islands, by allowing a linited amount of killing for fresh meat for natives' food. There is, however. other animal life on the islands which, through a century of habit, las come to lepend upon the products of the killing field for an important part of $\mathrm{its}$ stistenance. Nost important among these animals is the Aretic blue fox. The fox herl is small, but is animal to animal. as valuable as is the fur seal. In the 40 vears of our control 40,000 pelt $s$ of hlue foxes have been taken. The herd is capable of indefinite expansion through increase of fool supply. In summer, when the birds are present, the fores are tairly well proviled for. but in winter their chief dependence is in the rarcasses of the seals left on the killing fields. They were beginning to starve and eat one another on the Pribilof Islands at the time the junior author left there this fall. The killing fields were absolutely bare. It is certain that the blue-fox herd will be clecimated before spring, and if the suspension of land killing is continued for the full five years, unless artificial feecling is substituted - a thing difficult of accomplishment the blue-fox herd will be wiperl out or at least reduced to a point so low that its restoration will be a matter of years.

The bircls, of which there are thousands upon thousands on the islands, are not eronomically useful to man, but it mav be added that they, too, are affected by this umnecessary, harmful, and wasteinl suspension of land killing (pp. 6,7 ).

The best answers which we can make to this idle and fairly puerile demand for seal slaughter that the fox herd is dependent on seal killing for its existence is the following official entry made by Ezra W. Clark, United States special agent, who has been busy on St. George Island for nearly 10 years, studying the fox question in that time from every angle. 
Maj. E. W. Clark makes this official entry in the St. Paul log or journal after long experience with the foxes of St. George:

Tuesday, December $17,1901$.

The season of trapping was a little under two weeks, taking off Sundays and the holiday. All the men came into the village for one or two days during the trapping. The fox herd on this island seems to have increased slightly rather than diminisher during the last two or three years. I learn that the seal meat saved and put out last year as food for the foxes was scarcely tasted by them. Evidently they did not suffer for the want of food. Year before last I understand that no seal meat was offered them, but the last year and this year there was trapping, and this year the animals seemed a trifle more abundant than last. I am by no means satisfied that an artificial supply of food is necessary on this island for the maintenance of the herd, or even for its increase (p. 160).

With the sending out of this improper circular, as above described, the old influences got busy and actually persuaded President Taft to send a message on January 8, 1913, to Congress (S. Doc. No. $997,62 \mathrm{~d}$ Cong., 3d sess.) in which he urged Congress to repeal the close-time law of August 24, 1912, and does so on this improper and untruthful statement of Dr. Jordan in the premises.

No attention was paid to the request of Mr. Taft, and he was very promptly informed by leading Senators that they would not change the law.

This did not prevent that discredited scientist from making another visit to the Senators and Members by sending them the following letter (with an inclosure of a reprint of his "economic circular" above cited, in the Nation), to wit:

\section{Office of the President, \\ LeLand StanFord Junior University, Stanford University, Cal., March 31, 1913.}

On January 25 the writers called to your attention the need of repeal in the matter of certain fur-seal legislation of August 24, 1912. The Sixty-second Congress, in its third session, took no steps in the matter. On the other hand, it cut from the sundry civil bill the appropriation for the maintenance of the force of Government agents on the fur-seal islands, reducing this force to a single caretaker on each island. The bill failed because of the veto of the President and must come up again in the special session. As the act suspending land sealing was a blow aimed directly at the integrity of the treaty of July 7,1911 , suspending pelagic sealing, so the recent act is a blow aimed at the defense of the herd on its breeding grounds, inviting the raiding of the the islands. We have put the bearing of both these measures clearly in a letter that is being mailed to each Member of the Sixty-third Congress. A copy of this letter is inclosed. Will you not take up this matter anew and urge upon Congressmen, perhaps the President himself, the need of rational action in the interests of the fur seals?

DAVID STARR JORDAN.

George Archibald Clark.

Soon after this letter was generally receired (Apr. 10, 1913) the Secretary of Commerce put a quietus on the subject by directing the Bureau of Fisheries to dismiss the ideas advanced by Dr. Jordan and carry out the law to the letter. 


\section{PART 2.}

TThe census of the Alaskan seal herd on the Pribilof Islands as taken July 10-20, 1913, by United States Special Agents Henry W. Elliott and A. F. Gallagher, under authority and by instruction of the House Committee on Expenditures in the Department of Commerce.]

\section{CENSUS OF KETAVIE AND LUKANNON ROOKERIES.}

[Field notes to accompany cbart and survey of condition of Ketavie and Lukannon rookeries, St. Paul Island, Pribilof group, Friday, July 11, 1913, by Henry W. Elliott and A. F. Gallagher, special agents of the Housc Committee on Expenditures in the Departiment of Commerce.]

(The condition of this rookery when comparison is made with that of 1890 is founded upon the published official survey made by Henry IV. Elliott and Charles J. Goff, July 10, 1S90, and duly published as H. Doc. No. 175, 54 th Cong., 1st sess., pp. 31, 32, 33.)

We have taken up this morning, the survey of the Ketavie rookery, beginning at station $\mathrm{C}$ of the 1890 survey.

We find at station $\mathrm{C}$ and station $\mathrm{B}$ a complete climination of every soal reported thereon in 1590 . The rookery ground then occupied in 1890 as well as that of 1874 is now all overgrown with thick sod, flowers, mosses, grasses, and lichens, which cover all the rocks-a complete elimination of all of that 1890 fur saal life within limits of stations $A$ and $B$. Then, from stations $B$ to $C 2$ southeast, reaching to the extreme point, we find nothing but one solitary 6-year-old bull and a single cow, in a rocky pocket of the surf wash, together with one cow swimming in the water nearby.

As we proceed to station D of the survey of 1890 we find that the entire sum of seal life in existence between is confined to a series of pocket harems along the rookery margin just above the surf wash. Thes? harems agroregate $S$ bulls and about 325 cows.

At the extreme foot of station D, looking out to sea, on a surfwashed shelf, we see the first "porl" of holluschickie on this rookery-some 50 or 60 small male and yearling seals all told.

From station D to station E, or the southern foot of the amphitheater of 1890 , the seal life has been quite eliminated, and is confined to a series of pocket harems, consisting of 20 bulls and about 700 cows. ${ }^{1}$

We now take up the amphitheater at the base of Lukannon Hill. That small yet beautiful and impressive concentrated view of animal life, which in 1874 invariably caused the most casual observer to exclaim, "What a sight!" is totally deserted, with the exception of three harems, with about 65 cows at the foot and right north of station $\mathrm{E}$; a thick growtl of grass and flowers is now on the ground where nothing but seals once laid, and reaching right to the water's edge.

On the extreme northern surf-washed point of this amphitheater, or station $\mathrm{F}$ of the 1890 survey, we observe a pod of about 50 holluschickie, being the second batch which we have seen this morning. From this point to station $G$ of the 1890 survey, embracing the entire sweep of the Lukannon rookery, we find the life of 1890 con-

\footnotetext{
1 Touching this relation of the cows to the bulls in 1890 , here, as contrasted with 1874 , the following is pertinent (p. 37, H. Doc. No. 175, 54 th Cong., 1st sess.), to wit: "On Lukannon this last summer, while there were two-fifths as many cows as in 1872 , yet tlie bulls did not arerage more than one-fifteentli of the number they slowed in 1872. On Keetand it was no better; il anything a shade worse, no young bulls anywhere offering service or attempting to land. This undue proportion of the sexes, and the general apathy of the breeding bulls, is characteristic ol all these rookeries to-day. **** In 1872-1874 it was just the opposite."
} 
fined to a series of bunched harems, immediately under Lukannon Hill, which, by a careful estimate, shows from 35 to 40 bulls and some 2,200 to 2,500 females. We notice an entire absence of the "polsecatchie," and we see but three or four 6-year-old bulls on the outskirts, and none in the water. The sweep from the foot of Luckannon Hill to the westward, upon which the great bulk of this rookery existed in 1874, and again in 1890, is completely deserted, not a single harem being in existence there at the present time. The entire field of 1874 , under our feet here on the slopes of Lukannon Hill, which was polished bare of every vestige of regetation, and the rocks also, of all lichens, is now carpeted with a thick sod between the rocks, and the yellow, brown, and gray rock lichens that have grown since; also the lines of 1890 are nearly as well covered with this vegetation, and unite in giving eloquent proof of a complete elimination of the seal life thereon. ${ }^{1}$

We have looked into every harem to-day on these two rookeries; we have not observed any evidence of fighting between the bulls, even where they are close and within reaching distance of each other; nor has there been any attempt of the outside bulls to enter the harems and engage in combat, although a few bulls--bulls without cows-are lying close on the outskirts of the harems. The same understanding exists to-day between these breeding bulls as it did in 1S74, to wit, that having fought for their stations and having occupied them between the 4th of May and the middle of June, by common consent and universal agreement they stay right there, undisturbed by one another thereafter during the breeding season. The proof of it is under our eyes at every harem that we have inspected and its neighbor.

This remarkably striking elimination of that life of 1890 , to say nothing of the astounding shrinkage from 1874, is one of the most impressive sad exhibitions that the investigator finds on these islands. The mighty roar and the rumble on these rookeries of that early time are now succeeded by a low and indistinct murmur and intermittent gurgling, gutteral growls.

During this survey, looking down into those harems in the pockets of Ketavie, in the amphitheater, and under the brow of Lukanin Hill, where these notes are now being made, we have been unable to see the slightest evidence of a dead or a trampled pup or of a cow or cows torn or killed. These harems being directly under our eyes, we have a clear view of the pups, looking up and along the sweep occupied by them. Many pups are newly born, evidently only a few hours or minutes, as the placentas or afterbirths lay bloody and fresh

1 The following official record was made of this seal life on Lukanin and Ketavie in July, 1874 (see Monograph Seal Islands: Elliott):

"The next rookeries in order can be found at Lukanin and Ketavie. Here is a joint blending of two large breeding grounds, their continuity broken by a short reach of sea wall right under and at the eastern foot of Lukanin Hill. The appearance of these rookeries is like all the rest of them, peculiar to themselves. There is a rounded swelling hill at the foot of Lukanin Bay, which rises pcrhaps 160 or 170 feet from the sea, abruptly at the pount, but swelling up gently from the sand dunes in Lukanin Bay to its summit at the east and south. The great rookery rests upon its northern slope. Here is a beautiful adaptation of the finest drainage, with a profusion of those rocky nodules seattered everywhere over it, upon which the female seals so delight in resting.

"As we stand on the bald summit of Lukanin Hill we can turn to the south and look over to Ketavie Point, where another large aggregate of breeding seals comes under our eyes. The hill falls away into a series of faintly terraced tables, which drop down to a flat. That again abruptly descends to the sea at Ketavie Point.

"Between us and the Ketavie rookery is the parade ground of Lukanin, a sight almost as grand as is that on the reef, which we have feebly attempted to portray. The sand dunes to the north and west are covered with the most luxurious grass, abruptly emarginated by the sharp abrasion of the hauling seals." 
before our eyes; but if a pup has perished from trampling, or if a cow has been killed by the fighting of bulls, we are unable to see it. It certainly is not in evidence to-day, and it never was in evidence in 1874 or 1890 . The habits of these animals certainly have not been changed.

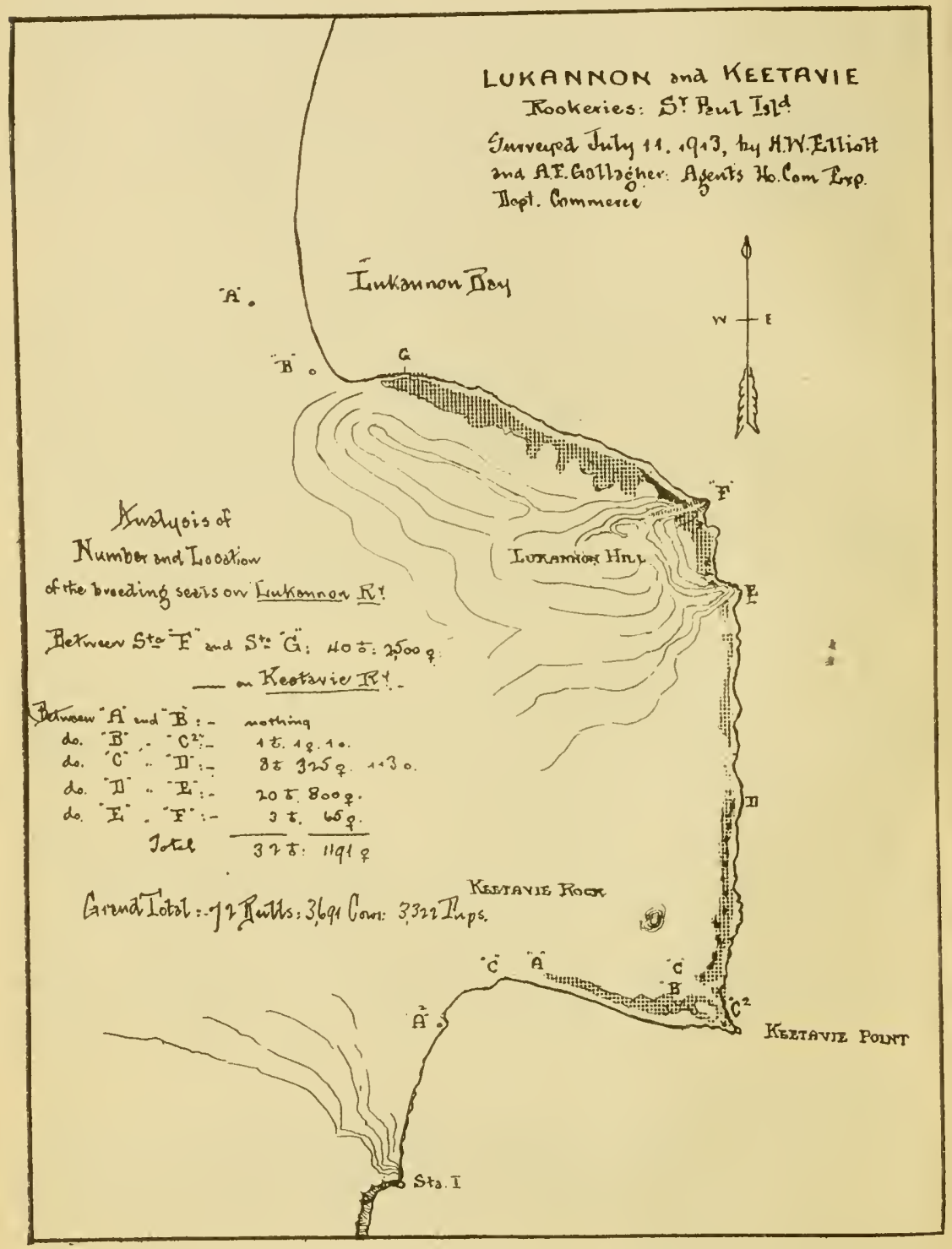

Review from the summit of Retavie rock.-The entire field occupied by breeding seals on this rookery in 1874, and with the exception of a small fringe of pocket harems which we have noted on the surf margin of the rookery-this entire field of 1890 is abandoned by seals. 
The ground of 1874 is now fairly covered with a coarse, thick sud, and that of 1890 with a finer grass, rapidly passing into the sod aforesaid, while the once seal-polished rocks are now yollow and brown with lichens. This picturesque and fine breeding ground is practically desolated. There are no holluschickie in sight, either hauled out for' shelter in the pockets of these harems or anywhere visible on the rookery margin. There are no polsecatchie in the water and no ille bulls in the rear of these harems. ${ }^{1}$ The seals that are existing look well. The bulls all appear' to range between 7 and 8 years to 15 years. There is no very old or superanuated bull thus far observed.

To recapitulate: For Lukannon and Ketarie rookeries, July 11 , 1913, we find on Lukannon 40 bulls, 2,500 cows, 2,300 pups; Ketavie, 32 bulls, 1,191 cows, 1,000 pups; season of 1990, on Lukannon, 900 bulls, 36,000 cows, 33,250 pups; season of 1S74, on Lukannon, 4,880 bulls, 85,000 cows, 78,000 pups; season of 1890 , on Ketavie, 340 bulls, 13,500 cows, 12.500 pups; season of 1574, on Ketavie, 4,730 bulls, 80,000 cows, 72,500 pups.

\section{CENSUS OF LOWER AND TPPLIR ZAPADNIE ROOKERIES.}

[Field notes to accompany the chart and survey of condition of lower Zapadni reokery, St. Paul Island, Pribilof group, Saturday, July 12, 1913, by Henry W. Elliott and A. F. Gallagher, special agents IIousé Committee on Expenditures of the Department of Commerce.]

* "Th condition of tha rookery wh 'n comparison is made with that of 1890 is founded upon th' published official survey made by IIenry W. Elliott and Chorles J. Goff, July 10, 1890, and duly published as H. Doc. No. 175,54 th Con., 1st sess., p. 31, 32, 33.)

We begin this morning at station $\mathrm{C}$ of the 1890 survey, and from there, as we go to station $\mathrm{O}$, no sign of saal life is apparent. From station $O$, as we proceed down, every vestige of the herd has disappeared from this ground to the bight and clear back to station A of th. 1890 survey. Jag A his completely disappeared; not even a fringe or suggestion of it at the sa margin in the bight. The grass and flowers actually cover every foot of this area of the 1874 and 1890 surveys righte down to th surf-beaten margins of the bight. Under foot hre is tha haviest sod that we have thus far trodden upon in this whole area of abandoned saal territory on the island rookeries, showing that th entire disappearince of the herd from this ground must hrve taken place at least 10 years ago, save solitary or scattred saals which might heve been in existence then.

We now pass over to jag B of the 1890 survey, and we find about 12 bulls and 125 cows, with no idle bulls around and no "polsecatchie" in sight. This area of 1890 is completely desolated, save that thin fringe of cows and bulls on th surf margin.

1 The loss of life here in 1890 , as contrasted with its form in $157 t$, is deseribed officially as follows (p. 36, H. Doc. 175,54 th Cong., 1 st sess.) to wit:

"The unusually heary loss sustained by Ketavie rookery and the other absence of the hollusehickie, or killable young male seals, where they trooped in platoons of tens of thousauds in 1972-1\$74 upon the Lukannon parade ground made the view from Lukannon 1Iill an exceedingly sad one at auy time last summer Grass is now growing thickly down to the rery water's edge over the parade grounds here of 1872-1874, and creeping into the rookery grounds also. This grass, which grows up over the abandoned seal parade, is quite different in fiber and color from that which has never been disturbed or destroyed by the hauling seals. It is quickly noted and marked as "seal grass," since it grows closer and thicker and softer than all surrounding grasscs. There is no contradietion possible of its silent though eloquent testimony of the hour - of that absence of thosc swarming herds which so impressed me in $1572-1874$ as they restlessly swept hour-of that absence of thosc swarming herds which so impressed me in

* Glyceria angustata. - It is conspicuous as a band of yellow cmarginating that green ground of the indigenous growth of grasses and flora where the seals have never been for a long, long time. 
Passing from jag $\mathrm{B}$, we now proceed southward to jag $\mathrm{C}$ of the 1890 survey. We find here that the seal life has entirely disappeared, save at the foot of jag $\mathrm{C}$, where we observe carefully about 1,500 cows and count 50 bulls. In between jag $B$ and jag $C$ of the 1890 survey we find some 1,500 holluschickie, chiefly yearlings, with 2-year-olds and a few 3-year-olds.

We now proceed from this location across to jag $D$ of the 1890 survey. Here we find the entire breeding area of 1890 is completely abandoned, and, as we go to jag E, that area also is abandoned, save a fringe of 7 or 8 ragged harems, with 15 or 20 bulls and about 300 cows.

From thence we proceed around to jag $\mathrm{F}$, and at the foot of that seal-breerling record of 1890 is a massing of some 1,250 to 1,500 cows and about 45 or 50 bulls. Between these breeding seals of $\mathrm{E}$ and $\mathrm{F}$ were hauled out about 1,200 or 1,400 holluschickie. This entire area between $\mathrm{F}$ and $\mathrm{E}$, which was occupied in 1890 by breeding seals, has been completely abandoned by them, with the exeeptions above noted. Grass, flowers, and lichens eover all this ground and the roeks right down to the water's edge.

From jag F we now proceed to jag $G$ and jag H, at Zapadni Point, and we find that the life of 1890 has faded out to about 2,000 cows and about 60 bulls, all being right at the surf margin, as usual; and running out to the point and under the drop we find seven or eight ragged harems, or in all it makes an aggregate grouping of about 2,000 cows and 60 bulls, which we consider a very liberal estimate of this life that survives between jag $G$ and the Point. A single polseeatch, the first seen to-day in the rear, was noticed by us. Three or four 6-year-old bulls constitute the entire surplus bull life at this point of the finish of our survey of Lower Zapadni.

Recapitulation.-As we finish this survey of the breeding life on Zapadni in contrast with its condition of 1890 , and before we close these notes, with the chart of 1874 under our eyes, we are impressed with the fact that the herd of 1874 , in its dwindling to its eondition of 1890 , was decimated fully two-thirds; but the decrease since 1890 to the present hour shows a loss of nearly nine-tenths of the figures of 1890 . Great as that loss was in 1890 , from the figures of 1874 , it is impossible not to be impressed with the still greater decline up to date.

During this survey, and indeed, for that matter, since we began this work, we have taken notice of the Coast and Geodetic Survey's series of painted rocks as they stand here to-day, which those engineers marked and numbered in 1897 to declare the outer limits of that hauling of breeding seals during that season; we have noted that they closely follow the lines of Elliott's 1890 survey. These white-numbered records made of seal hauling on the roeks in 1897 show that even then the high-water points touched by the seals in 1890 were not much receded from. It would seem from the record of this Coast Survey's making that the diminution since 1897 was far more marked than that which took place between 1890 and 1874 ; it is unnecessary to say that the immense shrinkage from 1890 to date is emphatically and indisputably confirmed by this painted-rock record of the Coast and Geodetie Survey. The hauling grounds of Zapadni where the holluschickie swarmed in 1874 on this magnifieent plateau were not, 
$+-$ 


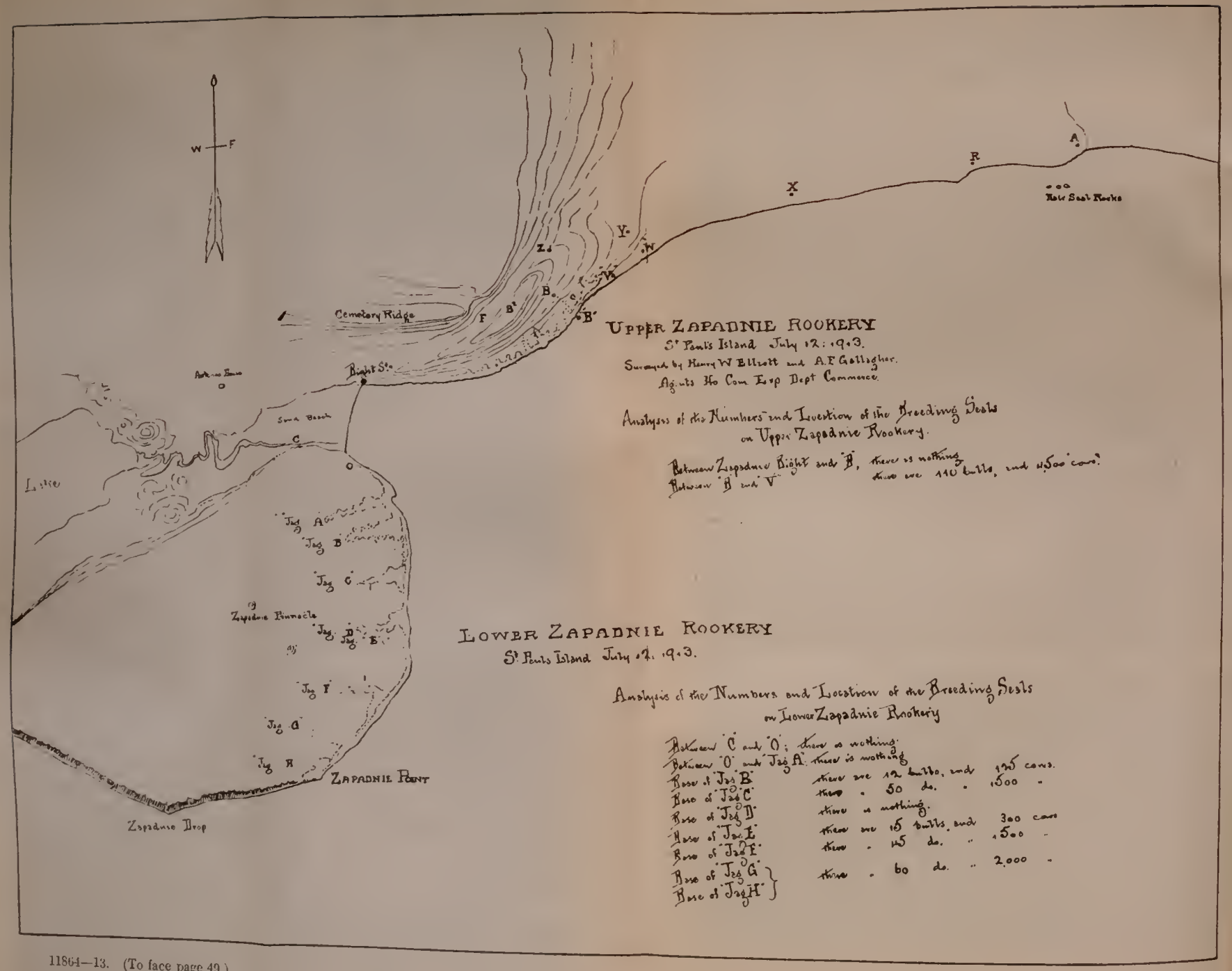

1186-1-13. (To face page 49.) 
of course, entirely abandoned in 1890, but the small hauling of nonbreeding seals in 1890 has dwindled away this year to even a fainter record of less than 2,500 holluschickie assembled, and that, too, after being undisturber since the beginning of the senson (being the first time not driven in the last 33 years), for we are creditably informed that no driving and no visit to this rookery has been made this year by the natives or agents in charge prior to our survey to-day.
Upper Zapadni.-We now take up the lines of Upper Zapadni.

Beginning with the inital point of the surver of 1890 , at the intersection of the sands of Zapadni beach, we find the whole of that breading life eliminated between this station up to the foot of station B. Then we find a series of continuous ragged harems at the surf margin ending at station $V$, which gives us a total of about 4,500 cows and about 110 bulls and about 40 vagrant and spent bulls, all hauled just north of station $T$, with a few holluschickie. In this entire circuit, as we traverse it foot by foot, we have seen no sign of the polsecatchie. Wre have seen three or four 6-year-old bulls only. 'This stretch from Zapadni Bight to station $V$ is perhaps as vivid an illustration of complete extinction of the breeding lines of 1874 as can be found on the rookeries of the island. Indeed, it is a most melancholy exhibit as we pass over it to-day. We have seen no holluschickie, except four or five, with those old whipped or vagrant bulls, hauled out just beyond station $Y$, as above noted. ${ }^{1}$

To recapitulate.-F or Lower Zapadni rookery, July 12, 1913, we find 1S2 bulls, 5,425 cows, 4,S50 pups; for Upper Zapadni rookery, July 12, 1913, we find 110 bulls, 4,500 cows, 4,100 pups.

On both Zapadnis season of 1890 there were 1,600 bulls, 60,000 cows, 54,000 pups; season of 1874 there were 12,514 bulls, 220,000 cows, 198,000 pups.

\section{CENSUS OF TOLSTOI ROOKERY.}

[Field notes to aecompany the chart and survey of eondition of Tolstoi rookery, St. Paul's Island, Pribilof gromp, begun Saturdav, July 12, 1913,2 p'elock p. m., by Henry W. Elliott and A. F.. Gallagher, speeial agents House Committee on Expenditures in the Department of Commerce.]

(The condition of the rookery, when comparison is made with that of 1590 , is founded upon the published official survey made by Henry W. Elliott and Charles J. Goff, July 10, 1890, and duly published as House Document 175, Fifty-fourth Congress, first session, pages $31,32,33$.

From station A to station $\mathrm{E}$, of the 1890 survey, all seal life has been completely eliminated. At the base of station $\mathrm{E}$ is a small

1 The contrast of that fine condition of Zapadni in 1872-18it with what it was found to be in cluring 1890 is made as follows (H. Doe. No. 175,54 th Cong., Ist sess., p. 40 ), to wit:

"It is impossible to convey that fill sense of utter desolation which the vacant seal area of 1872 on this fine rookery aroused in my mind last July (1S90) while then making my survey of it. Grass and flowers springing up over those broad areas of the once occupied hanling grounds here, where in $1872-18$ it thousands upon thousands of young male seals hanled out and over throughout the entire season, and were undisturbed by any man, not even visited then by anyone, except myself. No one then ever thought of such a thing as coming over from the village to make a killing at Zapadni, there being more seals than wanted close by at Tolstoi, Lukannon, and Zoltoi Sands. This not alone, hut that splendid once clean-sivept expanse of hauling grounds in English Bay between the Zapadnis and Tolstoi is all grass grown to-day (except over its areas of drifting sands) with mosses, liehens, and flowers interspersed. It is entirely barren of seals, save a lonely pod under Middle Hill.

"Lower Zapadni is certainly the roughest surfaced breeding ground peculiar to the seal islands, and it is a curious place on which to riew the seals as they locate themselves, for as yon walk along they suddenly appear and disappear as they haul and lay in those queer lit tle valleys and canyons here whicli havo been formed by lava bubbles of the geological time of the eleration of St. Paul Island from the sea. But to-day so seant is the massing of the breeding seals here that that unbroken mighty uproar which boomed out from them in 1872 is wholly absent. It is positively quiet, save the subdied sheep-like calling of the females and the lamb-like answer of their ofispring." 
batch or mass of harems which will total about 1,500 cows and about 40 bulls; and, lying on the hill slope this side of them, there are about 800 to 900 holluschickie, all down in, under, and lying on the old breeding ground of 1874 , which is totally abandoned. ${ }^{-}$

We now proceed from station $\mathrm{E}$ to stations $\mathrm{F}$ and $\mathrm{G}$. No polsecatchie and no idle bulls on this ground are seen. Right at the base of jags $\mathrm{F}$ and $\mathrm{G}$ of the 1890 survey is an aggregate of seven harems with not to exceed 200 females. There are about 20 vagrant bulls bunchad in with the holluschickie that we have just enumerated.

At the foot of station B, and over to station $\mathrm{C}$ of the 1890 survey, we find a series of hirems right at the surf margin which will carry about 3,500 cows and about 60 bulls. That completes the sum total, area, and location of the hill-side rookery life of to-day as compared with th? survey of 1890 . Here we have seen a pod of 25 or 30 vagrant bulls clos aly lying in with th ? hollusehickie which we have mentioned, th. largest group of such spent male life that we have seen thus far. Thrre are no polsecatchie in th rear and no idle 6-yearold bulls. Th re is no evidence of fighting, and the sandy area immediately under station $B$, and reaching to station $B$, carries no sign of a dead pup, or sand worm mortrlity, although these seals are resting on that sind just as thay did in Dr. Jordin's time; and the stones which were placed there later by Mr. Judge are now wholly surrounded whore not hidden by the sand which he thought he had covered by planting those rocks. From station $\mathrm{C}$ of the 1890 survey is the same balt margin to-day under tho Tolstoi Bluff's that was existent there in 1890 . It has a fringe of harems irregularly sprawled just above the surf wash and carries, it is safe to say, at least 3,500 to 4,000 cows and about 50 bulls, with no idle bulls of any description in sight or any polsecatchie-not onc.

To recapitulate.-For Tolstoi rookery, July 12, 1913, we find 157 bulls, S,750 cows, 7,850 pups. Season of 1890 , there were 850 bulls, 31,200 cows, 28,000 pups; season of 1874 , there were 6,450 bulls, 115,000 cows, 105,000 pups.

The particular mamner and method followed by Elliott in getting these figures of seal population for those large rookeries of $1872-$ 1874 , and relatively large in 1890 , when contrasted with their form in 1913, is fully set forth br the details given in House Document To. 175, Fifty-fourth Congress, first session, pages 29-57 inclusive. The following illustration of his survey of Tolstoi in 1872 , and again

1. The Tolstoi hill slope of 1872 is described, in 1574, by Elliott (pp. 53-54,Monograph Seal Islands) as follows : "Directly to the west from Lukannon, up along and around the head of the lagoon is the seal path road over which the natives drive the holluschickie from Tolstoi. We follow this and take up our position on any one of the several lofty grass-grown sand dunes, close to and overlooking another rookery of great size. This is Tolstoi.

"We have here the greatest hill slope of breeding seals on either island, peculiarly massed on the abruptly sloping flanks of Tolstoi Ridge, as it falls to the sands of English Bay and ends suddenly in the precipitous termination of its own name, Tolstoi Point. Here the seals are in some places crowded up to the enormous depth of 500 measured feet from the sea margin of the rookery to its upper boundary and limitations: and, when viewed as I riewed it in July (1872), taking the lines and angles as shown on the accompanying sketch map, I considered it with the bluffs terminating it at the south, and its bold sweep which ends on the sands of English Bay, to be the most picturesque, though it is not the most impressive, rookery on the islandespecially so, when that parade ground, lying just back and over the point, and upon its table rock surface is reached by the climbing seals as they haul up from the sea below.

"If the observer will glance at the map he will see that this parade ground in question lies directly over and about 150 feet above the breeding seals immediately under it. * *

"From Tolstoi at this point, sweeping around 3 miles to Zapadine, is the broad sand reach of English Bay, upon which and back over its gently rising flats are the great hauling grounds of the holluschickie, which I have indicated on the general map and to which I have made reference. $* * *$ Looking at the myriads of bachelor seals spread out in their restless hundreds and hundreds of thousands upon this ground, one feels the utter impotency of verbal description, and reluctantly shuts his note and sketch books to gaze upon it with renewed fascination and perfect helplessness." 
in 1890 will suffice as to the details for all of the 17 breeding grounds on the Pribilof Islands, which were corered in the same manner, to wit, he says (Hearing No. 4, Committee on Expenditures in the Department of Commerce and Labor, July 11, 1911, pp. 186-187, 190-191, and 192):

But I had no idea as I began the work and completed it, insofar as the landed area went, of making a census of the seals upon the line of Capt. Bryaut's speculation, because I early saw that there were so many variations in the sizes of the seals, the irregular massing and unmassing of the harems, that the plan of locating just so many adult seals to a given area was impracticable.

But as I hung over these rookeries day after day I became impressed with the fact that no matter whether the mother seals were present on the ground, or absent ou their food excursions, their pups, or young ones, never left the immediate area of their birthplace on the rookery up to a time in the season not later than the 10th or 20 th of each July; that if I counted them in a given area during that period I should then know just how many cows belonged to it, and only by taking the pups as my guide could I get at the real number of females; the males were steadfastly on the ground all the time, and then a general estimate for the number of virgin females could be made upon the ratio of this pup count, as it was a basis of the birth rate of the entire herd.

While this subject grew upon me, I called the attention of my associates on the island (St. Paul, 1872-73) to it. One of these gentlemen, Mr. William Kapus, was an unusually well-educated man (the company's general mauager), and a man of affairs as well. He took deep interest in the solution of this seal-space problem as I presented it to him in the following form; also Dr. Kramer, the surgeon, another cultivated, scholarly man, aided me in the inquiry:

1. The seals haul out on these breeding grounds with great evenness of massing never crowded unduly here, or scattered there-so evenly that if suddenly every mother were to appear at the height of the season there would be just room enough for all, without suffocating or inconveniencing their lives on the rocks.

2 . That in estimating the number of seals in the breeding grounds we must make the number of pups present at the lieight of the season the unit of calculation, because their mothers are never all present at any one time, not half, and at many times not one-third of them are; that the height of the breeding season is between July 10 and 20 annually.

Upon these two fundamental propositions I stirred up a vigorous discussion and examination as to their truth or untruth among the white men then on the islands, or South Island especially, late in 1872, and until the close of the season of 1873 the settlement of this question was left open. Then each and every white man on the islands at that time (there were nine of them) subscribed heartily to the truth of these, my assumptions, as a true working hypothesis.

Just because I had traveled over these rookeries day in and day out, when seals were there and when absent, was why I recognized this law of distribution, and I will safely venture to say that I have taken two steps to Jordan's one in this work on the rookery grounds; with every fissure and embedded lava rock (these loose "bowlders weighing tons" on Kitovi and only few such "bowlders" on Gorbatch), I am familiar, and I found to my surprise, at first, that Kitovi was an ideal massing ground for the brecding seals, and Gorbatch also; that these jagged rocks, nearly all deeply imbedded in the detritus of the cinder and lava slopes, actually carried more seals than if they were perfect plane surfaces. Wherever I found a miniature lava butte on these breeding grounds (they are all of volcanic superstructure) that the seals could not scale or otherwise occupy, the area of the same was deducted from the sum of square feet belonging to the ground, and I never made the "blunder of assuming the same distribution everywhere," by taking this precaution, and in the following way: First, I carefully located the herds as they lay on the several breeding grounds during the height of the season, i. e., between July 10 and 20, which I discovered to be the time in 1872; this location was rapidly and accurately made on a land chart of the rookery ground prepared early in the season and before the seals had hauled out. By having these charts all ready, with the stations from which my base lines and angles were taken, all plainly in my view when the seals hauled out, it was a simple thing to place the bearings of the massed herds on the chart; the reef and Gorbatch grounds made a busy day's work, and no more for me, because thus prepared; the same of Zapadnie. Tolstoi easily finished in half a day; same of Lukannon, same of Kitovi, Polavina a short day's work, while Novastoshals, or the large Northeast Point breeding ground, took the best part of two days. The St. George rookeries were handled in even shorter time by this method. 
On page 38 of my 1890 report, which was in Jordan's hands when he first started for the seal islands, appears the following detailed explanation of each and every step taken by me in surveying each and every rookery as well as Tolstoi.

\section{Detailed analysis of the survey of Tolstoi rookery, July 10, 1890.}

[Sea margin beginning at $A$ and ending at $D$.

Square feet.

800 feet sea margin between $A$ and $B$, with 80 feet average depth, massed.. 64,000 400 feet sea margin between $B$ and C, with 60 feet average depth, massed.. $\quad 24,000$ 1,600 feet sea margin between $C$ and $\mathrm{D}$, with 10 feet arerage depth, massed.. 16,000 Jag E has 300 feet of depth, with 40 feet average width, massed......... 12,000 Jag F has 100 feet of depth, with 40 feet average width, massed.......... 4,000 Jag G has 120 feet of clepth, with 40 feet of average width, massed........ 4,800

Total square feet................................. 800

The annexed colored chart ${ }^{1}$ that this legend illustrates carries all these stations and base line points in detail. Every topographical feature is faithfully indicated on it, and these specialized lines of average depth were drawn over these sections of the herd as it lay upon the ground on that day and date-the proper time of the season.

Now, in orcler that this detailed analysis of Tolstoi can be summed up in one compact sensible expression I take the entire length of its sea margin, 2,800 feet, and divide the entire sum of its square feet of massed area, 124,800 feet, by it; that enables me to say, "July 11, 1890, Tolstoi has 2,800 feet of sea margin with $44 \frac{1}{2}$ feet of average depth-124,800 square feet of superficial area, making ground for 62,400 breeding seals and young.'

Here is the result in detail of my survey of Tolstoi in 1872, which was verified by myself and Capt. Washburn Haynard, U. S. N., in 1874:

\section{Detailed analysis of the survey of Tolstoi rookery, July 15, 1872.}

[Sea margin beginning at $\Lambda$ and ending at D.]

Square feet.

1,000 feet sea margin between $A$ and $B$, with 350 feet average depth, massed . 350,000 400 feet sea margin between $B$ and C , with 150 feet average depth, massed. . 60,000 1,600 feet sea margin between $C$ and D, with 30 feet average depth, massed.. 48,000

Three thousand feet sea margin on Tolstoi breeding ground, and 458,000 square feet in it, making ground. in round numbers, for 225,000 seals.

It will be noted that in this Tolstoi summary for $1872 \mathrm{I}$ ignore the real presence of 8,000 square feet, and deliberately reduce that estimate of seals from 229,500 to 225,000 , because I never ran the risk in my work of 1872 and 1890 of being a foot or two ahead of the real average. I carried this cantious reservation all throngh my surreys of each and every rookery, and this is the reason why Capt. Maynard, my associate in the work of 1874 , makes his estimate, based upon this survey, of the sum total of Pribilof seal life so much higher than mine. He declared that he was satisfied from close personal supervision of taking all our land angles in 1874 that $I$ was safely inside of the real limit of supervision and that the figures of the survey were conservative and right. He was then, as he is now, a skilled mathematician and hydrographer, and he had the right to his opinion based upon the figures of that careful work. Yet Jordan has the sublime impertinence in 1908 to sneer at this unbiased, careful survey of 1872-1874, by saying "the 150 feet is a guess, and that only." (Page 80, note.)

I used these figures of 1890 in detail for Tolstoi because I do not give the detailed analysis or figures of $1872-1874$ (only the summary) in my 1890 report of its sea margin and square feet, viz, " 3.000 feet of sea margin, making ground for 225,000 breeding seals and their young," not deeming it necessary to produce so many detailed figures when my charts for both seasons were in full evidence in the published work of 1890 .

I never made the blunder of attempting to count all the bulls, all the cows, or all the pups on any rookery in 1872-1874. The utter stupidity of such a step never entered my head. It never did in 1890 , even when the ragged remnant of the great life of 1872 was before me. It has only remained for Jordan and his job lot of assistants to race up and down these desolated breeding areas, in their idle attempts to do so, and the record of the self-contradiction of their own work bristles with the folly of it on a score of pages in his report. 
Here is what I published in 1872-1874 relative to the seal unit of space, and it is clear enough to men who have reasoned to the line with me on the ground itself; to men like Capt. Maynard, United States Navy, 1874, and William Kapus, general manager of the lessees in 1872-73, and all of their official associates who were with them at that time:

"Rookery space occupied by single seals.- When the adult males and females, 15 or 20 of the latter to every one of the former, have arrived upon the rookery, I think

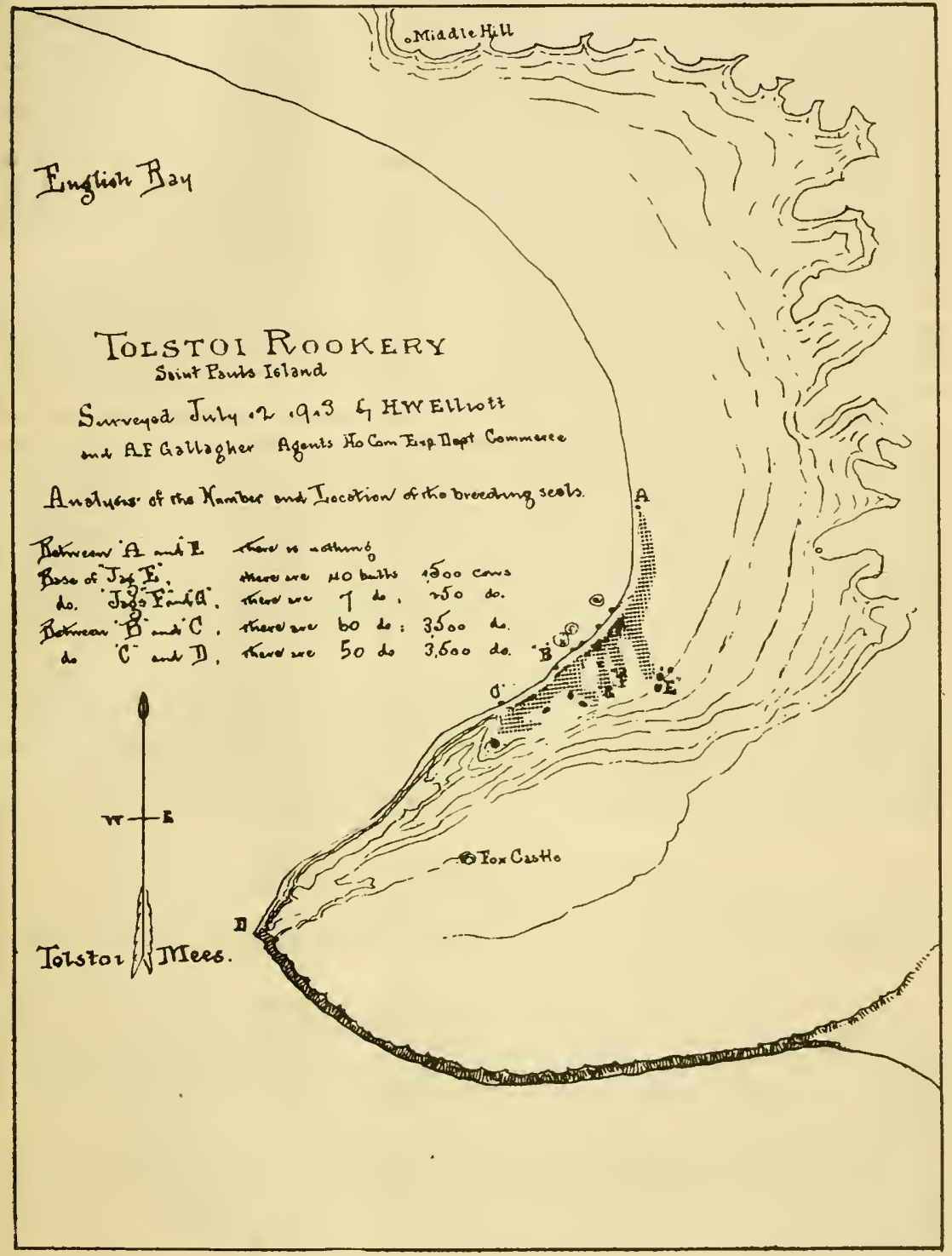

an area a little less than 2 feet square for each female may be considered as the superficial space required by each animal with regard to its size and in obedience to its habits; and this limit may safely be said to be over the mark. Now, every female or cow on this 2 feet square of space doubles herself by bringing forth her young, and in a few days or a week, perhaps, after its birth the cow takes to the water to 
wash and feed and is not back on this allotted space one-half of the time again during the season. In this way is it not clear that the females almost double their number on the rookery grounds without causing the expansion of the same beyond the limits that would be actually required did they not bear any young at all? For every 100,000 breeding seals there will be found more than $\$ 5,000$ females and less than 15,000 males; and in a few weeks after the landing of these females they will show for themselves - that is, for this 100,000 - fully 180,000 males, females, and young, instead, on the same area of ground uccupied previously to the birth of the pups.

"It must be borne in mind that perhaps 10 or 12 per cent of the entire number of females were yearlings last season and come up onto these breeding grounds as nubiles for the first time during the season-as 2-year-old cows. They, of course, bear no young. The males, being treble and quadruple the physical bulk of the females, require about 4 feet square for their use of this same rookery ground, but as they are less than one-fifteenth the number of the females-much less, in fact-they therefore occupy only one-eighth of the space over the breeding ground, where we have located the supposed 100,000 . This surplus area of the males is also more than balanced and equalized by the 15,000 or 20,000 2-year-old females which come onto this ground for the first time to meet the males. They come, rest a few days or a week, and retire, leaving no young to show their presence on the ground.

"The breeding bulls average 10 feet apart by 7 feet on the rookery ground; have each a space, therefore, of about 70 square feet for an average family of 15 cows, 15 pups, and 5 virgin females, or 35 aninials for the 70 feet-2 square feet for each seal, big or little. The virgin females do uot lay out long, and the cows come and go at intervals, never all being on this ground at one time, so the bull has plenty of room in his space of 70 square feet for himself and harem.

"Taking all these points into consideration, and they are features of fact, I quite safely calculate upon an average of 2 square feet to every animal, big or little, on the breeding grounds at the initial point upon which to base an intelligent computation of the entire number of seals before $1 \mathrm{~s}$. Without following this system of enumeration a person may look over these swarming nyriads between Southwest Point and Novastoshnah, guessing vaguely and wildly at any figure from 1,000,000 up to 10,000,000 or $12,000,000$, as has been done repeatedly. How lew people know what a million really is! It is very easy to talk of a million, but it is a tedious task to count it off, and makes one's statements as to 'millions' decidedly more conservative after the labor has been accomplished." (Transcript from the author's field notes of 1874. Nah Speelkie, St. Paul Island, July 12.)

I am satisfied to-day that the pups are the sure guide to the whole number of seals on the rookeries. The mother seals are constantly coming and going, while the pups never leave the spot upon which they are dropped more than a few feet in any direction until the rutting season ends; then they are allowed, with their mothers, by the old bulls to scatter over all the ground they want to. At this date the compact system of organization and massing on the breeding gromnds is solidly maintained by the bulls; it is not relaxed in the least until on and after July 20.

\section{CENSUS OF POLAVINA ROOKERY.}

[Field notes to accompany the chart and survey of condition of Polavina (proper) rookery, St. Paul 1sland, Pribilof Group, July 15, 1913, by Henry W. Elliott and A. F. Gallagher, special agents, House Committee on Expenditures in the Department of Commerce.

(The condition of the rookery, when comparison is made with that of 1890 , is founded upon the published official survey made by Henry W. Elliott and Charles J. Goff, July 10, 1890, and duly published as House Document 175, Fifty-fourth Congress, First Session, pages $31,32,33$.

Before we reach station $\mathrm{F}$, of the 1890 survey, we find two harems located under the bluffs of the hauling grounds of 1890 , on the grand parade. There are 14 cows and 2 bulls in these harems, being all the life there.

We proceed along from that station, toward jag 4 , at the base of which we find one full harem-a bull with about 80 cows; 1 bull with 7 cows, and 1 bull with 1 cow, with no "polsecatchie," and no idle bulls in sight. 
Next, we come to jag 3, of the 1890 survey. We find within its borders 7 bulls with about 600 cows - not a young bull in sight and no polsecatchie. We also find 1 bull with 1 cow under jag 2 .

Under jag 1 we find 5 bulls and about 175 cows.

Coming now to the "grotto," we find 1 bull and about 30 cows, there being 22 pups here.

At Polovina Point, and right on the summit of the point, we find 8 bulls and about 200 cows, with 3 young 6 -year-old bulls in the water bclow and a small band of holluschickie, the number of which it is hard to estimate, as they play in the surf and orer the rocks awash.

From Polovina Point we proceed westward and around to the finish of this rookery's sea margin at the intersection of the sand. Here we observe the greatest massing on this rookery, the number of which we estimate at about 50 bulls and about 7,000 cows. A mere handful of holluschickie are seen here, no young bulls, no polsecatchie, and only two or three 6-year old bulls in the water. These bulls are massed within an area of 500 feet from the point and lay up in the old half-moon form on the original rookery, where 240,000 cows and pups laid 40 years ago. From this small nucleus of 1913 it is very likely that the withered Polorina oak of 1874 will again grow. ${ }^{1}$

It is also interesting, as we close this survey of the St. Paul rookeries with this one of Polorina, to note the fact that as the rookery lay in 1874 as a half-moon on the side of a gently sloping hill up from the sea, so now it seems to start anew after one year's rest. The same order of growth seems instinctively to show itself here by the massing of these harems as described above.

It can not be overlooked as we write these notes, closing this hand-to-hand examination of every foot of these Pribilof rookery margins, that the young male life which was sought to be reestablished by the Hiteheock rules in 1904 is wholly missing. Only here and there and at rare intervals do we see a roung 5 or 6 year old bull. Had those rules and regulations of 1904 been faithfully observed, there would have been thousands of them at the rookery margins at this hour and in their rear.

We also have to say, in connection with the work done this morning at Northeast Point, that that total absence of fighting bulls and tearing of cows to pieces and trampling of pups has been universal throughout the entire survey of all these Pribilof breeding serais : $:-9 m$ start to finish.

\footnotetext{
1 With regard to the form of this seal life on Polorina in 1872-1874, as contrasted with the eondition it is now in, the following official record $i$ made of it (p. 42, H. Doc. No. 175, 54th Cong., 1st sess.), to wit:

"The ringing, iron-like basalt ic foundations of the island are here (Polovina) setting up boldly from the sea to a height of 40 or 50 feet, black and purplish-red, polished like ebony by the friction of the surf, and worn by its agency into grotesque arches, tiny caverns, and deep fissures. Surmounting this lava bed is a cap of ferruginous cement and tufa from 3 to 10 feet thick, making a redish floor, upon which the seals patter in their restless, never-ceasing evolutions, sleeping and waking, on the island. It is as great a pingle parade platean of polished cement as is that of the reef.

"The rookery itself $* * *$ is placed at the southern termination and gentle sloping of the long reach of Polovina's bluff wall, which is the only cliff between Lukannon and Novestoshnah * * *.

"It presents itself to the eye with great scenic effect, *** covered with an infinite (letail of massed seals in reproduction ***,"

Then again, in July, 1890, the following contrast is drawn, looking back to $1872-1874, \mathrm{p}$. 44, following the above:

"So when I regard this ground to-day, after an interval of 16 years since my last survey, I find a square declaration from the ground itself of loss to this rookery of one-half of its female life, while its brceding bulls are not equal to one-fifteenth of their number here in 1872. Then, too, the utter absence of a young bull on the vacant spaces in the rookery or in the water at its sea margin; and, still more remarkable in contrast, that pronounced ut ter absence of the holluschickie from their grand parade ground here-that silent, empty space before me on which at this time in 1872 anywhere from 75,000 to 100,000 holluschickie were trooping in and out of the water frolicking in tireless antics one with another or wrapped in profound sleep ***."
} 
CENSUS OF LITTLE POLOVINA ROOKERY.

[Field notes to accompany the chart and survey of condition of Little Polorina rookery, St. Pauls Island, Pribilof group, July 15, 191:3, by Henry W. Elliott and A. F. Gallagher, special agents House Committee on Expenditures in the Department of Commerce.]

(The condition of the rookery, when comparison is made with that of 1890 , is founded upon the published official survey marle by Henry W. Elliott and Charles .j. Goff, July 10, 1890 , and duly published as House Document 17j, Fifty-fourth Congress, first session, pages $31,32,33$.

We begin our survey at station $C$, and up to station $B$ every vestige of seal life has disappeared, as compared with the survey of 1890 .

From the latter station we find 21 bulls and about 800 to 1,000 cows; "no polsecatchie in the rear," and, in fact, no young bulls anywhere in sight. The life then abruptly ceases and from this station to station D not a vestige remains. There are no holluschickie in or around this rookery or in sight. ${ }^{1}$

To recapitulate.-For Little Polovina, July 15, 1913, we find 21 bulls, 1,000 cows, 900 pups; for Polovina rookery, July 15, 1913, we find 72 bulls, 5,005 cows, 7,200 pups. On both Polovinas, season of 1890 , there were 1,850 bulls, 71,000 cows, 70,250 pups; season of 1874 , there were $S, 600$ bulls, 150,000 cows, 148,500 pups.

\section{CENSUS OF NOVASTOSHNAH ROOKERY.}

(Field notes to accompany the chart and survey of condition of Novastoslunah rookery, St. Panls Island, Pribilof Group. Tuesday, July 15, 1913, by Henry W. Elliott and . 1. F. Gallagher, special agents IIouse Committee on Expenditures in the Department of Commerce.]

(The condition of the rookery, when comparison is made with that of 1590 , is founded upon the published and official survey made by Henry W. Elliott and Charles J. Goff, July 10, 1S90, and duly published as House Document 175, Fifty fourth Congress, first session, pages $31,32,33$.

As we open and begin our review of this rookery of Novastoshnah to-day, we start in at Websters Point and traverse the abandoned hauling grounds of 1874 to Pulpit Point. At station A is where the breeding grounds of 1574 ended on this side of Novastoshnah. From Pulpit Point to the sand beach, between station $B$ and station $A$ of the 1890 surrey, not a single seal is in sight to day. Crossing over that sand beach to station $\mathrm{A}$, we find the small hauling grounds of 1590 entirely abandoned, no sign of any holluschickie on them, not a single polsecatchie; a small pod of holluschickie is hauled out on rocks awash under $\mathrm{A}$, which are the last remnant of thousands once

1 In 1872-1874 there were two great hauling grounds which were never visited at any time by the natives who were getting seals for the lessees; they were never even looked at or thought of by anybody when Elliott was surveying the herd then-the Southwest Point hauling grounds, where at least 60,000 to 80,000 large 3 and 4 year old seals gathered fairly alone by themselves, and the Dalnoi hauling grounds, just midway between Little Polovina and Novostoshnah.

The natives told us that they had first "driven" the "big seals" at Southwest Point in 1856 ; they had by 1889 completely finisbed the life there, and to-day, July 24,1913 , they told us that not a seal has ever hanled out there since.

They made their last drive from Dalnoi in 1896; not a seal has hauled there since; in 1890 they drove less than 100 from it. This shrinking to disappearance of the surplus male life long, long before any great loss of the female life has never aroused that interest which it deserved by the casual observers who have been on these islands at intervals since 1590 to date. The natives, however, in 1890 were much concerned about it, and declared that the work of the pelagic sealer was then not near as deadly for the seal herd's existence, nor was the killing on land as it harl been conducted ever since 1883.

In 1872-1574 they declared that under the Russian régime, 1800-1834, the continued annual killing of the young male seals (just as the lessees have been killing them since 1s-1-1909) had so reduced the herd that they were compelled to give it a 10 vears' rest; they said that in 1834 there were "only about 500 cows alive on Polovina," etc. (See Elliott's Mono. Seal Islands, 1852, 10th Census, p. 49.) 


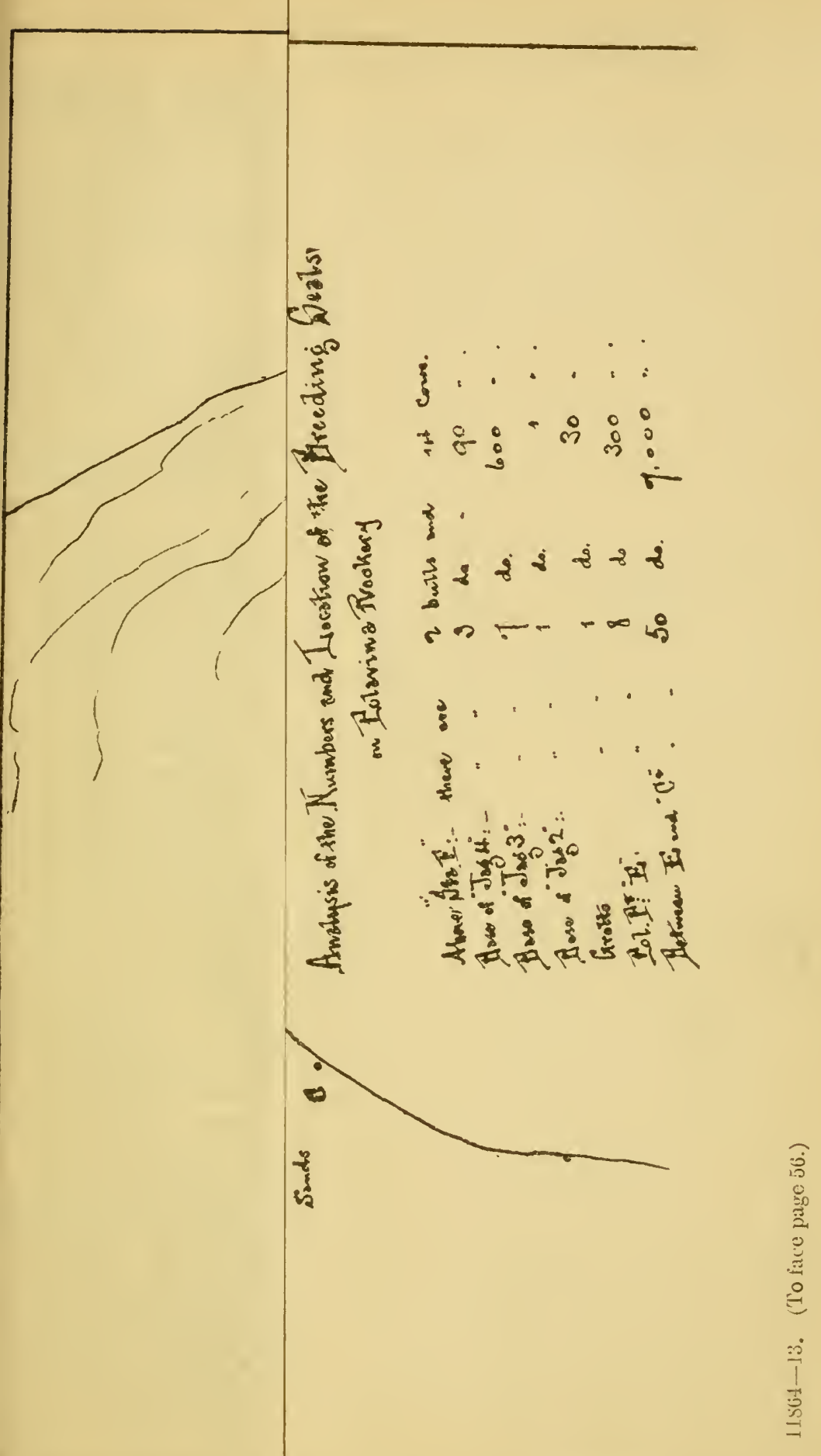




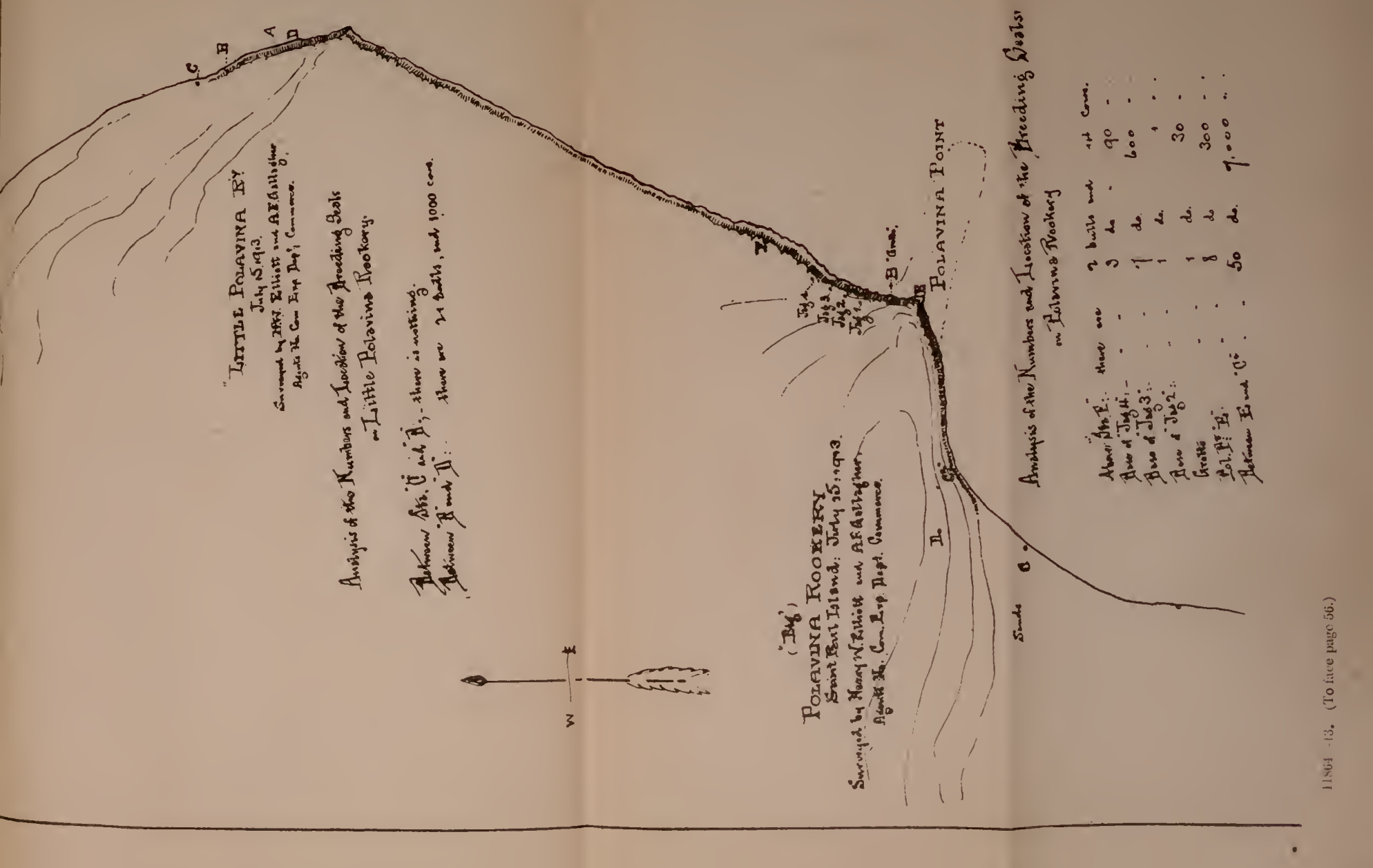


existing and swarming on that immense sweep from Websters Point. To the crest of Hutchinsons Hill from here it is overgrown with grass, and it was totally abandoned by the seals evidently many vears ago.

On reaching station A we find the first seals surviving from the survey of 1890 . We find here the best depth of a single gathering of the herd that we have seen outside of the massing under Garbotch; it is at least five harems deep. We find from 750 to 800 cows and from 38 to 40 bulls. On the water's edge we find four or five 6-year old bulls.

This feature of normal massing of harems at this point is immediately lost as we proceed toward Sea Lion Neck, or station B, and on reaching that foot of it we find a second semimassing, three harems deep, of about 120 cows. On the rocks of this station is the first noteworthy squad of holluschickie that we have encountered, perhaps 200 or 300 of them. We find here about 35 bulls and about 800 cows. We find here the first big sea lion seen thus far in our survey.

From station B to the neck it is all abandoned, even erery sea lion has gone, with the exception of about 100 holluschichie and two ragged harems about midway between the neck and this station.

From the neck we go to Northeast Point and find nothing, ${ }^{1}$ thus closing the entire aggregate of breeding seals on the east margin as compared with the survey of 1890 .

On our arrival at the point we find a rookery of sea lions which closely resembles the aggregate of 1890 ; in other words, there may be 1,500 of them. There is certainly a fine agregate and no danger of extermination to this life on the island.

From the Point we proceed west to the Asses Ears. Under the immediate flank of them and the sea-lion rookery, we encounter a ragged seal-harem, together with on idle bull in the rear.

Starting at the foot of station $\mathrm{L}$, we meet the first band of breeding seals where none hauled in 1890 , existing on grounds not occupied in 1890 and as we proceed west, we find 7 bulls and about 250 cows, with one idle bull on this ground abandoned in 1890, and now reoceupied in 1913, which is the first example of this kind found thus far on the rookeries. There are no polsecatchic, no 6-ycar-old bulls; no fighting, and no evidence of dead, or sick, or trampled pups. All look healthy and well.

Immediately above us, as we go west, is the first noteworthy pod of holluschickie hauled out, consisting chiefly of yearlings; we should

\footnotetext{
1 In view of that complete elimination, the following is recorded of it in 1572:

"In view of that complete elimination, the following is recorded of it in 1572 :
"There is no impression on my mind really more vivid than is the one which was planted there during the afternoon of that July day (1872) when I first made my survey of this ground. lndeed, wlienever I pause to think of the subject this great rookery of Novestoshnah rises promptly to my view, and 1 am fairly rendered voiceless when 1 try to speak in definition of the spectacle. In the first place this slope from Sea Lion Neck to the summit of Hutchinsons Hill is a long mile, smooth and gradual from the sea to the hill top. The parade ground lying between is also nearly three-quarters of a mile in width, sheer and unbroken. Now, upon that area before my eyes, this day and date of which 1 have spoken, were the forms of not less than three-fourths of a million of seals. Pause a moment; think of that number; threefourths of a million seals moving in one solid mass from sleep to frolicsome gambols, backward, forward, over, around, charging and intercharging their heavy squadrons until the whole mind is so confuscd and charmed by the rastness of mighty hosts that it refuses to analyze any further. Then, too, I remember that the day was one of exceeding beauty for that region. It was a swift alternation overhead of those characteristic rain fogs, between the succession of which the sun breaks out with transcendent brilliancy through the misty halos about it. This parade field reflected the light like a inirror, and the seals when they broke apart here and there for a moment, just enough to show its surface, seemed as though they walked upon the water. What a scene to put upon canvas, that amphibian host involved in those alternate rainbow lights and blue-gray shadows of the fog." (Monograph Seals Islands of .1laska, 1872-1Sit;

Elliott.)
Every foot of that ground thus described above is covered with grass to-day, and not a single hatuling squad of bachelor seals seen upon it, but one small bunch of less than 4,500 . (11. W. E., July 15, 1913.)
} 
judge there are about 1,000 or 1,200 of them in this batch. Just before reaching these holluschickie, we find the first dead pup that we have seen thus far, although, naturally, there must be many more.

As we proceed to station $\mathbf{M}$, passing these holluschickie, we find 24 bulls and about 700 cows. The holluschickie which all ran down to the sea and swam off as we passed by, are now rounding the point in front of us, a few hauling up again on the rocks immediately under station $\mathrm{M}$. We find among them 7 or 8 young idle bulls and these are the first ones we have found thus far on this rookery.

At station $M$ we find another semimassing of harems, which we count, and estimate as containing 23 bulls and from 2,300 to 2,500 cows. Back of this massing are two pods of holluschickie, which we estimate to consist of about $100 \mathrm{in}$ one pod, and the other of about 2,500 or 3,000 - all going to the water-nearly all yearlings, very few 6-year-old's, very few polsecatchie, as they show themselves to us as they are now going into the water by us. To these figures we add about 430 cows at the base of this station, and 10 bulls. In between we find a couple of ragged harems, 2 bulls and 14 cows.

Between stations $\mathrm{M}$ and $\mathrm{N}$ the holluschickie which are rumning out now from the pods which we have just stirred up, make an exhibition of at least 4,000 young animals since they started; chiefly yearlings. (More than 200,000 of them were on this particular area under Hutchinson Hill, in Julv, 1874.)

From station + we now proceed to jag 1 , of the 1890 survey under the foot of Hutchinson Hill, and at the base of which lies a mass of breeding seals, of about 12 harems deep. 'This is the deepest and the largest aggregation of that normal massing of breeding seals which existed here in 1874, that we have seen thus far, and which now is only faintly shadowed out by it. From th is outside point of enumeration, since it is impossible to properly get in among and count those bulls as they lie to-day, nor is it sensible or advisable to do so, it would appear that there are from 65 to 75 bulls, but it is impossible to state the exact number, we will therefore define the boundary as being substantially the base of jag $A$ in the 1890 survey, and cut down to slightly within the limits of the 1874 survey.

From here we will pass to the summit of jag 1 , of the 1890 survey, and look down upon this mass of breeding seals at the foot of Hutchinsons Hill, in order that we may make a sensible approximation of the numbers massed therein. Wre observe along here two more dead pups. Reaching this summit (jag 1) we look down and find that the massing follows the lines of 1890 , reaching from the point of jag 2 over to the limits of jag 1 , but within the lines of the survey of 1874. It again falls away into a series of ragged harems, and dies out before we reach station $\mathrm{N}$. It is massed approximately as the normal massing of 1874 , as far as it goes, covering at least 520 feet of the sea margin, running back of jag 1 of 1890 at least 200 feet, with 10 or 12 harems deep, fading away toward jag 2, and jag 3 being entirely eliminated and lost in this survey. ${ }^{1}$ We find in this

1 Tonching this complete elimination of seal life as noted here in 1913, it is interesting to contrast the deseriptiun of it as it appeared on this spot in 1590 , or 23 years ago.

"As this great ruokery was the object of my chief admiration in 1872 , now it, in 1890 , again becomes the object of my chief concern-not admiration to-day, but of my chief pit $y$ for this breeding ground has suffered a startling loss of life during the last 18 years. It presents the deepest shadow now to that sunshine inwhich I saw it 1s years ago, as I then walked around and over it. I surveyed the ground last summer (July, I890) as one would loeate a graveyard; not more than a suggestion of the massed life of 1872 have 1 been able to see within its desolate area. That ground which I have deseribed in $1872-1874$ as covered with hosts of 
massing of breeding seals approximately 6,500 cows and about 125 bulls, with 10 "idle" bulls in the rear, but no "polsecatchie" about.

The survey of jag 3 of 1890-that is, the life line of the survey of jag 3 of 1890 to-day-is now represented by a fringe of harems at the surf margin, consisting of 24 or 25 harems and about 400 cows; no idle bulls.

We find also a large gathering of sea lions, bulls, and cows just below the breeding seals at the surf margin on the rocks, there being not less than 300 or 400 of them.

Proceeding to station $\mathrm{O}$, we find about 32 bulls and 600 cows. From $\mathrm{O}$ to $\mathrm{P}$ we find about 32 bulls and about 600 cows. At the foot of station $P$ there are about 14 bulls and about 250 cows, with two idle 6-year-old bulls in the rear, but no polsecatchie.

As we proceed from $\mathrm{P}$ to $\mathrm{Q}$, we find 15 bulls and about 400 cows. That closes the life, which abruptly ends at station $\mathrm{Q}$.

Beyond, as we progress to station $R$, we find 10 bulls ( 6 of which are idle), and four harems at the northwest shoulder of station $R$, containing about 50 cows; the entire life of 1890 being reduced to that! On the reef at the foot of this northwest shoulder are three or four hundred holluschickie playing on the rocks, with a few sea lions.

It may be said here, in review, that the sea lions that we hare seen at the foot of the station that we have just left undoubtedly belong to the rookery at Northeast Point, and the aggregate number of them that we have had in view clearly proves that the sealion life of to-day is quite up to the record of is90.

We now proceed from station $\mathrm{R}$ to station $\mathrm{S}$ on the northwest shoulder, and we find a series of pocket harems at the surf wash, consisting of two bulls, with about 140 cows, and 6 bulls with about 250 cows, plus one bull with three cows, in the pocket right at the extreme point of the northwest shoulder, together with one injured or crippled bull.

From station $\mathrm{S}$ we proceed to station ' $\mathrm{T}$, where we find 5 bulls and about 60 cows under the last-named station.

We now sweep around to stations $U$ and $V$, and enumerate as follows: Seven bulls plus 2 bulls and about 300 cows, plus 10 bulls and 350 cows, with 2 polsecatchie swimming at the water's edge (the first we hare seen this morning), plus about 25 bulls and orer 1,500 cows, with one 6-year-old bull in the rear, plus 4 bulls and 65 cows, plus 3 bulls and about 50 cows, and plus 5 bulls and about 250 cows.

Between station $V$ and station $W$ nothing appears in sight. At stations $\mathrm{U}, \mathrm{V}, \mathrm{W}$, and $\mathrm{X}$ there is a complete abandonment of all that ground by the seal life; not a single seal on the rocks or on the hauling grounds or in sight! From station $\mathrm{X}$ to the middle shoulder

amphibians, is again before me to-day, with not a single herd of seals upon it-actually green with upspring ing grass and colored and flecked with raried flowers." (P. 47, H. Doc. No. 175, 54th Cong., 1st sess.)

"The sound which arjse in 1872 from these great breerling herds of the fur seal when thousands upon tens of thousands of active, angry, and vigilant bulls were roaring, chuckling, piping, and multitudes of seal mothers were calling in hollow bleating tones to their young, that in turn responder incessantly, is simple defiance to verbal description. It was at a slight distance softelled into a deep booming as of il cataract. **** Night and day throughout the season of 1572 this din upon the rookeries was steady and constant." (Pp. $41-42$.

"I have heard it with a light, fair wind as far as 6 miles out from land in the sea. And even in the thunder of the surf and roar of heavy gales it would rise up and over all to rour ear quite a considerable distance away. It was the monitor for which the seis captains anxiously strained their ears when they had run their 'dead reckoning' up and were 'laying to' in the fow, waitung for' it to rise so they coull get their bearings on the land." (Elliott, Mono. Seal Islands, 1S72-1874.) 
we now proceed, and right under the foot of the middle shoulder since we left station $W$ the first seal life reappears, and we find here 3 bulls with about 50 cows.

From the middle shoulder, where we have just enumerated this appearance of the seal life since we left station $W$, we now traverse the finish of this coast line of Novastoshnah, to the south shoulder, and as we go we observe not even a shadow of this life-there is not a single seal from our starting point to the finish at station B; not a sign of seal life.

As we look back, over and along the whole route that we have traversed this morning, in and out of these pocket harems, and over the ground covered by the survey of 1890, we are impressed with the fact that the seal life as we see it now is far short of that surplus male life which nature intended should surround and serve as sires for the breeding harems. Throughout this entire circuit we have been impressed with the fact that the number of cows in harems are abnornally large. They are nearly three times greater than the proportion which is naturally found in their normal condition. The bulls evidently have had no real fighting to maintain and seeure their positions, sinee very few of them have any combat marks. The result is that we find an aggregate of very large harems, spreading out into scattered or ragged harems on either side, in which the service is often devolved upon the single bull, unless assisted, far beyond his power, since many of these larger harems, numbering not less than 120 to $130 \mathrm{cows}$, were observed.

In a very large majority of the pocket harems the families exceeded 60 to 75 cows; the ragged harems of 5 to 10 cows, surrounding them, make up the total of active bulls as against the total of breeding cows, a misleading summing up; because, really, the bulls which are in active service within the lines of the large harems are doing three and four times the work they should do, while the others are practically idle. Then, also, we observe, as we complete the circuit, that same crowding unnaturally, by the breeding seals, to the surf line, instead of lying up in a normal manner, 10 or 12 feet back from the surf wash at high tide. That is due undoubtedly to the incessant hunting and chasing of these holluschickie by the natives and pup counting along the lines of these harems and the sea margin, as the lessees urged the native drivers to get them or the agents directed the "live-pup counts"-all wrong.

From here on the north, middle, and south shoulders the small hauling of holluschickie reported in 1890 has entirely disappeared, and it seems to now be entirely confined to that single exhibition, as above cited, at stations $\mathrm{M}$ and $\mathrm{N}$.

We might add that this morning we have seen the first badly injured bull thus far seen on our survey, and that we have not seen a single exhibition of "bulls fighting for possession of the females" or of "cows being torn to pieces" by the bulls, or of "pups trampled to death" on the rookery.

We have carefully looked into nearly every one of the harems, and we have not seen more than one dead pup. We have not seen the slightest evidence of any sickness or distemper among these seals, old or young. 


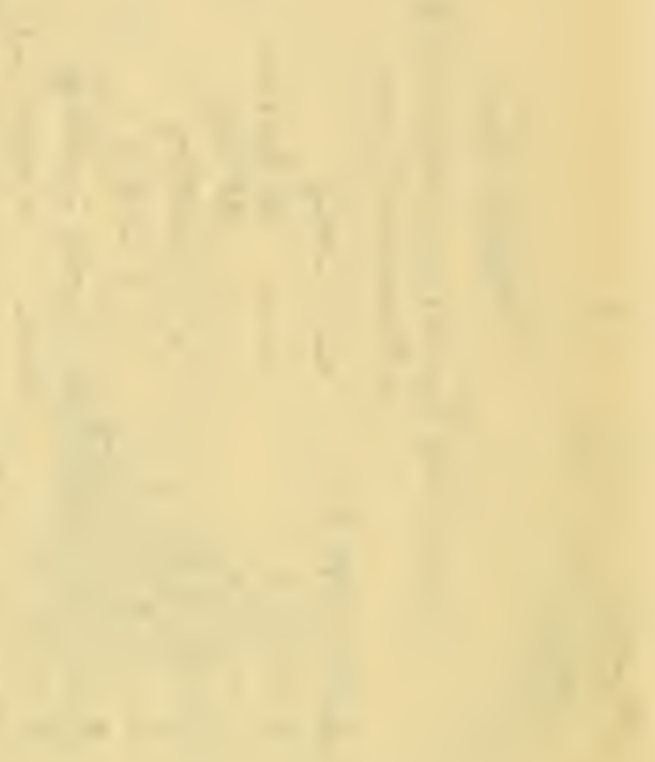




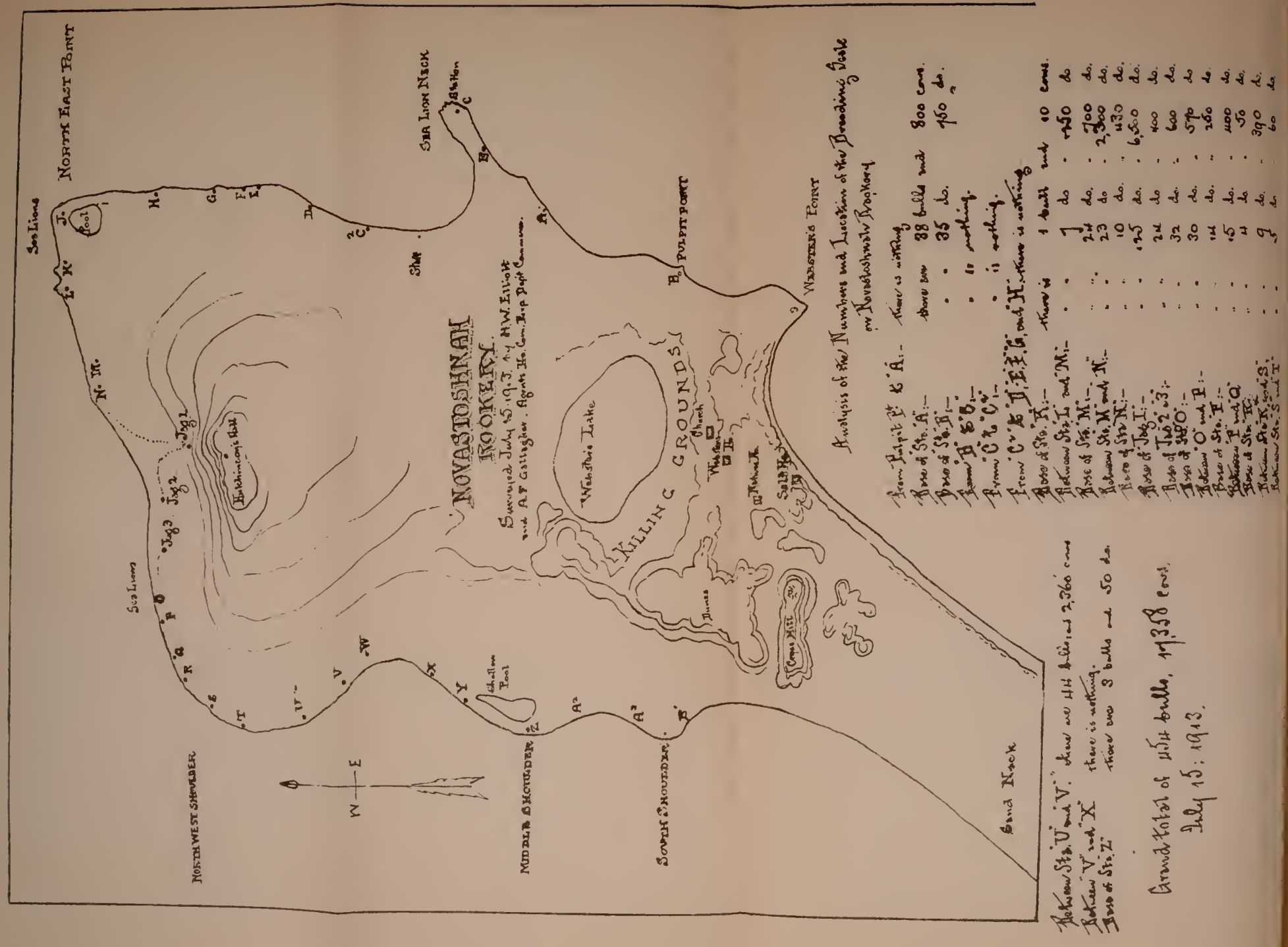


To recapitulate.-For Novashstoshmah rookery: July 15, 1913, we find 454 bulls, 17,358 cows, 15,622 pups. Season of 1890 there were 2,600 bulls, 103,937 cows, 95,000 pups; season of 1874 there were 34,000 bulls, 600,000 cows, 540,000 pups. $^{1}$

CENStS OF REEF AND GARBOTCH ROOKERIES, WITH SEEYITCIIIE KAMMEN.

[Field notes to accompany the chart and survey of condition of Reef and Garboteh rookeries, St. Pau] Island, Pribilof Group, Thursday, July 10,1913, by Henry W. Elliott and A. F. Gallagher, special agents of House Committee on Expenditures in the Departinent of Commerce.]

(The condition of the rookery when comparison is made with that of 1890 is founded upon the published official survey made by Henry W. Elliott and Charles J. G(vf, July 10, 1890, and duly published as House Document No. 175, Fift y-fourth Congress, first session, pages 31 , $32,33$.

Beginning with our survey this morning, we find that the thin fringe of breeding seals which laid under the eap at Garbotch in 1890 has practically disappeared, with the exception of four or five small harems, until we reach the line under the Black Bend. The entire disappearance of that breeding life which was enumerated in 1890 as jags $R, Q$, and $P$ has taken place. No massing or suggestion of massing of a single harem occuts until we reach jag $Q$ of the 1890 survey. The Zoltoi bluffs to our back, on which a few hundred holluschicke hauled out during the summer of 1890, has been entirely abandoned by those animals, and the natives say that no drive has been made from there since 1896 .

As in 1890 not a single killable seal or holluschack has hauled on Zoltoi sands up to this date. That famous and beautiful gathering place of the bachelors has been completely abandoned by them since 1890.

Upon the surf margin of Black Bend we find to-day a single fringe or line of six widely separated small harems-one being a full harem, one a ragged harem, and the others controlled each bF a single bull with four to fire cows. There are no roung male bulls in sight. There are no polsecatchie at the water's er!ge or in the rear. The entire brecding ground area is abandoned as marked on the 1890 survey save these noted exceptions.

Proceeding on our way, we find from the Black Bend that the breeding seals on jags $\mathrm{P}$ and $\mathrm{Q}$, of 1890 , hare entirely disappeared, and the sole survivors are now exhibited by that thin fringe of harems which we have just mentioned. From the summit of the Old John Rock, as we proceed, we find that the first massing which in the slightest degree resembles the normal eonclition of these rookeries is found at the foot of Old John Rock and to the southward to Gerboteh Bight, a distance of some 600 feet: here the harems are banked three and four bulls deep from the water's edge. The bulls are seattered at intervals of 20 to 30 feet apart (the normal distance being from 7 to 10

1 The "podding" of the pups at Novashstoshnah September, 18:2: "Although the appearance of the holluschickie at English Bay fairly overwhelms the observer with an impression of its countless multitudes, set I am free to declare that at no one point in this cvolution during the reproductive scason liave I been so deeply stricken with the sense of overwhelming cnumeration as I have been when standing on the summit of Cross Hill I looked down to the southward and westward over a reach of 6 miles of alternate grass and sand dune stretches, mirrored upon which were hundreds of thousands of these little black pups spread in sleep and sport within this restricted field of vision. They appeared as countless as the grains of sand upon which they rested." (Ellioit, p. 46, 11. Doe. No. 175, juth Cong., 1st sess.) 
feet, when the herd is in fine form and condition). The cows in the harems present a uniformly rusty tone, which shows that the pups are all born for the season, practically. In the whole field of view under our eyes the proportion of new arrivals among the cows, as is shown by their silvery coats (gray backs and white bellies), is not one in fifty. The bulls appear in good form, not somnolent; and the proportion of young 6 to 8 year old bulls is quite large, though the number, all told, is far below the normal ratio; the cows are exceeding the males far, far beyond the limits of 1872 and 1874 . There is no fighting under our eyes; no bull bears a mark upon his back, sides, or flippers, which is the evidence of fighting, if there be such, or has been such this season on this place. No dead, sick, or trampled pups here; no cows "torn to pieces" by the bulls either; not one.

Looking back and up under the slope of Black Bend to the base of this point of view from Old John Rock, the cap, we find that the entire area of 1890 occupied by breeding seals is reduced to nothing, save those few harems noted thereon by us at the start, on the margin of the scene, until we reach that first point of massing which we have just described. There are no half-bulls in sight at the rear or at the water's margin, and only five or six virile bulls in the rear. As we proceed from Garbotch Bight ${ }^{1}$ onward, jags M, N, and $\mathrm{O}$, of 1890 have entirely disappeared; nothing remains except six massed harems at the foot of jag $M$, and four ragged harems in between, at wide intervals, at the water's edge; from the bight we go to the foot of jags $L, K$, and $J$, of 1890 , and find there is a complete elimination of all of that breeding-seal life save six ragged harems between jag M and the foot of jag L. Upon the ground occupied by the breeding seals in 1890, of jags $K$ and $\mathrm{L}$, is to-day a band of holluschickie, which we find to be composed nine-tenths of yearlings and the balance 2year-olds, with the exception of a few 6 -year-old and 5 -year-old bulls hauled with them.

As we proceed we find that jags $J$ and $K$ are entirely eliminated, and in lieu thereof 10 harems are now scattered over the vacant interval, 3 of those harems being normal and the others ragged. We see no half-bulls in the rear or on the water's edge, nor are there any idle bulls.

As we proceed to the finish of the Garbotch line we find that jags I and $H$ of 1890 have completely disappeared, save at the extreme water's edge, and down there and between the lava pockets are 8 or 10 massed harems and 7 or 8 ragged or scattered ones, with no evidence of an idle bull or the appearance of polsecatchie in the water or at the rear.

This completes our survey to-day of the breeding line of Garbotch. From there we proceed to Ardiguen, on the Reef Point.

1 This desolated area was not so in 1872-157t, the following attests: "The adaptation of this ground of the Reef Rookery to the requirements of the seal is perfect. It so lies that it falls gently from its high Zoltoi Bay margin over Garbotch Bight on the west to the sea on the east; and upon its broad expanse not a solitary puddle of mud spotting is to be seen, though everything is reeking with moisture and the fog even dissolves into rain as we view the scene. Fvery trace of vegetation upon this parade has been obliterated; a few tufts of grass, capping the summits of those rocky hillocks indicated on the eastern and middle slope, are the only signs of botanical life that the seals have suffered to remain."

A small rock (see Vichie Kammen) five or six hundred feet away and out to sea is also covered with the black and yellow forms of fur seals and sea lions. It is environed by shoal reefs, rough and kelpgrown, which navigators prudently avoid.

"This rookery of the reef proper has 4,016 feet of sea margin, with an average depth of 150 feet, making ground for 301,000 breeding seals and their young. Garbotch Rookery has 3,606 feet of sea margin, with an average depth of 100 feet, making ground for 183,000 breeding seals and young; an aggregate for this great Reef Rookery of 484,000 breeding seals and young. Heavy as this enumeration is, yet this aggregate only makes the Reef Rookery third in importance compared with the others which we are yet to describe." (Monograph Seal Islands of Alaska: Elliott: 1874, p. 51.) 
To-day Ardiguen, or jag G of the 1890 survey, has been reduced to a fringe of 12 or 13 scattered harems, all resting right at the water's edge. All massing here, or rookery appearance of 1890 , has disappeared.

We now proceed to the Reef Point, where we find that jags $F$ and $\mathrm{E}$ have receded to the water's margin, showing a fringe of 25 or 30 harems, 6 or 7 of which are abnormally large, 1 having at least 200 cows, another 60 , and 2 or 3 of them with 30 or 40 . We see here the first half-bull observed to-day and which bull fled from the rear and took to the water. We also see another half-bull in the water and one 6-year-old idle bull, the first idle 6-year old seen. There is no evidence of fighting and no evidence of trampled pups or cows being torn to pieces seen on the survey thus far.

As we proceed we find that jag $\mathrm{D}$ and jag $\mathrm{C}$ of 1890 are reduced to six massed harems at the water's edge, the bunching at the foot of jag D representing, collectively, about 500 cows, consisting of five or six harems bunched, another representing three or four massed harems, another representing three or four, another representing two, and another representing six or seven, the whole aggregate not exceeding 1,000 cows and 25 or 30 bulls. We also observed here two polsecatchie or 5-year-old bulls lying in the rear, but no others in sight, either at the rear or at the water's edge. There are only four or five idle bulls lying in the rear. The whole area covered br breeding seals on these jags of 1890 is abandoned and reduced to this number and appearance to-day.

We now proceed to the consideration of jags $B$ and $A$, as we shall view them from the Reef Pinnacle, from which point they were best seen in 1890.

From the Reef Pinnacle we now find that they have been completely eliminated, and in lieu thereof there are seven scattered harems along the water's edge with perhaps 12 or 15 bulls. Around the pool is clustered a herd of holluschickie, with the usual proportion of $1,2,3,4$, and 5 year old male seals, this being the only band of holluschickie viewed since we left Garbotch, and the number may possibly be as high as 1,200 or 1,300 , but these are all the nonbreeding seals that are in evidence to-day on the Reef Point and Garbotch hauling grounds.

From the foot of jag A to the second point of 1890 , we will now proceed; but as we do, we stop at the summit of the Grand Parade Pinnacle, over which the eye can sweep upon the famous hauling grounds of 1874, where, from the foot of Fox Hill over to Garbotch Bight down to the Reef Point, and from shore to shore, the entire area was bare of every vestige of vegetation on the earth and lichens upon the rocks; and, upon which at any time during this period in 1874 , not less than a hundred and fifty to two hundred thousand holluschickie were hauled out, moving hither and thither in ceaseless marching and countermarching, or else spread in fitful sleep and uneasy awakening, so characteristic of this animal when on land. ${ }^{1}$

\footnotetext{
1 With regard to this condition of complete elimination of seal life to-day, as contrasted with its appearance on these grounds in 1874. the following description of it is made in Elliott's Monograph Seal Istands,

under date of July 22,1874 , (pp. 50-51):
"These Zoltoi sands are, however, a famous rendezvous for the holluschickie; and from them during the season the natives make regular drives, having only to step out from their houses in the morning and walk but a few rods to find their fur-bearing quarry.

"Passing over these sands on our way down to the Reef Point, we quickly come to a basaltic ridge or backbone, over which the sand has been rifted by the winds, and which supports a rank and luxuriant
} 
To-day, every foot of that ground so occupied and swept in 1874, and the rocks then polished, is now covered by a luxuriant growth of mosses, giasses, biennial and perennial flowers. Were it not for the matted fur and hair that is everywhere under foot and through which this regetation reaches for growth, the statement made above would be fairly unbelievable; unbelievable because all of the holluschickie seen to-day from the beginning to the end of this survey have been confined to two small pods, one hauled out at Garbotch, not exceeding 400 or 500 , and the other below the reef crest and around the pool, not exceeding 1,500 or 2,000 . These are liberal estimates, and this statement of the utter abandonment of the sealing ground is a fact of positive record and indisputable evidence as this writing is made.

To resume this survey of the breeding lines which we closed at jags $A$ and $B$ of 1890 , we find that the surviving seals are now bunched in 6 or 7 harems at the foot of those jags; one of these harems being buncherl or massed with at least 250 to $300 \mathrm{cows}$, another even larger, another of $50 \mathrm{or}^{2} 60$ cows, and two or three ragged harems, the whole aggregate being not less than 1,000 eows, with this full disproportion of bulls in evidence. There is only one young 6 -year-old bull seen in the water, and there are no polsecatchie in the rear.

Between the second point and the foot of jag $\mathrm{A}$ is a succession of 12 or 15 harems, all of them large, with two exceptions, carrying an aggregate of perhaps 450 to 500 cows. There are no young bulls in the water, or idle bulls in the rear, with two or three exceptions.

. From the second point to the first point, with the exception of six or seren small surf-swept harems, consisting of an aggregate of perhaps less than 150 cows, the herd of 1890 has completely disappeared. From the first point, where there are six or seven harems massing and approximately 250 cows, we pass to the foot of Fox Hill, over which area the entire herd of 1890 has disappeared from. Under the foot of Fox Hill are six or seven small harems with perhaps 100 cows; the herd of 1890 has also disappeared completely in that place; not a seal on the margin nor a suggestion of a half-bull in the water, or in the rear. Everywhere a thick sod and flowers growing upon the ground corered by breeding seals in 1874 , growing rank and luxuriant, right down to the surf-swept margins of the standard breeding ground. ${ }^{1}$

growth of the Elymus and other grasses with beautiful flowers. A few hundred feet farther along our course brings us into full view as we look to the south of one of the most entrancing spectacles which these seals afford to man. We look down upon and along a grand promenade ground which slopes gently from the west to the eastward and trends southward away to a parade plateau as smooth as the floor of a ballroom 2,000 feet in length, 500 to 1,000 feet in width, over which multitudes of holluschickie are filing in long strings, or deploying in vast platoons, hundreds abreast in an unceasing march and countermarch. Their breath, which rises into the cold air from a hundred thousand hot throats hangs like clouds of white steam in the gray fog itself; indeed, it may be said to be a seal fog peculiar to the spot, while the din, the roar arising over all defies our description.

"We notice to our right and to our left, the immense solid masses of the breeding seals at Garbotch, and those stretehing and trending around nearly a mile from our feet, far around to the Reef Point below, and opposite the parade ground, with here and there a neutral passage left open for the holluschickie to go down to, and come up from the waves."

In 1890 , on July 10, the following official record of the life on Garbotch and the Reefs is summed up as follows on page 31, Honse Document No. 175, Fifty-fourth Congress, first session:

"Those curious jags of breeding seals which show so plainly on the Garbotch slope form the most striking feature of that changed order of affairs which declares a reduction of more than one-half of the fernales and fully nine-tenths of the males on this rookery.

"Then that splendid parade ground of 1872 is now fairly deserted-grass, moss, lichens, and even flowers are now taking root every where over its polished surface of 1872 -and Zoltoi sands-it has not been visited by young male seals this year during the sealing season-none left to come."

"The whole of this reef neck in 1572 south of Grassy Summit and Fox Hill was entirely bare of grass or of any vegetation what aver except lichens on inaccessible rocks to seals, and tufts of grass on the overhanging points and clif edges of the west shore; but on the 9 th of last $\mathrm{August}$, as 1 stood overlooking the 
To recapitulate.-For the Reef and Garbotch Rookeries, July 10, 1913 , we find 393 bulls, 15,000 cows, 13,500 pups.

CENSUS OF SEEVITCHIE KAMMEN.

(Part of reef.)

[Field notes to accompany the chart and survey of condition of seevitchie Kammen rookery, St. Pauls Island, Pribilov group, Sunday, July 20, 1913, by Henry W. Elliott and A. F. Gallagher, special agents House Conmittee Expenditures Department of Commerce.]

(The condition of the rookery, when comparison is made with that of 1890 , is founded upon the published official survey made by Henry W. Elliott and Charles J. Goff, July 10, 1S90, and duly published as House Document 175, Fifty-fourth Congress, first session, pages $31,32,33$.

The survey of the Recf rookery includes a rock known as Seevitchie Kammen, which is 800 or 900 feet off from the reef and to the southward and at sea.

In 1874 it was covered with the black and yellow forms of fur seals and sea lions, and the sea here usually is curling in shoal breakers or sputtered with tide rips. It is a small rocky islet, much less than a quarter of a mile in length; upon it, in 1874, the seals bred. It was the place where they havled out first in the season as holluschickie, and were the earlicst arrivals usually of the season, being found there sometimes as early as the middle of April.

A survey of it to-day shows that the sea lions have totally abandoned it and while the seals have taken possession of it as a breeding ground, upon it we find about 2,800 cows, about 75 bulls, about 2,500 holluschickie, and about a dozen polsecatchic. These brecding seals, while not massed, have distributed themselves over the rock proper, often to the highest ground, upon which the sea lions once laid; the latter have been persistently driven off by the natives since 1890, who came over to drive and kill the holluschickie in turn. The sea-lion feature of this rock has entirely disappeared; there are none here. This breeding ground has been firmly established by the seals, which have sought refuge here from the incessant hustling and driving to which they have been subjected on the Reef rookery margins by the natives during the past 15 or 20 years. In the course of time, when the Reef regains its former shape and numbers, history will repeat itself, and many of these brecding seals return to their original habitat; and the sea lions also, if they are not disturbed.

This closes the survey of the Reef and Garboteh rookeries.

To recapitulate.-Grand sum total for Reef and Garbotch, 393 bulls, 15,000 cows, 13,500 pups; Seevitchie Kammen, 75 bulls, 2,800 cows, 2,520 pups; total, 468 bulls, 17,800 cows, 16,020 pups. I agoon, 8 bulls, 250 cows, 230 pups.

whole field from the summit of Fox Hill, the interior of it was fairly green, and only straggling bands of a dozen seals here and a hundred there were hauling over it.

"Eighteen years ago these slopes of Garbotch and the Reef P'arade were covered with angry. eager, lusty bulls, two and three weeks before the first one of the cows arrived. They came in by the 5-22 May in such numbers as to fill that space at close intervals of 7 to 10 feet apart solidly from the shore line to the ridge summit and over even so far that it reguired the use of a club vigoronsly, before we conli get upon old summit and over even so far that it required the use of a ching in every clirection under our eyes.

"This season I do not observe a bull here where 1 saw at least 10 at this time 18 years ago. Now, not a fight in progress; there are not bulls enough to quarrel. They are llow scattered apart so willely over this sanie ground as to be 100 and even 150 feet apart over ground where in 1572 an interval of 10 feet over this sanie ground as to by
between them did not exist."

$1181.4-13-5$ 
Lagoon rookery (July 12, 1913).-To this we add the statement that Lagoon rookery, right across the Village Cove, and between the lagoon and the saa, has practically disappeared. There were only two harems full, and three ragged ones, or 8 bulls and 250 cows on its entire extent, July 12, 1913. No young male seals in sight in the rear or on the surf margin, and its condition "just as it was last year," according to the natives.

On Reef and Garbotch rookeries. - Season of 1890 there were 4,500 bulls, 225,000 cows, 203,000 pups; season of 1874 there were 13,000 bulls, 484,000 cows, 435,000 pups.

On Lagoon rookery.- Season of 1890 there were 100 bulls, 4,500 cows, 4,000 pups; season of 1874 there were 580 bulls, 18,000 cows, 16,250 pups.

\section{CENSUS OF IAGOON ROOKERY.}

[Field notes to accompany the chart and survey of conditions of Lagoon rookery, St. Paul lsland, Pribilov group, Saturday, July 12, 1913, by llenry W. Elliott and A. F. Gallagher, special agents, House Committee on Expenditures in the Department of Commerce.]

(The condition of the rookery, when comparison is made with that of 1890 , is founded upon the published and official survey made by Henry W. Elliott and Charles J. Goff, July 10, 1890, and duly published as House Document 175, Fifty-fourth Congress, first sescion. pages $31,32,33$.

We find that the area occupied in 1890 has been diminished to a fringe of seven harems just above the surf wash with $\&$ bulls and about $250 \mathrm{cows}$. There are no polsecatchie in the rear, or visible in the sea, and no idle bulls as we start in, not one in sight to the finish of our survey.

This enumeration of $\&$ bulls to 250 cows is very misleadire as to the actual service rendered, and indeed for that matter the relation of these bulls to the cows is very hard to express in general figures like the above.

Here in fact are only four harems-one has over 100 cows, another 80 cows, the third 60 cows, and the fourth has 8 cows, with 2 bulls each having only $1 \mathrm{cow}$.

There are only 6 bulls out of the 8 , with any show of service demanded, yet in fact three of those old bulls are simply overworked, and the service which should be distributed is not so made. This average of service rendered is about the same all over the rookeries to-day, and is entirely out of the normal and proper distribution of it as it was in 1874 , and should be now.

To recapitulate.-For Lagoon rookery, July 12, 1913, we find 8 bulls, 250 cows, 250 pups. Season of 1890,100 bulls, 4,500 cows, 4,200 pups; season of 1874580 hulls, 18,000 cows, 17,250 pups. 


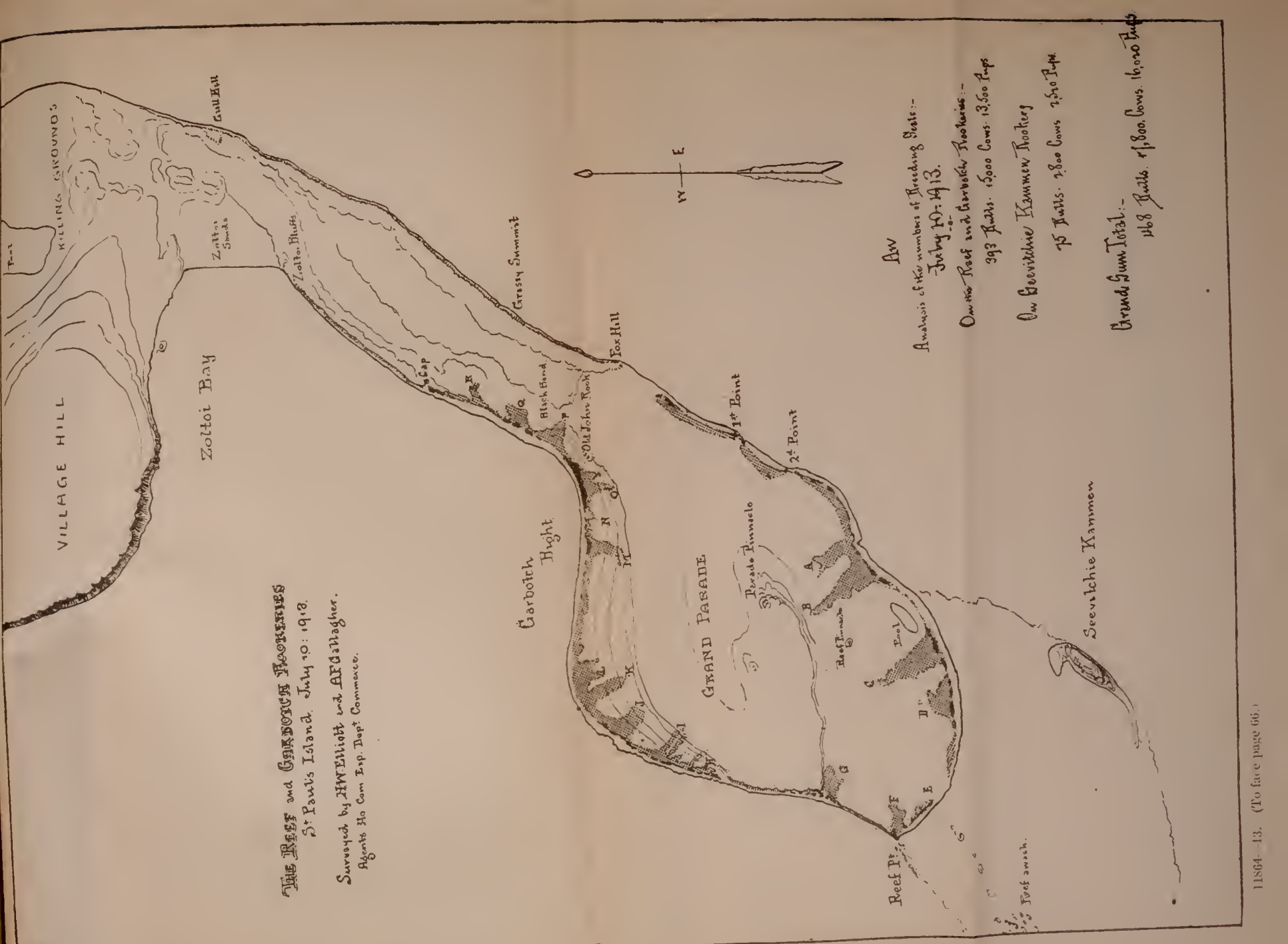




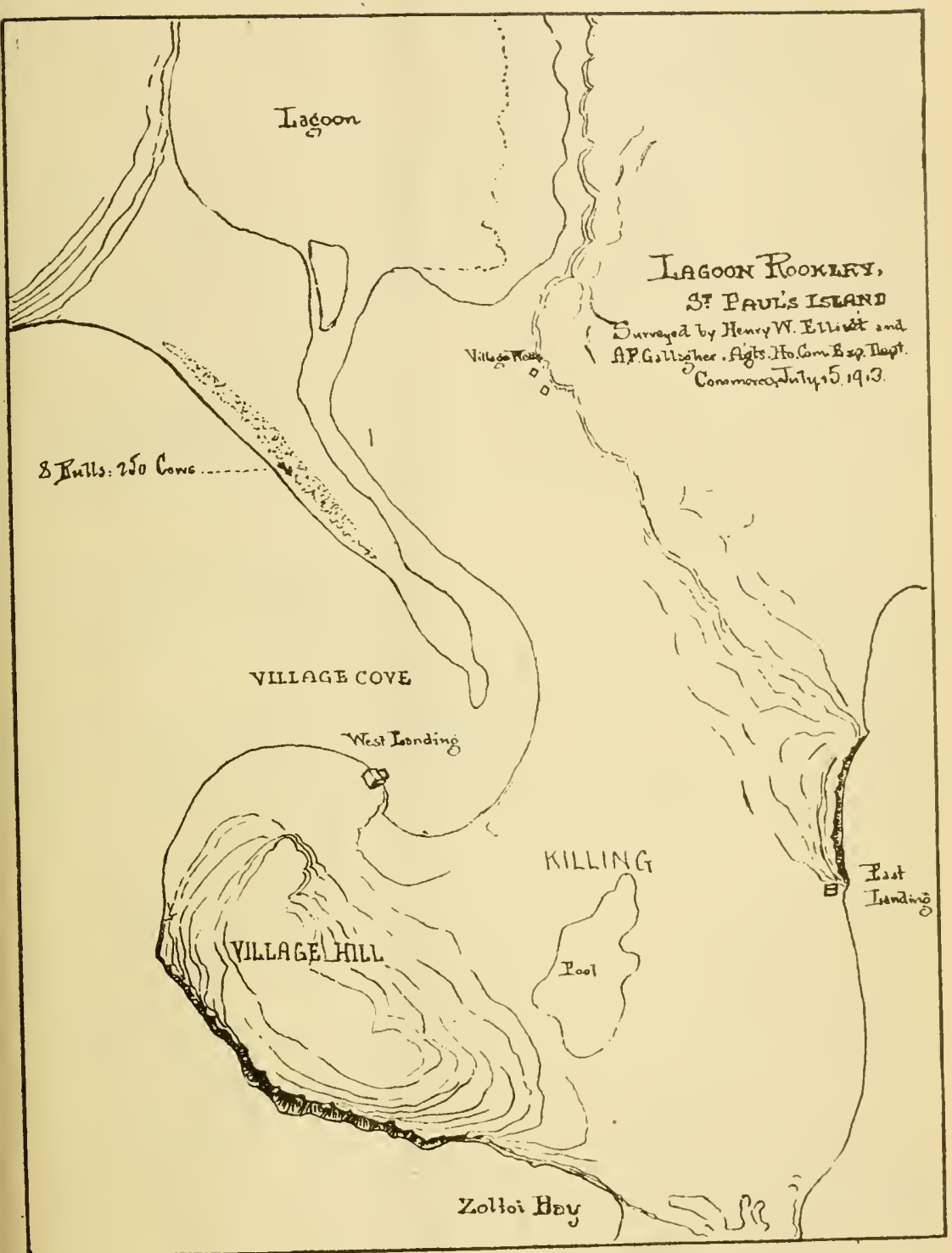




\section{PART 3.}

Charts of census of firr-seal herd, July 10-20, 1913, by Elliott and Gallagher, speeial agents House Committee on Expenditures in the Department of Commerce.

\section{CENSUS OF TIE NORTII ROOKERY.}

[Field notes to accompany the chart and survey of condition of North Rookery, St. George lsiand, Fribi lov group, July 18, 1913, by llenry W. Elliott and A. F. Gallagher, special agents House Committee on Expenditures in the Department of Commerce.]

(The condition of the rooksy, when comparison is made with that of 1890 , is founded upon the published official survey marle by Henry W. Elliott, July 10,1890 , and duly published as IIouse Document No. 175, 54th (Congress, first session, pages 51, 53, and 54.)

We begin our survey of this rookery by taking up the chart of 1890 , at station L, under which no sign of the 1890 cliff belt of breeding seals is in evidence to-day; nor is thers any evidence of the hauling of any seals in the "ravine" which we found so well indicated on the chart of 1890 .

From this we proceed to station $K$, and between station $L$ and station $K$ and right on the point under station $K$ we find 11 active bulls and about 400 cows, with 2 idle bulls. Proceeding from station $\mathrm{K}$ to station. $\mathrm{J}$, we find an irregular series of scattered harems; consisting of a total of 16 hulls and about 610 cows; no young males in sight, or idle bulls.

We proceed from station. J to station I, and within the lines of the 1890 survey we find 7 bulls and about 149 cows. From station I to station $\mathrm{H}$ is the finest massing on this rookery, and we estimate therein 30 bulls and about 3,500 cows: still we see no "idle" bulls or "polsecatchie" on or around this section.

From station $\mathrm{H}$ we proceed to station $\mathrm{G}$, and between those two stations we find a "pod" of lolluschickie containing about 400 to 450 , consisting chiefly of yearlings, with, say, 50 2-year-olds, a few 3 -year olds, and three or four 6-year-old bulls, and as many "polsecatchie" or 5-year-olds. At the extreme point $(G)$ we find two bulls and two harems containing about 36 cows.

From station $\mathrm{G}$ we go to station $\mathrm{F}$ and find 6 bulls and about 250 (ows, all at the surf margin between; no idle or young bulls.

Now proceeding from station $F$ to station $E$ we find 18 bulls and about 1,200 cows; no idle or young bulls.

From station E to station D we observe about 20 bulls and about 550 cows, with one 7 or $\$$ year old idle bull, but no "polsecatchie."

From station D to station $\mathrm{C}$ we find nothing, it being an aloandoned bluff. From station C to station B we find nothing, and from B to A every restige of the life of the 1890 survey is eliminated.

At station A, looking back, we have this to say: The North Rookery presents the appearance, as compared with 1890 , of a complete elimination of the surplus breeding male life, the young 6-year-old bulls, the "polsecatchie," and the holluschickie, that swarmed on this ground in 1874 and in 1890 were relatively there. ${ }^{1}$

1 As this is the chief rookery of St. George and one which has had perluaps more attention paid to it than all of the others, on account of its being so close to the village, the following notes made of it in 1 s90 contrasting its condition with that of 1874 are timsly (p. 5t, 11. 1) 03. 175, 54th Cong, Ist sess):

"I came upon this breeding ground to-day, July 19, 1sin, after an absence of just $16 \mathrm{years}$. 1 find the topography unchanged, the hauling grounds all grass grown, together with the usual flowering plants which seem to follow (on all of these declining rookeries) the abandonment of hitherto polished rock and hard-swept soil traveled over and laid upon by the seals. The breeding animals on the several areas of this 


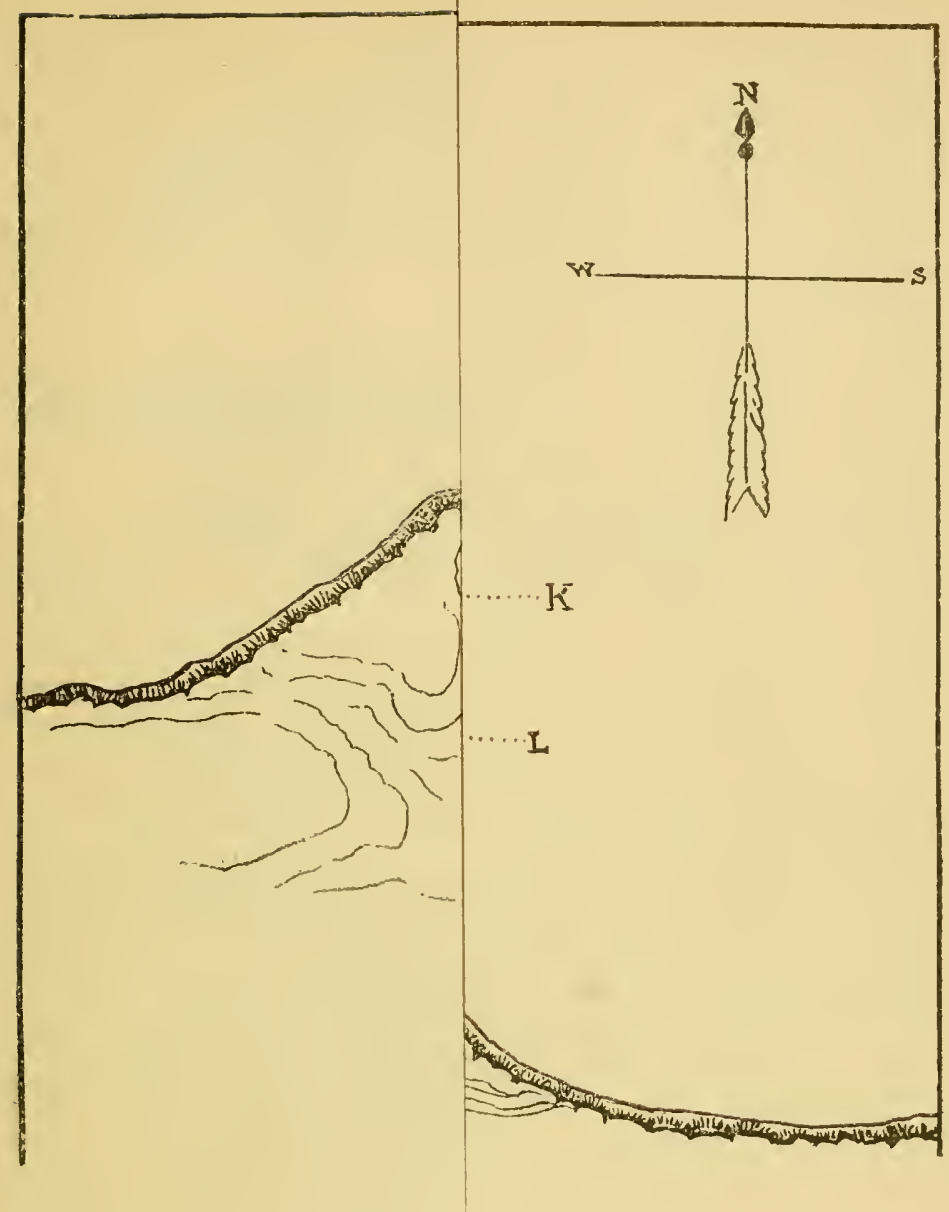

11864-13. (To face page 68.) 


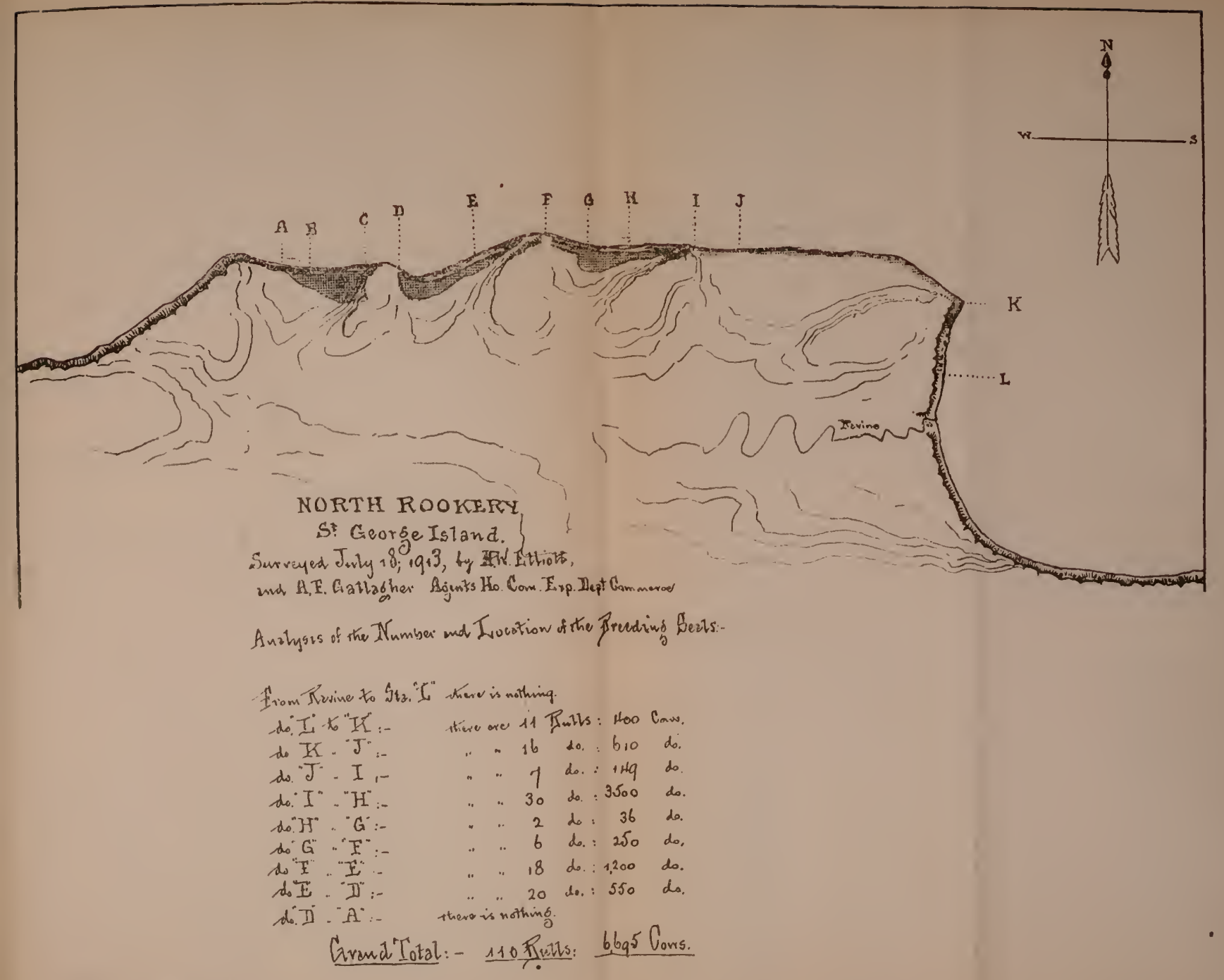


This rookery in 1890 suflered a loss of only about one-half from the survey of 1874 . The survey made to-day shows a loss of nearly five-sixths of its breeding strength since 1874 , and it has dwindled to the following figures in totals for 1913, to-wit:

To recapitulate.-For the North Rookery, July 18, 1913, we find 110 bulls, 6,695 cows, 6,200 pups; season of 1890,485 bulls, 19,000 cows, 18,000 pups ; season of $1874,2,302$ bulls, 38,500 cows, and 35,000 pups.

\section{CENSUS OF IITTLE AND GREAT EASTERN ROOKERY.}

[Field notes to aecompany the charts and surveys of condition of Great Eastern Rookery and Little Eastern Rookery, St. George Island, Pribilof Group, Friday, July 18, 1913, by Henry W. Elliott and A. F. Gallagher, special agents House Committee on Expeaditures in the Department of Commerce.]

(The condition of the rookery when comparison is made with that of 1890 is founded upon the published official survey made by Henry W. Elliott, July 10, 1890, and duly published as House Document No. 175, Fifty-fourth Congress, first session, pp. 51, 52, and 56.)

We begin this morning a survey of the rookeries of St. George Island, at the extreme eastern end of the cliff belts of the Great Eastern Rookery, starting at station E, from which we proceed westward to station $\mathrm{G}$, where we find 11 bulls and about 200 cows, plus 11 bulls and about 200 cows, irregularly spread on the beach belt of rocks under the cliffs. This is all the life that now survives there from the 1890 survey.

On the rookery ground from station $\mathrm{G}$ to station $\mathrm{F}$ we find 7.5 bulls. These bulls lie under the base of the cliff, beginning at station $G$, two harems deep, but they do not rise on the hill. They are dispersed over the ground here more evenly than on any rookery we have looked upon thus far. It is safe to say the average harem will hold as good as they did on St. Paul Island. Forty and fifty and sixty cows to the bull is not an excessive estimate. We find here a total of about 75 bulls and about 2,700 to 3,000 cows. They are lying just above the surf wash on the cliff belts and do not rise on the hill at station G. We see no "polsecatchie"; we see no "idle bulls."

Between stations $\mathrm{G}$ and $\mathrm{F}$, as in 1890 , we observe about 25 sea lions, included among them being four or five big bulls. As we go down, a pod of holluschickie are alternately sleeping and playing between the pool and the outer edge of the breeding seals that we have just enumerated. We see here, between the holluschickie and the breeding seals, two young 6-year-old bulls, being the only idle or separate male breeders in sight at this rookery. Between the pool and the foot of the breeding seals that we have just enumerated, we find this pod of holluschickie numbering at least 2,500 to 3,000. It is composed chiefly of yearlings; with about one-quarter 2 -year-olds, and

rookery are in the usual poor form and characteristic of those wbich I have described on St. Paul-the same scanty supply of old bulls; no young bulls on the rookery or outside on the water's edge; large seattered harems and every evidence of imperfect serviee. In all of these forms precisely as they are over on St. Paul.

"Yet this, the chief rookery of St. George, which held 76,250 breeding animals and their young in 1874 , has suffered a loss of only one-half of its cows and pups-but the bulls, fully five-sevenths of them are missing. This rookery was the largest on St. George in Is74. It has been so ever siuee and is to-day; but, large as it was, tbere was only one on St. Paul sinaller in 1874, the Lagoon Rookery (Nahspeel we can not count). However, to-da there is still another one smaller, and that is Keetavie, though it was twiee as large as this North Rookery in 1874 . It is an admirable point of seal ground, well lrained and free from muddy pools during rain storms. It is in full sight of the village and only one short half inile's walk away.' 
a few 3-year-olds added to these; but the great bulk of yearlings, with two or three 6 or 7 year old bulls, and four or five 6-year-old bulls and rough 5-year-olds, making the exhibit which we have just estimated.

We find from station $\mathrm{F}$ to station $\mathrm{X}$ that the life of 1890 has completely disappeared; not a harem or an idle bull, or any vestige of that life remaining. From station $\mathrm{X}$ we proceed over the circuit of the survey of 1890 ending at station $\Lambda$. Passing along here we find three harems, with about 25 cows only. We also find here one big bull sea lion.

We now proceed from this station to the finish at station $A$, where a thin fringe of the life of 1890 is represented by 6 bulls and about 130 cows, chiefly massed around one bull. We also find here, just be-

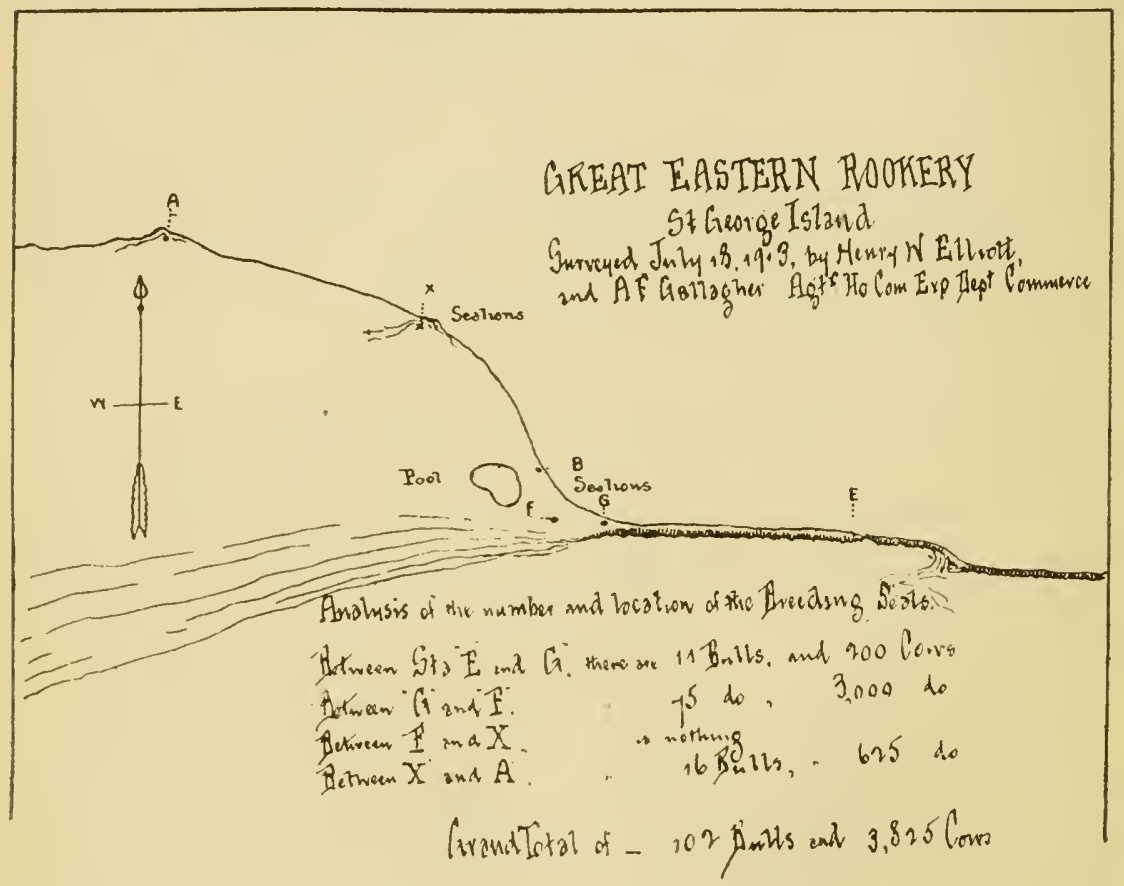

yond, two additional bulls and about 150 cows, one of the bulls being an idle 6-year-old bull, again beyond. There are no polsecatchie in sight, and no other idle bulls.

We now proceed to the finish at station $A$, and we find there, directly on it, some 320 cows, chiefly massed around 4 bulls, one being a 6-year-old; no polsecatchie; no idle bulls; no sign of other 6-year-olds, or any other males in sight.

This closes our review of the Great Eastern Rookery; from this point we proceed to take up the 1890 survey of the Little East Rookery. We find from station B to station A of the 1890 survey a total elimination of all life, save two harems-one of about 25 cows and the other of 3 or 4 ; no polsecatchie in the sea nor at the rear; no idle bulls; no holluschickie on the ground; but grass and 
vegetation completely cover the hauling grounds of 1874 , so much so that the pool is being actually sodded over. ${ }^{1}$

To recapitulate.-For Great Eastern Rookery, July 18, 1913, we find 102 bulls and 3,825 cows, 3,500 pups. For Little East, 2 bulls, 30 cows, 27 pups. Season of 1890, Great Eastern had 112 bulls, 4,500 cows, 4,300 pups; season of 1S74, Great Eastern had 714

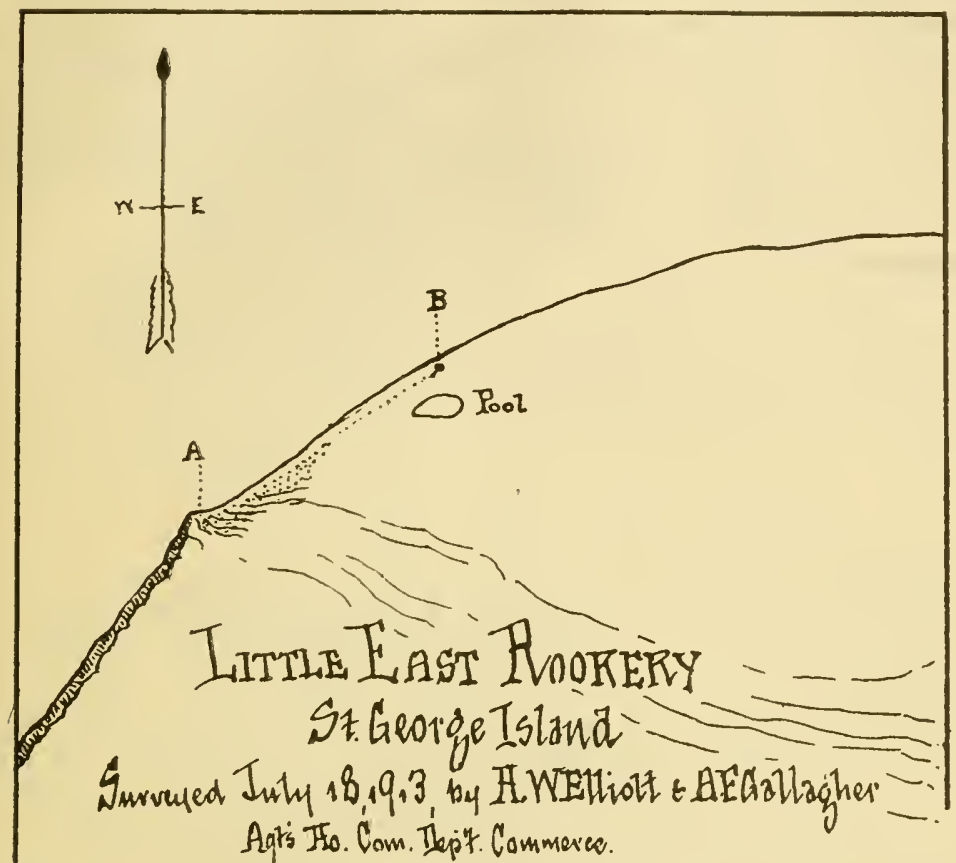

indysis of the Numbers and Location of the Arceating Geats.

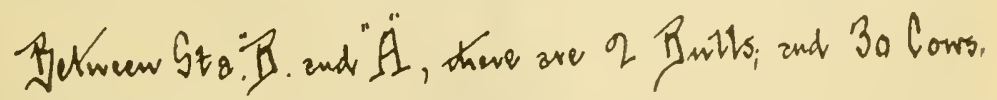

bulls, 3,000 cows, 12,500 pups; season of 1890, Little Eastern had 62 bulls, 2,500 cows, 2,300 pups; season of 1874 , Little Eastern had 112 bulls, 6,000 cows, 5,450 pups.

1 With regard for the condition and appearance of the Great Eastern Rookery in 1590: On page 56, House Document 175, Fifty-fourth Congress, first session, is the following offieial description of it under date of July 20, t890:

"In $1873-74$ this breeding ground ranked third in the list of five that were found on the Island of St. George. To-day it seems to have been the heaviest loser. It has literally dropped down to a mere skeleton of its form in my early survey (18:3). That extended rocky flat here from which the rookery ground proper gently rises on the hill slope was one of the most attractive hauling gronnds for the holluschickie on St. George 16 years ago; now its entire surface is covered with a most luxuriant turf: it looks like a Kentucky hlue-grass meadow.

"I think that this rookery presents the most perfect illustration and eloquent, too, of that ruin and demoralization wronght by the present order of scraping the breeding lines on all of the rookeries in getting the daily drives of killable seals. It presents itself so in this plain manuer.

"In 1873 there was only 900 feet of rookery sea margin here; 200 feet of this total was a solid massing of the breeding seals up the hillside from the sea, as shown by the $18 \pi t$ tint upon the acrompanying map. It was 200 feet deep and contained 20,000 of the 25,000 seals, all told, that then existed at this point. To-day there is 3,275 feet of rookery sea margin here; a straggling ragged belt, not even a full harem's width or depth, except under that side-hill expansion between $\mathbf{F}$ and $\mathrm{G}$, where there is, instead of the 200 feet of massing citer above only 30 feet of arerage depth. This driving by the lessees repeated day after day has created that long extension of over 3.000 feet to the spa margin of 1874 , on this rookery, while the seals themselves are barely one-third the number they were at first record." 


\section{CENSUS OF ZAPADNIE ROOKERY.}

[Field notes to accompany the chart and survey of condition of Zapadnie rookery, St. George Island Pribilov group, July 18, 1913, by Henry W. Elliott and $\mathrm{X}$. F. Gallagher, special agents House Com-

(The condition of the rookery when comparison is made with that of 1890 is founded upon the published official survey made by

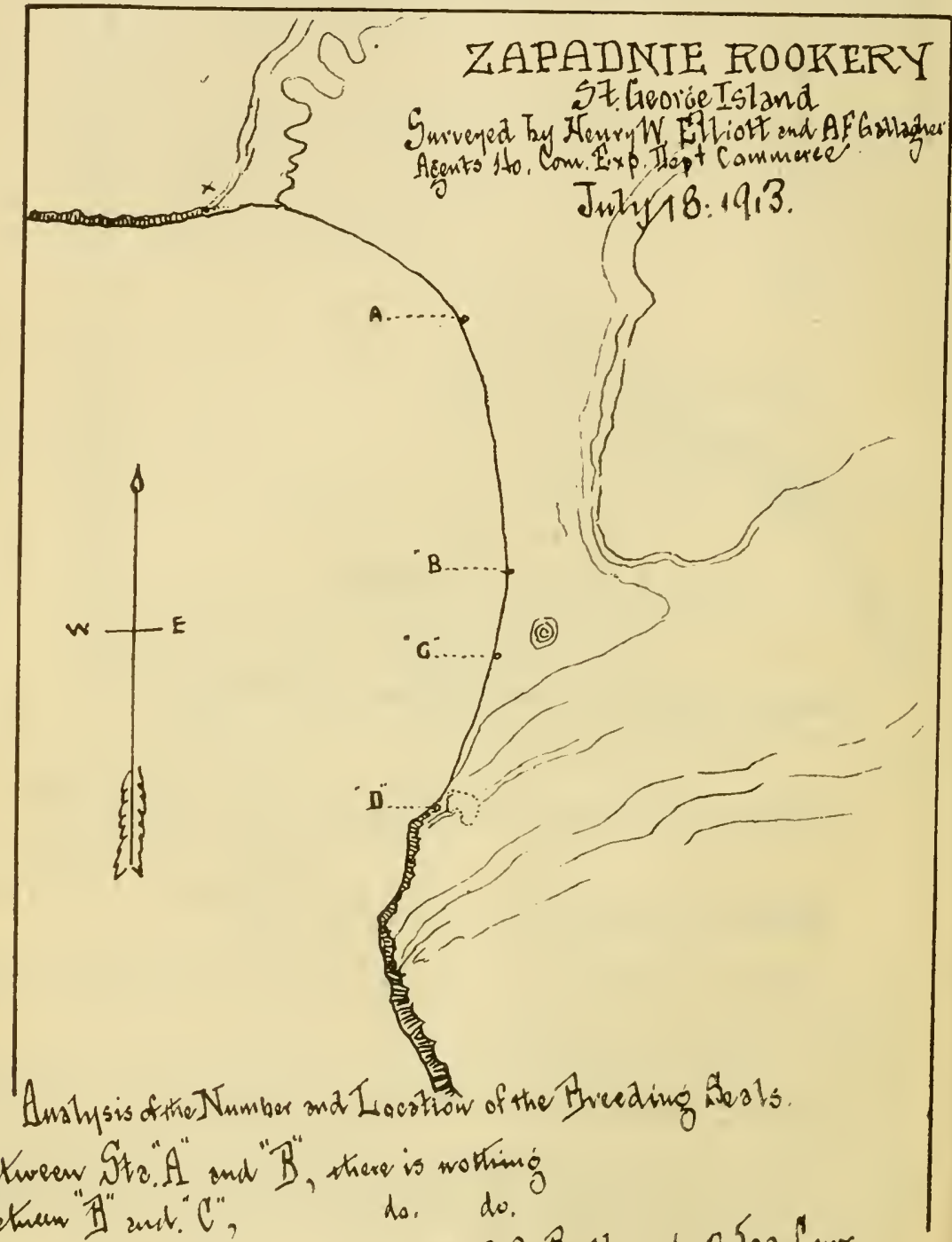

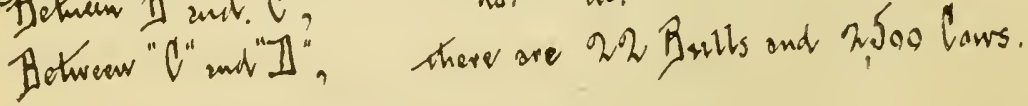

Henry W. Elliott, July 10, 1890, and duly published in House Document No. 175, Fifty-fourth Congress, first session, pp. 31, 32, 
We approach this rookery from station A of the 1890 surver, and we find that to station B every vestige of the fur-seal herd then existing in 1890 has entirely disappeared. ${ }^{1}$

There is not a single pod of holluschickie on these grounds. From station B to station C, where a large hauling of holluschickie was made in 1890, and thence ranging up the hillside there is not a single holluschak upon it to-day.

We find from station C to station D a remnant of the hillside rookery only, consisting of some 2,500 cows and 22 bulls, with only one idle bull in sight-not a single young 6-year-old or 5-year-old bull in the water or on the land behind the rookery. This is the most significant, complete dearth of all surplus male breeding life that we have yet met on this survey. The estimate of 2,500 cows is not excessive, but is very fair. They are bunched together practically, immediately at the foot of the bluffs, at station D, and are semimassed part way up the hill, half way to station D.

This completes the survey of the rookeries on St. George Island.

To recapitulate. - For Zapadnie rookery, July 18, 1913, we find 22 bulls, 2,500 cows, 2,250 pups. Season of 1890 there were 150 bulls, 6,000 cows, 5,500 pups; season of 1874 there were 559 bulls, 9,000 cows, 8,250 pups.

\section{CENSUS OF STARRY IRTEEL, ROOKLRY.}

[Field notes to accompany chart and survey of conditions of Starry Irleel rookery, St. Geotge Island, Pribilof group, July 1S, 1913, by Henry W. Elliott and A. F. Gallagher special agents House Committee on Expenditures in the Depariment of Commerce.]

(The condition of the rookery when comparison is made with that of 1590 , is founded upon the published official survey mate by Henry W. Elliott, July 10, 1890, and duly published as H. Doc. No. 175,54 th Cong., 1st sess., pp. 51, 52, and 53.)

As we approach the sea foot of this rookery, we find a pod of at least 3,000 holluschickie [and on the surf-washed point of Starry Arteol, 400 or 500 more, mostly yearlings]. We find here one solid rookery mass; it is the most perfect of its kind to-day on these ronkeries; from the foot of Starry Arteel Hill (of the 1890 survey), it rests on the same lines of 1890 , but still within the outer lines half way back between station $G$ and station $O$. On that area there are about 80 bulls with harems massing in the aggregil te at least 4,500 cows. The most encouraging sign seen here is the alvanced movement of two young bulls with a cow each, lying just 10 or 15 feet outsile of this massed rookery margin; thus they are leading the way for the overflow next year, which most likely will come to that line. As with

1 The complete disappearance of Zapadnie (St. fieorge) rookery from its chief loeation and numbers here in 1873 is clearly exposed by this survey of 1913, as given above; and that makes the following deseription of the same as it was in 1873 of interest (p. 49, H. Doc. No. 175,54 Cong., 1st sess.):

"Zapadnie rookery (1\$73-74: its condition and appearance July, 1474)): Directly across the island (St. George) from its north shore to Zapadnie Bay, a little over 5 miles from the village, is a point where the southern bluff walls of the island turn nor th and drop quickly down from their lofty elevation in a suecession of heary terraces to an expanse of rocky flat bordered by a sea sand beach. Just between that sand beach and these terraces, howerer, is a stretch of some 2,000 feet of low, rocky shingle, which borders the flat country back of it, and upon which the surf breaks free and boldly. Midway between the two points (i. e., bluffs and sand beach) is the rookery, and a small detachment of it rests on the direct slope of the bluff itself to the southward, while in and around the rookery, falling back to some distance, the holluschickie are found."

This complete elimination of Zapadnje rookery July 1s, 1913, from its main location between stations $A$ and $B$, where it had been so well located, to that patch on the bluff as found in 1913 is heightened as to danger by the spectacle presented of some 2,500 cows there now with only 22 bulls to serve them and not a young male seal in sight anywhere. 
the other rookeries, barring this exception here, we see the same complete absence of young, virile male life. There is nothing of the kind in view. Had there been the usual proportion, a hundred of these young bulls would be lying outside, all accompanied by a few cows, in every direction along the entire outer line of this fine ronkery massing-leading the way for the overflow next year. It is believed by us, however, now, that by letting these creatures alone, as it is proposed to do and as the law directs, within four years this massing

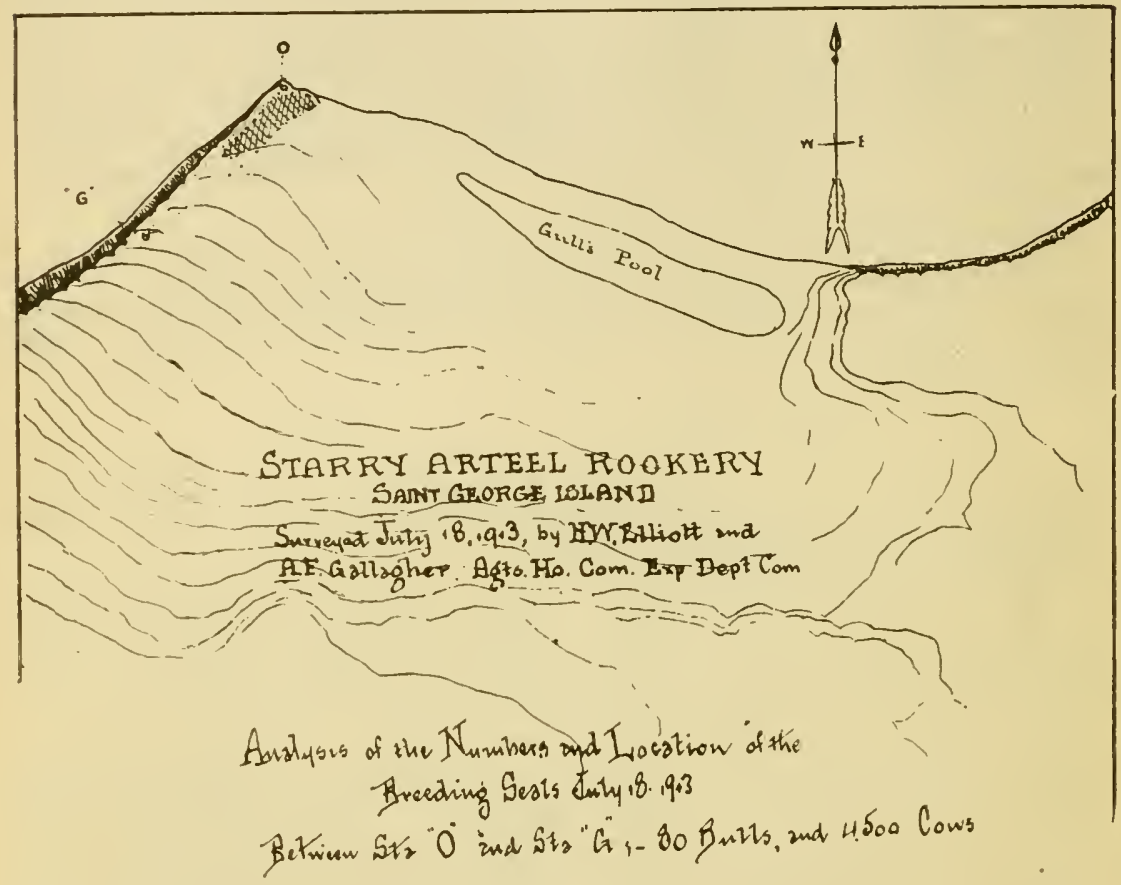

will have overflowed the boundaries of to-day, and will have reached those of 1890 . This is the only rookery where this solid massing and steady advance from that massing ont, is in actual evidence, and will be an interesting study to observe its increase during the next four years. It is in fine shape to-day for making an accurate comparison with what it shall increase up to within the next four or five years.

To recapitulate: For Starry Arteel rookery, ${ }^{1}$.July 18, 1913, we find So bulls, 4,500 cows, 4,200 pups. Season of 1 S90 there were 220 bulls, $\$, 000$ cows, 7,500 pups; season of $1874,{ }^{2} 975$ bulls, 15,250 enws, 14,250 pups.

1 This is the place, just to the eastward of Gulls Pool, and on those low slopes of the blufls which rise there from the sea, where Pribilof pitched his first camp on this island after he discovered it in June, 1786. "Starry Arteel," or "Old Settlement."

2 Starry Arteel as it was in 1874 (p. 51, H. Doc. No. 175, 54th Cong., 1st sess.):

"This rookery is the next in order and it is the most remarkable one on St. George Island, lying as it does in a bold sweep from the sea up a steeply inclined slope to a point where the bluffs bordering it sea ward are over 400 feet high, the seals being just as closely crowded at the summit of this lofty breeding plat as they ale at the water's edge. The whole oblong oval on the side hill is covered by their thickly crowded forms. It is a strange sight, also, to sail under these bluffs with a boat in fair weather for a landing, and as you walk the beach over which the cliff wall frowns a sheer 500 feet there, directly over your head, the craning necks and twisting forms of the restless seals ever and anon as you glance upward appear as if ready to launch out and fall below, so closely and boldiy do they press to the very edge of the precipice." 
EXHIBIT B.

[The "Carlisle rules" of 1896. Same as "Hitchcock rules" of 1904.]

Specific details of the violation of the "Carlisle rules," ordered May 14,1896, which prohibit the killing of "yearlings, and seals having skins weighing less than 6 pounds."

Said rules published on the islands and officially recorded June 17, 1896.

Said rules were suppressed and withheld from the knowledge of the House Committee on Expenditures in the Department of Commeree and Labor from May 31, 1911, to July 30, 1913, by the United States Bureau of Fisheries.

Said rules were never canceled or amended from 1896 to 1904 by any authority of record and legal. The Hitchcock rules of May 1, 1904 , were the same in effect, and were issued by the Secretary of Commerce and Labor, then in ignorance of the fact that the Carlisle rules were actually in effect, but ignored by the United States agents and the officialism in charge of the islands and by the lessees.

\section{THE CARLISLE RUI.ES.}

The regulations of the United States Traesury Department, dated May 14, 1896, ordered the agents of its Government to prevent the killing of "yearlings and seals whose skins weigh less than 6 pounds."

These regulations were violated on the islands that year by those agents of the Government who permitted the lessees to kill more than $\$, 000$ young seals whose skins weighed less than 6 pounds, Dr. David Starr Jordan having taken charge of this killing as the "chief" of the American membership of the Jordan "Joint Anglo American Commission," ignored these regulations and falsified the record of this illegal killing in his "preliminary report of November 7, 1896," "Treasury Document No. 1913," p. 21. (See Hearing No. 14, pp. $950-951$, postea.)

The following order of the United States Treasury Department was published on the seal islands June 17, 1896 (see p. 14, United States chief special agent's journal, St. Paul, Island Alaska, under date of June 17, 1896), to wit:

On page 14 (Official record of journal of the chief special agent in charge of the seal islands), this letter is entered by J. B. Crowley. United States special agent, on page 14 (of the "journal" of this office), under date of "Tuesday, June 17, 1896," and before the killing was begun, to wit:

Treasury Departuent, Gffice of the Secretary, Washington, L. C., Uay 1.4, 1Swi.

Mr. J. B. C'rowley,

Special Agent in Charge of the Seal Islunds,

Care North Amerian Commercial Co.,

San Francisco, Cal.

SIR: I inclose herewith for your information copy of a letter dated the 13 th instant, addressed by me to the Secretary of the Treasury and approved by him, in relation to the taking of fur seals on the Pribilof Islands and determining the quota of such seals to be allowed the North American Commercial Co. during the season of 1896 . You are instructed to permit said company to take on the islands during the season of 1896 all 
killable male seals over and above the number which, in your opinion, is sufficient to fertilize the female seals, the number taken not to exceed in any event 30,000 seals. The killing of yearlings and seals whose skins weigh less than six pounds is prohibited. Respectfully, youro,

'True copy:

C. S. HAMLIN, Acting Secretary.

Attest:

Henty W. Elliott.

A. F. Gallagher.

THE PROOF OF VIOLATION OF THE PUBLISHED REGULATIONS OF THE SECRETARY OF THE TREASURY, BY ITS LESSEES, IN KILLING YEARLING SEALS AND "SEALS HAVING SKINS WEIGHING LESS THAN 6 POUNDS," DATED MAY 14, 1896; SAID REGULATIONS BEING CAREFULLY SUPPRESSED TO THE COMMITEE BY THE OFFICIALS OF THE BUREAU OF FISIIERIES FIROM MAY 31, 1911, TO JULY 30, 1912. ${ }^{\perp}$

The records which show this violation of the department rules and regulations of May 14, 1896, by the lessees up to date of expiration of their lease May 1, 1910, are:

I. Full details of this violation are found in the London sales atalogues of Messis. C. M. Lampson Sons, for November-Deeember, 5896 to 1909 , and by the daily entries made of the killing this season of 1896 , and thereafter in the official journal of the United States Treasury agent in charge of the seal islands at St. Pauls village. (See poster.)

II. The fact that these rules prohibiting the kiling of "yearlings" and seals having sknis weighing less than 6 pounds has been successfully suppressed and concealed by the lessees and their associates, the agents of the Government, is clear when it is known that the Hitcheock rules of May 1, 1904, were issued because it was not known then, to their author that they had been published in 1896, on the islands, and were never cancelled by the department.

On the 27th of July, 1912, Mr. H. W. Eliott testified to the committee as follows (Hearing No. 14, pp. 950, 951):

Dr. D. S. Jordan, with the full cooperation of the Treasury Department in 1896-97, and Commerce and Labor up to 1912 , is responsible for the killing of female seals for their shins by the lessees of the seal islands of $A$ laska. He went up to these islands in 1896 and 1897 and was empowered by the Secretary of the Treasury to fix the number of seals that might be killed for their skins in those seasons, respectively,

1 COMMITTEE ON EXPENDITUPES IN THE

DEPARTMENT OF COMMERCE AND LABOR House OF REPRESENTATIVES Friday, A pril 19, 1912.

The committee met at 10.30 o'clock a. m., Hon. John H. Rothermel (chairman) presiding.

Present: Representatives McDermott, Young, McGuire, and Patton.

TESTIMONY OF BARTON W. EVERHANN.

The witness was sworn by the chairman.

The Cindran. Doctor, you may state your othicial position.

Dr. FverMANN. My official position is assistant in charge of the Alaska fisheries service, in the Bureau of

Fisheries, Department of Commerce and Labor.

The Cinarian. Now, if you desire, you may proceed to submit whatever facts you have for the consideration of the committee.

Dr. EvERMANN. The second charge is that at least $12 \$, 47 \mathrm{~s}$ yearling male seals were killed by the lessee from 1890 to 1909 , both inclusive, contrary to law and the regulations.

In answer to this charge it should be sufficient to say that the law has never made it illegal to kill yearling male seals; nor has it ever been contrary to the regulations to kill yearling male seals, except in the seasons of 1904 and 1905 , as is shown by the regulations for the various years to which 1 have called your attention. Therefore, even if 128,478 yearling male seals have been killed since 1599 (which is not admit ted) they could not have been killed illegally, because there was no law against killing yearling male seals, and there has been no regulation against $k$ lling yearling male seals except in 1904 to 1909. 
and to extend the limit of driving said seals to any time in the said seasurs he saw fit.

In 1896 Dr. Jordan reports (Nov. 7, p. 21, Treasury Doenment No. 1913) "30,000 killable seals were taken, 22,000 of these, to the best of our information, being 3 -yearolds."

Not quite 7,500 of that 30,000 were 3 -year-eld skirs; 8,000 of them were $4 \frac{1}{3}$ to 5 pound skins or yearlings or "eye plaster" skins_-1

The driving in 1896 was proseented with vigor up to the 28 th of $\mathrm{July}$. It was impossible to drive those seals after the 17th of July, as they were found on the islards without driving, adult females and yearlings, males and females, commingled, and it was equally impossible to separate the sexes on the killing grounds before killing them, so a large number of this forl,idden class of seals were so killed and their skins sold in London as 2 and 1 year-old males.

Again. in 1897, Dr. Jordan reports (Nov. 1, p. 18, Treasury Document No. 1994): "* * * The quota of the year $(20,890)$ is made np practically of 3 -year-old bachelors. Some 2-year-olds are killed and some 4-year-olds, but the majority taken are 3-year-olds."

Not quite 7,000 of the 20,890 were 3 -year-olds, and in spite of the most desperate driving, kept up to the 7 th of August on St. Paul, and the 11th of August on St. Ceorge Island.

The Chatrman. What is the signifieance of that? I ask beeause you seem to place so much emplasis upon it.

Mr. Elliott. That is beeause the "official" killing season is elosed on the "1st of Argust." Have youn not heard them say that the "season closed on the lst of Angtist"?

The Charrman. What is the harm in lilling until the 7th of August?

Mr. EцLiotr. Because after July 20, annually, you are driving yearlings, and you can not separate the males from the females in that elass. That is the reason why they should rot kill after the 1st of Augtst, and they "officially" say they do not kill. It was impossible for the lessees to have so driven and failed to have killed adult female mother seals in any one and all of these drives after the 17th of Jily. They were killed and their skins sold in London as 6-pound or 2-year-old male skins.

They were doing it under my eyes. I saw them doing it, and I stopped them. The lessees refused to take the yearling or "eye-plaster" skins this year, beeatise the price for them in 1896 barely paid expenses. Otherwise the yearling, $4 \frac{1}{2}$ to 5 pound skins. would have been taken.

Here we have the official declaration of Dr. Jordan that no yearlings and females were killed in 1896 and 1897 , when the killing was all done under his eyes and control.

No Lembkey there, no Bowers there, but Dr. Jordan, the "great naturalist," was there. "branding" seal pups to put the pelagic hunters out of business, and not putting an exd to this illegal businese on the islands. [Reading:]

"The London sale catalogues of 1896 and 1897 indict and convict Dr. Jordan of making a wholly erroneous and improper report to the Government. It is charitable to assume that he was ignorant of the facts, and clid not realize the gravity of his error or its far-reaching and injurions effect.

"Therefore this initial responsibility of naturalists with regard to the matter of driving and killing of yearling male and female seals on the seal islands of Alaska, and as permitted by the Treasury Department and Department of Commerce and Labor since 1896, is authoritatively summerl up as follows:

"July 20,1890. Elliott stopped the work of the lessees on the seal islands to-day; he did so because they were killing mother seals along with 2-year-old males for" their skins; they had been doing so since the 17th of July: the lessees claimed that they had not intentionally violated the law, since it was impossible to distinguisli the adult females from the 2-year-old male seals in the 'pods' when elubberl; it becams' imperative to stop the work, therefore, on their own arImission.

"November 19, 1890. Elliott describes in his report on page 86 (H. Dor. No. 175 , 54th Cong., 1st sess.) with detail the manner in which the seal drives after July 17 sweep up female seals. which are at once hustled into the killings; he sets the date of July 20, annnally, as the 'latest day' on which seal driving can he permitted,

Note: 1 Dr. Jordan himself knew that the yearling females hanled out with the yearling males, and never on the rookeries with the breeding seals. Yet he shut his eyes deliberately to the riolation of the Carlisle Rules of 1896. Observe the following proof of his knowledge as to what the yearling female does: The following official entry is made in the Treasury agent's journal, St. Paul lsland, on [0. 465, 1under date of "Saturday, Angust 1, 1896": "Dr". Jordan, assisted by the natives, clreve up three small liarems from Garbotch Rookery, and upon investigation found that ihere were a mumber of two-yeur-old virgin cows among them. Pod of 1 and 2 year-old seals was driven from the Reef liookery and was examined with a view to determining whether or not yearling seals were to be found among these youmg bachelors. It is nuw corceded that yeirding females do net hanl out on the rookeries but anc ng the hollusehickie." 
without the killing of female seals." (Hearing No. 14, pp. 950-951, July 27, 1912. House (ommittee on Expenditures in the Department of Commerce and Labor.)

That this law and regulation of the Secretary of the Treasury in 1896 was deliberately violated, as above sworn to, and upon the certified London records, so cited by Mr. Elliott, is clearly shown by the following amazing official entry made by the United States 'Treasury agents in the journal at St. Paul Island Thursday June 9, 1892, and following, to wit (p. 2):

Thursday, June 9. 1892.-Mr. J. Stanley Brown arrived and took the place of Maj. Williams as Inited States agent in chatre of the seal islands.

Friday, July 8, 1892.--The entire control and management of the killing grounds and killing of the seals were given to Mr. Fowler. of the N. A. C. Co., by order of Mr. J. Stanley Brown, agent in charge, and Assistant Agent Murray was ordered to count the seals.

IIere we find that the agent of the Government deliberately surrenders his sworn duty to the agent of the contractors, so that no check upon their killing can be made or will be made by him or his subordinates as to the ages or the sexes of the seals taken.

When Dr. Jorkan eame up here in 1896 with those specific orders of the Treasury Department, duly posted by the agent of the Govelument, as above cited, who was the agent of the lessees?

Mr. J. Stanley Brown," the rery man who, in 1892, as the chief special agent of the Govermment, issued that order surrendering to those lessees all of the Government control of this seal killing.

And he, with the shameful approval of the "scientist" Jordan, to get the 30,000 seals allowed them for that year, violated tha law and regulation of May 14, 1896, by taking more than 8,000 yearlings, which are duly recorded as such in the London sales.

This is the same Joseph Stanley Brown who went over to Paris in 1893 as an "expert," with John W. Foster, and the other tools of the lessees-as an "expert" to plead the cause of the United States in behalf of the fur seal of Alaska before the Bering Sea tribunal. The impression which he made upon that tribunal was not lost; that court saw him clearly (as it did Foster), as the thinly disguised agent of the saal contractors or lessees of the seal islands. He pulled off this disguise next year and went up to tha islands as their (the lessees') hired superintendent.

That this deliberate violation of the rules of the Treasury Department did not cease, and that these rules were annually violated thereafter, the following sworn testimony was givan to the committee May 31, 1911 (Hearing No. 1, p. 10):

Mr. Elliotr. Now, gentlemen, I am going to take up the question of what a yearling fur seal is, because upon a distinct, positive understanding of that you alone can act in this busines?. You can act just as well upon the facts and figures which I lay before you as if you were upon the islands, and I will prove it.

But before doing that, allow me to state that following that memorandum to Senator Burnham I wish to introduce and read the official assertion that yearling male seals were killed for their skins in 1900 and 1901, and the official denial in 1903 that such seals ever were killed for their skins by the lessees of the seal islands-1903 is the year the Senators saw them killed.

The assertion, 1901, report Special Treasury Agent Lembkey-you know him, Mr. Nagel; he is your agent in charge to-day.

f $\int 1$ In his official report dated St. Paul Island, Nov. 1, 1896, Chief Special Agent I. B. Crowley says: The killing is entirely directed by the agent of the lessees, who directs the grade of seal to be taken.' Thus the order of J. Stanley Brown of July 8, 1892, was acquiesced in by both Crowley and Dr. Jordan.

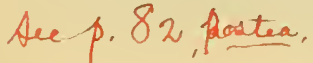


THE ASSERTION

[Report of Special Treasury Agent Lembkey, in charge of seal islands of Alaska, to Secretary of the Treasury, August, 1901.]

The lessees during the season of 1901 took skins ranging from a maximum of 10 pounds to a minimum of 5 pounds. Previous to 1900 the lowest limit of weight was 6 pounds; but a 5-pound limit was established that year, and during the past season as many 5-pound skins as could be found were taken. "Fur Trade Review, New York, Sept. 1, 1901, p. 452.)

Who ordered that "5-pound limit?" Who gave the lessees authority to "establish" that limit in open violation of the specific order not to do it, dated May 14, 1S96?

Why, the seal contractors did; they needed no "authority;" they just used the "order" of the "United States chief special agent, J. Stanley Brown," who, as their own tool in 1894 (also to date), and who, with the consent of their other tools in public service, "established" this illegal and improper killing.

All through these official journals of the United States agent's office at St. Paul Island, from 1896 to 1901 , there is not one word written which even hints at a "5-pound limit" boing "established" in 1900; not a line from the Secretary of the Treasury which alters or amends his order of May 14, 1896; and, up to 1904, these agents of the Government swore to the House Committee on Expenditures in the Department of Commerce and Labor that no rule or regulation of the dapartment had ever been made against their "killing yearlings and seals whose skins weigh less than 6 pounds."

But, this order" against the killing of "yearlings and seals haring skins weighing less than 6 pounds" has been in effect ever since May 14, 1896, and has been annually violated by the lessees ever since that date up to May 1, 1904, when the Hitcheock rules were published to gain the same end, in ignorance of the fact that they had been ordered by the department years ago, and had been suppressed and violated by the lessees and the United States agents up to that clate.

The status of J. Stanley Brown invoked as a defender of the policy of the Bureau of Fisheries, his part, first, as an agent of the Government, in 1892-93, and his action in that office, before he entered the service of the seal contractors, is well set out as follows:

The officialism of the Bureau of Fisheries, when up before the House committee, and testifying as to conduct of the work of killing seals by the lessees under its direction, had the following to say of one of their "scientific" supporters. They introduced him to the committee as follows (Hearing No. 10, p. 519):

Dr. Everuann. Within the last 25 years nearly a score of the most distinguished naturalists not only of this country, but of Great Britain. Canada, and Japan have visited our seal islands for the specific purpose of studying the habits of the fur seals and the problems connected with the proper management of the herd. Among these gentlemen I may mention the following:

Mr. Joseph Stanley Brown, of New York, spent the seasons of 1891, 1892, 1894, 1895, 1896, 1897, and 1899 on the seal islands, where, as naturalist and keen business man, he made very thorough study and investigations not only of the habits of the seals, but very valuable study of the economic questions involved.

Why was Stanley Brown never produced by the Bureau. Why has he never been in evidence? Good reasons, and they are found written upon the official journals of the United States Treasury agent's office at the village St. Paul Island, to wit (p. 2):

St. Paul Island, Thursday, June 9, 1892.-Mr. J. Stanley Brown arrived and took the place of Maj. Williams, as the United States agent in charge of the seal islands. 
Friday, July 8, 1892.- The entire control and management of the killing grounds and the killing of all seals were given to Mr. Fowler, of the N. A. C. Co., by order of Mr. J. Stanley Brown, agent in charge, and Assistant Agent Murray was ordered to count the seals.

Here you see the entire control of the killing as it may be done on islands, the selection, the driving, and time, all surrendered by this sworn agent of the Govermment to the lessees! He actually reduces his office to a cipher and gives the lessees absolute control of the public business with which he is entrusted.

By what authority does Mr. J. Stanley Brown, as the "ehief special arent in charge of the seal islands," make this improper order for himself, and his subordinates? He has nome; no agent ever had. Yet in 1896, when the lessees faced the specific order's of the Treasury Department of May 14, 1896, this man Brown appear's on the seene, as the "superintendent of the N. A. C. Co.," and actually nullifies the same!

When a Democratic administration caused the retirenent of $\mathrm{Mr}$. J. Stanley Brown as the United States chief special agent in charge of the seal islands early in 1893 and placed a Demoeratic agent in his stead (one J. B. Crowley), the lessees at once sent Mr. Brown up and back to look after their interests in their own name for the simple reason that he had proved himself to them as a subservient and trustworthy tool, even when in the service of the Government and as its sworn servant.

ITe took charge of the lessees' interests on the islands, June 6,1894 , and this man has been either up there ever since as the agent of the lessees (lown to the expiration of their lease in 1910; or he has been serving the lessees as a "scientist" before and behind the Bureau of Fisheries in Washincrton, 1). C., when not on the islands. ${ }^{1}$

of course, Dr. Jordan never interfered with Stanley Brown's direction of the killing, after those umpleasant order's of Sceretary

I That Mr. J. Stanley-Brown was busy with these officials and ready to serve them and bis masters, the lessees, up to (late of Dee. 16, 1909, is clearly confessed by the Bureau of Fisheries Itself in the following letter duly produced July 13, 1911, to wit (Hearing No. 5, p. 226, House Committee on Expenditures in the Department of Commerce and Labor):

Mr. Townsend. 1)r. Hornaday, there has been placed in evidence liere a letter written by Barton W. Fvermann, to the Commissioner of the Burean of Fisheries, Department of Commerce and Labor. I will read that letter to you:

DEPARTMENT OF COMMERCE AND LABOR,

BUREAU OF FISHERIES,

Hashingion, Deccmber 16,1909.

The COMMISSIONER:

The Washington Stal of December 10 last announced that the Campfire Club, of New York, had inaugrated a campaign to save the fur-seal herd through legislation designed to prevent the re-leasing of the sealing right, the cessation of all killing on the islands for 10 years except for natives' food, and to secure the opening of negotiations with Great Britain to revise the regulations of the Paris tribunal. $A$ s the result of this movement, on December 7 three resolutions were introdueed by Senator Dixon, of Montana, one of which embodies the provisions before mentioned, the other two ealling for the publication of fur-seal correspondence and reports since 1904.

Is the objeet of this movement is at variance with the program of this bureau and of the reeommendations of the ardvisory fur-seal board, notably in the plan to prevent killing and the renewal of the seal island lease, the advisability is suggested of having Messrs. Townsend, Lucas, and Stanley-Brown use their influence with sueh members of the Campfire Club as they may be acquainted with with the object of eorreetly informing the club as to the exact present status of the seal question and of securing its cooperation to effect the adoption of the measures adroeated by this bureau.

The attarlied letter is prepared, having in view the object stated.

BARTON W. EVERMANN.

Mr. TOWNSEND. Do you know of any effort that was made following this suggestion of the "ad visability" of having matters "explained" in New York.

Mr. IORNADAY. I do. I was told by Mtr. Madison Grant, ehairman of the executive committee of the Zoological Soejety, that Commissioner Bowers liad ealled upon Prof. Osborne and laid before him eopies of the correspondence that liad passed between the Secretary of Commeree and Labor and the Campfire Club, with a statement that was in the nature of a protest against what I was doing in the matter, and with a sort of general request that my activity in the matter should be eurbed; in fact, as it came to me, "That Hornaday shonld be suppressed." I do not know that any such language was used by the comnissioner, but that was the general impression that came to me. 
Carlisle appeared, and were posted June 16, 1896. The understanding must have been perfect between them; for Jordan ${ }^{1}$ in his reports of 1896-97, and final work of 1898 , gires Mr. Jos. Stanley Brown great "credit" for the "valuable aid rendered to this work of investigation," by the said Brown.

To show the committee indisputably how this work of nullifying these Carlisle rules was done on the islands, immediately after their publication thereon, we have made the following copy of the record of the daily killing by the lessees on the Pribilof Islands during the season of is96:

Copied from the official entries marle in the journal of the United States agent in charge of the Island of St. Paul: These entries show that 30,000 seals were killed in June and July, 1S96, and that practieally erery seal driven was killed to get the quota. In other words, all the seals driren, no matter how large or how small, were killed.

I. This official showing makes it clear that the "Carlisle orders" of May 14, 1896, brought to the islands June \&, 1896, were not obeyed either by the lessees or the Government agents in charge. And this official record also substantiates the London sales reeords of the sizes of these 30,000 skins as taken, and sold there in 1896 .

II. And this record also bears out the natives' sworn statement to Messrs. Elliott and Gallagher, agents of the House Committee, Expenditures Department of Commerce, in St. Paul Village, July 24,1913 , that "not before 1896 did we ever receire order's to kill the small seals; we began first in 1896 , to do so," i. e.- "In 1896 , we commenced to take the 5-pound skins to the best of our recollection." (See Exhibit E, postea.)

Copies of the official entries made by the chief special agent of the seal islands of Alaska in the daily journal of the treasury agent's office, on St. Paul Island, which covers the drivingr, killing, and taking of 23,842 skins on St. Paul Island and 6,158 on St. George Island during the season of 1896 (total, 30,000):

Tuesday, June 23, 1896.-A seal drive was made from the west side of Northeast Point, 1,414 seals were killed. All the skins were accepted. (P. 16.)

Wednesday, June 24, 1896. - A seal drive was made from the east side of Northeast Point, 1,408 seals were taken. The skins were all accepted by the lessees. (P. 16.)

Saturday, June 27, 1896.-A seal drive was made from Reef, 2,076 seals were killed and their skins were accepted by the lessees, and salter in the village salt house. (P. 17.)

Ifonday, June 29, 1896. - A seal drive was made from English Bay and Tolstoi, 1,398 sealskins were accepted and salted in the village salthouse. (P. 17.)

Thursday, July 2, 1896. - The drive made from the west side of Northeast Point, 1,374 seals taken and accepted. (P. 17.)

I The value of Dr. Jordan's "authority" for this illegal and injurious work on the islands is modestly given to the House Committee by United States Commissioner Bowers as follows (pp. 109-111, Hearing No. 2, House Committee on Expenditures in the Department of Commerce and Labor, June 9, 1911):

Mr. BowERS. The members of the fur-seal board and of the advisor: boarl, fur-seal service, are as follows:

Dr. David Star Jordan, president of Stanford Cniversity, who was chairman of the International Fur Seal Commissions of 1896 and 1897 , appointed in pursuance of the treaty of Februars 29, 1\$92, and who:0 published report in four volumes is the most comprehensive, thorough, and valuable treatise that has ever been published on all matters pertaining to the fur seal and the seal islands. Dr. Jordan is the most distinguished and best known naturalist in the world.

Mr. Bowers. I had in mind getting the best talent I could; l expected probable criticism.

Ir. TOWNSEND. I am not eriticizing you now.

Mr. Bowers. I endeavored to get the best talent it was possible to get and to act upon their advice in this fur-seal matter.

$11864-13$ 
Friday, July 3, 1896. - A seal drive was made from west side of Northeast Point resulting 1,109 skins. Twn "road skins" not accepted." (P. 18.)

Monday, July 6, 1896. - Seal drive made from Lukannon and Zoltoi sands, 1,535 seals were taken and accepted by the lessees. (P. 18.)

Tuesday, July $\%, 1896 .-$ A seal drive was made from Zapadnie resulting in 784 sealskins being accepted by the lessees. (P. 18.)

Wednesday, July \&, 1896.-- d drive was made from Polavina, 961 skins taken. (P. 18.)

Friday, July 10. 1896.- Seal drive from Reef and Zoltoi, 1,271 sealskins being taken. (P. 19.)

July 11, 1896.--Jordan arrives, with his party, Thompson, et al. (P. 21.)

Tuesday, July 14, 1896. - Seal drive made from east side of Northeast Point; 1,169 seals taken. (P. 22.)

Wednesday, July 15, 1896.- Seal drive made from Reef and Zoltoi. The drive and killing was attended by commission and officers off the Albatross. ${ }^{2}$ (P. 22.)

Thursday, July 16, 1896.--Seal drive made from English Bay and Tolstoi; 1,138 killed. (P. 22.)

Tuesday, July 21, 1896.- Seal drive made from west side of Northeast Point; 808 seals were taken. (On the $22 \mathrm{~d}$, east side driven; 1,047 seals taken.) (P. 23.)

Thursday, July 23, 1896.- Seal drive from Half Way Point; 585 seals taken. (P. 23.)

Saturday, July 25, 1896. - Seal drive made from Lukannon, Ketavie, Zoltoi, and Reef; 1.630 seals taken. Up to date 5,858 have been taken on St. George Island. (P. 23.)

Monday, July 27, 1896.-Seal drive from Middle Hill and Tolstoi; 504 seals were killed, being 112 short of the number required $(30,000)$ to complete the quota. In order to complete the same a drive was made from Lukannon rookery and the 112 seals secured. (P. 24.)

Sunday, August 23, 1896.-The Homer left at 3:30 p. m.; had on board 30,000 sealskins; 23,842 from St. Paul and 6,158 from St. George. (P. 473.)

Then we find that in 1897 this taking of the small skins, as above, in 1596 was continued, as the explicit adnission is made of that many "5-pound" skins were taken in the following entry, made in this journal, to wit: The United States special agent says:

Monday. July 5, 189\%. - A drive of seals was made from Reef and Zoltoi with the following results: Killed, 703. * * * Many of those tumed off as too large in the early part of the season were killed to-day, and I noticed a desire on the part of the lessees' agent to secure both small and large skins as the seals came along. Many were killed whose skins would weigh 10 pounds and over, while, on the other hand, many were taken whose skins would weigh from 5 pounds to $6 \frac{1}{2}$ pounds each.

That this killing by the lessees on the islands was actually without restraint on the part of Lembkey and his official assistants is confessed most unwillingly in the following statement, made September 30,1909 , by Geo. A. Clark in his official report to the Bureau of Fisheries (and which report U. S. Commissioner Bowers suppressed), to wit (pp. 829-866, of Appendix A; House Committee on Expenditures in the Department of Commerce and Labor, June 24, 1911):

(Original report examined by commissioner Oct. 8. Turned over to Mr. Lembkey Oct. 9.)

REPORT ON CONDITION OF FUR-SEAL HERD, 1909.

Hon. George M. Bowers,

Commissioner of Fisheries, Washington, D.C.

SrR: I have the honor to submit herewith my detailed report on the condition of the fur-seal herd on the Pribilof Islands, resulting from the investigations of the past summer in accordance with your instructions of May 15, 1909, as follows:

It is on the killing field, however, that the great need of a guiding and controlling hand is shown. In 1896-97 the Government agents ordered the drives. $\$$ This season

1 This is the only record of rejection of skins-"Two road skins not accepted." Only two skins missed out of the 30,000 that they killed in 1896 , or rather the 23,812 seals killed on St. Pauls Island $(6,158$ on St. George) during the season of June-July, 1896. A clean sweep.

2 Thls is all of the entry.-(H. W. E.)

$\phi$ Seep. 78 , antea. 
they have been entirely in the hands of the lessees. The young males set aside for breeding purposes having been marked, the lessees have been free to take what they could get, and this resulted in their taking practically all of the bachelors appearing on the hauling grounds. In the eagemess to see that no possible bachelor escapes, the edges of the rookeries are encroached upon and cows included in the drives. Fifty of them appeared in drives toward the close of this season. A drive that can not be made without including cows should be omitted. A drive which appears on the killing field with 15 to 20 cows in it should be released rather than incur the danger of clubbing any such cow by mistake. There should be some one in charge of the herd with power and discretion to do this.

There has been on the killing grounds since 1900 a constant struggle on the part of the leasing company in the closing years of its concession to get every possible skin from the declining herd. Its work has been aided by a high arbitrary legal quota and by a lowered minimum weight of skin, enabling it to gradually anticipate the quotas of succeeding years by killing younger animals. As a result there has occurred in these years probably the closest killing to which the herd has ever been subjected. Aside from the diminished supply of male life on the breeding grounds in 1904, this is shown in the fact that though the herd has declined two-thirds in size, the quota has never fallen more than one-third in size as compared with that of 1897 .

With a declining herd this close killing has not been so important as it would be in the case of an increasing herd. Fewer and fewer bulls have constantly been needed on the breeding grounds. Of the 5,000 bulls occupying harems in 1896 , only 1,387 were needed in 1909. A diminished breeding reserve has therefore been possible. But we must consider a reversed condition of things, if pelagic sealing is to be done away with. The herd will then begin to grow. It will require a constantly increasing reserve of breeding males, which must be saved from the killing fields. A leasing company will be just as eager to get all possible skins and will press the product of the hauling grounds, rising all too slowly, to its limit unless restrained.

Respectfully submitted.

George Archibald Clark, Assistant in Charge of Fur-Seal Investigation.

Stanford University, September 30, 1909.

This explicit confirmation of the eharges which Elliott had made against the work of the lessees and their confederates so disturbed Bowers and the lessees, who were scheming to renew the lease, May 1 , 1910, that the following disposition of Clark's report was made, to wit:

Departuent of Commerce and Labor, BUREAU OF FISHERIES, Washington, November 17, 1909.

Mr. W. I. LEMBKEY,

Bureau of Fisheries, Washington, D. C.

SIR: Assuming that you have read and carefully considered the fur-seal report recently made by Mr. George A. Clark, who visited the islands during the past summer, I desire that you prepare a statement of your views regarding the report, particularly with reference to such data and conclusions contained therein as do not agree with your understanding of the facts and conditions.

Kindly let me have this statement in form convenient for use at the conference of the advisory board next Tuesday.

Respectfully,

Geo. M. Bowers, Commissioner.

Lembkey did his work of "explaining" to that advisory board the errors of Clark's report so well that when it assembled in Bowers's office, November 23, 1909 ("next Tuesdar"), thefollowing official and "unanimous recommendation" was made that the lease be renewed:

Mr. Bowers. On November 23, 1909, there was a meeting of the advisory board with the fur-seal board and the Commissioner of Fisheries and Deputy Commissioner of Fisheries (Dr. Hugh M. Smith), at which were present also Mr. Chichester and Mr. George A. Clark. After mature deliberation these gentlemen unanimously agreed upon the following recommendations: 
1. It is recommended that the agent in charge, fur-seal service, shall, under the direction of the Secretary of Commerce and Labor, have full power to limit or restrict the killing of fur seals and blue foxes on the Pribilof Islands to any extent necessary and that no specified quota be indicated in the lease.

2 . It is recommended that for the present no fur-seal skin weighing more than $8 \frac{1}{2}$ pounds or less than 5 poumds shall be taken, and that not more than 95 per cent of the 3 -year-old male seals be killed in any one year.

Mr. Bowers. I had in mind getting the best talent I could; I expected probable criticism.

Mr. Townsend. I am not criticizing you now.

Mr. BowERs. I endeavored to get the best talent it was possible to get and to act upon their advice in this fur-seal matter. (Hearing No. 2, pp. 110, 111, June 9, 1911, House Committee on Expenditures in the Department of Commerce and Labor.)

And still more, it will be observed that Mr. George A. Clark attends this "nuanimous" conference, as above reorded, and becomes party willingly to that renewal of the lease and that close killing on the islands. 'The following official "orders" explain it, perhaps:

\section{DEPARTMENT OF COMMERCE AND LABOR,}

BUREAU OF FISHERIES,

Washington, November 1, 1909.

Mr. GEO. A. CLARK

Stanford University, Cal.

Sir: Your orders of May 7, 1909 (No. 547), are hereby extended to April 1, 1910 , and you are instructed to come to Washington for the purpose of explaining and further elucidating your report on the condition of the fur-seal herd based on your observations during the past summer.

You will be allowed a compensation of $\$ 10$ for the time so employed and your necessary expenses of travel and subsistence during the performance of such duty, payable from the appropriation "Statistics and methods of the fisheries."

Respectfully,

Geo. M. Bowers, Commmissioner.

\section{EXHIBIT C.}

The Kate and Anna-Official records which declare her to have been a pirate sealing schooner around St. Paul Island, in July and August, 1890 -Said schooner is the same "just and valid" claimant against Russia which H. H. D. Poirce, as "Third Assistant Secretary of State," and (. H. Townsend, as "sealing expert, U. S. Bureau of Fisheries," put up at The Hague, June-July, 1902, and which puts her in the same class with the Jas. Hamilton Lewis, another pirate ship also rouched for by Peirce and Townsend at The Hague, June-Julv, 1902.

Extracts from the official records which declare the Kate and Anna to have been a pirate ship, and not properly vouched for at The Hague by Peirce and 'Townsend, who presented her as follows:

Mr. Peirce. I was requested to act by one George R. Tingle, who was the attorney of record for the owners and crew of the James Hamilton Lewis; and in the case of the C. H. White and the Kate and Anna, the same request was made by James Embry, who was the counsel of record for the C.H. White and the Kate and Anna. (Hearing No. 12, p. 781, Lay 29, 1912, House Committee on Expenditures in the Department. of Commerce and Labor.) 
OFFICIAL RECORDS IN RE THE "KATE AND ANNA" (SEALING SCHOONER) - PROOF THAT SHE WAS A "PIRATE" AROUND ST. PAUL ISLAND, 1890-TAKEN TO THE HAGUE BY PEIRCE AND TOWNSEND IN 1902, AS A "JUST AND VALID CLAIMANT" AGAINST RUSSIA.

In re Kate and Anna. Official entry in St. Paul's journal by J. P. Manchester, United States special agent in charge (p. 24):

August 8, 1890.-At 11 a. m. U. S. revenue cutter Rush in sight at east end of the island after the schooner; $12.30 \mathrm{p} . \mathrm{m}$. she captures schooner about 10 miles east of the village. Good deal of excitement among the people over this, as this schooner lias been around and near the island many times this summer. About $7 \mathrm{p}$. m. Capt. Sheppard came ashore and reported the schooner was Kate and Anna, 582 skins.

The "pirate" schooner Kate and Anna. Special Agent Jos. Murray enters in St. Paul official journal (p. 275):

Thursday, September 4, 1890.-Antone Melovidov telephoned from N. E. P. that the schooner was anchored there and had three boats out with hunters killing seals witlin half a mile of land.

From Cross Hill he watched them through a glass and counted 10 or 12 shots fired for one seal secured by the hunters.

It was the same schooner that has been around the islands for several weeks and which was overhauled last week and released by the Rush. The name of the schooner is the Kate and Anna, Capt. Lutzen, of Portland, Oreg.

Saturday, September 6, 1890.-Antone is still at N. E. Point and telephoned this morning that the same schooner (Kate and Anna) had anchored there last night and is still there to-rlay. (P. 276.)

Sunday, September \%, 1890.--Schooner Kate and Anna still at N. E. Point fishing for seals within 1 mile of the shore. Thus far there bas not been any attempt made to land. * * * I feel humiliated as I watch the pirates shoot the seals almost within range of the rifle in my own hands. (P. 277.)

Ironday, September 8, 1890.- Schooner still at N. E. Point. No attempt made to land yet, nor do they need to come asbore for seals so long as they can lower nets down and capture all they can carry off without serious protest by anyone. (P. 277.)

September 9, 1890.-Antone Melovidov leturned from N. E. Point and reported the departure of the schooner. (P. 278.)

September 10, 1890.--Revenue cutter Bear anchored here at noon from Oonalashka and several of her officers came ashore for a few hours. * * * The Bear weighed anchor and went down to N. E. Point. (P. 278.)

September 11, 1890.-The Bear is anchored at N. E. Point. (P. 278.)

September 15, 1890.- The Bear left to-day for St. George and Oonalashka. (P. 281.)

September 16, 1890. - The Bear returned from St. George this afternoon and anchored at N. E. Point. (P. 281.)

September 17, 1890.-Capt. Healy says that he anchored at N. E. Point last night, because he knew a schooner coming to St. Paul would be more apt to anchor there than at any other point around the island. (P. 281.)

September 18, 1890.-The Bear left N. E. Point last night and we suppose went to Oonalashka. (P. 282.)

In view of this record officially made by agents of our Goverument, it is interesting to review the testimony given below by other agents of our Government who indorsed this pirate ship, as a proper claimant against Russia, in 1902.

H. H. D. Peirce, under oath, May 29, 1912, tells the House committee that he took the case of the Kate and Anna to The Hague as a just and valid one, when the official records of the Treasury Department declared her in 1890 to have been a pirate and then busyraiding the seals near our own islands (less than one-half mile from shore).

\footnotetext{
1 This is one of the four vessels handled by those public agents (Peirce and Townsend), viz, Jas. Mamilton Lewis, the C. H. White, the Kate and Anna, and the whaling barque Cape IIorn Pigcon, the Lewis being a notorious pirate owned by Liebes, lessee, seal islands.
} 
[Hearing No. 12, p. 780, May 29, 1912, House Committee on Expenditures in the Department of Commerce and Labor.]

The Chairman. Did you represent anybody before The Hague tribunal in the dispute with reference to the James Hamilton Lewis case?

Mr. Peirce. I did, sir. I represented the owners, officers, and crew of the Cape Horn Pigeon, an American whaling vessel, arrested in the Sea of Okhotsk; the James Hamilton Lewis, an American sealing vessel, arrested in the Bering Sea; the C. $H$. White, an American sealing vessel, arrested in the Bering Sea; and the Kate and Anna, another sealing vessel, also arrested in the Bering Sea; and subseqeuntly I was appointed, as a matter of formality, in orcler to give me a status in the court, nominal counsel for the Government in the arbitration.

The Charrman. First of all, how did you happen to be employed to represent these various interests before The Hague tribunal?

Mr. Peirce. As secretary of legation I had become very familiar with all of the cases, for the Government had repeatedly instructed the legation to urge upon the Russian Government the settlement of these claims, and so I had become very familiar with them. They commenced in the year 1892, if my memory serves me aright, and I was appointed in 1894, and then, after the cases had been brought to an agreement to arbitrate by Ambassador Tower's convention, which, owing to his absence, I signed, the attomeys for the Cape Horn Pigeon and the James Hamilton Lewis and subsequently the C. H. White and the Kate and Anna, requested the Secretary of State to permit me to act as counsel and requested me to so act.

C. H. Townsend, as an "expert" of the United States Bureau of Fisheries, aided him.

[H(aring No. 12, p. 783, May 29, 1912.]

The Chairnan. You finally settled. You may tell the committee what your compensation was, if you will.

Mr. Peirce. Certainly. My compensation in the case of the C. H. White and I think also the Kate and Anna-I am not sure of that-no; my compensation in the case of the $C$. H. White, for which I recovered an award of $\$ 52,000$, was $\$ 5,000$, less my counsel fees, which amounted to $\$ 1,000$. I received $\$ 4,000$.

The Chalruan. Did anybody else receive any compensation?

Mr. Peirce. I do not know. I presume James Embry got a large compensation, but I do not know.

The Chairman. Who went with you to The Hague Tribunal?

Mr. Peirce. Mr. Townsend. I forget his initials.

The Chairian. Charles Townsend.

Mrr. Peirce. He had been employed, I think, by the Treasury Department when the care of the seal herd was under the Treasury Department.

The Chairian. He was sent with you as an expert?

Mr. Peirce. As an expert.

The Chairvan. To assist you in presenting the case?

Mr. Peirce. Yes, sir; as a witness.

The Chairman. Did he receive any compensation?

Mr. Peirce. That I do not know. He received, if my recollection serves $\mathrm{m} \geq$ aright, his traveling expenses, which I think I paid to him, to be refunded out of the award.

[Hearing No. 12, p. 758, May 24, 1912, House Committee on Expenditures in the Department of Commerce and Labor.]

Mr. MADDEn. The question is whether Mr. Townsend is in a position to know the facts.

The Champian. I thought he was, because he was with Mr. Peirce at The Hague Tribunal. Tere you in the employ of the Government at that time, Dr. Townsend?

Dr. Townsend. I was in the employ of the Fish Commission, and was transferred temporarily to the State Department.

The Chairian. I do not want him to make a statement that he can not substantiate, but I would like to know now, Dr. Townsend, in what capacity you wore at The Hague Tribunal in this matter?

Dr. Townsend. In the progress of the work before The Hague Tribunal it became necessary for the Secretary to produce information on various sealing matters, such as the movements of sealing vessels. I carried along with me a trunk full of $\log$ books of sealing vessels. We would have before us the charges made by the Russian representative during the day, and we would work all night preparing something to refute the charges. I carried the $\log$ books that had been taken from the vessels. 


\section{EXHIBIT D.}

The condition of the natives' houses, and natives on St. Georges and St. Pauls Islands. Season of 1913. Inspected July 17-22, by Henry W. Elliott, Andrew F. Gallagher, agents of the House Committee on Expenditures in the Department of Commerce.

THE CONDITION OF THE HOUSES OF THE NATIVES OF THE SEAL ISLANDS, IN THE VILLAGES OF ST. GEORGE AND ST. PAUL, JULY $17-22,1913$.

During the progress of the testimony given to the House Committee on Expenditures in the Department of Commerce and Lahor (hearing No. 3, pp. 144, 145, 146, and 162) the question below was raised and answered (House Committee on Expenditures in the Department of Commerce and Labor):

The Chairian. One moment, please; I will ask you some questions, and then you can make your statement. I had information that was gathered from the correspondence and the terms of the lease under which the Commercial Co. operated, that on June 30,1910 , there was paid out by the Government $\$ 23,960$ for houses for the natives up there, and if my conclusions are correct the lessees should have paid that instead of the Government. What do vou know about that?

Mr. Elliotr. Your conclusions are correct. These houses belonged to the natives when the old lease expired; then when the new lease was invited the condition was imposed by the Secretary of the Treasury that whoever got that lease should do as much for the natives as the old lessces had clone; that is, they should house these people, put them into the dwellings, and pay for it themselves. The North American Commercial Co. by the terms of its lease entered into that covenant with the United States on March 12, 1890, and agreed to do as much for the natives as the old lessces had done; they had to give them these houses free from any recourse on the United States as part of the obligation of their own in getting the lease.

The CHAIRMAN. Then I understand that the natives are entitled to the houses?

Mr. Fllotott. Yes, sir; the houses were given to them in 1878 and 1880.

The CHAIRMAN. I am more particularly interested in the question of this payment of the sum of $\$ 23,960$.

Mr. Erlotot. The North American Co. assumed that obligation for the old lessees. The old lessees never entered into that obligation with the United States; that was a matter of their own gift to the natives in 1872 and 1874-1878.

The Chamman. But the Government appears to have paid it in the end?

Mr. Elliotr. The Government bought nothing, either from the old lessces or the new lessees; but the new lessees were obligated to buy these houses or else build new ones and to turn them over free from any recourse on the United States Government; that is, to give them to these natives.

Mr. Young. The lease was made on the 1st of May, 1890?

Mr. Elliotr. Yes, sir; but the preliminaries were agreed upon on March 12, 1890.

Mr. Young. This seems to be the language of the contract:

"That it will also furnish the said inhabitants a sufficient number of comfortable dwellings in which said native inhabitants may reside, and will keep said dwellings in proper repair, and will also provide and keep in repair such suitable schoolhouses as may be necessary, and will establish and maintain during eight months of each year proper schools for the education of the children of said islands. * * * $\Lambda 11$ of which foregoing agreement will be done and performed by the said company free of all costs and charges to said native inhabitants of said islands or to the United States."

Now, is not that lease subject to this construction: That while the lease was in operation it was the duty of these lessees to furnish and repair these houses for the natives, but at the termination of that lease, is it not a fact that the houses built lyy these lessees became their own property?

Mr. Elliotr. No, sir; because in 1872 and 1874 the first of these houses was voluntarily built and given to these natives by the old lessees. By 1881 they were all housed free of any charge by the old lessees, as a gift to them in which the Grovernment had nothing to do, either of suggestion or action. That agreement between the old lessees and the natives as to these houses was not thought of at the time that that 
lease was granted; but when they came to renew the lease the old lessees put up the plea that the lease ought to go to them, because they had gone into this thing voluntarily and furnished the houses as a gift to the natives, and that that ought to be considered in their favor. Therefore, when the new bidding was invited, the new bidders had to bid to do just as much voluntarily, without any recourse on the United States, as the old bidders had done. Thereiore, the new lessees bid to do exactly what thai lease calls for; that is, to furnish these houses free, just as the old lessees had furnished them, without any recourse on the United States.

Mr. Young. This contract between these lessees and the Government has no provision as to where the title to these houses shall go after the expiration of this lease. Then, the question with me is, to whom do these buildings belong?

Mr. ElliotT. They belong to the natives, but you can not give them title, because the houses are on a Government reservation. The new company had to buy them from the old company or else build new ones. This was a gift by the old company not thought of at the time their lease was granted. It was their own voluntary gift. This was officially reported on in the Monograph on the Seal Islands, published by the Tenth Census, in 1850 . You will find it on page 24.

Mr. Young. What was the amount the new company paid to the old company?

Mr. Elliotr. Something like the amount you have mentioned.

Mr. Young. $\$ 23,960$ ?

Mr. Elliott. Yes, sir. The oll company had to give up that lease, but the new company had to assume every ohligation that the old company had incurred, and this obligation of $\$ 23.960$ they assumerl without recourse on the United States.

The Chanmax. Do we understand you to say that the Government paid this amount when, in fact, the old lessees were liable to pay it?

Mr. Elllote. Yes, sir: and they did pay it.

Mr. McGillicudoy. How would the old company be liable for it after the lease was canceled and the Government assumed the business itself?

Mr. Elliott. The old company passed away with the first lease, of course, but the obligation of the old company was assumed by the new one.

Mr. MCGillicudDr. But they would not he under any obligation to house the natives atter the lease was ranceled?

Mr. Elliott. But hefore they got the lease they had to assume that obligation of the old company.

Mr. McGillicudor. You mean that the last company assumed it?

Mr. Ellıotт. Yes, sir.

Mr. McGillicudor. Uniler the terms of that first lease, the lessees would not be liable to house any of the natives atter the lease expired?

Mr. Eldiotr. They were not liable before the expiration, but they volunteered to do so and did so.

Mr. MCGILLICUDDY. But this $\$ 23,960$ was paid out after the cancellation?

Mr. ElliotT. But that was a part of the terms or conditions under which they secured the lease. Before they canceled the lease they had to assume this obligation of the old company.

Mr. McGillicendy. But there was no obligation to build houses after the lease expired?

Mr. Elliotr. No; they were, nevertheless, obligaterl to take the same stand that the old company took and they agreed to assume all of the obligations of the old company.

Mr. Mcrillicuddi. I can not see how the lessees would be liable for the housing of any of the natives after the lease was canceled.

Mr. Elliot They are not liable; but these houses have belonged to the natives since 1873 and $1874-1878$.

Mr. Bowers. Who built them?

Mr. Eiliotr. The old company.

Mr. Bowers. Who bought them irom the old company?

Mr. Elliott. The new company.

The Chamman. Do I understand you to say that when the new company got the lease there was a condition imposed that they would pay for these houses?

Mr. Elliotr. Certainly; to either pay for the old company's houses or build new ones without recourse on the United States Government.

The Charman. And that is the way the proposition stands?

Mr. Elliott. Yes. sir.

The Chalrman. Here are some papers relating to this subject. I do not know whether they should be put in the record, but that matter can be consilered later by the committee. Please examine this paper and identify it. 
Mr. ElLiott. That is the official list of the natives' houses.

Mr. Young. I was somewhat confused by this list of houses for the natives. The law on the subject is contained in section 9 of the act approved April 21. 1910. which reads as follows:

"SEC. 9. That the Secretary of Commerce and Labor shall have authority to appoint such additional officers, agents, and employees as may be necessary to carry out the provisions of this act and the laws of the United States relating to the seal fisheries of Alaska, to prescribe their duties and to fix their compensation; he shall likewise have authority to purchase from the present lessee of the right to take seals on the islands of Saint Paul and Saint George. at a fair valutation to be agreed upon, the warelouses, salt houses, boats, launches, highters, horses, mules, wagons, and other property of the said lessee on the islands of Saint Paul and Saint George, including the dwellings of the natives of said islands; he shall hikewise have authority to establish and maintain depots for provisions and supplies on the Pribilof Islands and to provide for the transportation of such provisions and supplies from the mainland of the United States to the said islands by the charter of private vessels or by the use of public vessels of the United States which may be placed at his disposal by the President; and he shall likewise have authority to furnish food, shelter, fuel. clothing, and other necessaries of life to the native inhabitants of the Pribilof Islands and to provide for their comfort, maintenance, education, and protection.'

I believe that ought to be inserted in the record in connection with what we have gone over.

The Chatrman. I understood from Mr. Elliott's statement that it was his theory that the buildings had to be accounted for by the lessees and should not have been purchased by the Government.

Mr. Elliotr. Certainly; they do not come into the "plant" at all.

The Chairmax. So that I think perhaps it is well enongh to have that in.

Mr. Elliotr. The native dwellings that belong to the "plant" should be purchased.

The terms of this lease which bound the lessees to furnish these native houses to the natives free of all cost to the L'nited States, and also keep them in repair during the period of the lease free of all cost either to natives or the United States, are found as follows in the body of the contract signed March 12, 1890, to wit (see p. 467, Hearing No. 10, House Committee on Expenditures of the Department of Commerce and Labor):

That it will also furnish to the said inhabitants 80 tons of coal annually, and a sufficient number of comfortable dwellings in which said native inhabitants may reside; and will keep said dwellings in proper repair; and will also provide and keep in repair such suitable schoolhouses as may be necessary; and will establish and maintain during eight months of each year proper schools for the education of the children on said islands, the same to be taught by competent teachers who shall be paid by the company a fair compensation, all to the satisfaction of the Secretary of the Treasury; and will also provide and maintain a suitable house for religious worship; and will also provide a competent physician or physicians and necessary and proper medicines and medical supplies; and will also provide the necessaries of life for the widows and orphans and aged and infirm inhabitants of said islands who are unable to provide for themselves: all of which foregoing agreements will be done and performed by the said company free of all costs and charges to said native inhabitants of said islanids or to the United States.

There is no ambiguity in this clear specific obligation of the lessees to furnish these native houses to the natives free of all cost at any time to the Government of the United States or to the natives themselves. That payment to them, by Secretary Nagel, of \$24,000 for those houses, is not warranted and should be recovered.

In the first $\mathrm{p}^{1}$ ace, these houses are small wooden one-story frame structures, 20 by 10 , on the sills, and no attic, with an outer shed or "calle dore" over the entrance: the entire cost, when first built by the Alaska Commercial Co. in 1876 (and then given by that lessee to the natives), was between $\$ 210$ and $\$ 225$ per dwelling. 
They have been well painted and kept in tolerably good shape year after year by the lessees, up to the close of their lease, May 1, 1910 , then by the Government up to date, as the following inspection will attest:

They all have one living room 10 by 10 , and a bed room 8 by 10 , with that outside shed or "hall" ("callidore"). There is a little variation only in this place, by the fashion of attaching this callidore to the main building: some bringing it out flush. to the front line of the house, others setting it back; some have widened it more, and so on; the average callidore is 5 by 14 feet.

These dwellings are too small for those natives who have several children, since they allow of only one small 8 by 10 bedroom, that

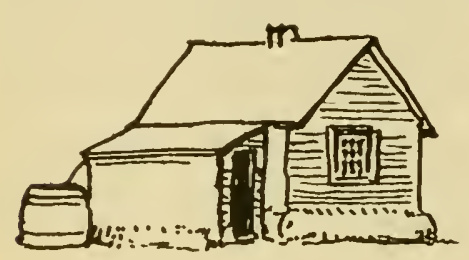
compels them to sleep crowded, and often badly crowded, into these small rooms.

Nevertheless, these people when asked by us made no complaint of being insufficiently fed and clothed or warmed by the Government under existing orders and regulations. The annual sum allowed them for food, clothing, and fuel

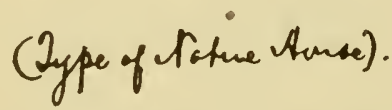
should not be less than $\$ 35,000$, which is a fair amount for that end. They should not be reduced from that sum, for the annual maintenance of 302 souls up here, in a very simple life, requires it.

INSPECTION OF HOUSES ON ST. PAUL ISLAND, TUESDAY, JULY 22, 1913.

This inspection was made by Messrs. Elliott and Gallagher, agents House Committee on Expenditures in the Department of Commerce, accompanied by Nicoli Kizlof, interpreter.

House No. 1.-Government warehouse.

House No. 2, Jacob Kochutin.-Tenant in Unalaska. Outwardly this house appears to be all right.

House No. 3, Dorofai Stepetin.-House in good condition. Husband in Unalaska working.

House No. 4, Tassilisa Peeshnikov, widow.-Floor of colidor needs repairs. Balance of house in good condition.

House No. 5, Simeon Vozikov.-House in good condition.

House Yo. 6, John Merculiev._-Floors repaired last winter. House in good condition.

House No. 7, John Fratis.-House in good condition.

House No. 8.-Gorernment house, not occupied.

House No. 9, Mary Emanof, widow.-Tenant not in; door locked.

House No. 10, Alexander Galateanof.-Roof leaks. Floors all right. Tenant claims his house is too small.

House No. 11, Paul Merculiev.-Tenant on watch. House locked. Nobody home.

House No. 12, Appolon Bordokufsky.-Tenant in Unalaska working. House locked. House looks all right from outside. 
House No. 13, Neil Oostigof.-Tenant in Unalaska working. House looks all right from outside.

House No. 14, John Meseekin.-House in good condition.

House No. 15. - This house is a native's shop and club house.

House No. 16, Eleta Bogdanof, widow.-House in good condition.

House No. 17, Mokenty Seedick.-Floor is rotting. Otherwise the house is all right.

House No. 18, Nicoli Kuzlof.--House in good condition. The colidor leaks somewhat.

House No. 19, Stephan Rukovisnikof.-Roof bad and leaks. Everything else all right.

House No. 20, George Shaishnikov.-Door locked. Tenant absent, in Unalaska.

House No. 21, Mike Kushin.-House in good condition.

House No. 22, Mike Kuzlov.-Roof leaks. Floor all right. Otherwise house all right.

House No. 23, John Krukoff.-House in good condition.

House No. 24, George Korchugin.-Roof leaks. Floor all right. Otherwise house in good condition.

House No. 25, Elari Stepetin.-Roof leaks. Floor all right. Otherwise in good condition.

House No. 26, Vlass Pankof.-Roof leaks. Floor bad.

House No. 27, Nikita Hapov.-Roof leaks, floor bad, and sills rotting.

House No. 28, Theodore Seedick.-House in good condition.

House No. 29, Oleana Gromov, widlow.-House in good condition. tion.

House No.30, Matroona Balaxine, widow.-House in good condi-

House No. 31, Paul Merculiev.-House in good condition.

House No. 32, John Stepetin.-- Hall floors are rotten. Roof is all right and house in good condition otherwise.

House No. 48.-Government laboratory.

House No. 47, John Kachootin.- Sills of floors are rotten surrounding the house. Roof is all right. Otherwise the house is in good condition.

House No. 46, Metrofan Krukov.--Roof leaks. Floors all right. Otherwise house in good condition.

House No. 45, Katrina Krukov, widow.-Tenant in Lnalaska, but the son says the floor is bad. The roof is all right and otherwise the house is in good condition.

House No. 44, Parascovia Kozlof, widow.-Roof bad, otherwise the house is in good condition.

House No. 43, Carp Buterin.-House in goorl condition.

House No. 42, Paul Kozmivnikof.-Roof and floors bad.

House No. 41, Peter Oostigov.-House in good condition.

House No. 40, Zenovia Kochootin, spinster.-Floors bal, but roof all right. Otherwise house in good condition.

House No.39, Alexander Melovidov.-House in good condition.

House No. 55, Peter Tietov.-This is the best house in the village. House in very good condition.

House No.5\%, Neetor Kushin.-Roof leaks. Floor is all right.

House No. 53. - An empty house, in rery bad condition; simply a shack, out of repair.

House No. 52, Porfiri Pankof.-House in good condition. 
House No. 51, Zachar Tietof.-Floors are bad.

House No. 50, Constantine Booterim.-Roof is bacl.

House No.38.-An abancloned house. Rotting sills; roof gone, merely a shack.

House No. 37, Conrad Krukof.-Roof is bad, floors all right. Otherwise house in good condition.

House No. 36, Ivantie Fozerof.-Roof bad, floors bad, and sills rotten.

House No. 35, Neon Tietof.-House in good condition.

House No. 34, Trefan kochootin.-Tenant in Unalaska. House locked. From outward examination it appears to be in good condition. Natives have a bowling alley between houses 34 and 33 .

Ifouse No. 33, Theodore Kochootin.--House in good condition.

House No. 56 , Acolena Tratis, widow.-Nceds shingling. Otherwise house in good condition. Natives have a library and billard room, which they constructed and hold in their own name, and also a town or public hall, in which they hold meetings, dances, and work on their boats, ete.

Recapitulation.--July 1-30, 1913. St. Paul's village. There are 50 families living in these houses with 196 souls, men, women, and children. There are 24 families lining in the houses on St. George Island, with 106 souls, thus showing a native population of the Seal Islands on July 1, 1913, of 302 souls.

They are the same people, and living just as they were, in 1890, and as fully deseribed in House Document 175, Fifty-fourth Congress, first session, pages $109-127$.

INSPECTION OF HOCSES ON ST. GEORGE ISLAND, THURSDAY AFTERNOON, JULY 17, 1913.

This inspection was made by Messrs Elliott and Gallagher, agents House Committee Department of Commerce, accompanied by Messrs. Procter and Hatton, and Drs. Mills and Murphy, agents of Bureau of Fisheries.

House Vo. 1, Demetri Lestenkoff.--Some repairs should be made to sills. Sills rotten and should be replaced.

House No. 10, Alexander Galanin.-Mr. Procter states from his own knowledge that this is one of the houses on which the roofs were repaired, reshingled, and resheathed.

House No. 9, Anatoli Lekanoff.-House in good condition.

House No. 2.-Unoccupied, but in good condition.

House No. 7 , Demetri Philomonoff.--House in good condition.

House No. 3, Andronic Philomonoff.-Made repairs under the floor of calidor, last fall, 1912. This house is in fair repair.

House No. 6, Stepan Lekanoff.-Addition put on house about five years ago. House is in very fair condition and repairs slight.

House No. 4, John Galanin.-House in good condition.

House No. 5, Nicoli Merculioff.-House in good condition.

House No. 12, Mike Shane.--House in good condition.

House No. 13, Peter Prokopiof.-With the exception of sill, which is rotting, the house is in good condition.

House No. 14, Simeon Phitimonof.-House is in good condition except roof on calidor leaks. 
House No. 15, Paul Swetzof.-House is in good condition, but needs slight repairs.

House No. 16, Ripsimian and Wassa Malavansky (widows).House in good condition.

House No. 17, Mike Lestemk of.--House in good condition.

IIouse No. 18, Nicoli Malavansky. - Needs slight repairs to sills. Otherwise in good repair and well kept.

House No. 19, Isidor Nederazof.-House in good condition.

House No. 20, Alexander Merculioff and Zoya Swetzof.-Both portions of house in good condition.

House No. 21, John Merculioff.-House needs to be shingled. Floor all right, except under calidor needing slight repairs. Otherwise in good condition.

House No. 22, Joseph Merculioff.-House in good condition.

House No. 23, George Merculioff.-House in good condition.

House No. 11, Emanuel Zacharoff.-House in good condition.

Recapitulation.-Twenty-four families, 106 souls, live in these houses as above; July $17,1913$.

\section{EXHIBIT E.}

Original signed copy of the testimony of the native sealers on St. Paul Island as to the conduct of sealing by the lessees under the direction of the United States agents since 1890 to date; said testimony being signed by them after it was read from the typed pages to them in Aleut, by the interpreter, George Kochergin, July 25, 1913, and original notes of a public meeting held by the natives, in the town hall of St. Paul Island, Wednesday evening, July 23, 1913, \&-10 p. m., regarding the conduct of the sealing and condition of the seal herd, etc.

Original signed copy.]

QUESTIONS ADDRESSED TO, AND ANSWERED BY, NATIVE SEALERS IN THE MATTER OF SEAL KILLING.

\section{Natives' Town Hall,}

St. Paul Island, Alaska, Thursday, July 24, 1913-8-10 p.m.

Present: Messrs. Henry W. Elliott and A. F. Gallagher, agents of Committee on Expenditures in Department of Commerce, House of Representatives, who called this meeting for this evening.

The following natives were also present: Carp Bouterin, age 60; Peter Oustigof, age 48; Nenn Tetoff, age 43; Porfirio Pankoff, age 50: Peter Tetoff, age 48; Fedosay Sedick, age 67; Elary Stepetin, age 46; Alexander Galaktion of, age 39; and Nicholai Kozloff, age 25; George Kochergin acted as interpreter.

The following questions were put to the natives, through the interpreter, who, in turn, made the following answers on behalf of the natives:

Q. Do vou remember the work of killing of seals in 1890 , when Mr. Elliott tallied it on this island?-A. Yes.

Q. Were you a sealer then?-A. Yes.

Q. Do you remember how all the small seals were turned away and not taken until the last two days of that season's work?-A. Yes; we remember. 
Q. When, after this year, 1890 , did you get orders to kill those small seals-to kill all of them that came in the drives ?-A. In 1896 we commenced to take the 5-pound skins, to the best of our recollection.

Q. Who directed this work of killing the small seals (molodets) on the killing grounds?-A. We do not remember; but J. Stanley Brown was the company's agent at that time.

Q. Did the Government agents object ?-A. We do not remember.

Q. Did the Government agents supervise and tally this killing of small seals at any time from 1894 to 1904 ? - A. Yes.

Q. When the small seals were ordered killed how much blubber was taken with the skins?-A. We got orders to leave some blubber on those skins, and they still have it at this time.

Q. Did you drive and kill seals last summer?-A. Yes.

Q. How large were they?-A. We killed them by ages as we had killed them before. Mr. Lembkey was the Government agent and Mr. George A. Clark was counting the seals. When we were salting skins last year Mr. Clark did not allow us to stretch the skins, as we always have done and do when spreading them in the kench as we salt them. We stretch them out about 2 or 3 inches as we spread them, then put salt on them, and then they shrink back into their natural shape.

Q. How many food seals did you kill last year?-A. Their skins are in the salt house. We do not remember the exact number.

Q. Have you ever driven "holluschickie" (bachelors) from the "laas butschie" (rookeries) ?-A. Carp Booterin says he has not been out for a drive for a long time, but Neon Tetoff says that he went out to drive the seals after Carp's time, and the seals are going close to the cows, because they are getting small.

Q. Did you use whistles to start them out?-A. We used to use whistles, but not lately.

Q. How often have you driven them from the rookeries in this manner?-A. We stopped using whistles about 20 years ago, but we do not know exactly.

Q. Have you ever reported the killing of female seals to the Government agents?-A. When we clubbed the seals we would tell the Government agent, and then the Government agent would tell us to be careful about the cows and not club them.

Q. If so, what did they say?-A. "Be careful and not hit them on the face; not hit the cows." If there were any cows in the pod we used to let them go if we knew it.

Q. Do you remember when the Senators (Dillingham, Nelson, Burnham, and Patterson) came here in 1903 ?-A. Yes.

Q. Were you one of the natives that killed seals for them, to see how you did it?-A. We were all there.

Q. Where did you drive those seals from that (August 3) morning, for this killing to show the Senators?-A. From the reef. We started to kill seals at 5 o'clock in the morning, but we do not remember the time when we had the drive from the reef.

Q. Who directed the work?-A. The Government agents and the company agents. The Government agents were Mr. Lembkey and Mr. Judge, and the company's agents were Mr. Ridpath and Mr. Allis.

Q. After Senator Nelson found three female carcasses which your party had killed, did you look for any more?-A. We did not watch for it. We did not pay attention to it. 
Q. Did the Government agents?-A. We do not know what the Government agents clid.

Q. Have you ever seen a Government agent, since 1S90, look over the killing grounds for female carcasses ? - $\mathrm{A}$. The Government agent has looked for carcasses, as he gave us instructions not to kill the females. At this time, too, we are all looking for them.

Q. Have you ever seen a Government agent examine them ?-A. Yes. Carp Booterin saw then lift them up and examine them. The agent goes through the carcasses and looks for the cows, and when he finds a cow he examines it to make sure of it, and when he finds it is a cow he gives orders to look out for the cows.

Q. When you club a seal or when you skin one, do you know how old it is?-A. We all know it.

Q. Do you ever speak to your fellow workmen about these matters when the day's work is over, as to sizes, ages, numbers, etc., of the seals killed and skinned?-A. Carp Booterin says he used to talk with the other men, but now he has been turning it orer to a younger man. The others all say they talk it orer.

Q. When the "green" or fresh skins are put in salt and then bundled for shipment, are those bundles heavier after salting or lighter?-A. The bundles of skins get hearier, because the salt is inside.

Q. Do those "green" skins ever shrink 4 or 5 or 6 or 8 inches during those four or five days that they harden in salt while in the kenches?-A. Yes; they shrink. When we salt the skins we stretch the skins, and while in the salt they shrink again, about 2 or 3 or 4 inches.

Q. After they come out of the kench to be bundled and while bundling, do they shrink any more?-A. Some of them shrink after they are taken out of the kench and booked, if they are put in the air. Otherwise they do not. Only where the salt does not eatch the skin do they shrink. If they salt all right the skin does not shrink.

\section{Natives' Tows Hall,}

St. Paul Village, Friday, 5.30 p. m., July 25, 1913.

These questions have all been read to us, by Geo. Korchugin, in Aleut, and our answers to them in turn, in Aleut, from this paper, which we sign below, as being our own voice and correct in every particular, to the best of our knowledge and belief.
KARP BUTERIN,
Elary Stepetin, Porfirio Pankoff,
Nichola I Kozloff,
Peter Onstigof,
Alex. Galaktionof,
Peter Tetoff,
FedosaY (his x mark) SEDick,
Neon Tetoff.

St. Paul Island, Alaska,

Village of St. Paul, Town Hall, Friday, July 25, 1913.

The signatures, as above, were all affixed to this paper by the signers, in our presence, after the foregoing questions and answers had been read to these men in Aleut by George Kocherin, from this original typed copy.

Attest:

Henry W. Elliott.

A. F. Gallagher. 
Note.-Confirmatory of the natives' account as above given, that the lessees, after turning away the "small seals" in 1890, attempted to take them all as they drove, is the following order of the Secretary of the Treasury, entered in the Treasury Agent's Journal, St. Paul Island, Wednesday, June $1 \overline{7}, 1896$, p. 14, to wit. This order prevented the lessees then from taking yearling seals. It reads:

\section{Treasury Department, Office of the Secretary,}

Washington, D. C., May 14, 1896.

Mr. J. B. Crowley,

Special Agent in Charge of the Seal Islands.

Sir: I inclose herewith for your information copy of a letter dated the 13th instant, addressed by me to the Secretary of the Treasury, and approved by him, in regard to the taking of fur seals on the Pribilof Islands. * * * The killing of yearlings and seals whose skins weigh less than 6 pounds is prohibited.

Respectfully, yours,

C. S. HamLin, Acting Secretary.

This is the same Mr. Hamlin who, as Assistant Secretary of the Treasury, landed on St. Paul Island August 3, 1894, and became aware of the distinction then as drawn against killing yearlings. He issues this order in 1896, having been informed that the lessees had resolved to get them if they could not fill out their annual quota of 30,000 seals as allowed them in 1896 . This order stopping the taking of small seals by placing the limit at 6 pounds shut out all the yearlings completely, and beyond the power of the lessees' agent to conceal that taking, if he attempted to do so. It shut out the "long yearlings" and the "short" 2-year-olds also. In spite of this order, Dr. Jordan allowed the lessees to kill and take over 8,000 yearlings in 1896.

By some official manipulation the lessees in 1900 were permitted to take "every 5-pound skin that could be found," or every yearling that hauled unless a "runt" and worthless.

This was checked in 1904, May 1, by the "Hitchcock rules," which have not been entered on the official log here, and which have been steadily nullified ever since they were published up to the end of the lessees' killing under their lease, May 1, 1910.

H. W. E.

A. F. G.

Transcript of Stenographic Notes made of

Natives' Statements at a Public Meeting in the Village Hall, St. Paul Village, St. Paul Istand, Alaska, July 2.3, 1913-8 p. m.

Thirty-four of the natives were present at this meeting.

STATEMENT MADE TO THE NATIVES BY MR. ELLIOTT:

Natives and people of St. Paul Island: We have called you to meet us to-night. We have been sent up to these islands by a committee of the United States House of Representatives, charged with the duty of looking into the condition of the seal rookeries, and all other public affairs here, connected with the sealing business.

We are soon to return to Washington, and report to that committee the finding: of fact as we shall get them. 
We want to hear your answers to several questions which we will ask you to make this evening, and we intend to have those answers given to the committee just as you shall give them to us.

(The following questions were asked of the natives at this public meeting in regard to the past condition of the seal herds, and the following replies were given by the natives, through the interpreter, George Kochergin.)

Q. Do you remember the visit to this island of Prof. Elliott in 1890 ?-A. Yes; they do in 1890.

Q. Do you remember the meeting held then in the Treasury agent's house here, which he called for the natives ?-A. Karp Buterin remembers it. Fedosay Sedick also r'emembers it. A number of others say they remember the meeting, but were not present. Sedick is the only man who was present at that time.

Q. Do you remember what the older natives told him then, about the past condition of the fur-seal herd?-A. Karp Buterin says they had not been called at that time to the agent's house and can not remember what the old men said to Prof. Elliott, because they were not there. ${ }^{1}$

Q. Has anybody ever disputed their assertion as to that condition since then, on this island, that you can name?-A. Unable to answer, since they were not present.

Q. When did you last drive seals from "Zapadnie" ?- A. Long ago, in the days of the old Alaska Commercial Co.; not since then.

Q. When did you last drive seals from "English Bay" ?--A. The last drive was made in the days of the North American Commerical Co., but do not know the year, but quite a long time ago.

Q. When dirl you last (lrive seals from "Zoltoi Bluffs" ?-A. Over 10 years ago.

Q. When did you last drive seals from "Polavina"?-A. During the time of the North American Commercial Co.; over 10 years ago.

Q. When did you last drive seals from "Dalnoi" ?-A. About 20 years ago.

Q. When did you last drive seals from "West of Cross IHill"? A. Eighteen or nineteen years ago.

Q. When the orders were given to you in 1900, to take "all of the small seals that could be found," what did the natives say to the Govermment agents? - A. They do not remember.

Q. Have the natives ever been ealled upon to express their views of the condition of this fur-seal herd sinee Prof. Elliot's call to them, in August, 1890 ? - A. Once, in 1906, when Mr. Sims was up here, when the natives asked for a meeting. They told him that the seals were getting small, and also talked to him about the sealing schooners. They say Mr. Sims told them he was on the rookery, looking at the seals, and Sims told them the seals were afraid of him, and just as soon as they saw him all the seals went into the water, and he told the boys to look out for the seals, to take eare of the seals. 'They say' Mr. Sims asked them what the seals were afraid for and went right in the water. They replied that by painting the rocks on the rookeries and counting them and chasing them about, they had gotten afraid.

1 The notes of this 1890 meeting are published in H. Doc. No, 175, 54th Cong., 1st sess., pp. 195-197.

$11864-13$ 
Q. Do you remember the visit of Dr. Jordan to this island in 189697 ? - A. Ýes.

Q. The lessees took every seal that they could get in $1896,30,000$. Did Dr. Jordan supervise that killing on the ground, day after day, as it was done?-A. They did not see him. They saw him once in a while on the killing grounds, but not often.

Q. Was he there on the killing grounds more than a few hours, all told, during the whole season?-A. (See answer to previous question.)

Q. Did he ever watch and tally a killing of scals?-A. (See answer to second last question.)

Q. Who tallied that podding and killing when he was there in 1896-97 ?-A. Only the Government agents.

Q. Was it done at all?-A. They were counted by the Government agents, but they did not see Dr. Jordan do so.

Q. Do you remember when the natives first began to drive the holluschickie off from the rookeries where they had hauled out among the cows? - 1 . They do not remember the year, but they remember that it was when they started to count the seals and the pups upon the rookeries; but before that, they say, they remember that those cows eame among the seals in August.

Q. Did you ever use whistles when you drove those young seals out from the shelter of the rookeries?- - . No. They used to use them, but do not use them now. They just run in and yell and clap their hands. Most of them do not remember that they used them, only the older men.

Q. Did you ever report that work to the Government agents? A. Yes; it was always reported to the Government agents. The Government agents told them to look out and not kill cows. They all know the cows, but they go to drive at 12 o'rlock midnight, when it is dark, and they can not see whether there are cows out among the holluschickie, and that is why they have been taking them. In daytime, when they haul up the holluschickie, if there are cows among them, they separate the cows as much as they can. They did not tell the Government agent that they did not like to do that, but if they drove a cow among the seals they always told the agent of the Government. They say the Government agent told them to look out for that kind of drives. They say they said nothing about that to the Government agent, but the Government agent told them not to make that kind of drives, but to look out for it. They made them because they could not help it, as it was sometimes done in the dark. The chiefs ordered them to make the drives. All those chiefs are now dead. When they were asked to make these drives, they told the Government agents they could not help but take cows, and they also told it to the chiefs, but they did not make the drives where the cows were. Karp Buterin says that the drivers do not go too near to where the cows are. He says those cows were that way when the company was here, and at that time the company did not bother the cows, but when they started counting the seals that caused the cows to get mixed up with the seals.

Q. Who gave you orders to go in among the cows and drive out those small seals-holluchickie?-A. The ehief; and the chief gets his orders from the Government agent, but in the company's time they had been getting orders from the company's agent. 'The'com- 
pany's agent would get permission from the Government agent, and the company agent would give orders to the chief.

Q. In 1890 those natives who did this rookery hustling were paid extra for that work. Was that payment by the lessees continued by them to the end of their lease in 1909?-i. No.

Q. Hare you ever driven seals off from sea Lion Rock so that the company could get them?- 1 . No.

Q. Hare you regularly killed seals on sea Lion Rock every year, and that work done for the company so that it woukd get the skins? A. Just for food, and the skins for the company.

Q. Where have holluschickie ever hauled on the islands where they could not be secured for their skins?-A. There is no such place. They mention one place at Zapadnie, but there are none there now.

Q. Is there a single place on either island where they have ever hauled in which you did not drive them off, if you could not kill them there?-- -1 . There is no such place.

Q. You were ordered to drive the holluschickic off in 1890 , when Prof. Elliott was here-did you st p) that driving at any time since, when the seals hauled out?-A. They used to do it in the time of the Alaska Commercial Company, but not now.

Q. When a pup is newly born, what do you call it (June and July)?-A. A little black piup.

Q. When a pup seal sheds it; black hair, and puts on its gray coat, what clo you call it then (October and November)?-A. A little seal, a gray puip-" cautig."

Q. When the pups all leave the islands here, next November, what if you call them when they come back here next year?

A. small holluschack, small bachelors, or "malinkie holluschickie."

Q. Then when they come back as 2-year olds, the next year, do you call them holluschickie (or bachelors)?-A. Holluschickie or bachelors-2 year olds.

Q. What is a "pol-seccateh," - is it a young .5-year-old male?A. A 5-vear-old.

Q. Why do the eows lay down so close to the surf now, on the rookeries?-A. Because of the counting of them. They can not make them stay in one place.

Q. Do you remember, any of you, how much higher they laid above the surf wash in 1874-1890?-. There were plenty of them. They could not count them. They laid up higher.

$\mathrm{Q}$. When you drive up the holluschickie from near and close to the cows, do you get cows in the drive? - A. (Answered as above.)

Q. Can you tell a 2-year old cow from a 2-year old holluschak?A. They all have the same kind of hair and look alike. It is pretty hard to tell them apart unless they pick them up and handle them.

Q. Do you remember how the skins were "loaded" with blubber, in 1890 ?-A. Karp Buterin says he remembers it.

Q. Have you skinned as much blubber from the seal ever since?A. Yes. They put it on thick ever since.

Q. Do you remember the orders in 1900 when all the little seals were taken for the first time since the company began to take them?-A. They do not remember. They had an epidemic. The old men have died and the young men do not remember. 
Q. Who gave those orders to you-was it the Government agent or the company agent?-A. (See preceding answer.)

(Announcement was made that if the natives wished to ask questions of the representatives of the committee, those questions would be answered.)

The Interpreter. They want to know if the men from Washington got permission to paint the rocks and rookeries and to count the seals. They say they disturb the seals in that way, and they want to know if they have permission to do that.

Mr. ElliotT (through the interpreter). The best answer for me to make is to say that a new administration has taken charge, and that until that administration knows what has been done here, nothing will be done until we get back. That is the reason we are asking these questions, to find out from them what they know of the past work here, and that they can answer these questions without the least hesitation or fear. We have a treaty now with Japan, with Canada, and with Russia which will stop all sealing at sea for fifteen years. We have a law which stops all killing of seals in these islands for the next five years, except that needed for natives' food.

\section{EXHIBIT F.}

Analysis of the sizes and weights of 400 fur-seal skins, taken July 7 , 1913, on St. Pauls Island, under the direction of the United States Bureau of Fisheries; this measurement and weight declares the fact that small skins are systematically "loaded" with blubber, thus giving them weights which conceal their real sizes and ages. The United States Commissioner of Fisheries tells the House Committee that the skins taken by order of the department on the Pribilof Islands are classified as to size and age by their weights on the islands and in London.

Mr. Patron. You mean it is a report that is sworn to by the people who do the selling in London?

Mr. Bowers. No, sir; it is the classification of the London merchants who sell the skins for the United States Government.

Mr. Patton. And they pay on that weight?

Mr. Bowers. They sell on those weights. Their classification is made on those weights.

Mr. ElLiott. Right there I want to interpose the statement that they do not weigh those skins to classify them. They measure them.

(Hearing No. 6, p. 291, July 27, 1911, House Committee on Expenditures in the Department of Commerce and Labor.)

Chief Special Agent Lembkey affirms the same to that committee:

Mr. LembkeY. These skins, which wre sent to London during the years 1909 and 1910 , were weighed by the factors aiter their arrival in London and the weights found to correspond with those taken on the island. As this factor, Lampson \& ro., is essentially a disinterested perscn, being concerned not the least with the question of weights or regulations, but wholly with the sale of the skins and the payments therefor, their verification of these weights may he taken as conclusive of their accuracy.

So far, therefore, as concerns compliance with the regulations and the law in the killing uf male seals, no malfeasance can le proven, because not only the records of the department but the weights of the sane skins in London, taken by an independent and responsible body of experts, prove that the limits of weights laid down by the instructions of the department have been romplied with as closnly as it is possihle for human agency to do so. The weights of skins taken on the islands show thik, 
and futhermore these weights have been verified in London by an imlependent and responsible body of men. (Hearing No. 9, pp. 374, 375, Apr. 13, 1912.)

Mr. LEмвкеу. We have found on the islands that the most reliable way of gauging seal skins so as to classify them into different ages is that of weight. of weighing the skins. Tie have very reliable data showing that 2 -vear-olds seldom, if ever, weigh less than 5 pounds, and we als? have data which gives us the information that the skins of 3 -year-olds weigh from $6 \frac{1}{3}$ to $8 \frac{1}{2}$ pounds. Upon that hasis we have established our regulations. (Hearing No. 9, p 398.)

In re the salt weights and measurements of 400 fur-seal skins taken July 7, 1913, on St. Paul Island, Alaska, and rocorded July 29, 1913.

The following order of procedure was adopted and reduced to writing July 29, 1913, by Messrs. Elliott and Gallagher, agents, House Committee, Expenditures Department of Commeree.

A copy was given to the United States agents in charge of the Seal Islands, Messrs. Chamberlain ${ }^{1}$ and Hatton, who attended and assisted in the work as thus conducted by Messrs. Elliott and Gallagher at the village salt house, St. Paul Island, Tuesday, July 29,1913 , from 9 a. m. till this work was finished at 6 p. m., same day.

Order of procedure in salt house, village of St. Paul, July 29, 1913, which will be followed on the occasion of taking the measurements and salt enred weights of a series of 400 fur-seal skins, secured July 7, 1913, on St. Paul Island.

Said measurements and weights are to be taken by special agents of House Committee on Expenditures in the Department of Commerce, Messrs. Henry W. Elliott and A. F. Gallagher, publicly, in the salt house of the Government July 29, 1913.

First. An interpreter will ask the native sealers to elect four or five of their number to salt and bundle these skins for shipment, as being the men most experieneed, and best workers in salting and bundling sealskins, in the community.

Second. These men are to "spread" these skins aforesaid (and which are duly tagged and numbered with their "green" weights, as taken July 7 last) upon a salter's bench for measurement, one by one, as they are asked to do so by the agents above named.

Third. When those agents have measured them for length, one by one, then those native salters shall proceed to salt and "bundle" these skins (in bundles of 2 skins each) precisely as they have done that work in 1889, under the direction of the agents of the A. C. Co., and since that date under the direction of the agents of the N.A.C. Co. up to 1909. This work of salting and bundling to be done by those native salters aforesaid, without any suggestion or interference from or by anyone during the progress of their work to its finish.

Fourth. When each bundle of two tagged salt skins is duly made by those salters, it will then be weighed and numbered, with that weight duly recorded and publicly announced by said agents at the time of such record and entry.

A copy of the above order of procedure having been duly given to the agents of Bureau of Fisheries in charge of St. Paul Island, Monday evening, July 28, 1913, on Tuesday morning at 9 o'clock

${ }^{1} \mathrm{Mr}$. Chamberlain being ill was duly represented by Messrs. Hatton, Clark, Whitney, and Lembkey. 
following the salt house was opened and the work as above ordered was carried out to the letter; it was finished at $6 \mathrm{p} . \mathrm{m}$.

The following results were obtained, the measurements and weights being all simultaneously made by Messrs. Elliott and Gallagher for the committee, and Messrs. Hatton and Clark and Whitney for the Bureau of Fisheries; evcry figure of weight and measurement being called out at the time it was recorded and made, and agreed to then and there by all parties engaged. Mr. Hatton, for the Burcau of Fisheries, verified every measurement with Mr. Elliott, and agreed upon the same as they were recorded; Mr. Clark and Mr. Whitney, for Fisheries Burcau, rerified every weight with Mr. Gallagher, and agreed upon the same as they were recorded. The following table of recorded salt weights and measurements has been therefore made in complete agreement with the officials in charge of the island, they having a copy of it as it was made on the salter's bench.

The natives selected nine of their best men, who took turns in salting and bundling the skins. No one spoke to them as they did this work, or made a suggestion even as to how they should prepare these skins for shipment in salt.

Each skin has a leather tag strumg to it by one or the other of its flipper holes; on this tag is the number stamped indelibly and so identifies it in the bundles as recorded.

Table shouing the recort and system of recording sulted fur-seal skin measurements and weights which was adopted by Special Agents Elliott and Gallagher in the Government salt house July 29.191.3, when making this record of those green weights and salt weights and mensurenismts of -ion fur-seal stivis taken by order of Bureau of Fisheries on the island of St. Paul, .July $\%, 1913$.

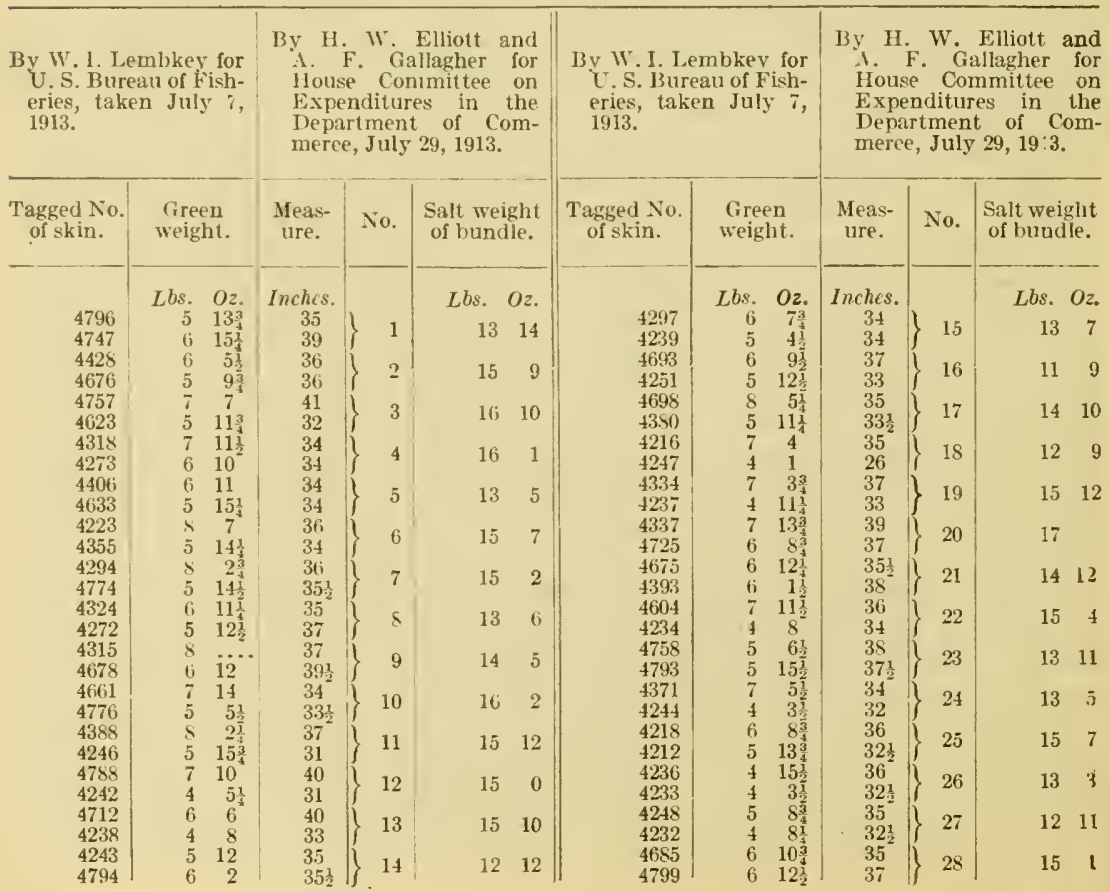


Table showing the record and system of recording salted fur-seal skin measurements and weights which was adopted by Special Agents Elliott. and Gallagher in the Government salt house July 29, 1913, when making this rccord of those green weights and salt weights and measurements of 400 fur-seal skins taken by order of Bureau of Fisheries on the island of St. Paul, July \%, 1919-Continued.

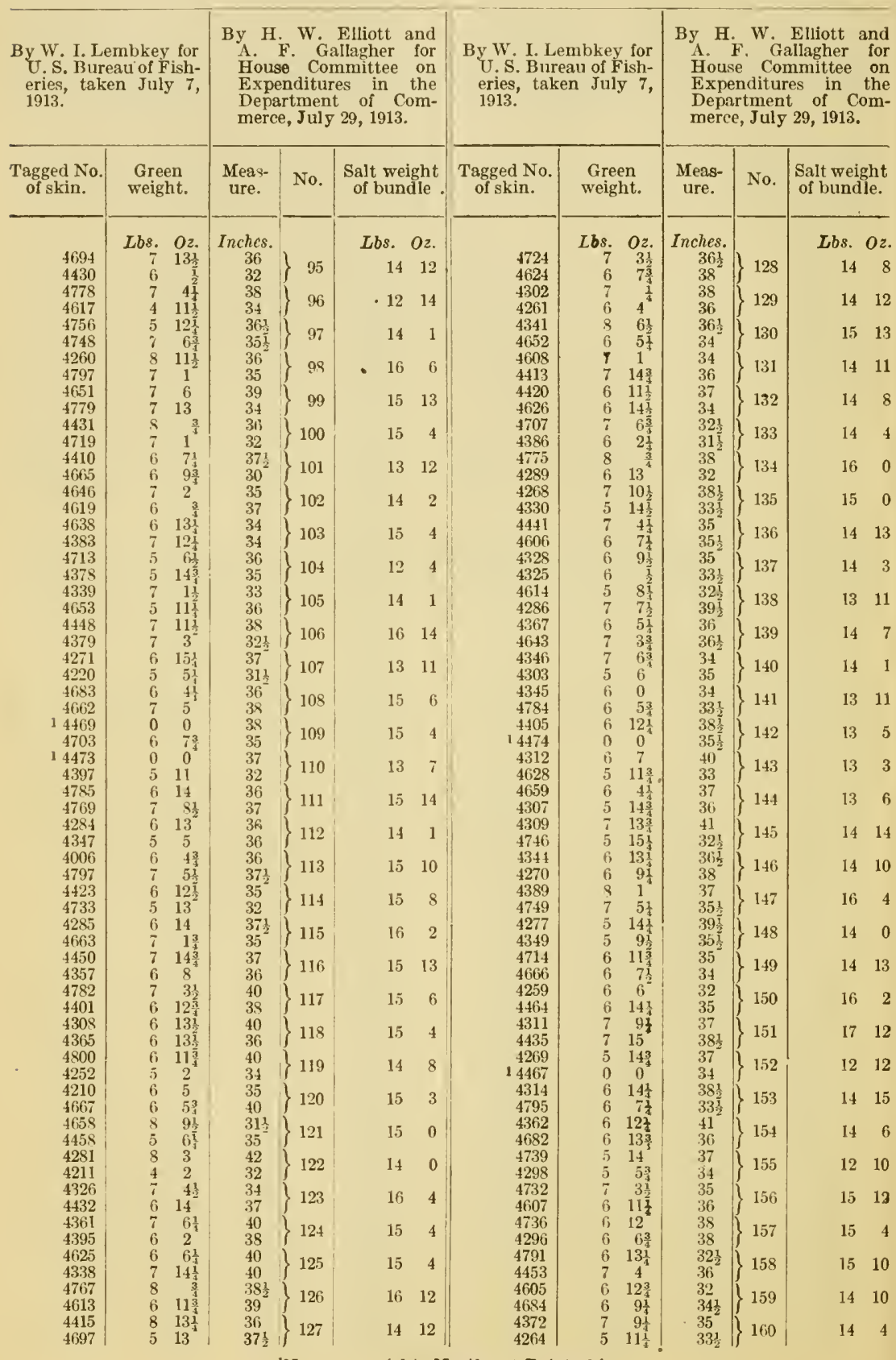

${ }^{1}$ No green weight; Northeast Point skin. 
Table showing the record and system of recording salted fur-seal shin measurements und weights which was adopted by Special Agents Elliott and Gallagher in the Goiernment salt house July 29,1913 , when making this record of those green weights and salt weights aad measurements of 400 fur-seal skins taken by order of Burpau of Fisheries on the island of St. Paul, July \%, 1913-Continued.

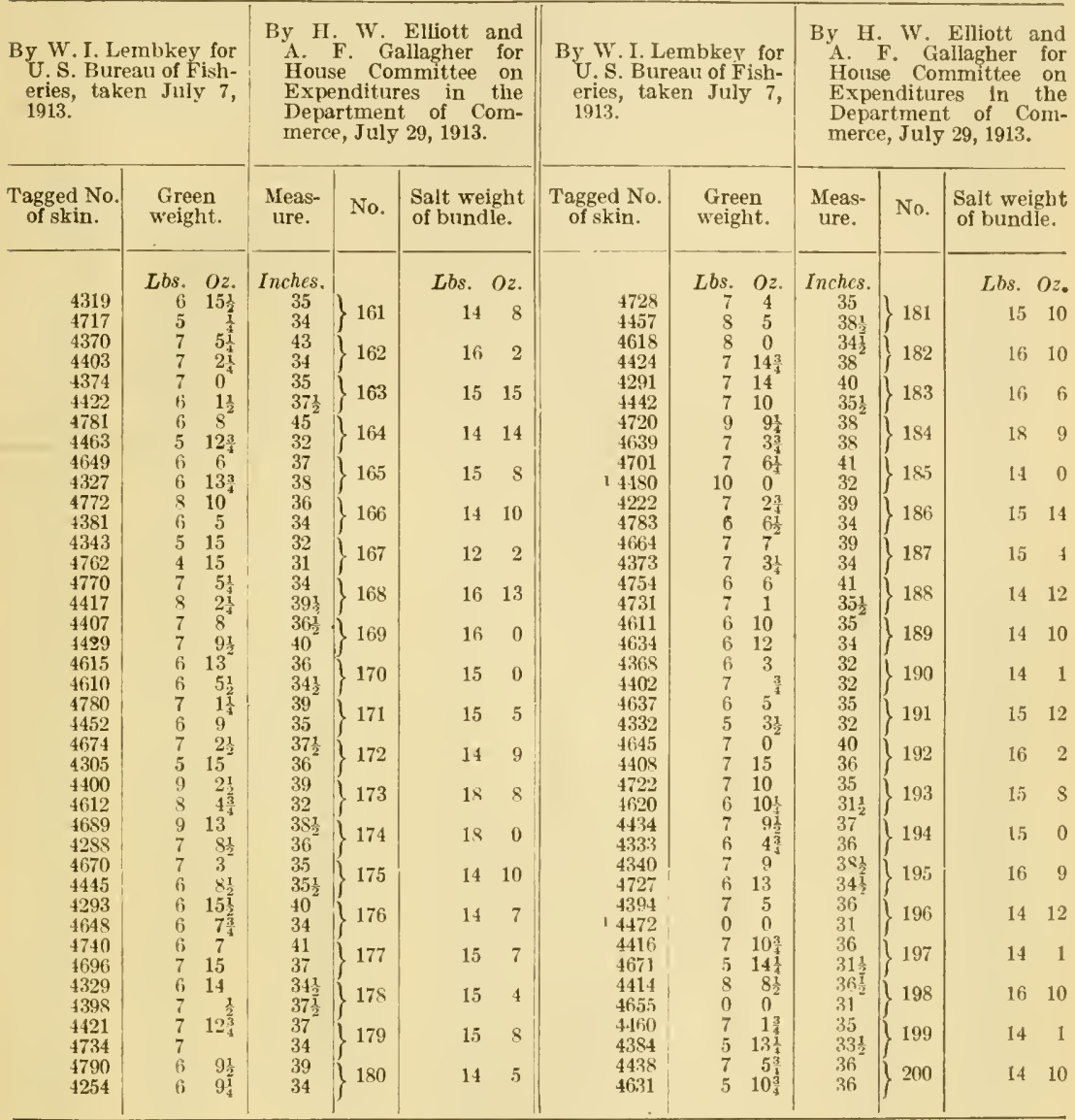

I No green weight; Northeast Point skin.

Note.-The following annotation was made by Walter I. Lombkey on his official record of the weights of the 400 sealskins listed and measured and weighed above, all taken in the killing of July 7 , 1913 :

All seals killed to-day dripping wet, and skins loaded with water. Steady rain, with fog. Southeast wind. To determine percentage of moisture in skins to-day, 12 skins were weighed wet, the moisture then taken from them until the skins were nearly dry, and the same skins weighed again. The aggregate wet weight was 90 pounds 1.5 ounces. The aggregate dry weight was 79 pounds 14.5 ounces; the aggregate loss, 10 pounds 3 ounces, or 11 per cent. All weights to-day, therefore, should be considered as averaging 11 per cent above normal weight.

This statement of Mr. Lembkey orders a decrease of 10 per cent in the green woights, which makes the increased weight of the saltcured skins 10 per cent greater than the figures show. For instance, bundle No. 1 weighs 13 pounds 14 rimees; 10 per cent ofl from the 
green weights makes them 1 pound 3 ounces lighter than they show in Lembkey's table, or the bundle weighs 2 pound more, rather than less.

Analysis of the figures of weight and measurement (taken July 7 , 1913, green, by W. I. Lembkey) made of a series of 400 fur seal skins, which show the loading of small skins so as to make them weigh into larger size skin weights, and so deceive:

30-34 inch yearling skins, which should weigh, if properly skinned, if pounds 8 ounces.

\begin{tabular}{|c|c|c|c|c|c|c|c|c|}
\hline No. & Tag No. & Length. & $\begin{array}{c}\text { Woighed } \\
\text { green } \\
\text { Juy } 7,1913\end{array}$ & No. & Tag No. & Length. & \multicolumn{2}{|c|}{$\begin{array}{c}\text { Weighed } \\
\text { green } \\
\text { July } 7,1913 .\end{array}$} \\
\hline 1 & 4623 & Inches. ${ }_{32}$ & $\begin{array}{rr}\text { Lbs. } & O z \\
5 & 11\end{array}$ & 68 & 4227 & Inches. & $\mathrm{Lbs.}_{4}$ & $\mathrm{Oz}$ \\
\hline $\begin{array}{l}1 \\
2\end{array}$ & 4318 & 3.4 & $\begin{array}{ll}5 & 11 \\
7 & 11\end{array}$ & $\begin{array}{l}08 \\
69\end{array}$ & $\begin{array}{l}4226 \\
4704\end{array}$ & $\begin{array}{l}54 \\
33\end{array}$ & $\begin{array}{l}4 \\
5\end{array}$ & $\begin{array}{l}14 \% \\
10 \frac{1}{2}\end{array}$ \\
\hline$\overline{3}$ & 4273 & 34 & $\begin{array}{ll}5 & 15\end{array}$ & 70 & 4789 & $34 \frac{1}{2}$ & 5 & $15_{4}^{3}$ \\
\hline 4 & 4353 & 34 & $\begin{array}{ll}5 & 14\end{array}$ & 71 & 4301 & $34 \frac{1}{2}$ & 6 & 11 \\
\hline 5 & 4661 & 34 & 714 & 72 & 4716 & $34^{2}$ & 6 & $3 \frac{1}{4}$ \\
\hline 6 & 4246 & 31 & $\begin{array}{ll}5 & 15\end{array}$ & 73 & 4430 & 32 & 6 & \\
\hline 7 & $42+2$ & 31 & $4 \quad 5$ & 74 & 4617 & 34 & 4 & $11 \frac{1}{2}$ \\
\hline 8 & 1238 & 33 & 48 & 75 & 4779 & 34 & 7 & $13^{2}$ \\
\hline 9 & 4297 & 34 & $\begin{array}{ll}67 \\
\end{array}$ & 76 & 4719 & 32 & 7 & 1 \\
\hline 10 & 4239 & 34 & 54 & 77 & 4665 & 30 & 6 & $9_{1}^{3}$ \\
\hline 11 & 4251 & 33 & $\begin{array}{ll}5 & 12\end{array}$ & 75 & 4638 & 34 & 6 & $13 \frac{1}{2}$ \\
\hline 12 & 4380 & $33 \frac{1}{8}$ & $\begin{array}{ll}5 & 11\end{array}$ & 79 & 4.383 & 34 & 7 & $12 \frac{1}{4}$ \\
\hline 13 & +247 & $26^{\circ}$ & 41 & 80 & 4339 & 33 & 7 & 12 \\
\hline 14 & +237 & 33 & $4 \quad 11$ & 81 & 4379 & $32 \frac{1}{2}$ & 7 & 3 \\
\hline 15 & +234 & 34 & 48 & 82 & 4220 & $31 \frac{1}{2}$ & 5 & 51 \\
\hline 16 & 4371 & 34 & 7 & 83 & 4397 & $32^{\circ}$ & 5 & 11 \\
\hline 17 & 4244 & 32 & 43 & $8+1$ & 473.3 & 32 & $j$ & 13 \\
\hline 18 & 4212 & 321 & $\begin{array}{ll}5 & 13\end{array}$ & 85 & 42.52 & 34 & 5 & 2 \\
\hline 19 & +233 & $32 \frac{1}{2}$ & +3 & $8 f$ & 4658 & $31 \frac{1}{2}$ & 8 & $9 \frac{1}{2}$ \\
\hline 20 & +232 & $32 \frac{1}{2}$ & 4 & 87 & 4211 & 32 & 4 & 2 \\
\hline 21 & 4358 & $34^{-}$ & 6 & 88 & 4326 & 34 & 7 & 42 \\
\hline 22 & 4382 & 34 & 6 & 89 & $4(i, 52$ & 34 & 6 & $5 \frac{1}{4}$ \\
\hline 23 & 4241 & 33 & 48 & 90 & 4608 & 34 & 7 & 1 \\
\hline 24 & 4660 & 33 & $\begin{array}{ll}5 & 12\end{array}$ & 91 & 4626 & 34 & 6 & $11 \frac{1}{2}$ \\
\hline 25 & +751 & 32 & 61 & 92 & 4707 & $32 \frac{1}{2}$ & 7 & $0 \frac{3}{4}$ \\
\hline 26 & 4427 & 33 & 6 & 93 & 4386 & $31_{2}^{\frac{1}{2}}$ & 6 & $2 \pi$ \\
\hline 27 & 4715 & 33 & 6 & 94 & $42 \times 9$ & $32^{2}$ & 6 & 13 \\
\hline 28 & 4761 & 34 & 81 & 95 & 4330 & $33 \frac{1}{2}$ & 5 & $14 \frac{1}{2}$ \\
\hline 29 & 4700 & 31 & 5 & 96 & +325 & $33 \frac{1}{2}$ & 6 & $0 \frac{1}{2}$ \\
\hline 30 & 4228 & 34 & 4 & 97 & 4614 & $32 \frac{1}{2}$ & 5 & $8 \frac{1}{2}$ \\
\hline 31 & 4226 & 34 & 5 & 98 & 4346 & $34^{2}$ & 7 & $6 \frac{3}{4}$ \\
\hline 32 & 4673 & 33 & 68 & 99 & 4345 & 34 & 6 & 0 \\
\hline 33 & 4209 & 33 & 6 & 100 & 4784 & $33 \frac{1}{2}$ & 6 & $5 \frac{3}{4}$ \\
\hline 34 & 4240 & 31 & 4 & 101 & 4628 & $33^{2}$ & 5 & $11_{4}^{3}$ \\
\hline 35 & 4356 & 33 & 6 & 102 & 4740 & $32 \frac{1}{2}$ & 5 & $15 \frac{1}{4}$ \\
\hline 36 & 4382 & 34 & $f_{i}$ & 103 & 4666 & $34^{2}$ & 6 & $7 \frac{1}{2}$ \\
\hline 37 & 4241 & 33 & 4 & 104 & 4259 & 32 & i & $6^{2}$ \\
\hline 38 & 4660 & 33 & $\begin{array}{ll}5 & 12\end{array}$ & 105 & $\begin{array}{l}479.5 \\
\end{array}$ & $33 \frac{1}{2}$ & 6 & 71 \\
\hline 39 & 4751 & 32 & $\begin{array}{ll}6 & 1\end{array}$ & 106 & 4298 & $34^{2}$ & 5 & 53 \\
\hline 40 & 4427 & 33 & 6 & 107 & 4791 & $32 \frac{1}{2}$ & 6 & $13 \frac{4}{4}$ \\
\hline 41 & 4715 & 33 & 6 & $10 \mathrm{~s}$ & 4605 & 32 & 6 & $12 \frac{3}{4}$ \\
\hline 42 & 4761 & 34 & 8 & 109 & 4684 & $341_{i}$ & 6 & $9 \frac{1}{4}$ \\
\hline 43 & 4700 & 31 & 5 & 110 & 4264 & $33_{2}^{1}$ & 5 & $11 \frac{1}{4}$ \\
\hline 44 & $422 \mathrm{~s}$ & 34 & 4 & 111 & 4717 & $34^{2}$ & 5 & $0 \frac{1}{4}$ \\
\hline 45 & 4226 & 34 & 5 & 112 & 4403 & 34 & 7 & $2 \frac{1}{3}$ \\
\hline 46 & 4673 & 33 & 6 & 113 & 4463 & 32 & 5 & $12 \frac{3}{4}$ \\
\hline 47 & 4209 & 33 & 6 & 114 & 4381 & 34 & 6 & 5 \\
\hline 48 & 4240 & 31 & 4 & 115 & 4343 & 32 & 5 & 15 \\
\hline 49 & 4356 & 33 & 6 & 116 & +762 & 31 & 4 & 15 \\
\hline 50 & 4224 & 34 & $\begin{array}{lll}6 & 11\end{array}$ & 117 & 4770 & 34 & $i$ & $5 \frac{1}{4}$ \\
\hline 51 & 4249 & 33 & 5 & 118 & 4610 & $34 \frac{1}{2}$ & 6 & $5 \frac{1}{8}$ \\
\hline 52 & +213 & 33 & $\begin{array}{ll}5 & 14\end{array}$ & 119 & 4612 & $32^{2}$ & $x$ & $4 \frac{8}{4}$ \\
\hline 53 & 4275 & 32 & $\begin{array}{ll}8 & 7\end{array}$ & 120 & $46+18$ & 34 & 6 & $7 \frac{3}{4}$ \\
\hline 54 & 4245 & 33 & $\begin{array}{ll}4 & 14\end{array}$ & 121 & 4329 & $34 \frac{1}{2}$ & 6 & 14 \\
\hline 55 & 4258 & 34 & $\begin{array}{ll}5 & 10\end{array}$ & 122 & 4734 & $34^{2}$ & 7 & 0 \\
\hline 56 & 4283 & 34 & 64 & 123 & 4254 & 34 & (i) & $9 \frac{1}{4}$ \\
\hline 57 & 4350 & 33 & $\begin{array}{lll}6 & 12\end{array}$ & 124 & 4618 & $34 \frac{1}{2}$ & 8 & 0 \\
\hline 58 & 4650 & 34 & 610 & 125 & 4783 & 34 & 6 & $6 \frac{1}{2}$ \\
\hline 59 & 4215 & 32 & $\begin{array}{ll}4 & 12\end{array}$ & 126 & 4373 & 34 & 7 & $3 \frac{1}{4}$ \\
\hline 60 & 4225 & 32 & $\begin{array}{ll}4 & 1\end{array}$ & $12 \overline{7}$ & 4634 & 34 & 6 & 12 \\
\hline 61 & 4636 & 34 & 6 & 128 & 4368 & 32 & 6 & 03 \\
\hline 62 & 4266 & 32 & 5 & 129 & 4402 & 32 & 7 & $0 ?$ \\
\hline 63 & 4627 & $32 \frac{1}{2}$ & 7 & 130 & 4332 & 32 & 5 & $3 \frac{1}{2}$ \\
\hline 64 & 4279 & 34 & 63 & 131 & 4620 & $31 \frac{1}{2}$ & 6 & 0 \\
\hline 65 & 4656 & 34 & $\begin{array}{ll}6 & 14\end{array}$ & 132 & 4727 & $34 \frac{1}{2}$ & 6 & 13 \\
\hline 66 & 4690 & $32 \frac{1}{2}$ & 513 & 133 & 4671 & $31 \frac{1}{2}$ & 5 & $14 \frac{1}{2}$ \\
\hline 67 & 4708 & $34^{2}$ & $6 \quad 13$ & 1.34 & 4384 & $33 \frac{2}{2}$ & 5 & 13 즌 \\
\hline
\end{tabular}



Committee au

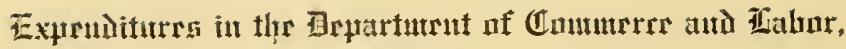

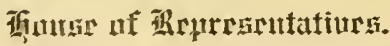

MEMORANDUM.

This letter of bagel puts him up against it - he uses tho so "loaded" skin weights to deceive a senator of che United States, and cactus deny improperly the proof of criminal trespass hike lessees and his on s agate upu the fur seal herd of Olmsted.

That hes had full prion warming of this trespass as early as April 26, 909, is a matter of saros evidence. 
There are 134 skins thus listed above, every one of which is not to exceed $34 \frac{1}{2}$ inches in length. If those small skins had all been properly skinned no one of them would weigh more than 5 pounds, green, and three-fourths of them would not exceed $4 \frac{1}{2}$ pounds. Yet, we find that they all have been so loaded with blubber, when fresh skinned, that with exception of 18 skins they are weighing as much and even more than properly skinned 2-year-old seal's pelts do, and many of them weigh into the 3 -year-old class.

As an instance of that falsification in those weights, above listed, No. 4612 is 32 inches long, and is so blubbered that it weighs 8 pounds $4 \frac{3}{4}$ ounces, and No. 4244 is also only 32 inches long, yet, not blubbered, weighs but 4 pounds $3 \frac{1}{4}$ ounces.

These two yearling skins show beyond dispute that no classification of these skins by weight can be sensibly or honestly made.

The following letter shows the use made of these "loaded" skin weights to deceive. Here they are quoted by the Secretary of Commerce and Labor as proof conclusive that no small seals or yearlings have been taken by his agents:

\section{Department of Commerce and Labor,}

Washington, February $23,1911$.

Hon. Wesley L. Jones,

United States Senate, Washington, D. C

SIR: I have the honor to acknowledge receipt of your letter of the 10 th instant, inclosing a communication to you from Henry W. Elliott relative to the sealskins taken on the Pribilof Islands during the season of 1910 . Mr. Elliott sends you a memorandum giving certain data which he wishes you to believe were taken from the Fur Trade Review for February, 1911, showing that 8,000 skins out of the 12,920 sold in London in December last were taken in violation of the regulations of the department.

For your information, there is appended hereto a statement received from Messrs. Lampson \& Co., of London, dated November 9, 1910, by which firm these skirs were sold, showing the number, weights, and classification as to size of the skins to which Elliot trefers. These weights correspond with those taken on the islands before shipment. The smallest weights reported by Lampson are 4 pounds 10 ounces, of which weight there were only 11 skins. The next smallest weight thus reported was 4 pounds 15 ounces, or within 1 ounce of the size prescribed by the departmental regulations, and these embrace only 81 skins; this immaterial underweight was due to the excessive care of the natives in removing from the skins every vestige of fatty tissue for food. There were thus only 92 skins which, while taken in conformity with law, were under the limit of 5 pounds prescribed by the department, and of these between 70 and 75 per cent were taken for food purposes by the latives after the close of the regular killing season.

When the possibilities of error in judgment as to weight of pelts not yet removed from the seals and of unavoidable accidents incident to the killing of thousands of animals are considered, the wonder is that there are so few undersized animals killed. 'The results indicate careful supervision by the agents and also accuracy on the part of the clubbers.

The law forbids the killing of seals less than 1 year old except when necessary to secure food for the natives. This necessity did not arise in 1910, and, consequently, no seals under 1 year old were killed in that year.

Respectfully,

(harles Nagel, Secretary.

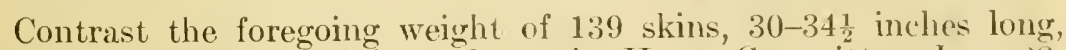
with the following exhibit made to the House Committee, June 2S, 1911 , and the folly and error of this attempt of the United States Commissioner of Fisheries to deceive the committee will be at once apparent.

The Bureau of Fisheries improperly classifies the skins by weight, and the following sworn statement proves it that a yearling skin 
(30-34 inches long) weighs $4 \frac{1}{2}$ pounds, properly skinned is used as the basis of this classification:

Mr. Townsend. I will examine you now as to the killing of seals after the expiration of this lease and when the killing was made, as it has been called here by the Goverument. The report shows that in the year $1910,12,920$ seals were killed, and the evidence before the committee is that of those 8,000 were yearlings.

Mr. Bowers. Well, that evidence is false.

Mr. Townsend. That is your answer to that, is it?

Mr. Bowers. Yes, sir. Here are the weights on the basis, you understand, that a $4 \frac{1}{2}$-pound skin is a yearling. There are the weights for 1909 , the island weights and the London weights. I think probably you will find one skin weighing less than $4 \frac{1}{2}$ pounds.

C. M. Lampson \& Co., London, November 19, 1910.

Assortment of Alaska salted fur sealskins for account of United States Government Department of Commerce and Labor.

[New York, Ck. 1/228.]

Lbs. Ozs.

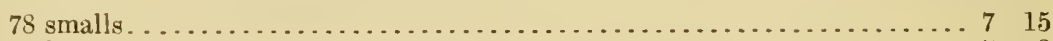

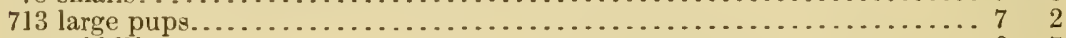

3,032 middling pups. . . . . . . . . . . . . . . . . . . . . . . . . . . . . . 6 . 7

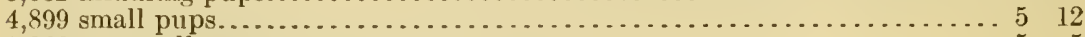

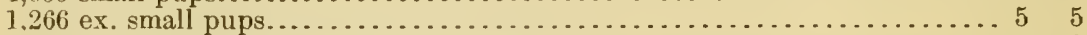

11 ex. ex. small pups...................................... 40

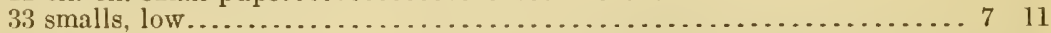

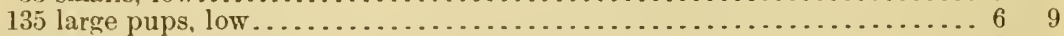

498 middling pups, low . . . . . . . . . . . . . . . . . . . . . . . . . . $6 . \ldots \ldots$

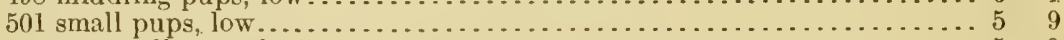

88 ex. small pups, low ................................... 5 . 0

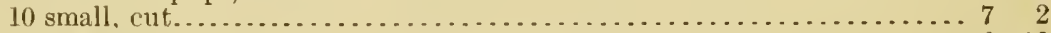

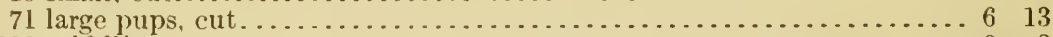

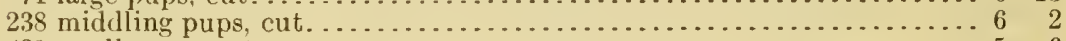

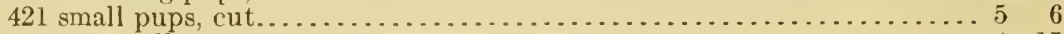

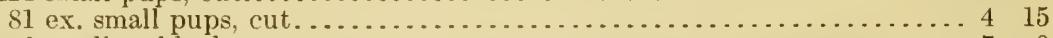

6 sinall, rubbed....................................... 7 . 0

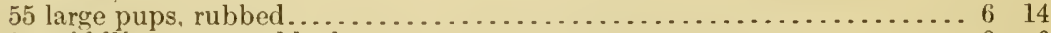

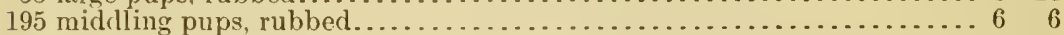

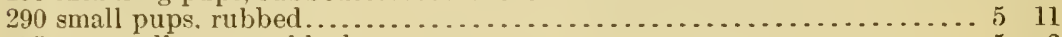

75 ex. small pups, rubbed.................................. 5 . 3

36 faulty.

12,732 average based on December, 1909, prices 144/.

5 small.

21 large pups.

45 middling pups.

94 small pups.

18 ex. small pups.

2 faulty.

188 average hased on December, 1909, prices 120 .

12,920

Subject to recount.

Mr. Elloto. Right at this point-
Mr. Townsend (interposing). Do youl refer to 1910 or 1909 ? Is that 1909 ?

Mr. Bowers. No; this is 1910 . (Hearing No. 3, p. 128.)

In order to justify that killing of more than 7,733 yearlings in 1910, as admitted by W. I. Lembkey, under oath, April 13, 1912, Dr. Jordan's man, Geo. W. Clark, prepared and published February 28, 1913, an elaborate and studied statement in which he declares that these weights (those "loaded" blubbered skins which he and 
his scientific associates have been familiar with since 1896), properly deny the charge that yearlings were so killed.

This exhibition of those "loaded" skins-those blubbered 30-34 inch skins (7,733 of them), taken in 1910, Clark unwittingly makes in Science, issue of February 28, 1913, pages 325-327. He goes farther: With the cooperation of Dr. D. S. Jordan he has a reprint of these pages from Science made, and sends a copy to every Senator and Member of Congress, in which he uses these bogus "loaded" skin weights to deny the killing of those small seals, which have as above been admitted so killed by his own associate and confederate, W. I. Lembkey.

He says:

On the other hand, the testimony clearly shows that of the 13,500 skins taken in 1910 (of which 12,920 were sold in London in December of that year), the season under particular consideration, only 90 were under the standard weight of the 2 -year-old, as shown by the green weights taken by the agents on the islands, and only 92 by the salted weights of the London fur dealers.

Turn from this statement, as quoted from Clark, to that exhibit of 400 skins which were taken July 7 , last, just as these skins of 1910 were taken, and by the same men, under the same director, W. I. Lembkey.

According to the green weights which those 400 blubbered skins show, there are only 18 skins under Clark's "standard weight of the 2-year-old"-only is yearlings.

Yet the fact is that there are in this small list of 400 sealskins, taken in the very best season of the year, and when the largest seals are most plentiful at any one time of the year, there are actually 139 yearling skins, every one of them less than $34 \frac{1}{2}$ inches long. T et every one of these little skins has been so "loaded" with blubber that they weigh into the classes of 2 and 3 year old skins.

Why does Dr. Jordan (and Mr. Clark also) ignore the measurements of those skins? Those measurements of that 12,920 skins show bevond a shadow of dispute that 7,733 of them were each less than 34 inches long-show that they were yearling seals' skins.

No one of the scientists of the advisory board on fur seal service, of which Dr. Jordan is the president, has dared to publicly deny the admission made by their own confederate, W. I. Lembkey, that the skin of a yearling seal is $36 \frac{1}{2}$ inches long, just as has been said by Mr. Elliott, who has testified as follows:

Mr. Lembkey thus testifies that his own summary and official record of the measurements of "7,733 fur sealskins," which he took during the season of 1910 on the Pribilof Islands, declares the fact that no one of them exceeds in length 34 inches. That fact determines them-all of them-to have been the skins taken from yearling seals--

Mr. Madden. Let me ask you a question. According to Mr. Lembkey's testimony read by you, he testified that the lengtli of a yearling would be $39 \frac{1}{2}$ inches, and when it was skinned the skin itself would be 36 inches. Does it always follow that a yearling seal measures just the same or within an inch or two of the same length?

Ifr. Ellotr. I think the range is about 3 to 4 inches; a small yearling skin goes 30 inches, a good average yearling skin 34 inches, and a "long" yearling 36 inches. There are three grades.

Mr. MaDDEN. All seals are not of the same size?

Mr. ELLIOTT. No; but there is the general average, and you can very easily keep within the limit.

Mr. MADDEN. As a matter of fact, you might possibly find a seal that was returned a year old, and after it liad come back from its trip to the ocean on the 25 th of July it would be a year or a few days over, and it might not be over 30 inches in length?

Mr. Elliott. Yes, sir. 
Mr. MAdDen. And it might be $39 \frac{1}{3}$ inches?

Mr. ElizotT. Thirty-six inches. Mr. Lembkey, when he measured what he called a "yearling," selected a remarkably well-grown one. I allowed him to take those as "middling pups," and I have not charged any malfeasance in having those so taken by him. Those "long" yearlings are invariably males, and no real risk of killing females, when he does, is incurred by him. (Hearing No. 14, pp. 905-906, July 30, 1912, Honse Committee on Expenditures Department of Commerce and Labor.)

The following weights of the large 39-43 incl skins, taken .July 7 , 1913, show that they have been "clean skimned," not "blubbered," and show the fair size per salt weight of skin. They are 3-year-old skins, yet in Lembkey's list a large number of these small 30-3t inch skins weigh just as much as these $39-43$-inch skins $(l o$, as shown in the foregoing abstract and below, to wit:

\begin{tabular}{|c|c|c|c|c|c|c|c|c|c|}
\hline \multirow[t]{2}{*}{ No. } & \multirow[t]{2}{*}{ Tag No. } & \multirow{2}{*}{$\begin{array}{l}\text { Length. } \\
\text { Inches. }\end{array}$} & \multicolumn{2}{|c|}{$\begin{array}{c}\text { Weighed } \\
\text { green } \\
\text { July } \tau, 1913 .\end{array}$} & \multirow[t]{2}{*}{ No. } & Tag No. & length. & \multicolumn{2}{|c|}{$\begin{array}{c}\text { Weighed } \\
\text { green } \\
\text { July } 7,1913 .\end{array}$} \\
\hline & & & $L b s$. & $O=$. & & & Incles. & $L b s$. & \\
\hline $\begin{array}{l}1 \\
2\end{array}$ & $\begin{array}{l}4757 \\
4788\end{array}$ & $\begin{array}{l}41 \\
40\end{array}$ & $\frac{7}{1}$ & $\begin{array}{r}7 \\
10\end{array}$ & $\begin{array}{l}21 \\
22\end{array}$ & $\begin{array}{l}4625 \\
4338\end{array}$ & $\begin{array}{l}40 \\
40\end{array}$ & $\begin{array}{l}6 \\
7\end{array}$ & $\begin{array}{r}64 \\
14\end{array}$ \\
\hline 3 & $\begin{array}{l}4712\end{array}$ & 40) & ij & 6 & 23 & $42 \times 6$ & $39 \frac{1}{3}$ & 7 & $7 \frac{1}{2}$ \\
\hline 4 & 4723 & 39 & 7 & $8 \frac{1}{2}$ & 24 & 4312 & $40^{\circ}$ & 6 & 7 \\
\hline 5 & 4705 & $42 \frac{1}{2}$ & $i$ & $33_{1}^{\bar{\tau}}$ & 25 & 4309 & 41 & 7 & 133 \\
\hline 6 & 4709 & 40) & $s$ & $5 \frac{1}{1}$ & 26 & +277 & 39.1 & 5 & 14 \\
\hline 7 & $476 \mathrm{~S}$ & 39 & 7 & 5. & 27 & 4362 & $41^{2}$ & 6 & 121 \\
\hline 8 & 4766 & 39 & 5 & 9 & 28 & 4781 & 45 & f & 8 \\
\hline 9 & 4706 & 39 & 6. & $10)^{3}$ & 29 & 4417 & $39 !$ & S & $2 !$ \\
\hline 10 & $43 f 4$ & 39 & 6 & $7 \frac{1}{2}$ & 30 & $\begin{array}{r}4429 \\
\end{array}$ & $40^{\circ}$ & 7 & $9 \sqrt{3}$ \\
\hline 11 & 4711 & 44 & 8 & $6^{2}$ & 31 & $47 \times 0$ & 39 & 7 & 14 \\
\hline 12 & 4755 & 40 & 6 & 11) & 32 & 4400 & 39 & 9 & 21 \\
\hline 13 & 4274 & $39 \frac{1}{2}$ & 8 & $0^{\circ}$ & 33 & 4293 & 40 & 6 & $15 \frac{1}{2}$ \\
\hline 14 & 46.51 & $39^{\circ}$ & 7 & 6 & 34 & 4291 & 40 & 7 & 14 \\
\hline 15 & 472 & 40 & 7 & $3 \frac{1}{2}$ & 35 & 4701 & 41 & 7 & 6 \\
\hline 16 & 4308 & 40 & 6 & $13 \frac{\pi}{3}$ & 36 & 4222 & 39 & 7 & 23 \\
\hline 17 & 4800 & 40 & if & $11_{4}^{3}$ & 37 & 4664 & 39 & 7 & 7 \\
\hline 18 & 4667 & 40 & 6 & $5_{4}^{3}$ & 38 & 4754 & 41 & 6 & 6 \\
\hline 19 & 4281 & 42 & $x$ & 3 & 39 & 4645 & 40 & 7 & 0 \\
\hline 20 & 4361 & 10 & 7 & (i) & & & & & \\
\hline
\end{tabular}

Here are 39 skins, which are each between 39-43 inches long, and are clearly the skins of 3 -year-olds. They were skinned at the same time on the same field that the yearling $30-34$ inch skins were. Yet 53 of those small yearling $30-34$ inch skins are so loarled with blubber that they each one weigh as much as any one of those big $39-43$ inch skins do.

The 2-rear-old $36 \frac{1}{2}-38$-inch skins in this list of 400 skins, as above cited, are not so heavily loaded, but nearly all of them are so put up into the 3 -vear-old weights, viz, 7 pounds and up to $8 \frac{1}{2}$ pounds. There are 127 of these loaded 2-vear-olds in this exhibit of 400 . These green weights of those skins should run from $5 \frac{1}{2}$ pounds to 6 pounds each, if properly skinned; never any less.

This showing of those 400 .July 7, 1913, green skins declares the fact-

I. That the small 30-34-inch skins have nearly all of them been loaded with blubber so as to weigh into the 2 and 3 year old class of skin weights, i. e., into the same weights that belong to properly skinned $36 \frac{1}{2}-38$ and $39-44$ inch skins.

II. That weight list of Lembkey thus falsely certifies 139 yearling skins by this record of killing of July 7, 1913, "as the skins of seals not under 2 years of age." 
III. That weight list of Lembkey is the certified proof of this illegal killing, and it shows exactly how this work of loading the green skins with blubber so as to deceive as to (weight of) size of skin ever since 1896 - how it has been done on the islands by the lessees with the aid of the agents of the Government, year after year, since then, up to date.

Mr. Young. In this hearing, volume 3, page 131, there seems to be a statement or a report sent out by the London agent, clated the 19th of November, 1910, as to the salted fur-seal skins for the account of the United States Government. That statement seems to be arranged altogether on the basis of weights.

Mr. Elliotr. But that is simply in response to an inquiry from the bureau. They do not classify them according to the bureau's direction. They classify these skins by measurement. The bureau asked for the weights, and they sent them the weights; but they do not classify them by weights. They would be laughed out of court and would lose their standing if they undertook to classify them by weight. You never know what skinners and salters will do with the weights, but they can not trifle with the measurements. They can not change the measurements; but the $y$ can "load" them with weight of blubber and salt anywhere from $1 \frac{1}{2}$ to 3 pounds. I have seen it done. Did I not see this man, in 1890, grin and smile about how he was fixing his skins to increase their weight; but the langh was on him when the Lampson's returns came in. (Hearing No. 4, p. 223, July 11, 1911. House Committee on Expenditures, Department of Commerce and Labor.)

Lembkey swears that the skin of a yearling fur seal is $36 \frac{1}{2}$ inches long, to wit.

Mr. EцLioti. Mr. Lembkey, do you know the length of a yearling seal from its nose to the tip of its tail?

Mr. LEMBKEY. No, sir, not off-hand.

Mr. EцLIOTt. You never measured one?

Mr. LEM веу. Oh, yes, I have measured one.

Mr. Elliott. Have you no record of it?

MIr. LEMBKEY. I have a record of it here.

Mr. ElliotT. What is its length?

Mr. LEnвкEY. The length of a yearling seal on the animal would be, from the tip of the nose to the root of the tail, $39 \frac{1}{2}$ inches in one instance and $39 \frac{1}{2}$ in another instance.

Mr. ЕцLiotт. Yes.

Mr. LEMBKEY. And 41 in another instance. I measured only three.

Mr. Elliott. Yes.

Mr. LenвкеY. All right.

Mr. ElliotT. When you take a skin off of that yearling seal, how much of that skin do you leave on there?

Mr. LEMBKEY. You do not leave very much on the tail end there [indicating]; not nearly so much as your sketch would show.

Mr. ElizotT. It does not matter.

Mr. LEMB KEY. We leave about 3 inches, perhaps, on the head.

Mr. Elliot . How much can you say is left on a yearling after you have taken the skin off?

The Chasman. How much skin is left after you have taken it off?

Mr. ElLiotT. Yes, sir; after they remove it for commercial purposes a certain amount is left on.

Mr. LeMBKEY. I stated about 3 inclies.

Mr. EuLOTt. Then that wonld leave a yearling skin to be 35 inches long.

Mr. LEмвKEY. No; if it was $39 \frac{1}{2}$ inches long it would leave it $36 \frac{1}{2}$ inches. That is, all the animal from the tip of the nose to the root of the tail would be 392 inclies long. Three inches off that would leave $36 \frac{1}{2}$ inches. (Hearing No. 9, pp. 442, 443, Apr. 13. 1912. House Committee on Expenditures, Department of Commerce and C.abor.)

Out of the foregoing exhibit of 400 skins taken by Mr. Lembkey, July $7,1913,261$ of them are not over $36 \frac{1}{2}$ inches in length, or are yearling skins of his identification and measurement? 
THE DEADLY PARALLEL

Lembkey tells the truth in 1904, and records the fact that salting seal skins increases their weight.

Chief Special Agent Lembkey makes the following entry on page 149 of the Journal of the Government Agent on St. Pauls Island, Alaska, to wit-

"SATURDAY, July 23, 1904.

"One hundred and seven skins taken on Tolstoi were weighed and salted. To-day they were hauled out of the trench and reweighed. At the time of killing they weighted 705 pounds, and on being taken out they weighed $759 \frac{1}{2}$ pounds, a gain in salting of $54 \frac{1}{2}$ pounds, or one-half pound per skin."

A true copy, made July 22, 1913.

Attest: HenRy H. ElliotT,

A. F. Gallagher,

Agents House Committee on Expenditures in the Department of Commerce.

But Lembkey falls from truth abovefalls hard.

[Hearing No. 9, p. 446, A pr. 13, 1912, House Committee on Expenditure in the Department of Commerce and Labor.]

Mr. Elliotr. Mr. Lembkey, you say you never have weighed these skins after you have salted them? You have never weighed them?

Mr. LemBkey. I have never weighed them after the salting on the islands; no, sir.
Lembkey tells an untruth in 1912 , and so does under oath, to shield and deny his illegal killing of yearling seals.

[Hearing |No. 9, pp. 445-446, Apr. 13, 1912, Ilouse Committee on Expenditure in the Department of Commeree and Labor.]

Mr. Lemi кеy. No, sir. I speak of the weights on the islands, and have brought in the London weights to show there is not really very much variation.

Mr. MicGuine. That is what I am speaking about. The weights you speak about after salting are the London weights?

Mr.LeMB KEY. Yes, sir.

Mr. McGuire. That is what I was trying to get at. Now, then, Mr. Elliott, what weights do you speak about?

Mr. Elliotr. I speak of the London "salt weights" increasing the "green weights" on the islands one-half pound and more, as the skins vary in size.

Mr. McGuire. You speak of the green weights in London aiter they have been salted?

Mr. Elimott. Yes, sir.

Mr. McGuire. And Mr. Lembkey spoke of the weights in London after they lave been salted.

Mr. Elliottr. We are both speaking of the same thing.

Mr. McGuire. You say there is a slight decrease?-no-You say, Mr. Elliott, there is an increase from a fraction of a pound to a pound, even in London?

Mr. Eillotr. Even in London. I wish to quote as my authority the man who does the classifications in London, Sir George Baden-Powell, and Dr. George M. Dawson, the British commissioner, addressed a letter to Sir Curtis Lampson.

The Chalrman. What do they say?

Mr. Elliott. They say:

"We are unable to answer your inquiry as to what class the sales catalogue would place a skin classified on the island as, say, a 7-pound skin, as we do not know whether the classification you mention with reference to the skins is taken after _... or after they have been cured and salted ready for shipping. The process of curing and salting must of necessity add to the weight.

Mr. Lembkey. "Must of necessity." I submit that was merely his inference that they must of necessity be increased in weight.

The Chairman. Is that not true?

Mr. LeMbKey. No, I stated it was not

The Chairman. You differ on that?

Mr. LEMBKEY. All our experiments show that the salting of skins slightly decrease the weight. Those gentlemen's inference and I think the inference of a great many people who have never made 
an experiment on that point-would be that the salt, does increase it.

The ("halkman. Are these gentlemen qualified in your opinion to pass judgment on that question?

Mr. Elliott. The Lampsons?

Mr. Lembiex. I should like to have had Sir Curtis Lampson, or whoever this man is, make some practical experiments with regard to variations in weight, and not simply give lis opinion.

The Chairman. There seems to be a difference there in opinion on a very important matter.

Dr. Evermann. May l say just a word?

The ('Halruan. Yes.

Dr. Everuans. This statement that Mr. Elliott has read gives the opinion of that gentlemen as to the effect of salt. He does not claim to have weighed any skins green, and then subsequently weighed those skins after having been salted to determine the effect.

\section{Deceit practiced by Bureau of Fisheries to conceal the illegal killing of small seals on Pribilof Islands.}

The Deceit and Trick.

The salt is all removed from skins hefore weighing, so as to show that the "salt weights" are less than the "green" weights.

Dr. Everuann. Last year, when Mr. M. C. Marsh, naturalist, fur-seal service, went to the Pribilof Islands, he was instructed to make certain. investigations. one of which was to determine by actual experiment the efiect that salting has 11 pon the weight of fur-seal skins. He made a very careful investigation of the matter, and his report has just been received. It is so interesting and valuable that I wish to put it in the record. His investigation settles the question conclusively and for all time. It shows that salting causes fur-seal skins to lose weight. The report is as follows:

The average loss of weight for the whole 60 skins is 0.63 pound. or 10 ounces. This is an nuderstatement of the average loss of weight, which, I believe, is at least an ounce greater. The reason is that it is practically impossible to mechanically remove all the salt from the skins before reweighing. They were shaken, swept, and brushed, but a few grains and crystals of salt were always left adhering to each side of tle skin. Obvionsly it would not do to wash them off. By more carefully cleanizg a few of the reweighed stins and then again weighing them. I estimate this residual salt to average all ounce or something more.

\section{The Deceit Exposed.}

The salt and skins are weighed together in the London classification-that increases the "green skin" weights.

Mr. Elliots. Now, in Senate Executive Document No. 177, Fifty-third Congress, second session, pages 117 and 118 [Senate Executive Document, 177, pt. 7], counter case of the United States, on page 118 the United States commissioners, Merriam and Mendenhall, have this to say toucling the salted weights:

"The British commissioners further rely upon Mr. Elliott's statement that skins weigh from $5 \frac{1}{2}$ pounds to 12 pounds (sec. 672), and upon the comparison of such statement with that of Lieut. Maynard, an independent observer, who gives the average weight of biundles as 22 pounds and the weight of the largest as 64 pounds (see. 672). This appears to the commissioners to require some explanation (sec. 673). The implication is evident, and the United States offer the explanation in vindication of the officers of the Government who are thus charged. A bundle contains mot only the two skins proper. but salt and blubber with which they are packed for their preservation. This naturally adds greatly to the weight, as does also the moisture collected by the salt and fur."

That sustains me completely about the increased weight of "green" skins after they are cured on the islinds and our Government carried that claim as a voucher 
The careful identification of every skin and the care given to every detail of the weighing make it quite certain that the salting of sealskins as practiced on St. Paul Islaud subtracts materially from its original weight when freshly skinned. Presumably, though not necessarily, the London weights reported are less than the actual weights of the skins at the island killings. If any change takes place during transportation to London, it is likely to be a further loss. Ilearing No. 14, pp. 974, 975, July 29. 1912.)

to Paris. It was never disputed by either side at those sessions of the Bering Sea Tribunal, held there from April to August, 1893.

Dr. Everainn. I would like the cliairman to ask Mr. Elliott to tell the committee on what skins the statement he just read was based.

Mr. Ellioto. It is in the report of Lieut. Maynard. It is there, and is cited in the communication of the commissioners

The CHAlruAN. That is your answer-

Mr. Elinotr. And the report of Lieut. Maynard is in my monograple, and I will go right to the page if you want it (pp. 106107, Elliott's Monograph Seal Islands, Tenth Census, United States of America, Washington, 1854). (Hearing No. 14, p. 995 , July 29, 1912.)

In the foregoing statements we have made'an exhibition of 400 skins which were taken (as they have been loaded by the lessees since 1890), July 7, 1913, on St. Paul Island; they are all now tagged, numbered, and recorded as to salt and green weights and measurements.

In the light of the exposé which they give it is interesting to regard the following testimony, at the outset, to wit:

[Hearing No. 10, p. 566, Apr. 24, 1912, Ilouse Committee on Expenditures in the Department of Commerce and Labor.]

Dr. Evermans. On page 222 of these hearings Mr. Elliott says that, in arriving at his estimates of the numbers of yearling seals taken as set forth in the table submitted by him, and printed on page 220 , he was guided "solely by measurements. The weights do not amount to any thing," he says. The London people would be the biggest fools in the world, he says, to go by weights. And he shows how foolish it would be for the killers on the islands to leave an extra amount of blubber on the skin. Ile says that when he pointed out to the people on the islands that the skins in London were classified by measurement rather than by weight they quit blubbering them. (P. 222.)

Mr. Elloto They didn't quit blubbering them; they kept on.

Dr. Evermann. Then that statement is not true?

Mr. Ellotot. I said they might quit it; but they did not; they kept right on, and they are still at it, very clearly.

Dr. Evermann. On page 223 Mr. Elliott states specifically that the skins are classified in London entirely by measurements not by weights.

Mr. ELLIOTT. I do now.

[Hearing No. 9, p. 406, Feb. 29, 1912.]

Mr. LEMBKEY. There are five different weights given by Mr. Elliott, and I have compared them in this statement.

Mr. MADDEN. Let us clear it up right here, if we can, without any prejudice. I would like to ask Mr. Elliott a question if I may be allowed to, Mr. Chairman, just to clear up this. I understood Mr. Lembkey to testify that Mr. Elliott claimed that a seal of a certain age, a sealskin of a certain weight, would indicate the seal's age. For example, in his official reports, he said a certain aged seal would have a skin weighing $4 \frac{1}{2}$ pounds, and that a certain other aged seal would have a skin weighing $5 \frac{1}{2}$ pounds, and that later on Mr. Elliott had stated that these skins varied from 6 to 7 pounds. Now, I understood Mr. Elliott to say, and I want to get it correct in the record so as to do justice to Mr. Elliott, as well as to Mr. Lembkey, that when he makes the statement of 6 to 7 pounds that he means the salted skins.

Mr. Elliotot. Yes, with more or less blubber and salt per skin.

Mr. MADDEN. And in the case where he makes the flat statement of $4 \frac{1}{2}$ to 5 pounds, it is a green skin.

Mr. Eı.LIOTT. A "green skin," and that creates all these differences. 
Mr. MADDEN. I wanted to straighten that up so there would not be any misunderstanding about it. I think it is only fair to all sides.

Mr. ElLIотт. My official tables are all "green" weights. Interpreting the London tables, I take salt weights and keep the London measurements corresponding with the official record of measurements made on the islands.

Mr. MADDEN. Your idea is the salt weight of the skins would vary $1 \frac{1}{2}$ pounds?

Mr. ElLrott. One and one-half pounds according to blubber and salt.

Mr. MADDEN. Only green skins.

Mr. Elliotr. Yes, sir; and the London agent says so.

Mr. MADDEn. So, as a matter of fact, if in the one case it was stated by Mr. Elliott a skin would be $4 \frac{1}{2}$ pounds, and another case $5 \frac{1}{2}$ pounds, and later on 6 and 7 pounds, that it was mderstood that one was green and another salt, then his statements in both cases would be correct?

Mr. Ellotr. Yes; all the time bear in mind that the weights were uneliable, and the measurements only, reliable, all through my testimony.

The Chairman. Did Mr. Lembkey understand it in that way?

Mr. LeмвкEY. I certainly did not. I stated I wals very much confused in encountering the different weights for these different classes of skins.

Mr. IlctillicudDy. I think you will find he takes up that matter of blubber and salt.

Lembkey, finally cornered, admitted that the London classification ignored his weight of skins, then attempts to deny his understanding.

[Hearing No. 9, p. 447.]

Mr. I, EmbКеy. Yes, the blubber would.

Mr. Elıots. Ill that can be done, can it not?

Mr. L.EMBKEY. I might state here, while you are on that point, that it would not alter except in perhaps a very slight degree the classification of that skin when it was received in London by the factors.

Mr. Elliott. Certainly.

Mr. LenBKEY. You might make a yearling skin weigh 9 pounds by the adding of blubber, yet when it got to London it would he only so long and so wide.

Mr. Eliotot. That is it.

Mr. LenвkEy. And of course it would develop in the rlassification when the skins would be exposed for sale.

The Chairman. Do you mean by that that you rely when it gets to I ondon on the measurement rather than on the weight?

Mr. LemBKEY. Ne do not have anything to do with this classification.

The Chamman. I know, but somebody does.

Mr. LEMBKEY. Mr. Ellintt is making the point-

The CuAruas. You have just said that no matter how much blubber there was on it it would not alter the lengeh and width.

Mr. Lembrex. Certainly not.

The Charmas. Then do your rely upon the length and width of it rather than on the weight to determine its age?

Mr. LEMB KEY. No. sir.

But he finally is compellsd to admit that the measurement of the salt-cured skin is a reliable indication of its age.

\section{[Hearing No. 9, pp. 399, 400.]}

Mr. McGillcudDy. If you took a young skin and for the purpose of making it appear by weight older. you could deceive?

Mr. JEMB KEY. Ve certainly could deceive. We could fill it with any sort of sul)stance.

Mr. McGrlucundy. You say measurement would not be reliable because it might be stretched. Suppose you did not stretch it, suppose you take it honestly, then would it be, if honestly taken, would it be a test?

Mr. LEMB KEY. I tried to make that clear to tlie committee.

The CHAIRMAN. That is a direct question. Why do you not answer it?

Mr. LEMBKEY. I am attempting to. It is impossible; of course all our actions up there are honestly

Mr. MADDEN (interposing). Answer the question right straight. Do not try to explain it. 
Mr. LEMBKEY. I have attempted to state that in measuring a green skin it is impossible to find out its exact length when you lay it on the ground, because it may curl up, or roll, or stretch, and it can only be measured after it has become hardened by salt.

Mr. McGillicundy. Then it will not stretch?

Mr. LembKey. Certainly not.

Mr. McGillicudDy. That is the proper time to measure it, after it has become rigid and stiff?

Mr. Lembkey. Certainly.

Mr. MoGillicudoy. You can not then stretch or shrink it?

Mr. LEMBKEY. No, sir.

Mr. McGillicudoy. With an honest measurement of that kind of skin would it not determine the age?

Mr. LembKeY. I fancy, yes.

Mr. McGilucudor. Is there any loubt about it?

Mr. Lembkey. I do not think so. I say, fancy, because I never attempted to judge of age by the measurements.

Mir. McGilicudoy. In that way, if anyborly wanted to, they could not deceive, because you say they could not stretch it?

Mr. LEMBKEY. You could not stretch it after it had been salted four or five days, because the skin then is not very pliable.

Mr. McGillicuddy. Then it is your idea that measurement is reliable after a certain number of days?

Mr. LEM is EY. Yes, after it has been in salt, but when the skin is green it would not be a reliable test.

\section{EXHIBIT G.}

Yopies of oflicial entries in the jomrnal of the United States Treasury agent's office, St. Goorge Island, showing the impossibility and the futility of getting an accurate "count" of all the live pups on a fur-seal rookery.

Extracts in recounting live pup seals taken from the official journal of the agents of the Government in charge of St. George Island, Bering Sea, Alaska. 'These records show the impossibility of getting an accurate count of all the live fur-seal pups on any breeding rookery.

These entries under the respeetive dates, as follows, state facts, to wit:

\section{Office United States Treasury Agent in Charge, St. George Island, Alaska.}

August 1, 1901.-With George and Joe Merculief went to Little East to count last pups and to determine thereby how much resistance may be expected from bulls at this early stage.. The pups were podded and driven east, being carefully counted as they narrowed out. Others under rocks and in coves were pulled out by hand and counted separately. The number counted was 631. As the total number is 434 less than we counted last year, a recount of the rookery will be made to-morrow.

In the afternoon, with George Merculief, Mike Lestenkof, and Rev. Kashavarof, counted the pups on north rookery. The same methods were used, except that from the roughness of the rookery space much more trouble was experienced. Here, however, the bulls were holding their positions without giving ground, and greatly hampering our count. We succeeded in passing from one end of north rookery to the other; finding in that stretch 1,148 pups, but in the western end of the rookery we were in some places unable to get farther than the edge of the rookery, because of numbers of bulls holding from one to 
five small cows each. In these places the count had to be made from the most advantageous position. Our total of 3,741 pups for the whole of north rookery is 2,004 less than the count of last year. We clubbed at least 10 bulls, having several narrow escapes ourselves, the clubbed bulls in every instance reviving and returning to the attack. I do not accept the count as satisfactory, and will go over the ground again in a day or two.

August 2, 1901.-Counted pups this morning on Little East and East Reef. No trouble from bulls was experienced, and a very satisfactory count was made. I took with me to-day M. Merculief, and we counted together, he having counted with Maj. Clark last year. We used the same methods of counting as he did. Our figures were as follows: Little East, 847 pups; East Reef, 787 pups. The difference between my figures to-day and yesterday for Little East is considerable, but I believe the count to-day is more accurate. While I felt satisfied with yesterday's count, I believe that one person counting can not cover the ground as well as two. We had no interference on the East from bulls. We went then to east rockery proper and began a count, but after working for an hour I found that the four men with me were not enough to keep off the bulls and handle the pups at the same time. We, therefore, returned to the village at noon, and after dimner returned to east rookery with seven men. With them the bulls were put oft and kept off, and the pups handled in much more satisfactory manner. The total number we found to be East, 2,075 pups. Adding to this the number on East Reef, we have East 2,075 ; East Reef, 787, against 3,047 for last year. Dead pups. Little East, 6; East Reef, 3; East, 36.

August 5. 1901.-With Nikolai, George and Joseph Mereulief, I counted pups on Starre Arteel this morning. A total of 2,346 live pups were found there. Our counts were very satisfactory. Nikolai and I counted some pups in many instances, and on several occasions our counts were exactly the same. In other cases our differences were only two or three. Our greatest difference was 15 pups in a pod of over 200 , and in that instance I split the difference.

In the afternoon I counted with the same men the pups on north rookery. I detailed George to count dead pups, and the other two men counted live ones. As before, the bulls in many instances were tenacious and charged us instead of going the other way. One small cow having a new born pup charged us several times, and then picked up the pup in the mouth and carried it farther away from us. Three newly born pups were found, two with placental still adhering. Quite a number of small cows appeared to be still not served, and with these is always found a green, pugnacious bull. Our total was 4,503 live pups for north rookery and 1.25 dead pups. At the western end of the rookery we were unable to cover a space of 50 yards because of the presence of fighting bulls. For that space we counted 395 pups, all we could see from the edge of the rookery, and to that added 100 for those below, which were hidden by a drop at the water's edge. I believe that there were at least 200 niore jups there, but I do not feel willing to make the estimate too high. With this exception of 100 , the figures giren as the total represent pups actually counted.

August 7, 1901.- With Stepan Lekanof, 1. Philamonof, and N. Malaransky, George, Joseph, and Nick Merculicf, I counted pups on Zapadnie. We counted 4,113 live pups and 51 dearl ones. Two 
dead cows were found, one having died very lately, her skin bitten to pieces. Although the natives, who judge from the general aspect of the rookery, say there are more cows there this year than last, the count to-day is 1,229 less than the number given last year.

August 3, 1902, Sunday.-Counted pups, north rookery. Following are the results: Live pups, 4,852; dear pups, 43 ; dead cows, 3 .

Note by Mr. (hichester: We were able to carry on the counting from one end of the rookery to the other without molestation from the bulls. The count on this rookery, while I feel satisfied is as accurate as could be made, is far from satisfactory. The greater portion is so filled with large bowlders, beneath which the pups go, where they can not be reached or even seen, and it is quite probable a number were missed in the way.

August 5, 1902. - Counted pups on east rookery. Found on the east reef 905 live pups and 10 dead. Count satisfactory and as near correct as possible to get. Under cliffs we found 2,040 pups and 42 dead.

August 7, 1902, Thursday.-To Zapadnie for counting pups. Satisfactory count, as follows: Live pups, 3,822 ; dead, 77 ; dead cows, 3 . August 3, 1903, Monday.-Mr. Chichester and self, with 4 men, counted the pups on Zapadnie rookery, finding a total number of 3,462 . The count was under rather than above and very unsatisfactory.

Thursday, August 6, 1913.-Mr. Chichester and myself, assisted by George and Joseph Merculief, Nicolai Merculief, and Mike Shane and Gregory Swetzoff, counted the pups on north rookery. The aggregate proves to be 4,662 . There were a few dead pups, but the bodies of such were gencrally devoured or partly devoured by the foxes. We therefore did not attempt to get the census of the dead. Three cows were found dead. One had evidently caught her head between rocks.

Wednesday, August 1\%, 1904.-Three boats returned with nice cateh of sculpin, cod, and small halibut.

July 20, 1906.-At a favorable point on north rookery a cow in heat was teasing a bull, biting his neck and lifting up her hind parts, which the bull smelled. Shortly afterwards, he endeavored to copulate, but soon gare up the attempt, spreart out on the rock, and went to sleep. The cow renewed her blandishments from time to time, but the bull had evidently reached his limit.

Sunday, July 29, 1906.-In afternoon Maj. Clark and I went with a whole gang of natives and counted live pups on north and Starre Arteel rookery. The count on north is far from satisfactory, but it is as good as ean be made. Wherever it was possible the pups were hauled out from under the rocks, but in a number of instances it was impossible to do this, so the count is more or less guesswork. ${ }^{1}$ Result, north rookery live pups, 3,749 ; dead pups, 105 ; deact cows, 3 ; Starre Artecl, live pups, 1,958; dead, 48 .

Monday, July 22, 190\%. - Visited north rookery and found the cows very panicky and family discipline all gone.

I As an illustration of the curious inaccuracy of theseseal estimates made by the agents here, and honestly admitted as above (as well as on St. Paul), here is an entry made on Thursday, the 15th of July, 1909, which follows the work of the pelagic sealing fleet of the previous year, commencing August 1 , and not ending until the middle of October following; in spite of that slaughter and loss of life from the census and count made by these men. August 1,1908, we find this entry: "Counted north rookery as follows, 109 harems, 2,777 cows, 13 idle bulls; total bulls, 122 . Comparing the foregoing with last year shows a falling off of 100 cows and a gain of 7 bulls. But there are some bulls hauled with the bachelors, of which at least 5 should be counted as idle, making a gain of 10 bulls." 
ST. PAUL ISLAND JOURNAL.

July 11, 1909.—*** * At 4 p. m. the Rush came to anchorage on the west side, and without dropping their anchor immediately dropped a boat over the side, into which Mr. George A. Clark, of Stanford Tniversity, was placed and taken ashore. * * * Mr. Clark arrived under instructions from the department to investigate conditions surrounding the seal life at the present time. He was secretary to Dr. Jordan when the commission under that gentleman made its investigation of these islands in 1896 and 1897.

August 2, 1909....* * * In the afternoon Messrs. Judge and Clark and myself, with three native men, counted pups on Ketavie, finding on Ketavie 1,669 live pups and 60 dead, a total of 1,729, while on Amphitheater there were found 246 live and 4 dead pups, a total of 1,979 for both places. * * * On the space involved, namely Ketavie and Amphitheater, Mr. G. A. Clark counted on July 13th last 53 harems, as noted in this record of the date mentioned. On the 15 th I counted the harems there, finding $5 \mathrm{~S}$. Upon the basis of Mr. Clark's count the average harem on the space counted would be 37.3 , while on the basis of my count the average harem would be 34.1. I have adopted my count as the official figures. In view of the fact that Mr. Clark was more or less hurried in counting, due to the fact that he desired to catch the teams for Northeast Point which were waiting for him while he was counting. My count, however, was made two days later than the one made last year, and probably shows sereral harems more than if made on the 13 th as herctofore.

ST. GEORGE JOURNAL.

Friday, July 16, 1909.-Mr. George A. Clark landed from the Manning at about 10 a. m. He comes accredited to examine the rookeries. He is the secretary of President Jordan of Stanford University, California. In the afternoon went with Mr. Clark to east rookery. It was impossible to prevent all of the bachelor killables and many of the cows from being driven into the water. Mr. Clark did not count the cows. It is not possible to do so in the time given to individual harems.

Saturday, July 17, 1909.-Mr. Clark and Mr. Chichester went to Zapadnie to examine rookery. Mr. Chichester and Mr. George A. Clark counted bulls at Zapadnie, at Starre Arteel, and north rookeries. Mr. Clark and Mr. Chichester agreed in their counts.

Sunday, July 18, 1909.--'The Manning sailed for St. Paul at 7.30 a. 11 .

Tuesday, Auqust 3, 1909.-In the afternoon it cleared off, and I went to north rookery with Mr. Chichester and 5 native men and counted the pups with the following results: Living pups, 3,679; dead pups, 105; dead cows, 2. Thile the count on this rookery is always difficult and unsatisfactory, I think it was about as good as usual.

Friday, August 6, 1909.-Went in aftemoon to little east rookery and counted pups. The result shows 138 living and 1 dead pup. One dead cow partly eaten by the foxes. In $190 \AA$, when I examined 
this rookery, it showed 1,135 living pups. It has dwindled from year to year, until only the pitiful number above given remains.

Friday, August 4, 1911.- Took force of natives and with help of Dr. Mills counted the pups on north rookery. The count was very unsatisfactory, several bulls holding the young cows, causing the massing of the pups, and many of them to go into the water at the end of the rookery. The aggregate obtained was 4,146 pups, which approximately is a correct one. The dead pups were 155 .

Wednesday, June 12, 1912. - The supply steamer Homer came in at $6.30 \mathrm{a} . \mathrm{m}$. and brought the following named passengers: $* * *$ Mr. George A. Clark and son from Stanford University, who are to count the seals, Mr. J. C. Redpath, formerly company agent, for his health.

Monday, July 29, 1912.-Mr. Clark and his son went to Zapadnie to count pups, starting at 8.30 o'clock. Mr. Clark returned from Zapadnie in violent rainstorm, completely wetted through. $\mathrm{He}$ counted — pups at the Zapadnie rookery.

Tuesday, July 30, 1912.-Mr. Clark and his son went in afternoon to east rookery and made count of the pups. Mr. Clark reported as follows: East Cliffs 2,307, including dead. Found on East Reef, pups, 536; on Middle East, one harem, 26 pups. The total pups on Zapadnic and East is 4,115 .

Wednesday, July 31, 1912.-Mr. Clark and his son Paul went in morning with two native boys to assist and counted north rookery. North rookery shows 4,227 pups. In the afternoon Mr. Clark and his son Paul went to Starre Arteel and counted the dead and living pups, with the result that there were found on this rookery 3,607 living pups, a surprise to us all. This rookery was supposed to have a much smaller number.

\section{EXIIBBIT $H$.}

An exhibition of the remoral and subornation of the United States agents, on the Seal Islands of Mlaska, who were doing their sworn duty, by the lessees thereof: 1891-1909. Taken from the official records on the Seal lslands, and briefed from the sworn testimony to House Committee on Expenditures in the Department of Commerce, 1911-1912.

Proof of the removal and subornation of the United States agents on the Seal Islands by the lessees and their confederates. An exhibition of the summary treatment given to Treasury agents who did not serve the Seal Island lessees and do their bidding (said seal lessees being the North America Commercial Co., of San Francisco and New York).

In 1890 , July 20, the chief special agent in charge of the Seal Islands, Charles J. Goff, stopped the work of the lessees on July 20, because they were killing female seals and injuriously driving the young male seals in vain, to get their quota of 60,000 . For doing this, his sworn duty, in-

1891, April 5, Chief Special Agent Goff was removed, as follows, and a "docile" man put in his place: 
Mr. Elliott.-CONCERning the "OGDen MILLA LeTter" TO secretary charles FOSTER, APRIL 2, I891, AND ITS INCLOSURES

[See pp. 311, 312, Hearing No. 7.]

On Saturday, August 5, 1911, Mr. Bowers read into the record of this committee, for the purpose of discrediting me, a copy of a letter which I have searched in vain for during the last 16 years; it was the "Ogden Mills letter" of April 2, 1891; it asked Secretary Charles Foster, Treasury Department, to immediately overrule all the sworn official reports of his own special agents on the seal islands, and issue to the North American Commercial Co. (the lessees) a permit to kill 60,000 seals on the Pribilof Islands during the season just ahead-the summer of 1891 ("if they can be found").

These agents of the Treasury on the seal islands, four of them-Chief Special Agent Charles I. Goff and assistants, Joseph Murray, S. W. Nettleton, and A. W. Lavender, had all united August 1-14, 1890, in specific reports which urged that the Secretary of the Treasury permit no killing of seals in 1891 by the lessees, and for an indefinite future; those reports were supplemented by mine, dated November 19, 1890.

The tragic, sudden death of William Windom, January 29, 1891, brought a successor to the Treasury whom the lessees seemed to have completely in their control, for so complete was that control that the following astonishing record is made in the premises, started April 25, 1891, by issuing that killing order April 11 following and the full sequence of the "Ogden Iills" letter, above cited, to wit:

The sole warrant which this letter gave to Secretary Foster for asking him to set aside the verdict of those sworn officials above cited was "the inclosure of a series of five aftidavits" and a letter "signed by Capt. Healey, U. S. R. M.," all of whom declared in their "affidavits" and statements that after that clate on which the lessees' work was stopped, July 20, 1890, the seals "hauled out" in large numbers suldenly, and there were plenty of fine killable seals to be had, and would have been secured by the lessees if Elliott and Goff had not unjustly and perfidiously used their official authority to so order that stoppage.

This letter, though signed by Ogden Mills, was really written by George P. Tingle, who was the general manager of the lessees on the seal islands. Mr. Mills never could have written such a false and detailed letter of his own knowledge, and had he known the truth of what he was writing about, I firmly believe that he would have refused to sign it. I can not think otherwise, because it was such a letter.

In the first place, all those affidavits he has cited must liave been made after the 14th of Angust, 1890. They were made by the employees of the North American Commercial Co. under pressure from George $R$. Tingle, who also signed one of them; they were supplemented by a letter to Secretary Charles Foster, from Capt. Michael Healey, U.S. Revenue Marine, who toncherl at the islands in October, 1890, and who wrote to Foster about the "seals being as numerous then as they had ever appeared to him in all previous years." (Think of such a statement from such a man, who knew so little!)

Those "affidarits" were simply bogus-they were false ab initio. They were received by $\mathrm{Mr}$. Foster on $\mathrm{April} 3,1891$, in this Mills letter aforesaid, and then what happened?

On or about the 5th of April Mr. Charles 1. Goff was called into Secretary Charles Foster's office and told that he need not concern himself with the seal-island business any further; that "the rlepartment hach other business for him to transact at Montreal," Canada (i. e., looking after immigration cases). Goif was directed to proceed there forthwith (and he did). No complaint against him was utered by Foster-just called him in and sent him to Montreal in the "regular order of ofticial business," which governs all the sperial agents. Crolf was astonished; he was speechless, lut obeyed.

Then what happened? Un or abont April 9 a nan named W. 11 . Williams Was appointed "Chief special agent of the seal islands, vice Goff, transferred;" and on April 11 this man started for San Francisco from Washington with a secret permit from Secretary Charles Foster, dated April 11, to the North American Commercial Co.. giving them authority, as lessees, to kill 60,000 seals on the Pribiloi Islands luring the season just ahead, "if they can be found," etr. (IIearing No. 10, pp. 66.2, 663, Apr. 24, 1912, House Committee on Exprnditures in the Department of Commerce and Labor.)

Following this removal of $\mathrm{Mr}$. Goff', we have found by inspecting the official journal of the United States special agent's office, on St. Pauls Island, that on May 21, 1891, United States Special $\mathbf{\Lambda}$ gent $\Lambda$. W. Lavender, having sent word to the Treasury Department that the lessees were not living up to the terms of their contract, and heing 
guilty also of having joined in with Special Agent Goff August 1, 1890, in the same recommendation that the work of the lessees be suspended for the public good, gets summarily removed upon a trumped-up "charge," false and silly, the entries showing this are as follows, to wit:

On page 362 of the official record of the Treasury agent, St. Pauls Island, the following entry is made by Assistant Special Agent S. W. Nettleton, to wit:

Tuesday, June 23, 1S91.-The following official communications and telegrams were received by Treasury agent and Maj. H. Williams before sailing from and while in San Francisco:

William H. Williams, Special Agent,

$$
\text { Wastimgton, D. C., May 21, } 1891 .
$$

Care of Collector of Customs, San Francisco, Cal.

On the seal islands there are 2,371 salted sealskins, ${ }^{1} 1,255$ of which are claimed to be merchantable. Balance rejected skins. Deliver all to North American Commercial Co., subject to future settlement.

Attest: True copy. A. F. Gallagher.

Charles Foster, Secretary.

Washington, D. C., May 21, 1891.

This is the "report" from Lavender, which caused his removal:

$$
\text { United States Treasury Departaent, }
$$

William H. Williams, Special Agent, May $21,1893$.

\section{Care of Collector of Customs, San Francisco, Cal.}

Report from Lavender just received per steamer Bear that natives on St. George Island were insufficiently supplied during last winter with food and fuel and conseqently suffered hardship. Notify North American Commercial Co. that at least 70 tons of coal will be required for that island during coming winter.

True copy. Attest:

O. L. Spaulding, Assistant Secretary.

\section{A. F. Gallagher.}

This stirred Licbes, Tingle, Redpath, et al., up, and they lost no time in fixing up "charges," as follows. Their willing tool in the Treasury Department sends the following improper dispatch in the light of the department's orders of March 26, 1890, to wit:

\section{William H. Wrlliams, Special Agent,}

Wasuington, D. C., May 22, 1891.

Care of Collector of Customs, San Francisco, Cal.

It is charged that special Agent Lavender has neglected his duties, has abused and insulted Mr. Fowler, and also Dr. Herford, because the latter refused to give him money to buy skins. that he has been engaged in buying skins, of which he has a large collection. Investigate, and if he has skins in his possession, compel their delivery to company upon payment of a reasonable price thereior, to the natives.

$$
\text { (Signed) }
$$

O. L. Spaulding, Assistant Secretary.

True copy. Attest:
A. F. Gallagher.

What were these "charges" which declared that he had been "engaged in buying skins" of the natives, etc.? - witness the following-

1 These were a series of "small pup" or yearling skins, taken by the old lessees in 1859, which were not nccepted by the new lessees in 1890; but when they were shut out by the modus vivendi from getting more than 7,500 skins in 1891 they reached out for them.-H. W. E. 
The following order of the Treasury Department declares that Lavender had not been violating any rule of the department, as an officer, in buying skins from the natives, who have ever since $186 \mathrm{~S}$ been selling "pup" and yearling sealskins which they have been permitted to tan and dress for such barter, also fox skins. The following specific permit declares that Mr. Lavender in "buying skins" from the natives (he could buy from none other) was doing exactly what he had a right to do and what every officer of the Government, and visitor since 1868 to those islands, had done without objection from anyone or challenge from the lessees. (Copied from Official Journal, United States Treasury agent, St. Paul Island).

Treasury Department, Office of the Secretary, March 26, 1890.

Charles J. Goff, Esi.,

Chief Treasury Agent,

Seal Islands, Alaska.

SIR: * * * Until otherwise instructed you will grant the natives the privilege of selling the pup skins allowed them hy law, incliding such articles as they may trap and kill during the winter, provided that no contraband merchandise or spirittous liquors are received in exchange for them.

George C. TiCHenor, Assistant Seeretary.

A true copy. Attest:

Henry W. Ellliott.

In spite of this official order (which gave Lavender a clean bill of health), on Monday, July 23, 1893, Capt. A. W. Lavender was "relieved" at St. George Island, under "order" of "Chief Special Agent J. B. Crowley," dated July 20, 1893, who directs him to "surrender" his office to his (see p. 156, Treasury agent's journal, Monday, July 23, 1893) "successor" (one Ziebach, who is both "doeile" and subservient).

These men, United States Special Agents Goff and Lavender, not being "dlocile," were thus summarily deposed by Liebes (Tingle, Redpath) and Elkins, the contractors, who, greedy to get all in sight, find them in their way. The shame and pity of it, that such venal officials "high up" should have been in control of this valuable public property on the islands and in Washington.

Since this summary deposition of Goff and Lavender was made ostentatiously on the islands to the natives as well as to all the white residents thereon by Liebes' tools, Tingle and Redpath, then the other special agents, Murray and Nettleton, recanter, ate up their truthful words of 1890 , and mired themselves down in the shameful serrice of those public enemies, whom they were supposed and trusted to control and curb.

No man has, as a United States agent, been on these islands sinee 1890 up to the date of 1913, whom these greedy lessees and their tools in Washington did not send there or else direct when there and away from there.

When the agents of the House Committee on Fxpenditures in the Department of Commerce went up to these islands in .July, 1913, the first free and open examination was made of the condition of affairs thereon, which has been permitted since 1890 .

'This oppression, domination, and subornation of those United States 'Treasury agents by the lessees, which is so woll illustrated in these cited cases above of Chief Speeial $\Lambda$ gent Goft and $\Lambda$ ssistant Special Agent Lavender, becomes still nore pronounced and offensive in the following ease. 
When the sealing modus rivendi of 1891 was officially published in Washington, D. C,, June 15, 1891, its terms ordered a total suspension of the lessces' work on the islands for the year, save the killing of 7,500 seals for "natives' food," to wit:

AGREEMENT BETWEEN THE GOVERNMENT OF THE UNITED STATES AND THE GOVERNMENT OF HER BRITANNIC MAJESTY FOR A MODUS VIVENDI IN RELATION TO THE FUR SEAL FISHERIES IN BERING SEA.

For the purpose of avoiding irritating differences, and with a view to promote the friendly settlement of the question pending between the two Governments touching their respective rights in Bering Sea, and for the preservation of the seal species, the following agreement is made without prejudice to the rights or clains of either party:

(1) Iler Majesty's Government will prohibit, until May next, seal killing in that part of Bering Sea lying eastward of the line of demarcation described in Article No. 1 of the treaty of 1867 between the United States and Russia, and will promptly use its best efforts to insure the observance of this prohibition by British subjects and vessels.

(2) The United States Government will prohibit seal killing for the same period in the same part of Bering Sea and on the shores and islands thereof, the property of the United States (in excess of 7,500 to be taken on the islands for the subsistence and care of the natives), and will promptly use its best efiorts to insure the observance of this prohibition by United States citizens and vessels.

(3) Every vessel or person offending against this prohibition in the said waters of Bering Sea outside of the ordinary territorial limits of the United States may be seized and detained by the naval or other cluly commissioned officurs of either of the Lligh ('ontracting Parties, but they shall be handled over as soon as practicable to the authorities of the nation to which they respertively belong, who shall alone have jurisdiction to try the offense and impose the penalties for the same. The wituesses and proof necessary to establish the offense shall also be sent with them.

(4) In order to facilitate such proper inquiries as Her Najesty's Government may desire to make, with a view to the presentation of the case of that Government before arbitrators, and in expertation that an agreement for arbitration may be arrived at, it is agreed that suitable persons designated by Great Britain will be permitted at any time, upon application, to visit or to remain upon the seal islands during the present sealing season for that purpose.

Signed and sealed in duplicate at Washington this 15th day of June, 1891, on behalf of their respective Govemment4, by William F. Wharton, Acting Secretary of State of the Tnited States, and Sir Julian Pauncefote, G. ('. M. (i., K. C. B., H. B. M., envoy extraordinary and minister plenipotentiary.

William F. Wharton.

Julian Pauncefote.

On the 3d of May, 1s91, precerling this publication of the above morlus vivendi, the daily papers published an order from President Harrison leroking a secret permit for the lessees to kill seals on the islands during the season of 1891 , just ahead. That this action of the President was due to the uncovering of a shameful deal between the lessees and certain high officials the following sworn testimony declares bevond dispute. After Mr. Goff was "transferred" April 5,1891 , the following sworn testimony (which no one has presumed to deny) declares what took place at the instance of the lessees, in Washington:

[Hearing No. 10, pp. 665, 666, A pril 24, 1912, House Committee on Expenses in the Department of Commerce and Labor.]

Mr. Euliotr. Then what happened? On or about April 9 a man named W. H. Williams was appointed "Chief special agent of the seal islands, vice Goff, transferred;" and, on April 11, this man started for San Francisco from Washington with a secret permit from Secretary Charles Foster, dated April 11, to the North American Commercial Co.. giving them authority, as lessees, to kill 60,000 seals on the Pribilof Islands during the season just ahead, "if they can be found," etc. 
In order to fully understand what this secret permit thus given to those lessees really was-what an infamous transaction it really was-it is necessary for this committee to look back of April 2, 1891 (when the Mill's letter was dated), a little ways, to observe the following facts, to wit:

On November 19, 1890, and on January 6 following, Secretary William Windom and Henry W. Elliott went over to the residence of James G. Blaine, Secretary of State, in Lafayette Square. In his study there, on both occasions, Mr. Blaine discussed with Windom and Elliott the whole fur-seal question, and after a long session (on January 6) Mr. Blaine agreed to lay aside the claims of the lessees and adopt the Elliott modus vivendi, only stipulating that the closed season called for in it slould be five years instead of seven.

On January 6, 1891, Secretary Blaine declared to Henry W. Elliott, in the presence of Hon, Nelson Dingley, jr., chairman Ways and Means Committee, House of Representatives, that he was busy with the details of arrangement for this modus vivendi. He asked Elliott to be patient; to say nothing, and write nothing about it. Mr. Elliott promised him that it should be done, and he obeyed that request faithfully.

On April 7, 1891, Mr. James G. Blaine pledged himself to Sir Julian Pauncefote, the British Minister, during a conference at the State Department, to that modus vivendi plan of Elliott's, provided this offer was made officially, as first coming from Lord Salisbury. Sir Julian Pauncefote accepted the terms, and sent them by post that day to the British Premier in London. (See British Blue Book covering these dates, "U. S.," etc.).

On April 11, 1891, Secretary James G. Blaine authorized Charles Foster to give a secret permit to Stephen B. Elkins, for the lessees, authorizing the killing of 60,000 seals, "if they can be found" on the seal islands of Alaska! Think of it! Only four days earlier this high official had promised to suspend all killing on the islands if the British Government would do so in the water, and if the British Government would make this [his] offer of suspension to officially appear as if first coming from Lord Salisbury And Sir Julian had at once engaged to carry it out, and was then busy with it! (See British Blue Book, "U. S.," March-June, 1891, covering these letters, etc.).

Now, your committee can realize the pressure which the "Ogden Mills" letter of April 2, 1891, exerted on these particular high officials of our Government; what use those false "affidavits" were put to, you can understand.

How was that secret permit of April 11 found out and soon made public? By the rarest of accident. It was thus:

On or about April 8, Sir Julian Pauncefote was a guest at a certain private or social dinner given to him. His hostess sat beside him; during the progress of this entertainment. Sir Julian remarked to her that he believed that he had been instrumental at last in settling the vexed fur-seal question, and that Mr. Blaine and he had just agreed that no further slaughter on the islands or in the Bering Sea was to take place for at least six or seven years, or that until both Governments had thoroughly investigated the conditions, no killing was to be resumed, at least.

On the evening of April 11, following, this lady was at another social entertainment, and there overhead the attorney for the North American Commercial Co. congratulate an unknown person who stood beside him in the reception line over their success during the day in getting Charles Foster to give them a permit to kill seals; that "nobody in Washington knew anything about it," and "nobody was to know anything about it" either, etc.

In a moment it flashed on the mind of this lady that Sir Julian had been duped or those men were in error; second thought told her that the lessees' attorney (Gen. N. L. Jeffries) was one who knew his business, and it must be true. She had heard me tell how Mr. Blaine was pledged to a close season; so, on the following day slie called on me at the Smithsonian Institution and told me of what she had heard, all as above stated.

Astonished and mortified, I at once set to work to find out the truth. I knew that if this was a secret permit, that if I went up either to Mr. Blaine or to Secretary Foster, they would not admit it; it must be secret or it would be published, and I would, too, have been called in and notified of such an order, and the reasons why it was given over the denial of it by myself and all of the official reports of the department's seal agents. As Congress had adjourned March 4.189l, there was no way of getting a resolution of inquiry and the like introduced and passed. I therefore asked Congressman William McKinley, Jr.. who was still in the city, to call on Secretary Charles foster and put this inquiry sharply and squarely up to him.

Maj. McKinley did so. On Monday norning-I think on or about April 14, 1891 he called on Foster at the Treasury Department. Later, same day, he reported to me that Foster first shirked the answer; then admitted that he had given this secret 
order on April 11, and had given it after a full understanding with Mr. Blaine, who on that day had informed him that there was no hope of getting any modus vivendi from Creat Britain; that "the British were ugly," etc.

This report of Maj. McKinley aroused my suspicions as to the status in so far as Great Britain's part in the business was concerned. I knew all the time that the Canadians opposed my plan; but I had taken two letters over to Secretary Blaine in January and February, 1891, written to me from London, and by a gentleman who was very close to Lord Salisbury. These letters assured me that Salisbury was in favor of my modus vivendi. (I gave those letters to Mr. Blaine and he kept them.)

If anything was to be done to stop this infamous killing permit thus started under cover, it must be done at once and before the lessees' vessel was loarled in San Francisco and cleared for the islands. I knew that such a permit woukl be flashed instantly over to them there, and that this work of getting ready for the season's killing was surely under way.

On the 22d of April, 1891, I learned directly and positively that the British premier was not "ugly," wais not aware of the fact that he was secretly misrepresented here by our own high officialism in charge of this fur-seal question. Knowing this, then, I took the only step 1 could take as a good citizen to stop this infamous game as played between the lessees and Secretary Charles Foster, using Secretary Blaine as their shield. I wrote a brief, terse story of it, and signed my name; then addressed it to the New York Evening Post on the evening of this day, April 22. That letter was published in that paper Friclay, April 24, 1891. It stirred official Washington from top to bottom in the State and Treasury Departments. This exposure of that secretkilling order went all over the United States instantly in the press dispatches, and it canght the eye of President IIarrison, who at this time was on a railroad-touring circuit of the Pacific coast and somewhere in California. He vetoed this infamous killing order by wire, either from Los Angeles or San Francisco, on May 3, 1891 (or from some point in (alifornia). This was published in the New York Herald May 4, 1891.

Thus, Mr. Cliairman and gentlemen of the commitiee, you see clearly step by step the sin and shame and public loss wrought by this "Ogden Mills" letter, which has been read into your record by $\mathbf{M}$ r. lowers on the 5 th instant and done by him in the fatuous conceit that it discredited me; that those bogus "affidavits" and that false letter of Capt. Henley, which it inclosed to Secretary Charles Foster, branded me as a conspirator hired by the old lessees to break up the business of their successful competitors,

Now, Mr. Chairman and gentlemen of the committee, this is bad enough, but the worst of my recitation to you anent th is "Ogden Nlills" letter is to come, for I have this to tell you and to vonch for.

When the publication of President Harrison's veto of this seal-killing permit was published in the New York Herald, May 3, 1S91. Secretary Charles Foster had to give out to the press some warrant for his action in the premises. What do you think he did?

He prepared a quoted "interview" with himself and had it published in the New York Tribune (May 9, 1891, I think). In this statement he quotes parts of this Mills letter, but as though it was his.own version, and cites these "affidavits" as being his warrant for discrediting the official agents of the department. No mention of Ogden Mills is made by Foster in this Tribune article [or of the receipt of this letter aforesaid, by him].

Well, as President Harrison had acted so promptly and so honestly in the premises and was hurrying back to Washington to take up this wretched mess and do the right thing. I dropped the subject and returned to Cleveland and went to work in my orchards and my vineyard there. I was happy in the thought that I had foiled those venal officials and shut out those greedy butchers. I paid no further personal attention to this matter in Washington.

From 1891, April 22, to the end of November, 1894. I had no further hand in that inception and finish of that work of the Bering Sea tribunal, which framed those idle and abortive rules and regulations to protect and preserve the fur-seal herd of Alaska from destruction.

When. however, the failure, utter flat failure, of those regulations was self-confesserl by the close of the first season of their working, 1894, I came to Washington again and sought Gov. Dingley. Together, with Senator Frye, we agreed to make an effort to reopen and revise those worse than useless Bering Sea rules by legislation which would compel that revision. To that end I prepared a letter, which Gov. Dingley had read at the clerk's desk, December 11, 1894, in the House of Representatives, and he introduced, January following, a bill to favor the recommendations of my letter so read to the House. (H. R. 8633; Rept. 1849.) 
The bill was fully considered by the Ways and Means Committee. I appeared for it; the lessees approved it. It was reported out and passed by the House on February 22,1895 , but could not be reached in the Senate before adjournment sine die, March 4 , following.

Now, gentlemen, what happened? Ne come right back to this letter of Ogden Mills. A new administration took charge, March 4, 1895. I determined to get copies of those "aflidarits" which (harles Foster pulblished a mention of in the New lork Tribune, May (9?), as his authority for that suppression of my report of 1890 , and those of my official associates, Messrs. Goff, Murray. Nettleton, and Lavender.

I called on Secretary John G. Carlisle, of the Treasury. He evinced the liveliest interest in this question and asked Assistant Secretary ( "harles S. Hamlin to go with me to the chief supervising special agent's office and furnish me with copies of those affidavits, ('apt. Healey's letter, etc.

Did we find those aflidarits or the Healey letter? No. We tracer them out from the Ogden Mills letter receipt in April, 1891, to one division after another only to find that they had been received, had been noted, and had disappeared from the files when Charles Foster left the Secretary's office, March 4. I895.

Why were those "affirlavits" and that letter of Healey removed and taken from the official files when Charles Foster published notes of them as his official warrant for suppressing the sworn official reports of Charles I. Goif and his three assistants in charge of the seal islands for 1890, and my special report of 1890 to Mr. Windom? (ordered by act approved A pril 5,1890 ).

Why? Because their authors had perjured themselves, and if those "afficlarits" had been in the hands of John G. Carlisle the lessees would have been obliged in my opinion, by Mr. ('arlisle, to surrender their lease. That is why they were alsstracted by or with the full knowledge and consent of Charles Foster, Secretary of the Treasury, on or some time before Mlarch 4,1895 . Nobody else could have removed them or would have dared to do so, as I was told by the Treasury officials.

Those men whose names were signed to these bogus "affidavits" as inclosed in that "Ogden Mills" letter above cited are all dead save one. That survivor of this job is one James C. Redpath. He has been the general overseer and assistant general manager of the lessees ever since May 21, 1890, up to the hour that their lease expired, May 1, 1890.

In connection with the felonious abstraction of these "affidavits" from the Treasury files on or about March 4, 1895, as above stated, Mr. Hamlin and I searched in vain for the official joint statement signed by Chief Special Agent Charles I. Goff and myself, setting forth the specific reasons why we stopped the work of the lessees on July 20 , 1890 , on account of killing female seals, etc.

This joint statement was drawn up in Gen. A. B. Nettleton's office in the Treasury Department; he was then the Acting Secretary, since Mr. Windom's sudden death, January 29, 1891, left the Secretary's office vacant. Gen. Nettleton asked us to prepare and sign this statement, because he said that it might be necessary to have it in case the lessees sued the Government or attempted to do so. This affidavit, or joint statement rather, was signed on or about the middle of February, I think; I did not take a copy of it at the time, because it was entered and filed the day we signed it, and I had previously given Secretary Windom a report specifically made on this subject September 7, 1890 .

Pursuant to this understanding between President Harrison and his Secretary of the Treasury, (harles Foster, as early as May 4, 1891, that no killing by the lessees would be pernitted, except, 7,500 for natives food, the following order is found on the (thief Special Agent's Journal, St. Paul Island, under date of entry of "July 11 th, $1891 "$ :

On page 355 , under date of "Wednesday, June 10, 1891," Special Agent Josepl E. Murray makes the following entry:

While I was away from the village the Revenue Cutter Rush arrived and the following officers and other persons arrived and landed: W. H. Williams, Treasury agent, S. R. Nettleton, assistant agent, Milton Barnes, a special employee, J. Stanley Brown, special agent, Mrs. Nettleton and daughter.

True copy. Attest:

A. F. Gallegher. 
Also this is entered, as follows, on the same day as above, to wit:

[Telegram.]

Maj. W. H. Williams, Special Agent,

Washington, D. C., May 27, 1891. Care of Revenue Cutter Rush.

The Rush will receive orders to sail to-day. You and the other agents will take passage on her. On the Corwon will follow in a few days. By her will be forwarded to you full instructions. The memorandum copy of proposed instruction which you now have will be your guide until Corwin arrives. Maximum number is not to be determined and other modifications are probable. If 7,500 seal are taken before Corwin arrives you will stop killing and await instructions. See that the other agents take passage with you.

Charles Foster, Secretary.

True copy. Attest:

A. F. Gallegher.

And, under date of June 13, 1891 (p. 357), the following is entered: Office of Special Agent, Treasury Departuent, St. Paul Island, June 13, 1891.

A. W. LAVENDER, Assistant Agent, St. George Island.

SIR: You are informed that the Secretary of the Treasury for the present has limited the killing of fur seals for skins on the seal islands to seven thousand five hundred $(7,500)$ for the year 1891 . You will permit the killing of one thousand five hundred $(1,500)$ seals for skins on the island of St. George. Care should be taken that no more than the above amount are killed without further instructions.

William H. WiLliams,

A true copy. Attest: Treasury Agent in charge of Seal Islands.

A. F. Gallagiter.

Under date of June 13, 1891 (continued on p. 358) the following is entered:

Office of Special Agent, Treasury Department,

George R. Tingle, Esq., St. Paul Island, June 13, 1891.

General Agent North American Commercial Co.

Sir: You are informed that by direction of the Secretary of the Treasury the number of fur saals to be killed for skins on St. Paul and St. George Islands for the year 1891 is limited to seven thousind five hundred $(7,500)$. The above instructions may be modified later in the season; if so, you will be duly notified.

Respectfully, yours,

William H. WiLLiams,

A true copy. Attest:

A. F. Gallagher.

Treasury Agent in charge of the Seal Islands.

And this also, clearly and specifically stopping the killing at 6,000 seals on St. Paul, is entered on page 357, to wit:

Office of Special Agent, Treasury Department, St. Paul Island, June 13, 1891.

George R. Tingle, Esq.

General Agent North American Commereial Co.

SIR: In pursuance of department instructions tle killing of seals for skins, until further notice, will be limited to 6,000 on the island of St. Paul and 1,500 on the island of St. George.

Respectiully,

William H. WILLiams,

A true copy:

Treasury Agent in eharge of Seal Islands.

A. F. Gallagher. 
Here we have the most explicit and timely orders of the Secretary of the Treasury that not to exceed 7,500 seals are to be taken on the islands during the season of 1891 (that they are expressly taken under the modus vivendi is carefully concealed by the Secretary, and that they are to be taken only as food for the natives is also carefully omitted-but the limit of 7,500 for the year is positively stated).

Did these Treasury agents, Williams and I. Stanley Brown enforce that order? No! Witness the following exposure of their disobedience and malfeasance in the premises: (and for which service $I$. Stanley Brown was made general manager of the lessees business on these islands by D. O. Mills and Senator S. B. Elkins, after he had ordered the entire eontrol, July 8,1892 , of his office turned over to the lessees' agents. See Exhibit B.)

On page 361, Official Journal of St. Paul Island, under date of Saturday, June 20, 1891, is the following entry:

The company made a drive from Tolstoi, killing 116, filling the quota of 7,500.

Here is the official and final statement that on June 20,1891, just one week after the chief special agent, Williams, has notified the lessees that the killing must stop at 6,000 seals, when reached on St. Paul Island, that that limit was reached.

Did the lessees stop? No. Witness the following proof of that complete control and illegal work prosecuted by them:

Thursaday, June 25, 1891 (p. 365 Official Jourmal).-Made a drive from Zoltoi for natives' foot and killed 209. All accepted; prime.

Monday, June 29, 1891 (p. 367).--Made a drive for native food from the reef, $400 ; 395$ prime; 5 cut; all accepted; 1,620 seals were driven: 75 per cent of the number driven were turned back into the sea. * * * The Rush left about 11 a. m. for Unalaska, taking as a passenger Treasury Agent Lavender, bound for St. George Island.

Tuesday, June 30, 1891._* * * Treasury Agent Murray and Mr. Leibes left this morning for Northeast Point.

Wednesday, July $\delta, 1891$ (p. 382).-Marle a drive from Zoltoi and killed 100 for natives' food. All accepted.

Thursday, July 9, 1891 (p. 382).-The revenue cutter Corwin came to anchor at the west side at $2 \mathrm{p} . \mathrm{m}$. from Unalaska.

Monday, July 13, 1891 (p. 385).-Made a drive from Zoltoi and killed 121 seals for natives' food. All accepted. Revenue cutter Corwin returned from St. George Island and anchored on the west side, bringing as a passenger for this island, MIaj. Williams, chief Treasury agent.

Wednesday, July 15, 1891.-Made a drive from Lukannon and killed 122 seals for natives' food. All accepted.

Tuesday, July 21, 1891.-Drove seals from Hiddle Hill and killed 179 , of which 178 were accepted as prime. One rejected; small. Was given to the natives and one was given to H. M. S. Pheasant, to be sent as a specimen to Provincial Museum, Vietoria, B. C.

Monday, July 27, 1891 (p. 390).-Drove seals from Middle Hill and killed for food 248 . All the skins accepted as prime.

Tuesday, July 28, 1891 (p. 390).- Steamer Danube, from Victoria, B. C., came to anchor this morning and landed the British commissioners, Sir George Vaden-Powell and Dr. George Mercer Dawson, also their two secretaries. At $6 \mathrm{p}$. $\mathrm{m}$. the United States steamer Albatross, Capt. Tanner, from San Francisco, with the American 
commissioners on board, Prof. Mendenhall, Dr. Merriam, Messrs. Brown and Lavender, came from St. George.

Wednesday, July 29, 1891._ * * * In the evening the British and American commissioners held a joint meeting at the Government house. The meeting was a private one.

CThis "private" meeting was not private in so far as the British commissioners were concerned. They demanded the reason why the killing was going on for food seals then, when there was no need for it. Why more than 7,500 seals had been killed up to date of their arrival, and was still in progress?

Thereupon Williams and Stanley Brown told them that they had not received their instructions to that effect until the arrival of the Comvin on the 9th of July last, and that the killing had not exceeded that instruction. The official journal quoted above convicts these tools of the lessees of telling an untruth to the British commissioners, who at the moment could not deny their falsehoods.

That is why this "meeting" is called a "private" one in the Williams-Brown journal, and as above entered therein by Joseph Murray, assistant agent. H. W. E.

Monday, August 3, 1891 (p. 393).-Drove seals from Reef rookery and killed for food 118, one of which was cut. All were accepted.

Sunday, August 9, 1891 (p. 397). -The Albatross sailed for St. George with the American commissioners, Prof. Mendenhall and Dr. Merriam, aboard, also Mr. J. Stanley Brown.

Monday, August 10, 1891 (p. 400).-Drove seals from Reef, Lukannon, Tolstoi, and Middle Hill and killed for food 408, of which number 405 were accepted. 'Two given to the natives.

Tuesday, August 11, 1891.— * * $*$ The sealskins were counted by Maj. Williams and they counted to 10,782 for which receipts were made out in triplicate. $* * *$ After the division was made Maj. Williams went on board the Farrallon, and the following employees of the North American Commercial Co. also went aboard to go to San Francisco: George R. Tiugle, B. Liebes, A. Hansen, Dr. Hereford, and G. Lee. Mr. Redpath went on board to go to Unalaska for a few days. The plan is to sail about 2 o'clock tomorrow morning. Before leaving Maj. Williams instructed Assistant Agent Murray to writc instructions for the assistant agents who are to remain on the island of St. Paul and St. George during the winter.

Thursday, August 13, A. D. 1891 (p. 402).- In pursuance of an assignment of MIaj. W. H. Williams, representing the United States Treasury Department, I this day cntered upon the duties of assistant agent in charge on this island.

\section{Milton Barnes,} Assistant Agent in Charge.

At page 406, under date of Friday, August 28, 1901, the following entry appears:

Office of Special Agent,

Treasury Departaent,

St. Paul Island, August 21, 1891.

Milton Barnes,

Sir: Before leaving for Washington, D. C., Maj. W. H. Williams instructed me to write instructions for the assistant agents who will have charge of the fur seal islands during his absence.

* * No seals are to be killed for food or for any other purpose prior to November 1 , nor even then if it be known they are stagey. * * * The whole number of 
seals to be killed on St. George Island for natives' food from August 10, 1891, to May 1, 1892 , is limited to 800 , and it is of the utmost importance that that number shall not be exceeded under any circumstances. So much depends upon the faithful fulfillment of our national pledges we must not do anything to prejudice them. * * *

Joseph MURRay,

First Assistant Agent.

Here is the written record officially made of the fact that the lessees actually continued to kill seals (on St. Paul-4,782 of them-large, choice seals) after they had been ordered not to do so by the Treasury Department.

And still more; if it had not been for that protest which the British commissioners made July 29, as above stated, in that "private" meeting, those lawless lessees and their official confederates would have continued to kill "food" seals during the rest of the year.

This exhibit declares that nothing stood between the lessees and their uninterrupted seal killing during the modus vivendi but that quick action of the British commissioners; the prohibition of the President, the specific orders of the Treasury Department, and their repeated reiteration by Chief Special Agent Williams, that nothing to exceed 7,500 "food" seal skins should be taken, was to them, a mere use of words to eoneeal their illegal work, not to stop it; il fulgur brutum, in short.

They took 10,782 skins on St. Paul, when ordered not to exceed 6,000 during the entire season.

They took 3,218 seal skins on St. George when ordered not to exceed 1,500 during the entire season.

And they did all that up to, and by August 11, 1891, with the official orders prohibiting that killing posted June 13, 1891, on the islands.

Mr. J. Stanley-Brown who shares this malfeasance with Special Agent Williams in 1891, came up again, June 9, 1892, as the United States chief speeial agent, and on Friday, July 8 , following, turned the entire control of the killing over to the lessees; and, for that service, he was made the "superintendent" of the lessees' business on the islands in June, 1894. (See Exhibit B.)

W. H. Williams, the agent who was put (suddenly) April 5, 1891, in Goff's place by Charles Foster, and who was so seleeted because Foster had complete control uver him, went up to St. Paul Island and landed there June 10, 1891. He was aceompanied by Joseph Stanley-Brown, who also went as Charles Foster's "own man" to get the facts.

It will be noted in the foregoing statement, that when Williams, after cooperating with Brown in this killing of some 14,000 seals during the season of 1891 , in violation of the international law which fixed it at 7,500 for that year--it will be noted that he leaves the islands on August 11,1891, and returns to Washington.

Does he ever return to these islands? No. Mr. Joseph StanleyBrown takes his place; and, on Thursday, June 9, 1892, arrives on St. Paul Island as the chief special agent in charge.

What had Williams done? Why was he quietly put over and transferred to London as Goff before him had been transferred to Montreal?

He was transferred because he spoke plainly, after his unpleasant experience on the islands during the summer of 1891, as a tool of the lessees. He told his friends at home, and in Washington, that this 
work on the islands must stop, and the lessees put out; he saw the greedy hand that prevented any settlement with Great Britain, and was ashamed of his part in the business of illegally killing those seals under the whip of the lessees; and, among other plain truths, he said:

In my opinion the only way to save the Pribilof herd is by an entire cessation of sealing for a considerable period. I have heard diverse views on this subject, and about closed seasons of 1 to 10 years as being the only way to restore the herd to its best form. I believe in 10 years.

Whatever period is adopted it should involve the entire cessation of seal killing on the islands. Of course, I am speaking unofficially, as I have no part in the present deliberation of the commission. (Fur Trade Review: Oct. 1, 1898, p. 446, New York.)

And as for J. Stanley-Brown, this is the same "scientist" and "keen business man" who was introduced to the House Committee on Expenditures in the Department of Commerce and Labor, April 20, 1912, in the following "modest" terms, by the United States Bureau of Fisheries, to wit:

Dr. Evermann. One of the interesting phases of this question that has attracted my attention is the attitude which some persons have assumed toward the large numbers of able and distinguished naturalists who have visited the seal islands and who are without question the men most familiar with the fur-seal herd and the many problems connected with its management and effective conservation.

Within the last 25 years nearly a score of the most distinguished naturalists not only of this country, but of Great Britain, Canada, and Japan have visited our seal islands for the specific purpose of studying the habits of the fur seals and the problems connected with the proper management of the herd. Among these gentlemen I may mention the following:

Dr. Everuann (reading):

"Dr. Barton Warren Evermann, in charge of the Alaska fisheries service, who, as special fur-seal commissioner in 1892, spent six months on our seal islands in the North Pacific and on the Russian seal islands, studying the fur-seal rookeries, hauling grounds, and migrations.

"Mr. Joseph Stanley-Brown, of New York, spent the seasons of 1891, 1892, 1894, $1895,1896,1897$, and 1899 on the seal islands, where, as naturalist and keen business man, he made very thorough study and investigations not only of the habits of the seals but very valuable study of the economic questions in volved." (Hearing No. 10, pp. 518-519; Inouse Committee on Expenditures in the Department of Commerce and Labor.)

The "value" of Joseph Stanley-Brown's "studies" to the lessees can be at once grasped by the most casual observer, but to the public interests which he was sworn to guard, and paid to do so, that value, no man living or dead, can find the least evidence of.

"That the greedy lessees however, found him "valuable" enough, goes without question, for we find this entry made on p. 222 of the St. Paul .Tournal, to wit:

WEDNESDAY, June 6, 1894.

Steamer Lakme of the North American Commercial Co. arrived, having on board J. B. Crowley and wife, as chief agent, and Mr. Judge and wife, also Mr. Brown, superintendent of North American Commercial Co., Mr. Chichester, and Mr. Armstrong.

The services of Joseph Stanlev-Brown are invoked by the Bureau of Fisheries to renew the seal lease and defeat pending legislation which prevents that renewal, and the following sworn proof of this collusion is submitted herewith:

Mr. Eliotr. And I want Mr. Bowers to pay some attention to this because this is important, at least some good lawyers have told me that it is very important to him-

"Being an official letter covering a 'memorandum' addressed to George M. Bowers, commissioner, urging him to take steps to prevent the passage of the Dixon fur-seal resolutions introduced in the United States Senate by Senator Joseph M. Dixon. (S. Res. 90, 91, 92.) 
"December 7, 1909, This letter from the 'bureau,' dated December 16, 1909, and, signed by Barton W. Evermann, urges Bowers to send agents to New York, there to "educate" the Camp Fire Club and induce them to agree to the 'bureau's idea of renewing the lease," as follows:

\section{"[ExнiвIT No.6.]}

"DEPARTIENT OF COMMERCE AND LABOR,

"Bureau of Fisiteries,

"Washington, December 16, 1909.

"The Commissioner:

"The Washington Star of December 10 last announced that the Campfire Club, of New York, had inaugurated a campaigu to save the fur-seal herd through legislation designed to prevent the re-leasing of the sealing right, the cessation of all killing on the islands for 10 years except for natives' food, and to secure the opening of negotiations with Great Britain to revise the regulations of the Paris tribunal. As the result of this movement, on December 7 three resolutions were introduced by Senator Dixon, of Montana, one of which embodies the provisions before mentioned, the other two calling for the publication of fur-seal correspondence and reports since 1904 .

"As the object of this movement is at variance with the program of this bureau and of the recommendations of the advisory fur-seal board, notably in the plan to prevent killing and the renewal of the seal island lease, the advisability is suggested of having Messrs. Townsend. Lucas, and Stanley-Brown use their influence with such members of the Campfire Club as they may be acquainted with with the object of correctly informing the club as to the exact present status of the seal question and of securing its cooperation to effect the adoption of the measures advocated by this bureau. ${ }^{1}$

"The attached letter is prepared, having in view the object stated.

\section{"Barton IV. Everman.}

"Exhibit No. 7. Being the official letter of 'George M. Bowers, commissioner, to Secretary Commerce and Labor, dated February 8, 1910, inclosing copies of three letters, all urging renewal of the seal lease and giving the reasons of the writers for such renewal, to wit, H. H. Taylor, president N. A. C. Co. (lessees), dated January 27, 1910; C. H. Townsend, for 'fur-seal advisory board,' dated January 31, 1910; Alfred Fraser, London agent for the N. A. C. Co. (lessees), January 28, 1910, as follows"; (not printed):

LETTERS OF CHIEF SPECLAL IGENT CHAS. J.GOFE, WHO IVAS IREAOVED

FROM THE SEAL ISLANDS OF ALASKA BY TIE LESSEES APRIL 5, 1891, BECAUSE HE WOULD NOT PERMIT THEM TO VIOLATE TIE LAW AND INJURE THE PUBLIC PRESERVES TIEREON, WRITTES TO SHOW US FULL KNOWLEDGE OF THE RASCALITY WHCII SECURED HIS REMOVAL, MAY 9, 1891, AND AUGUST 16, 1891, AND EXPOSJNG TIIE SAME.

(Mr. Goff was the brother of United States Senator Nathan Goff, of West Virginia. He died several years ago.-H. W. E.)

\section{Montreal, May 9, 1891.}

My Dear Mr. Elliotr: Your favol just received, and I am glad you are still in the land of the living and ready and willing to expose the Bering Sea steal. You say there will be a commission go to the islands this summer to investigate. I am afraid 'Tingle will have

1 COMMITEE ON EXPENDITURES IN THE DEPARTMENT OF COMMERCE AND LABOR, HOUSF OF REPRESENTATIYES, Friday, Jume 9, 1911 .

The committee met at 10 o'elock a. m., Hon. John H. Rothermel (chairman) presiding.

TESTIMONY OF MR. GEORGE M. BOWERS, COMMISSIONER OF FISIIERIES.

Mr. Bowers. No new lease was made, but the killing was done under governmental supervision.

Mr. Tow ssevd. You will he questioned about that later. After the first suggestion of this bill you now of no efforts that were made to delay the passage of that legislation"

know of no efforts that were made to delay the passage of that legistation

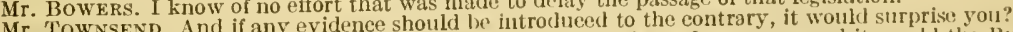

Mr. IOWNSEND. And if any evidence it would, yes; and as far as I am coneerned it would the Burau

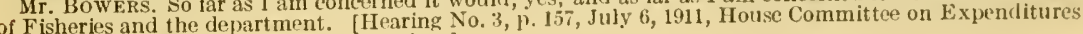
in the Departinent of Commerce and Labor.] 
slaughtered the herd before anyone gets ready to start. It will be his plan to kill old and young, to make a good showing. He will kill yearlings, for the price of seal skins will insure him a return of his money on them. He will use every effort to make as large a daily killing as possible to flaunt in our faces. The new agents will see this, and, not posted by Murray and Lavender, will be led astray. This is surely the plan mapped out by the gang. Anything to down our reports, if they hare to pass through fire and brimstone, and, my dear sir, that man Nettleton is a tool in their hands; he is the most gay deceiver of all. I know some few secrets I will tell you when I see you next. I hardly think an investigation will help our party, for this is one of the foulest steals I ever knew, and it will give the Democrats a war whoop in the coming campaign and one that will bear fruit.

If the seals are saved through your efforts you will have gained your point, and why not then rest upon your well-earned laurels and sleep upon your well-loaded arms for a future combat with Tingle, etc.

Let me again warn you that there is a deep and well concocted scheme to have reports come down this fall in direct opposition to ours, and no one knows what all of this planning and skirmishing may bring forth. A full Ohio delegation, one that could be trusted. Do you think there is any ambiguity about that sentence? The captains or commanders of the cutters are against us. Tingle will raise the cry that he who opposes will be deposed. You know how he will coach his entire surrounding; then again, those we left behind may fall into line under this great pressure, and we are left standing alone. I know all of this won't make seals; they eare not for that; they are fighting for vindication, and when they have secured that they will come forward and suggest a close season, claiming. the increase of poaching this year has made it a necessity. The public will be none the wiser. They will take charge of the islands, and the steal will go. Remember this, and also remember that what I write you is " entre nous."

When do you expect Murray and Lavender down? They will be down early, I should think. Please keep me posted on their arrival. With regards, your friend,

Charles J. Goff.

Montreal, August 16, 1891.

Mr De.AR Mr. Elliott: Tingle is surely trying, with the effort of his life, to place us before the public in a ridiculous light; and I am fearful that he will sueceed, but, my dear sir, it will only be for a short while. Nurray will come down with his mendacious statement, and Tingle will have one from him and all his employees, and it will present to the public a very plausible contradiction of my report, and your thesis.

You remember I told you Tingle would never cease working, that he would resort to any means foul or fair to accomplish his end; see the double duplicity of the man, sccuring, as he says he did, Murray's removal while here, and then returning and courting his favor and using him as a henchman to do his infamous work. Poor Murray; was ever man so treated? It kept me constantly guarding him last 
year to prevent Tingle from fooling him. And I was always fearful that he had not the determination to withstand the pressure brought upon him by the company crowd. I don't claim to be a scientist or capable of writing an extensive dissertation upon seal life, but I am surprised that Murray would assert that he wrote ny report. He is surely losing his wits, as this acknowledgment will give him away, if he assumes to hold the position which Lutz alleges he does, and has no force whatever upon the subject matter at issue. Now, Professor, if this crowd presses us too hard, I want you to call for an investigation and I will stand by you until the last. I was opposed to it all along, but Williams, Brown, and Barnes can't misrepresent facts and expect us to accept their statements, placing us in a false light before the American people, without an effort to vindicate our actions. We are right, were right last summer, are right now, and may we live long enough to see right prevail. You can count on me standing by you in this matter, until I am called over Jordan; and, if I meet Tingle on the other side, I'll quarrel with him there over it. Your lasting friend,

\section{Cilarles J. Goff.}

\section{SEPTEMBER 18, 1891.}

Prof. H. W. Elliott: Your letter of the 5th came duly to hand and I am so sorry I am unable to give more than the most meager details respeeting the killing on St. Paul and St. George up to the 15th. I have just learned that it was prearranged that Murray was to be decapitated officially and that at Washington Tingle represented him as being crazy and consecquently entirely unfit to hold any responsible position under the Gorernment at the Seal Islands. It seems Tingle knew all the time that he was patting and pumping Murray that the latter's tongue had already been long enough to hang himself with. However, I imagine that Tingle represented to Murray that the latter had no friends: that they had all "gone back" on him, just as he did to me, although, at the time, I knew he was lying. Tingle also possibly represented himself as the only person able to save Murray in ease he was in danger. He could cause the removal of whomsoever he pleased ; and he could, if he wanted to, cause any one's position to be secure. Murray eagerly swallowed such bait as this together witl all the belittling statements and slanders that Tingle eould invent respecting yourself and Mr. Goff. It appears as though Tingle did really intend, at least for a while, to do something towards rewarding Murray. At any rate . Ir. 'Tingle prepared and wrote out a statement to the effect that " We, the undersigned," having messed with the Hon. Jos. Murray for the past 1.5 months, had ever found him to be a most worthy upright and honorable gentleman, and a wise, capable, intelligent, and efficient officer, always kind to the natives and a jealous and watchtul guardian of the Government's interests, etc.

The paper was handed to me by 'Tingle with the information that he would like me to read it orer, sign, and return it to him. It was already signed by J. C. Redpath, N. A. C. Co.'s agent on St. Paul Island, and Edward T. Baldwin, bookkeeper. I read it over and after considering a moment I returned it to Tingle with the remark that I really did not think I could put my name conscientiously to that. 
Tingle was somewhat nettled, apparently, and thereafter nothing was left undone to make my position on the island as uncomfortable as possible. Every move I made was watched, reported, and commented on. One would have thought I had committed some great crime, or that I had the smallpox, the way I was shunned. Even the natives did not dare to be seen speaking to me. I felt that everything I did was subject to be grossly misconstrued. This was the condition of affairs in regard to myself shortly after Tingle's arrival. But now Tingle's animosity was intensified. From the first I did not dare to venture near the rookeries nor near the seals on the slaughtering grounds, because I could not feel certain that I would not thereby subject myself to mean and insulting remarks by Tingle. In this way I failed to know just exactly how things were going on. Nevertheless, I ean say this much: As soon as Tingle arrived (on the 7th, I think) he gave orders to kill as many seals as possible before the 15th, and to take even is small skins as $4 \frac{1}{2}$ or $4 \frac{1}{4}$ pounds. I heard him give the order a number of times. I thought at the time that he wanted to hurry and get as many skins as possible before new orders arrived, and I supposed that he expected these new orders to arrive on or about the 15 th. I can easily see now that he very likely was being aided with information by the politicians, otherwise, it oceurred to me, how could he have known that the proelamation was going to be signed on the 15th. Surely it was no accident. At any rate, before the 15 th seals were very scarce, and there can be no doubt that Fowler, Redpath, and Tingle never worked harder in their lives to get the seals, but the seals weren't there to get. Drives of $80,100,150$, and 200 were made, aceording to report brought to me by the natives. I had an idea Tingle wanted to get 7,500 skins before the 15th in order to say: "Well, we got 7,500 so easy; we got them all before the 15th." But, at any rate, counting all they had before, they couldn't make up to 7,500 until the 20th of June. Williams claims they took 6,250 skins after the 15 th, and the Farallon brought down something like 14,000 skins. I do not remember the exact number the Farallon brought down, but it was considerably over 13,000. The killing was stopped on the 28th or 29 th of July. These latter drives were much larger than the earlier ones, and the so-called food skins were the very choicest to be had and the largest. A rery small number was not obtained, despite considerable anxiety and, effort, on St. George Island, until later, much later, I believe, than the 20th of June.

Murray and Lavender are ret on St. Paul and St. George. They are expected very shortly on the Corwin. Murray tried very hard on the islands to blarney Lavender, but apparently without entire success. If Murray stuck to it that the seals were not there, is it possible that he would have been removed just for that? Apparently Goff was not wanted. Tingle was almost demoralized when he learned that there was a likelihood of your coming up with the British commissioners. You never saw a more nervous, fussy, and frightened man than he was at that time. Lavender is not wanted. It is rumored his head is to come off. And now I learn that Murray is to be removed, I suppose the proviso is - if he persists in advocating what is displeasing to Mr. Elkins. Nettleton, I supposed, they were afraid to attack on aceount of his brother. 
Williams is not in favor of the company appointing the schoolteachers and physicians. Neither was Mr. Goff. In case the Government should appoint physicians next year I would like to have the job. I should give up any position I had in order to accept any such appointment. Wouldn't I like to show 'Tingle I could get there whether he wanted me to or not However, after a while, when Congress meets, if you have the opportunity, I would be grateful for any effort you might make to obtain for me an appointment as physiciain at one of the Indian agencies. I have applied at all the steamship offices, but there seems but little likelihood of my obtaining anything to do. Mrs. Lutz sends cordial and kindest regards to Mrs. Elliott. My little Mary is quite a large girl now, and is growing nicer all the time.
Very truly, your friend,
C. A. Lutz.

Comuttee on Expendtures in the

Departalent of Commerce and Labor.

House of Representatives,

Wedncsday, April 24, 1912.

The committee met at 10 o'clock a. m., Hon. John H. Rothermel (chairman) presiding.

JOHN HAY IS INFORMED BY HON. JOHN A. KASSON OF THE SUBORNATION OF THE DEPARTMENT OF STATE BY THE LESSEES OF TIIE SEAL ISLANDS. 1890-1891.

[Statement of Henry W. Elliott.]

The Chalruan. All right then. I suppose it is the sense of the committee that the statement shall go in?

Mr. Patton. I have no objection.

The Chatruan. Then it is so ordered.

Washington, May 12, 1903.

Dear Col. Hay: I do not know why the inclosed is sent to me, except for my sympathy with Elliott in the matter of the Alaskan seals. Nor do I know what to do with it except to place it at your disposition to decide if there is wisclom in lis suggestion.

Very faithfully. yours,

KAssox.

(Given to me by Mr. Hay, in Department of State, June 20, 1903, 11.40 a. m.H. W. E.)

LAKEWOOD, OHIO, Маy 10, 1903.

My DeAr Mr. KAsson: In packing away a lot of papers to-day I came upon those minutes of the interview which took place between Sir Julian and myself in April 1891. You suggested that I put them into writing after I had recited them to you in your residence, December 10, 1901. I inclose a copy of them.

Reading them over, the thought occurs to me that the desperate condition of affairs on the seal islands to-day warrants Sir Michael in doing exactly what Sir Julian did in 1891. He can override the Canadians and agree upon a modus vivendi for 1904 , just as Sir Julian did for 1891.

Sir Julian took this action solely on the strength of his belief in the truth of my represention and report of 1890 . Sir Michael can have not only all of this ground, but the important additional data which I have placed in Mr. Hay's hands.

I had to go as a stranger, personally. to Sir Julian in 1891. on account of Mr. Blaine's "infirmity" of purpose. Mr. Hay can go to Sir Michael with vastly greater effect and tact than I went to Sir Julian. Ile can take these authentic records, illustrations. facts, and figures which I have given him recently and lay then with great empliasis before the British ambassador.

Something must be done this summer and before Congress meets. Otherwise, it naught comes from the State Department, the pending seal bill, now lying in the Senate Foreign Relations Committee, will be passer in short order, as at measure absolutely necessary to save the fur-seal species of 1 laska from complete extinction. 
It would be a great feather in Mr. Hay's cap, and also for that of Sir Michael, if such a modus for 1904 was agreed upon as was that of 1891 .

I have never said a word to Mr. Hay about this particular matter and the securing in 1891 of that modus vivendi which I urged in my report of 1890 . I do not know whether I ought to. If you think it proper and will serve as a useful side light, I venture to ask that you see Mr. Hay and talk it over with him, for, really, the more I think of it the more I am inclined to believe that Sir Michael can easily do again what his distinguished predecessor did in the premises, and for which action he was highly rewarded by his Government, in spite of the bitter opposition of the Canadians.

With every regard for you, I am, faithfully, your friend,

Hon. John A. Kasson, Washington, D. C.

Henry W. Elliott.

THE SWORN PROOF ENCLOSED TO JOHN HAY BY MR. KASSON IIAY 12, 1903, OF THE SIBORNATION OF THE DEPARTMENT OF STATE BY TIE SEAL CONTRACTORS, 1890 1891.

\section{Washington, D. C., December 10, 1901,}

During a call made upon Mr. John A. Kasson this morning and for the purpose of understanding fully what the High Joint Commission did about the fur-seal question before it was strangled by the Boundary dispute February 22, 1899, Mr. Kassou said 10 me that I ought to reduce to writing that account which I had given him of the adoption of my modus vivendi of 1891-1893; this account to be sealed and not broken during the life of the British ambassador, the other party, James G. Blaine, being dearl.

I therefore make the following statement, which will constitute a complete sequel to my diary notes of what took place between Mr. Blaine and myself prior to my interview with Sir Julian.

Wednesday, April 22, 1891: After due reflection and in spite of the fact that I had never met the l3ritish minister, I resolved this morning to call upon him and put the question directly to him whether or no he had refused to entertain any proposition for a modus vivendi in Bering Sea for the protection of the fur seals, as he was charged with doing by ('harles Foster on the 13th instant (see preceding memoranda).

I took the Connecticut Avenue street car on F, corner Tenth NW., and entered the Pritish Legation door at half past 100 clock in the morning; the servant took my card, left me standing in the hall, returned in a few minutes saying that Sir Julian was dressing and would see me when he came down. I was ushered into the office, which opens directly from the hall, opposite the drawing-room. I had penciled on my card the words "concerning the fur seals of $\mathrm{Alaska,"} \mathrm{so} \mathrm{that} \mathrm{he} \mathrm{might} \mathrm{know} \mathrm{what}$ I wis after.

I was not alone more than 10 or 15 minutes belore Sir Julian came into the room, and he greeted me with the greatest courtesy, saying that he had heard a great deal about ine and that he hat asked Secretary Blaine to introduce me several times.

I replied, saying that I too had often asked Irr. Blaine to present me, but that he had not done so.

I have called on you, Sir Julian, this morning on my own responsibility. I do not come from Mr. Blaine. I have come to make an inquiry which may be improper; if it is, pardon me and give no answer, but. I want to inform you that an order to kili (i0.000 fur seals was given to the lessees of the seal islands on the 11th instant; that this order to kill was based upon the refusal of your fovermment to unite with mine in a modus vivendi whereby all killing on land and in the sea is to be suspended during the coming season in Bering Sea. If this refusal of your Government to act with mine is authentic, then I want to say to you from my full knowledge and understanding of the question that killing 60,000 young male seals on the Pribilof Islands this summer means the absolute extermination of that life up there, and the shame of this rloing is upon your Government.'

Sir Julian's manner instantly changed as I spoke; his expression became one of intense surprise; he answered in language substantially as follows, walking up and down the end of the room where we were standing, alternately facing and partly turning from me:

"It is not true; my Government has been trying to get Mr. Blaine to agree upon some such plan ever since the opening of March, and it was not until the 7 th day of this month that he agreed to it, and $\mathrm{I}$ am expecting to hear by return post of the acceptance by my Government of the modus vivendi. I posted the offer of Mr. Blaine on the same day and immediately after he made it to me. Really, my dear sir, you surprise me. I do not believe that Mr. Blaine knows what he does want. I have been having quite a time trying to find out." 
We then talked a few minutes about the condition of the seals, the attitude of the Canadians, and of our lessees. He said that it was a case in which the testimony was exceedingly conflicting, and that under the circumstances the only humane and wise thing to do was to stop the killing for a season at least and look in to the matter during the meantime. He said that as far as he was concerned his sympathy was for the seals and he would give them the benefit of every doubt.

I then took my departure, having been with him about half an hour.

HENRY IF. ELLIOTT.

THE RECAPITULATION OF THIS SUBORNATION OF THE DEPARTUENT OF STATE BY THE SEAL LESSEES 1590-1S91.

[Note for Hov. John H. Rothermel.]

When John Hay asked me on June 20, 1903, to take this letter of mine, as written to Hon. John A. Kasson, of May 10, 1903, with its recitation of the amazing revelation of Mr. Blaine's malfeasance as made by Sir Julian Pauncefote, and inclosed to Mr. Hay by Mr. Kasson, for this purpose, as stated by the latter, Mr. Hay said: "This is a matter" which I can not discuss with you. I know it is true and that makes any use of it at this time and in this department impossible. It is best returned to you, and my desire is that nothing be said in the premises at the present time and while this business is pending between Canada and ourselves.

Just think of this terrible revelation made by Sir Julian of Mr. Blaine's duplicity, and worse, as Secretary of State, thus made to me, April 22, 1891-think of it in the light of the following facts, to wit:

March 15, 1891. Sir Julian Pauncefote urges Mr. Blaine to agree upon a modus vivendi for the coming season in Bering Sea, whereby no killing of fur seals shall be done on the Seal Islands of Alaska by American citizens and no killing at sea shall be permitted for British subjects; in the meantime both high contracting parties shall carefully study the question and then agree upon a plan of proper resumption of seal killing, etc.

Mr. Blaine demurred and suggested a 25 -mile zone of pelagic prolnibition around the Seal Islands instead; to this Sir Julian objected, saying that it was impracticable and would not be easily enforced, etc.

April 7, 1891. Sir Julian again urges Mr. Blaine to unite with his Government in a total suspension of all killing of fur seals on the Pribilof Islands and in the sea of Bering, during the coming season of 1891. Mr. Blaine agrees to do so if the British Government will notify him of its desire and willingness to do so.

Sir Julian Pauncefote then mails to Lord Salisbury this proposal of Mr. Blaine to stop all killing on the Pribilof Islands during the season of 1891, if the British Government will prohibit its subjects from all killing of fur seals at sea (in Bering Sea), during this period aforesaid. This letter sent to New York and mailed by "special post" on this day and date, April 7, 1891, to London.

April 11. 1891, Secretary Blaine, without informing Sir Julian, violates this agreement of April 7, 1891, as above cited; he gives to the lessees of the Seal Islands (D. O. Mills, Isaac and Herman Liebes, Lloyd Tevis, and S. B. Elkins), a secret permit to kill 60,000 seals on these islands, "if they can be found," during the season of 1891.

April 13, 1891. Charles Foster, Secretary of the Treasury, admits when personally interrogated by Hon. Wm. McKinley and Henry $\mathbb{W}$. Elliott, that he has given this order of permission to kill 60,000 seals, "because Blaine authorizes it, and has told me that Salisbury is ugly and will not stop his people from killing."

April 22, 1891. Sir Julian Pauncefote denies that his Government "is ugly," and asserts that it is willing to stop the seal slaughter.

April 24, 1891. Henry W. Elliott in a half column letter to the New York Evening Post of to-day's issue, under caption of "Some Seal History," tells this story of Mr. Blaine's duplicity and venality, as above cited; it is telegraphed all over the country, briefly, and on-

May 3,1891 . President Harrison vetoes or orders the cancellation of this secret and infamous permit; he then orders steps to be taken in the State Department. which result, June 14, 1891, in the modus vivendi being officially published, as originally suggested by Henry W. Elliott, November 19, 1890, and Sir Julian, on April 7, 1891, as stated above.

Washington, D. C., May 2, 1912.

Henty W. Elllott.

(Hearing No. 10, pp.670-672, A pr. 24, 1912.) 


\title{
INVESTIGATION OF FUR-SEAL INDUSTRY OF ALASKA.
}

\author{
('OMMTTEE ON EXPENDITURES IN THE \\ DEPARTAENT OF COMMERCE AND LABOR, \\ IIOUSE OF REPRESENTATIVES, \\ Saturday, May 4, 1912.
}

The committer mat at 10 o'dock at. m., Ifon. John H. Rothermel (elaiminan) presiding.

Present: Mressrs. Ýoung, MeGillicuddy, and MeGuile.

\section{STATEMENT OF LEONHARD STEJNEGER.}

I AONHARD STE.JEger, having been duly sworn, was examined, and erstified as lollows:

Mr. Elliott. Since rou have suggested that remarkable order of work on the Russian Islands, rou ale quoted by one of your associates recently, before nuother cominitee, as saving that onc bull seal was sufficient to serve 250 or 500 females. Are you really properly cututed there?

Dr. STEJNeger. I an cortaimly misquoted.

Dr. Everuaxi. There is no streh quotation.

Mr. Ellotote. I hare it here published.

Dr. Everuax. I ask Mr. Elliott to produce it. Now is the time to produce it.

Mr. EusorT. IIere it is. LExhibiting paper to the eommitec.| Now, right here, in the Scattle Sunday Times, issue of October 11, 190S, I state to Mr. Frank H. Hitehcock, who has quoted from Dr. - Jordan's letter to him, dated Jamuary 12, 1904 (Swarthmore Collene. Pennsylvania), [reading] :

[Seattle Times, October \&, 1908.]

NATURAL SCIENCE MIUSED TO SERTE BUTCHERS OF FUR-SEAL HERD OF ALASKA HENIRY W. ELLIOTT, ()F LAKEWOOD, OHIO, ASSERTS THAT DR, DAVID STARR JORDAN AND JOHX W. FOSTER WERE AGEXTS OF ANIMAL DESTROYERS AND SUBMTS WHAT HE DECLARES TO BE PROOF.

\section{Entor the THES:}

A friend in Seattle sends me a clipping from the Seattle Times, issue of the 20 th instant, in which I am properly quoted as saving that "Jordan and John W. Foster were agents of the land butchers of our fur-seal herd, "etc. IIe asks me if I am not mistaken, or if this is not a misprint, ardding that Dr. Jordan is "well known as the hearl of Stanford Cniversity," and as such "could hardly be in such relation to those men, "ete.

I wish to answer him in your columns, and to tell him that I am correctly published in The Times as above cited, and since this question is raised as to my atuthority for such a serious charge against Dr. D. S. Jordan, I submit to your readers the following proof of the entire sense and justice of $m y$ charge:

On the 8th of January, 1901, I addressed a detailed letter to the Secretary of ('om-merce and Labor. In this leiter I set forth at length the reason why I desired the department to put an immediate stop to the work of the lessees of the seal islands of Alaska in killing seals as they did on the islands. I declared that if the department did not make this check upon that work, then the male breeding life of the Pribilof rookeries would be extinct by the close of the season of 1907 .

Mr. F. H. Hitcheock at that date was the chief clerk of this department. Then he told me that he had been very much impressed by my letter; that he was inclined to agree with me. "But," said he, "I want to be entirely" frank with you; all of our agents and the associated naturalists do not agree with you; they say that there can be no danger to the life of this herd from the effects of land killing such as you assert exists. Are you willing that I send a copy of your letter to Dr. Jordan, who has been our chief adviser and guide in this matter?" 
I made instant assent, and Mr. Hitcheock mailed a copy of my letter, abowe cited, to Dr. D. S. Jordan, (are of Swarthmore College, Pa., where he was at this time. ()n Tuesday, January 12, 1904, Mr. Hitcheock receiver from Dr. Jordan a long letter in reply to mine thus sent to him, and on Friday, January 15, 1904, Mr. Hitrhonck reat Dr. Jordan's letter to me, in his office at the department. Asking his stenographer to take down my words, I made the following reply to Dr. Jordan's letter. (I retained this copy of those notes.)

"I am much indebterl, Mr. Hitchcock, to you for this courtesy on your part, in reading that letter from Dr. Jordan, which you have just received, to me-a versonal letter? Well, then, of course, its text is confidential between us. But what I have to say now concerning it I give to you for any use, publir or private, that you may desire.

"I assume that the Secretary and yourself can have but one object in view touching the past and present status of our fur-seal herd; that that object is to beenme at one.e possessed of the whole truth in the premises, and nothing else, either of a personal or of an impersonal relation, to this business. At the outset, and before I take up a brief review of this long, rambling, personal letter which you have just read, I must say that Dr. Jordan's assertion that I have 'had no scientific training' is a gratuitou. falsehood. He knows it, too; he knows now and he knew 20 years ago that came to the Smithsonian Institution in the winter of 1861-62; that I at once entered the family of Joseph Henry, its direetor, as his private and confidential secretary; he knows that I was engaged then, officially, as the artist of that establishment ; he knows that my whole time, when not busv with Prof. Henry, was occupied with naturalhistory work and investigation under the immerliate direction of Spencer F. Baird and a corps of his able associates in the Smithsonian Building. At that time I was trained br these men so well that when it became possible for the Smithsonian to select a man, in $A$ pril, 1872, fit for the work of makrng a complete and original biological survey of the then entirely unknown seal herds on the Pribilof Islands, I was then selected from 18 active, well-trained candidates for this task-selected by Joseph Hemry and Spencer F. Bairl for this especial mission, becanse they deemed me the best fitted.

\section{SCIENTISTS LAUD WORK.}

"The result of my work so pleased these real scientists, when I returned and finished it, that they never failed, by word of mouth or in writing, to land it; it has also received world-wide approbation, and is to-day the same authoritative, unshaken volume in the naturalists' library that it was when first issued, 20 years ago. Jorlan knows all this; he presumes, however, upon your ignorance of it; he, therefore, humiliates himself at the very opening of this letter to you. He has had no such training under such able men as I have had; few men ever have. This is all I intend to say about myself. It is imperative that I should say as much, since it has been fairly forced upon me by the impudent, patronizing, and arrogant language of reference to myself in this letter, reflecting upon my ability and my motives."

1. In his letter you observe that he does not submit a single statement of fact, or a single figure to deny the tabulated statements of fact and figures which are embodied in $1 n$ letter of January 8 (1904) to the department; he advances nothing but a series of unfounded and unsupported "opinions" and "beliefs." He does so because he is utterly unable to do anything else in the premises.

II. He starts in by making the mistake of attempting to break the force of my presentation of the condition of affairs on the seal islands by descending to insinuation and implications, in effect, that I am "unfriendly" to the lessees of the islands-that I am "hostile" to them and hence I am trying to injure them. What are the facts in this regard?

In 1890 , after the repeated sight of the lessees' men killing cow seals "in milk," in three successive drives on St. Paul Island (prior to July 20), I ordered this illegal and improper work of the lessees to stop; I did so, because they were violating the law under my eves, and I had no alternative, if an honest and competent public officer. of course this action aroused the "hostility" of the lessees. Was it wrong on my part? No.

$$
\text { SECRET TREASURY PERMIT. }
$$

Again, on April 2:2. 1891, I intereepted and prevented the granting of a secret Treasury permit, dated "A Aril 11," 1891 , to kill "60.000 seals" if they, the lessees, could find them on the Privilof lslands during the season of 1891; this also aroused more of that "hostility" of the lessecs. But this permit was an infamous ancl scandalous one, and President Harrison on that account was compelled to veto it May 3, 1891. 
Again, I forced my modus vivendi of 1891 through in spite of the secret upposition of Necretary Blaine and of the open opposition of the lessees and the Canadians June 14, 1891. I was able to do this by the prompt steps taken by Sir Julian Pauncefinte, and the pressure arumsed jublic opinion here at home.

Therefore, with this explanation, I plead guilty to Dr. Jurdan's rharge of being "hostile to the lessees"'; hut is that charge not one of infinite credit to inyself? Who, salse this dull man Jordan, fails to see this point?--that man Jorlan, who has constantly pleaded the cause of these seal butchers and has not voiced the sense of a raal naturalist since 1896 in behalf of the fur-seal life of Alaska-that man Jordan, wh'. in this letter to you just read, calls me a "lobbyist," because I have gone and now where I should and must gu to plead the necessity of checking up those butcher-ou these islands-to the me and only source of power which was not under the brief control of those land lutchers in 1895,1896 , and 1897.

111. Dr. Jordan sees no danger ahead, in his "opinion," from any excessive land killing of young male seals by the lessees; he wonld let this work proceed as usual, hut lie woild have it under the direction of a "trained naturalist.

Just think of it. That wretched fiasco which he has made of his work on the islanis as a "trained naturalist" in $1896-97$, he wants to renew on these islands in 1904 . He Wants (1) supplement the "trampled pups," the uncinaria or "sand-worm scourge," 1 la" "successiul abolition of pelagic sealing by branding all the female seals," and lif. "perfect agreement" with his British associates; he wants to supplement this ricliculous record of $1896-97$ with a crowning finish in 1904; he wants to finish the life itwelf with the aid of another "trained naturalist" and another joint "conmission.

let me tell you, my dear sir, that Dr. Jordan shomld not be permitted to indulge

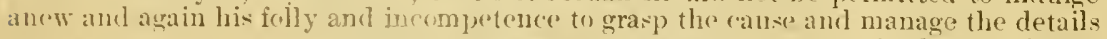
of this business. Ihe stands betore you a self-confessed inconpetent in the promiseshe has had his day in court-he should not be further indulged if orfinary care and prudence is exercised by Congress and the Executive.

IV. He says that this fur-seal business should be "put in charge of the Bureau of Fisleries," and "a trained naturalist over it" in turn. I deny it; you want a man of good common sense, of fair education, and sterling integrity; such a man you want as your agent on the seal islands; one who is known to be careful and thoughtful in the ordinary walks of life and suc'essful in its affairs. Such a man is so much better than a mau like Jurdan that I can not well express in modest terms the length, depth, and breatth of his superiority.

$\checkmark$. Do not waste another hour with "trained waturalists" in this arlministration of detail in fur-seal hnsiness, which is now in the secretary's office. Keep it here, just as it is to-dlay; kerp) it here where good business sense can quickly reach and control it.

\section{WORK THOROUGHLY DONE.}

The work of the "trained naturalist" has been done; it has been so thoronghly done by me in $1872-1874$, that no man up to this hour has been able to add one authentic biological line to the published whole of my "Mfonograph of the Seal Islands of $A$ laska," issued in 1881, by the Tenth Census, and the United States Fish Commission. Not a single line of biological truth has Jordan and his job lot of naturalists been able to add to my original story of $\mathrm{my}$ investigation into the life and habits of Alaskan fur seal; then, too, other men than these naturalists of the Jordan party, have been hard at it trying to discredit me ever since 1891 , and all of them have failed. Witness. C. $\mathbf{H}$. Merriam, J. A. Allen, Geurge M. Dawson, and F. W. True Not one of them has been able to point to a flaw in my elaborated work of 1881 , or add a single truthful line to it of the least sense or value.

But some of them have been unwise and foolish enough to deny my statements of 1890 as to the injurioms and improper work of the lessees in land killing; that a large part of the loss to that fur-seal herd was due entirely to overdriving and excessive fand killing of the young male seals by the lessees, this being done by them ever since 1872 .

Now, most all of these men know better but are silent in the shadow of Jordan; even Stejneger, with his fairy tale of 2 bulls being enough to serve 500 cows (which Jordan so gravely quotes here to you with all of the pompous gravity and true coarseness of ignorance)--even he ean not find a trace to-day of either those "2 bulls" or "500 cows," which he so specifically describes on Copper Island in 1896. Good reason--they are extinct. That ghost dance has ended forever over there. But Jordan does not even know it at this late hour.

VI. In conclusion I want to ask you frankly if you really believe that any man of ordinary intelligence and prudence would have been puerile enough tis have recommended the branding of female fur seals as a means of surely putting an end to the business of the pelagic hunter? 
And, again, do you believe that such a man would have asked Congress to pass such an absurd act as is the Davis Act of 1897? Why, it has driven all of our pelagic hunters-vessels, capital, and men-over to Victoria instantly. There they are to-day, under the British flag, meaner and uylier, if anyining, than their Canadian brethren.

Then, too, this absurd act contains a section which orders the confiscation and destruction of every sealskin and sealskin garment that comes into our borders unless it has a certificate of capture of the Pribilof Islands. Think a moment of the folly of this stupid measure, which, instead of depreciating the value of the pelagic skins, has actually caused them to advance 150 per cent in price within three years after the said act became a law-December 17, 1897. This is the brilliant work of Dr. Jordan, the "trained naturalist," and it fitly finishes his most mischievous work on the seal islands; it is an act which has done nothing but annoy and disgust nur own people, and is a farce ab initis as a means of securing the least abatement of the pelagic hunter's work or of destroying in the least the value of his skins.

VII. Jordan tells you in this letter that "the pelagic hunter is bankrupt"-that this man "is going out of business," "Bankrupt," indeed. Thy, he took 27,000 skins from the Alaskan herd this year just past, upon which he will clear a net profit of not less than $\$ 300,000$; he took 22,817 skins last year, or, rather, 1902, and cleaned up some $\$ 230,000$ over all expenses, plus capital, interest included.

Does this look like his "going out of business," and his "hankruptcy"? It may look so to an ignoramus but not to you or to me.

\section{INDUSTRY PASSES INTO TRUST.}

Jordan also does not seem to know that this pelagic industry has passed into a "trust" at Victoria, ever siuce 1898; that a single executive officer now directs that business far better than it has ever been before-far more deadly for the seals, and keeps its counsel so well that Jordan has not been equal to seeing or understanding the real situation. "Going out of business," and "We are bankrupt," and many other similar bogus proclamations have been annually given to the public by the pelagic hunting chief ever since 1890. They fool no one by any means, unless he is a dull one. But it is true, however, that there are a great many dull ones in official life, as well as in business circles, and this pelagic hunter knows it -he has lauded Jordan, hard and heavy.

In conclusion, I desire to say that it is a fortunate thing for the cause of truth and the preservation of this seal life, now at stake, that four of the ablest and best Senators of the United States made a personal visit to the seal islands of Alaska last summer. They have seen the sin and shame of the condition of affairs thereon, and they have avowed their desire to make an end of it

I trust that your stenographer who has followed me will not leave out one word of this recitation which I now end. Publish it or not, just as you see fit; it is the truth. 1 have an immense amount of detailed proof in my hands.

Therefore, Mr. Editor, your readers can, in the light of the foregoing analysis of Dr. Jordan's letter of January 12, 1904, clearly see him rushing in to prevent the Department of Commerce and Labor from putting any check upon the work of the land butchers such as I demanded. He not only scoffed at my argument, but slandered it, and myself, to serve these butchers. That followed my answer, as above stated?

Mr. H. F. Hitchcock, the chief clerk of the department, said to me that he was greatly embarrassed by this difference of opinion between Dr. Jordan and myself; that not only Jordan, but Dr. C. Hart Merriam, Dr. Leonhard Stejneger, Mr. C. H. Townsend, and all of the special agents in the islands (Lembkev, Clark, Chichester, and Judd), disagreed with me - that the "weight of evidence was against me"; but, he added, "I an much inclined to believe that you are right."

\section{MATTER CARRIED TO CONGRESS,}

After looking over the ground carefully and feeling quite sure that the department was bound up to Jordan in this improper and ruinous understanding for the good of the public interests at stake, 1 carried this matter of checking that improper work of the lessees from Mr. Hitchcock's office up to 'ongress, and had the question raised in the Ways and Neans Committee Narch 9 and 10, 1904. Mr. Hitchcock, representing the Secretary of Commerce and Labor, then appeared and said to the committee that, although the "weight of scientific evidence was against me," yet he would "order that check desired." It was done May 1, 1904, and this order is known as the "Hitchcock rule."

Under date of October 2, 1905, the seal island agents reported to the department that these "Hitchcock rules" have been absolutely necessary to prevent the complete extinction of the male breeding life on the seal islaud rookeries-that I was right, and 
they were all wrong when they disputed me, with Jordan as their mentor, in 1900 to 1904, inclusive.

(See S. Ex. Doc., No. 98, 59 th Cong., lIst es., pp. 70-82, inclusive.)

One word in conclusion, as to the status of Dr. Jordan's associate, ex-Secretary of On On February 3 , had called on him the un finshed business of the Hay-Elliott treaty plan for settlement of this fur-seal question. etc. In other words, that this old diplomatic jobber had been hired to do all he could to prevent action on this Hay-Elliott treaty plan aforesaid.

Well, action up to date has been prevented. How much longer depends upon the President, from this hour on.

1437 Grace Avenue, Lakewood, Ohio.

HenRy W. ElLiotT.

Dr. Stejneger. Mr. Chairman, shall I explain the whole thing? Mr. ElliotT. Yes.

Dr. STEJNegrer. It is a somewhat lengthy story, but I think personally that it is Mr. Elliott that has tried to make fun of one of my observations

Mr. Elisiotr. No, indeed; I have not.

Mia Jordan misquote Steineder? observe what the latter published - viz:-

"Astounding - ns it appears, there can be but "latter dom be chat the single old bull had "served she great majointy of the 526 females "on oh is rookery (Goludinnoye) and monera "was in fish condition to keep the younger "bull ah a respectful distance r as lase "in tho seastar as lily 20."

"Om Deal Investigation: Tart 1V: 1898: p.168.) 
Jovalan made no mistake about Stejnejer,

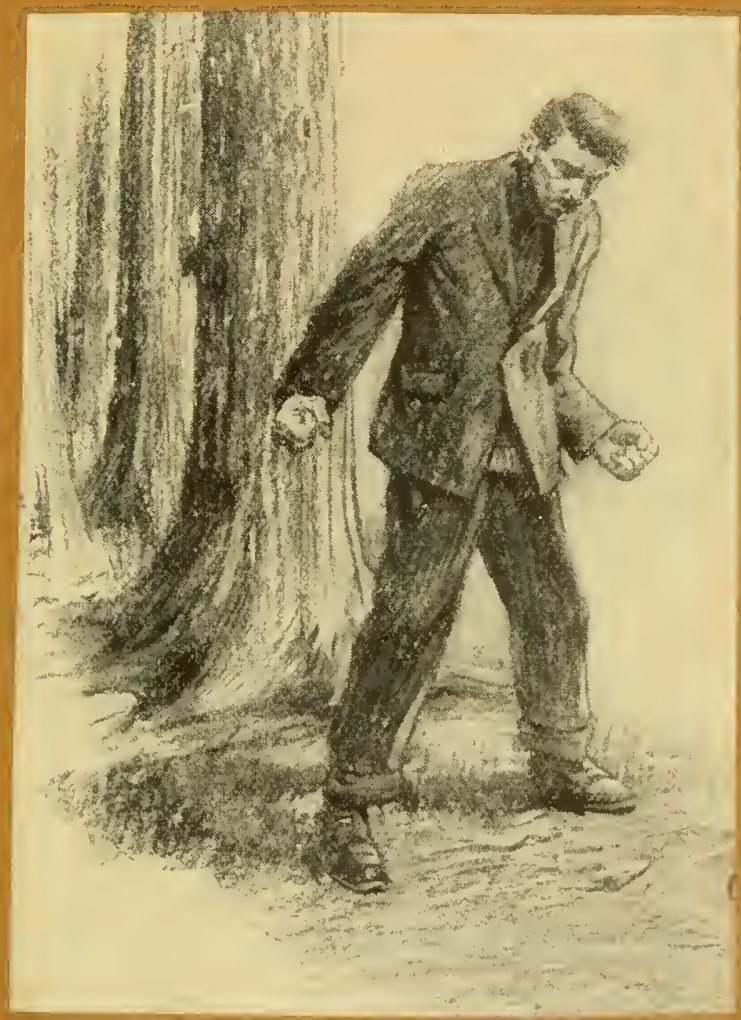

"I feel like Stejueóer dia - I
-want to kick myself -ugh!" 


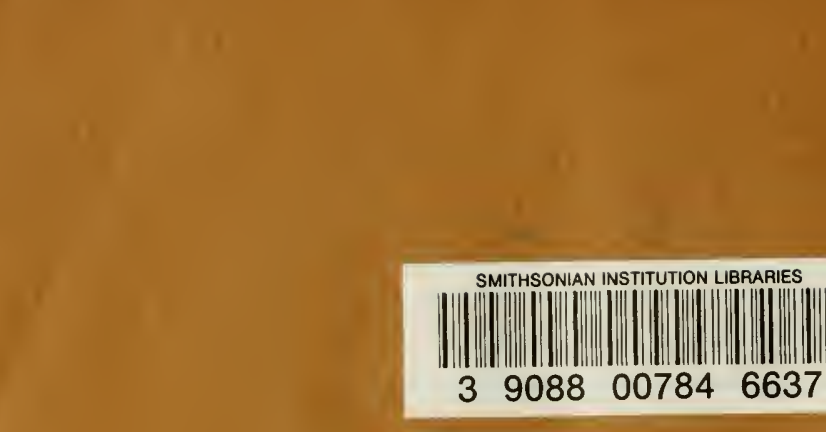

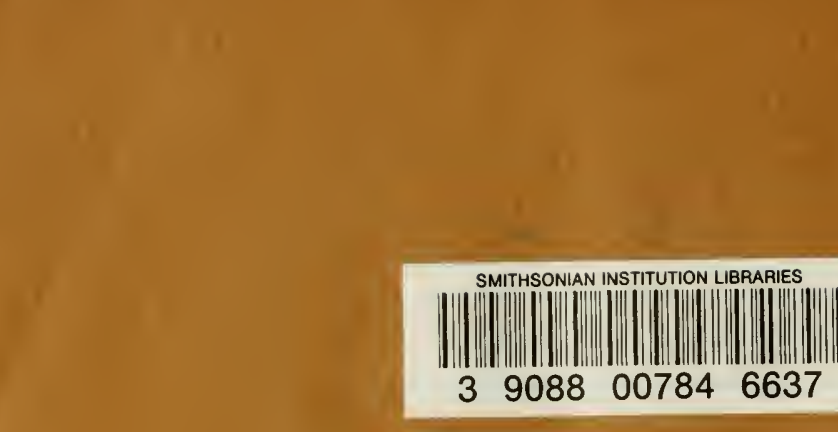

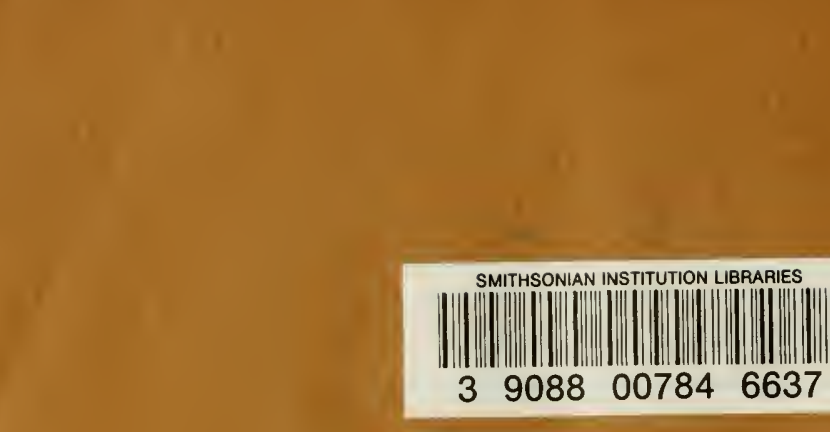

.

‥

. 